\title{
REATOR ANAERÓBIO EM BATELADA SEQÜENCIAL CONTENDO BIOMASSA IMOBILIZADA SUBMETIDO A AUMENTO DE CARGA ORGÂNICA TRATANDO ÁGUA RESIDUÁRIA SINTÉTICA
}

RENATO RIBEIRO SIMAN

Dissertação apresentada à Escola de Engenharia de São Carlos da Universidade de São Paulo como parte dos requisitos para obtenção do título de Mestre em Engenharia Hidráulica e Saneamento.

Orientador: Prof. Dr. José Alberto Domingues Rodrigues

São Carlos 
Candidato: Engenheiro RENATO RIBEIRO SIMAN

Dissertação defendida e julgada em 07-04-2003 perante a Comissão Julgadora:

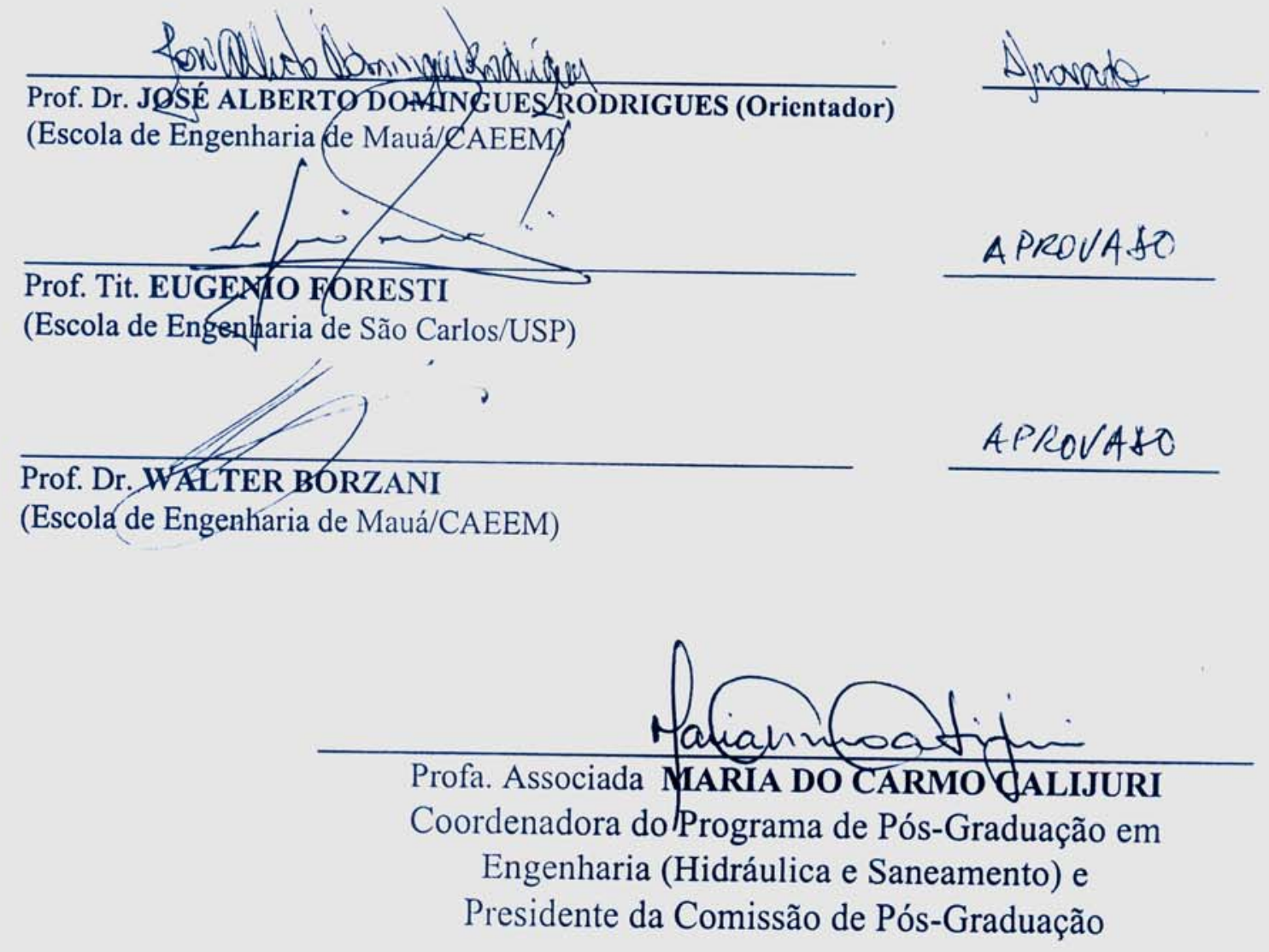




\section{DEDICATÓRIA}

À minha madrinha e avó Sedipe, que descanse em paz!

À minha família e a meus amigos que tanto me apoiaram nesse difícil momento. 


\section{COMO NASCE UM PARADIGMA}

Um grupo de cientistas colocou cinco macacos numa jaula, em cujo centro puseram uma escada e, sobre ela, um cacho de bananas. Quando um macaco subia a escada para apanhar as bananas, os cientistas lançavam um jato de água fria nos que estavam no chão. Depois de certo tempo, quando um macaco ia subir a escada, os outros enchiam-no de pancadas.

Passados mais algum tempo, nenhum macaco subia a escada, apesar da tentação das bananas. Então, os cientistas substituíram um dos cinco macacos. A primeira coisa que ele fez foi subir nas escadas, dela sendo rapidamente retirado pelos outros, que o surraram. Depois de algumas surras, o novo integrante do grupo não mais subia a escada. Um segundo foi substituído, e o mesmo ocorreu, tendo o primeiro substituto participado, com entusiasmo, da surra ao novato. Um terceiro foi trocado, e repetiu-se o fato. Um quarto e, finalmente, o último dos veteranos foi substituído. Os cientistas ficaram, então, com um grupo de cinco macacos que, mesmo nunca tendo tomado um banho frio, continuavam batendo naquele que tentasse chegar às bananas.

Se fosse possível perguntar a algum deles porque batiam em quem tentasse subir a escada, com certeza a resposta seria: não sei, as coisas sempre foram assim por aqui...

TRISTES TEMPOS OS NOSSOS...

É MAIS FÁCIL DESINTEGRAR UM ÁTOMO DO QUE UM PRECONCEITO... 


\section{AGRADECIMENTOS}

A Deus, por ter iluminado a minha vida e ter colocado pessoas maravilhosas na minha no meu caminho.

À minha querida avó, Sedipe Barros Ribeiro, que não teve a chance de presenciar mais esta conquista, e a meu avô Antonio Ribeiro Filho por ter me ensinado, a sua maneira, alguns truques da vida. À minha querida mãe Maria Ângela Ribeiro Siman, a quem devo minha existência e quem sempre esteve ao meu lado, dando-me o exemplo para a vida. Ao meu querido pai Nagib de Oliveira Siman, por ter me dado a oportunidade de chegar aonde cheguei. E às minhas queridas Irmãs Daihane, Janisse e Nágila Ribeiro Siman, por terem me dado amor e carinho e um sobrinho, Igor. À minha Tia Dodora, por ser a pessoa iluminada por Deus. A todos os meus tios, tias e primos que sempre me deram apoio. Valeu tio Ivon.

À minha segunda família Laura e José Paulo e a seus filhos Ana Paula e Marquinhos, por terem me amado e tratado como filho nos momentos de indecisão e carência, eu os amo bastante.

A meus amigos de infância, dos quais nunca me separei: Fabrício, Anderson (Tatu), Eduardo (Dudão), Josiane, Fernando, Jairo, e ao super irmão de todas as horas, José Roberto vulgo BETÃO, essa é para você!

À grande família Rosa Regina, Denis, Cleison, Shirleine, amos muito vocês, obrigado pela confiança que sempre depositaram em mim.

Aos meus amigos da UFRRJ e do GRUPO DE CAPOIRA ANGOLINHA: Maradey, Tiago (Japa), Alexandre (Alê), Fábio, Veralú, Nina, Ana Marta, Fábio Careca, Jaqueline, Piá, Erica, Ricardo (Bola Sete) e a Fernanda. Desculpe-me a 
memória. E a meu grande Pai (na vida!), Isac (Mestre Angolinha) pelo incentivo e companheirismo.

Aos Grandes amigos da EESC/USP, prof. Marcelo Zaiat, prof. Maria do Carmo Calijuri, prof. Eugênio Foresti, aos colegas Jucélia, Patrícia, Paola, Simone, Cristiano, Marcelo, Ana Paula, Guilherme, João, André, amigos do LEB/EEM e Eloísa Pozzi Gianotti. Ao pessoal da capoeira de São Carlos, o super amigo Valmir e a gatíssima Maristela. E aos mais que amigos, Sérgio Brasil e Sérgio Siebra, sem vocês eu nada faria daqui de São Caetano do Sul, valeu meus irmãos.

Ao Dr. José Alberto Domingues Rodrigues, pela amizade, orientação e dedicação ao trabalho. Aos colegas de trabalho Suzana Maria Ratusznei, Roberto Bezerra e Rafael, meu muito obrigado. A Baltus C. Bonse, pela ajuda com o inglês. Ao Gregor Friedl pelo desenho no CAD.

À FAPESP pelo auxílio financeiro e pela bolsa de estudos concedida.

À Escola de Engenharia Mauá do Centro Universitário do Instituto Mauá de Tecnologia, por ter cedido o espaço para que a etapa experimental se realizasse. Ao prof Walter Brozani pela orientação e ao pessoal da oficina pela construção do reator.

A todos os colaboradores que por esquecimento ou falta de espaço não tiveram seus nomes registrados nessa seção. As pessoas que, cada um a sua maneira, contribuíram para a concretização deste sonho, minha sincera gratidão.

E por último, porém de grande valor, ao meu grande amigo Alisson Carraro Borges, por ter me ajudado no momento mais difícil da minha vida! Desejo-te toda a sorte do mundo, pois você a merece. Obrigado pelo apoio, companheirismo e pela amizade desmedida, sem você este trabalho não saía. 


\section{SUMÁRIO}

LISTA DE FIGURAS ............................................................................i

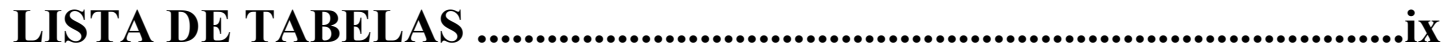

LISTA DE ABREVIATURAS E SIGLAS........................................xx

LISTA DE SÍMBOLOS .......................................................................

RESUMO ............................................................................................ Xxiv

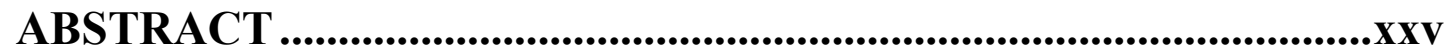

CAPÍTULO 1 -INTRODUÇÃO................................................................1

CAPÍTULO 2 - OBJETIVOS.......................................................................4

CAPÍTULO 3 - REVISÃO BIBLIOGRÁFICA .........................................5

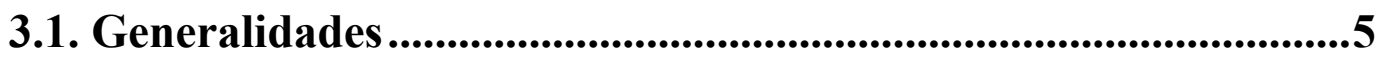

3.2. Retenção Microbiana em Reatores Anaeróbios..............................7

3.3. Fatores Ambientais na Digestão Anaeróbia ................................10 


\subsection{Reatores Anaeróbios Operados em Batelada Seqüencial}

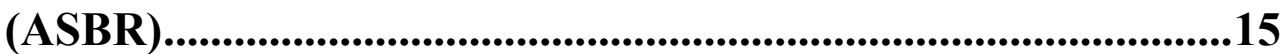

3.4.1. Histórico ..................................................................................................................... 15

3.4.2. Princípios Fundamentais ............................................................................ 16

3.4.3. Fatores que Afetam o Desempenho ............................................................. 17

3.4.4. Aplicações do Sistema ASBR ..................................................................... 19

3.5. Biomassa Imobilizada em Espuma de Poliuretano ......................28

3.6. Considerações Finais ...............................................................................30

CAPÍTULO 4 - MATERIAIS E MÉTODOS............................................32

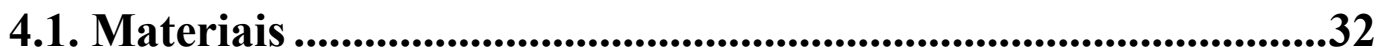

4.1.1. Configuração do Sistema ASBR com Biomassa Imobilizada ............. 32

4.1.2. Suporte de Imobilização da Biomassa Anaeróbia................................. 36

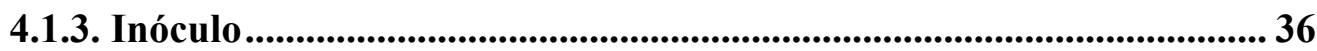

4.1.4.- Água Residuária Sintética................................................................ 37

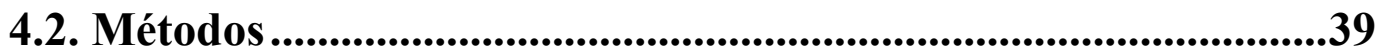

4.2.1. Composição do Biogás ................................................................................. 39

4.2.2. Análises Físico-Químicas....................................................................39

4.2.3. Análises Microbiológicas ...................................................................... 40

4.3. Procedimento Experimental ..................................................................41

4.3.1. Imobilização em Suporte Inerte.................................................................. 41 
4.3.2. Procedimento Operacional

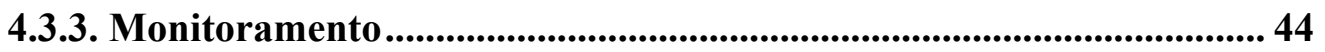

4.3.4.- Perfis das Variáveis Monitoradas ao Longo da Batelada ................ 45

4.3.5.- Análise de Sólidos na Espuma de Poliuretano....................................... 47

4.4. Fundamentos Teóricos ...........................................................................48

4.4.1. Parâmetros Operacionais ....................................................................... 48

4.4.2. Cálculo das Eficiências de Remoção.................................................. 51

4.4.3. Perfis de Conversão de Matéria Orgânica ao Longo da Batelada .... 53

CAPÍTULO 5 - RESULTADOS E DISCUSSÃO .....................................56

5.1. Concentração Afluente de 500 mgDQO/L e Ciclos de $8 \mathrm{~h} . . . . . . . . .56$

5.2. Concentração Afluente de 1000 mgDQO/L e Ciclos de $8 \mathrm{~h} . . . . . . .61$

5.3. Concentração Afluente de 2000 mgDQO/L e Ciclos de $8 \mathrm{~h}$........67

5.4. Concentração Afluente de 2000 mgDQO/L e Ciclos de $12 \mathrm{~h} . . . . .72$

5.5. Concentração Afluente de 1500 mgDQO/L e Ciclos de $12 \mathrm{~h}$.....76

5.6. Concentração Afluente de 1000 mgDQO/L e Ciclos de $12 \mathrm{~h}$.....81

5.7. Desempenho do ASBR Submetido a Diferentes Valores de $\mathrm{COV}$ .85

5.8. Perfis das Variáveis Monitoradas ao Longo da Batelada .........91

5.8.1. Perfil de Alcalinidade a Bicarbonato ...................................................91

5.8.2. Perfil de Concentração de Ácidos Voláteis ........................................... 92 
5.8.3. Perfil de Composição do Biogás. 93

5.8.4. Perfil de Remoção de Matéria Orgânica. 96

5.9. Análises Microbiologicas 104

CAPÍTULO 6 - CONCLUSÓES FINAIS 107

CAPÍTULO 7 - REFERÊNCIAS BIBLIOGRÁFICAS 110

APÊNDICE I - PROJETO DO REATOR ANAERÓBIO OPERADO EM BATELADA SEQÜENCIAL.

Vistas e cortes 119

APÊNDICE II - VARIÁVEIS MONITORADAS NO

AFLUENTE DO REATOR 124

APÊNDICE III - VARIÁVEIS MONITORADAS NO

EFLUENTE DO REATOR 135

APÊNDICE IV - PERFIL AO LONGO DA BATELADA 148 


\section{LISTA DE FIGURAS}

FIGURA 3.2- Representação das quatro fases de operação de um ASBR.Adaptado de DAGUE et al. (1992).

FIGURA 4.1- Esquema do reator anaeróbio operado em batelada seqüencial contendo biomassa imobilizada [Notação (cotas em milímetros)(1) Tanque de reação, (2) Substrato esterilizado, (3) Bomba de alimentação tipo diafragma, (4) Bomba de descarga tipo diafragma (5) Agitador mecânico, (6) Cesto de aço inoxidável contendo espumas com células imobilizadas, Temporizadores, (8) Efluente tratado e (9) Termômetro].....

FIGURA 4.2- Montagem experimental do ASBR com microrganismos imobilizados em cubos de espuma de poliuretano e tratando água residuária sintética

FIGURA 4.3- Reator montado mostrando detalhes do "head-space", do cesto e do impelidor.

FIGURA 4.4- A esquerda, cesto de aço inox 316 com tela, com $16 \mathrm{~cm}$ de altura e 19,5 cm de diâmetro (a) maior e 7 cm de diâmetro (b) menor; e a direita o impelidor tipo turbina com $6 \mathrm{~cm}$ de diâmetro, com 6 pás planas de $15 \times 15 \mathrm{~mm}$ de lado. 
FIGURA 4.5- Detalhe da dos cubos de espuma de poliuretano de $1 \mathrm{~cm}$ de lado (a) antes e (b) depois da inoculação com lodo.

FIGURA 5.1- Concentração de matéria orgânica efluente para amostras filtrada $\left(\mathrm{C}_{\mathrm{EF}}\right)$ e não filtrada $\left(\mathrm{C}_{\mathrm{ET}}\right)$, para condição de batelada de $8 \mathrm{~h}$ com alimentação de $500 \mathrm{mgDQO} / \mathrm{L}$

FIGURA 5.2- Eficiência de remoção de material orgânico para amostras filtrada $\left(\varepsilon_{\mathrm{EF}}\right)$ e não filtrada $\left(\varepsilon_{\mathrm{ET}}\right)$, para condição de batelada de $8 \mathrm{~h}$ com alimentação de $500 \mathrm{mgDQO} / \mathrm{L}$ .59

FIGURA 5.3- Alcalinidade a bicarbonato (AB) efluente e afluente, para condição de batelada de $8 \mathrm{~h}$ com alimentação de $500 \mathrm{mgDQO} / \mathrm{L}$ .60

FIGURA 5.4- Concentração de ácidos voláteis totais (AVT) efluente e afluente para condição de batelada de $8 \mathrm{~h}$ com alimentação de $500 \mathrm{mgDQO} / \mathrm{L}$

FIGURA 5.5- Concentração de matéria orgânica efluente para amostras filtradas $\left(\mathrm{C}_{\mathrm{EF}}\right)$ e não filtradas $\left(\mathrm{C}_{\mathrm{ET}}\right)$, para condição de batelada de $8 \mathrm{~h}$ com alimentação de $1000 \mathrm{mgDQO} / \mathrm{L}$

FIGURA 5.6- Eficiência de remoção de material orgânico para amostras filtradas $\left(\varepsilon_{\mathrm{EF}}\right)$ e não filtradas $\left(\varepsilon_{\mathrm{ET}}\right)$, para condição de batelada de $8 \mathrm{~h}$ com alimentação de $1000 \mathrm{mgDQO} / \mathrm{L}$.

FIGURA 5.7- Alcalinidade a bicarbonato (AB) efluente e afluente, para condição de batelada de 8 h com alimentação de $1000 \mathrm{mgDQO} / \mathrm{L}$. 
FIGURA 5.8- Concentração de ácidos voláteis totais (AVT) efluente e afluente, para condição de batelada de $8 \mathrm{~h}$ com alimentação de $1000 \mathrm{mgDQO} / \mathrm{L}$.

FIGURA 5.9- Concentração de matéria orgânica efluente para amostras filtrada $\left(\mathrm{C}_{\mathrm{EF}}\right)$ e não filtrada $\left(\mathrm{C}_{\mathrm{ET}}\right)$, para batelada de $8 \mathrm{~h}$ com alimentação de $2000 \mathrm{mgDQO} / \mathrm{L}$

Figura 5.10- Eficiência de remoção de material orgânico para amostras filtrada $\left(\varepsilon_{\mathrm{EF}}\right)$ e não filtrada $\left(\varepsilon_{\mathrm{ET}}\right)$, para batelada de $8 \mathrm{~h}$ com alimentação de 2000 mgDQO/L. . .70

FIGURA 5.11- Alcalinidade a bicarbonato (AB) efluente e afluente, para batelada de $8 \mathrm{~h}$ com alimentação de 2000 mgDQO/L

FIGURA 5.12- Concentração de ácidos voláteis totais (AVT) efluente e afluente, para batelada de $8 \mathrm{~h}$ com alimentação de $2000 \mathrm{mgDQO} / \mathrm{L}$

FIGURA 5.13- Concentração de matéria orgânica efluente para amostras filtrada $\left(\mathrm{C}_{\mathrm{EF}}\right)$ e não filtrada $\left(\mathrm{C}_{\mathrm{ET}}\right)$, para batelada de $12 \mathrm{~h}$ com alimentação de $2000 \mathrm{mgDQO} / \mathrm{L}$

FIGURA 5.14- Eficiência de remoção de material orgânico para amostras filtrada $\left(\varepsilon_{\mathrm{EF}}\right)$ e não filtrada $\left(\varepsilon_{\mathrm{ET}}\right)$, para batelada de $12 \mathrm{~h}$ com alimentação de 2000 mgDQO/L.

FIGURA 5.15- Alcalinidade a bicarbonato (AB) efluente e afluente, para batelada de 12 h com alimentação 2000 mgDQO/L 
FIGURA 5.16- Concentração de ácidos voláteis totais (AVT) efluente e afluente, para batelada de $12 \mathrm{~h}$ com alimentação de $2000 \mathrm{mgDQO} / \mathrm{L}$.

FIGURA 5.17- Concentração de matéria orgânica efluente para amostras filtrada $\left(\mathrm{C}_{\mathrm{EF}}\right)$ e não filtrada $\left(\mathrm{C}_{\mathrm{ET}}\right)$, para batelada de $12 \mathrm{~h}$ com alimentação de $1500 \mathrm{mgDQO} / \mathrm{L}$ .79

Figura 5.18- Eficiência de remoção de material orgânico para amostras filtrada $\left(\varepsilon_{\mathrm{EF}}\right)$ e não filtrada $\left(\varepsilon_{\mathrm{ET}}\right)$, para batelada de $12 \mathrm{~h}$ com alimentação de 1500 mgDQO/L. .79

FIGURA 5.19- Alcalinidade a bicarbonato (AB) efluente e afluente, para batelada de $12 \mathrm{~h}$ com alimentação $1500 \mathrm{mgDQO} / \mathrm{L}$

FIGURA 5.20- Concentração de ácidos voláteis totais (AVT) efluente e afluente, para batelada de $12 \mathrm{~h}$ com alimentação de $1500 \mathrm{mgDQO} / \mathrm{L}$. .80

FIGURA 5.21- Concentração de matéria orgânica efluente para amostras filtrada $\left(\mathrm{C}_{\mathrm{EF}}\right)$ e não filtrada $\left(\mathrm{C}_{\mathrm{ET}}\right)$, para batelada de $12 \mathrm{~h}$ com alimentação de $1000 \mathrm{mgDQO} / \mathrm{L}$ .83

Figura 5.22- Eficiência de remoção de material orgânico para amostras filtrada $\left(\varepsilon_{\mathrm{EF}}\right)$ e não filtrada $\left(\varepsilon_{\mathrm{ET}}\right)$, para batelada de $12 \mathrm{~h}$ com alimentação de $1000 \mathrm{mgDQO} / \mathrm{L}$.

FIGURA 5.23- Alcalinidade a bicarbonato (AB) efluente e afluente, para batelada de 12 h com alimentação 1000 mgDQO/L .84

FIGURA 5.24- Concentração de ácidos voláteis totais (AVT) efluente e afluente, para batelada de $12 \mathrm{~h}$ com alimentação de $1000 \mathrm{mgDQO} / \mathrm{L}$. 
FIGURA 5.25- Concentrações de matéria orgânica efluente para as condições operacionais. Bateladas de $8 \mathrm{~h}$ e concentrações afluentes de (I) $500 \mathrm{mgDQO} / \mathrm{L}$, (II) $1000 \mathrm{mgDQO} / \mathrm{L}$, (III) $2000 \mathrm{mgDQO} / \mathrm{L}$. Bateladas de 12 h e concentrações afluentes de (IV) $2000 \mathrm{mgDQO} / \mathrm{L}$, (V) $1500 \mathrm{mgDQO} / \mathrm{L}$ e (VI) $1000 \mathrm{mgDQO} / \mathrm{L}$

FIGURA 5.26- Concentrações de alcalinidade a bicarbonato para as condições operacionais. Bateladas de 8 h e concentrações afluentes de (I) $500 \mathrm{mgDQO} / \mathrm{L}$, (II) $1000 \mathrm{mgDQO} / \mathrm{L}$, (III) $2000 \mathrm{mgDQO} / \mathrm{L}$. Bateladas de 12 h e concentrações afluentes de (IV) $2000 \mathrm{mgDQO} / \mathrm{L}$, (V) $1500 \mathrm{mgDQO} / \mathrm{L} \mathrm{e}$ (VI) $1000 \mathrm{mgDQO} / \mathrm{L}$

FIGURA 5.27- Concentrações de ácidos voláteis totais para as condições operacionais. Bateladas de 8 h e concentrações afluentes de (I) $500 \mathrm{mgDQO} / \mathrm{L}$, (II) $1000 \mathrm{mgDQO} / \mathrm{L}$, (III) $2000 \mathrm{mgDQO} / \mathrm{L}$. Bateladas de 12 h e concentrações afluentes de (IV) $2000 \mathrm{mgDQO} / \mathrm{L},(\mathrm{V}) 1500 \mathrm{mgDQO} / \mathrm{L} \mathrm{e}$ (VI) $1000 \mathrm{mgDQO} / \mathrm{L}$ .90

FIGURA 5.28- Perfis médios de alcalinidade a bicarbonato. Bateladas de $8 \mathrm{~h} \mathrm{e}$ concentrações afluentes de (I) $500 \mathrm{mgDQO} / \mathrm{L}$, $1000 \mathrm{mgDQO} / \mathrm{L}$, (III) $2000 \mathrm{mgDQO} / \mathrm{L}$. Bateladas de $12 \mathrm{~h} \mathrm{e}$ concentrações afluentes de (IV) 2000 mgDQO/L, (V) $1500 \mathrm{mgDQO} / \mathrm{L} \mathrm{e}(\mathrm{VI}) 1000 \mathrm{mgDQO} / \mathrm{L}$

FIGURA 5.29- Perfis médios da concentração de ácidos voláteis totais. Bateladas de 8 h e concentrações afluentes de(I) $500 \mathrm{mgDQO} / \mathrm{L}$, (II) 1000 mgDQO/L, (III) 2000 mgDQO/L. Bateladas de $12 \mathrm{~h} \mathrm{e}$ 
concentrações afluentes de (IV) 2000 mgDQO/L, (V) $1500 \mathrm{mgDQO} / \mathrm{L} \mathrm{e}(\mathrm{VI}) 1000 \mathrm{mgDQO} / \mathrm{L}$

FIGURA 5.30- Perfis médios das concentrações de metano. Bateladas de $8 \mathrm{~h}$ e concentrações afluentes de (II) 1000 mgDQO/L, (III) $2000 \mathrm{mgDQO} / \mathrm{L}$. Bateladas de $12 \mathrm{~h}$ e concentrações afluentes de (IV) $2000 \mathrm{mgDQO} / \mathrm{L}, \quad$ (V) $1500 \quad \mathrm{mgDQO} / \mathrm{L} \quad \mathrm{e} \quad$ (VI) $1000 \mathrm{mgDQO} / \mathrm{L}$

FIGURA 5.31- Perfis médios da concentração de dióxido de carbono. Bateladas de $8 \mathrm{~h}$ e concentrações afluentes de (II) $1000 \mathrm{mgDQO} / \mathrm{L}$, (III) $2000 \mathrm{mgDQO} / \mathrm{L}$. Bateladas de $12 \mathrm{~h}$ e concentrações afluentes de (IV) $2000 \mathrm{mgDQO} / \mathrm{L}, \quad$ (V) $1500 \quad \mathrm{mgDQO} / \mathrm{L} \quad \mathrm{e} \quad$ (VI) $1000 \mathrm{mgDQO} / \mathrm{L}$. .95

FIGURA 5.32- Perfis médios das frações molares de metano. Bateladas de $8 \mathrm{~h} \mathrm{e}$ concentrações afluentes de (II) $1000 \mathrm{mgDQO} / \mathrm{L}$, (III) $2000 \mathrm{mgDQO} / \mathrm{L}$. Bateladas de $12 \mathrm{~h}$ e concentrações afluentes de (IV) $2000 \quad \mathrm{mgDQO} / \mathrm{L}, \quad$ (V) $1500 \quad \mathrm{mgDQO} / \mathrm{L} \quad$ e $\quad$ (VI) $1000 \mathrm{mgDQO} / \mathrm{L}$

FIGURA 5.33- Perfis médios das frações molares de dióxido de carbono. Bateladas de $8 \mathrm{~h}$ e concentrações afluentes de (II) $1000 \mathrm{mgDQO} / \mathrm{L}$, (III) $2000 \mathrm{mgDQO} / \mathrm{L}$. Bateladas de $12 \mathrm{~h} \mathrm{e}$ concentrações afluentes de (IV) 2000 mgDQO/L, (V) $1500 \mathrm{mgDQO} / \mathrm{L}$ e (VI) $1000 \mathrm{mgDQO} / \mathrm{L}$ 
FIGURA 5.34- -Perfis médios de material orgânico efluente para amostras filtradas. Bateladas de $8 \mathrm{~h}$ e concentrações afluentes de (I) 500 mgDQO/L, (II) $1000 \quad \mathrm{mgDQO} / \mathrm{L}, \quad$ (III) $2000 \quad \mathrm{mgDQO} / \mathrm{L}$. Bateladas de $12 \mathrm{~h}$ e concentrações afluentes de (IV) 2000 mgDQO/L, (V) 1500 mgDQO/L e (VI) 1000 mgDQO/L

FIGURA 5.35- Ajuste do modelo de cinético de primeira ordem aos valores experimentais. Condição de alimentação com concentração afluente de $500 \mathrm{mgDQO} / \mathrm{L}$ em bateladas de $8 \mathrm{~h}$. (a) $\mathrm{C}_{\mathrm{So}}$ e $\mathrm{C}_{\mathrm{SR}}$ constantes e (b) $\mathrm{C}_{\mathrm{So}}$ constante e $\mathrm{C}_{\mathrm{SR}}$ como variável. .99

FIGURA 5.36- Ajuste do modelo de cinético de primeira ordem aos valores experimentais. Condição de alimentação com concentração afluente de $1000 \mathrm{mgDQO} / \mathrm{L}$ em bateladas de $8 \mathrm{~h}$. (a) $\mathrm{C}_{\mathrm{So}}$ e $\mathrm{C}_{\mathrm{SR}}$ constantes e (b) $\mathrm{C}_{\mathrm{So}}$ constante e $\mathrm{C}_{\mathrm{SR}}$ como variável. .99

FIGURA 5.37- Ajuste do modelo de cinético de primeira ordem aos valores experimentais. Condição de alimentação com concentração afluente de $2000 \mathrm{mgDQO} / \mathrm{L}$ em bateladas de $8 \mathrm{~h}$. (a) $\mathrm{C}_{\mathrm{So}}$ e $\mathrm{C}_{\mathrm{SR}}$ constantes e (b) $\mathrm{C}_{\mathrm{So}}$ constante e $\mathrm{C}_{\mathrm{SR}}$ como variável.

FIGURA 5.38- Ajuste do modelo de cinético de primeira ordem aos valores experimentais. Condição de alimentação com concentração afluente de $2000 \mathrm{mgDQO} / \mathrm{L}$ em bateladas de $12 \mathrm{~h}$. (a) $\mathrm{C}_{\mathrm{So}}$ e $\mathrm{C}_{\mathrm{SR}}$ constantes e (b) $\mathrm{C}_{\mathrm{So}}$ constante e $\mathrm{C}_{\mathrm{SR}}$ como variável. 100

FIGURA 5.39- Ajuste do modelo de cinético de primeira ordem aos valores experimentais. Condição de alimentação com concentração 
afluente de $1500 \mathrm{mgDQO} / \mathrm{L}$ em bateladas de $12 \mathrm{~h}$. (a) $\mathrm{C}_{\mathrm{So}}$ e $\mathrm{C}_{\mathrm{SR}}$ constantes e (b) $\mathrm{C}_{\mathrm{So}}$ constante e $\mathrm{C}_{\mathrm{SR}}$ como variável.

FIGURA 5.40- Ajuste do modelo de cinético de primeira ordem aos valores experimentais. Condição de alimentação com concentração afluente de $1000 \mathrm{mgDQO} / \mathrm{L}$ em bateladas de $12 \mathrm{~h}$. (a) $\mathrm{C}_{\mathrm{So}}$ e CSR constantes e (b) $\mathrm{C}_{\mathrm{So}}$ constante e $\mathrm{C}_{\mathrm{SR}}$ como variável.

FIGURA 5.41- Morfologias microbiana por microscopia ótica de contraste de fases. Células semelhantes a bacilos hidrogenotróficos.

FIGURA 5.42- Morfologias microbiana por microscopia ótica comum. Células semelhantes a Methanoarcina sp.

FIGURA 5.43- Morfologias microbiana por microscopia ótica de contraste de fases. Células semelhantes a Methanoarcina sp.

FIGURA 5.44- Morfologias microbiana por microscopia ótica comum. Filamentos semelhantes a Methanosaeta sp e víbrios.. 106

FIGURA I.1- Vista superior do reator anaeróbio operado em batelada seqüencial. ESCALA 1:3.

FIGURA I.2- Vista frontal do reator anaeróbio operado em batelada seqüencial. ESCALA 1:3.

FIGURA I.3- Reator anaeróbio operado em batelada seqüencial. Corte A. ESCALA 1:3.

FIGURA I.4- Reator anaeróbio operado em batelada seqüencial. Corte B. ESCALA 1:3. 


\section{LISTA DE TABELAS}

TABELA 4.1- Descrição da água residuária utilizada (TORRES, 1992).................38

TABELA 4.2- Composição da água residuária utilizada (TORRES, 1992)..............38

TABELA 4.3- Condições operacionais implementadas para estudo de aumento de carga orgânica volumétrica.

TABELA 4.4- Freqüência dos parâmetros analisados durante os ciclos operacionais para as três primeiras condições operacionais.

TABELA 5.1- Variáveis monitoradas no ensaio do ASBR com biomassa imobilizada, operado em batelada de $8 \mathrm{~h}$ com alimentação de $500 \mathrm{mgDQO} / \mathrm{L}$.

TABELA 5.2- Parâmetros operacionais para a primeira condição operacional. .58

TABELA 5.3- Variáveis monitoradas no ensaio do ASBR com biomassa imobilizada, operado em batelada de $8 \mathrm{~h}$ com alimentação de $1000 \mathrm{mgDQO} / \mathrm{L}$.

TABELA 5.4- Parâmetros operacionais para a segunda condição operacional. .63

TABELA 5.5- Variáveis monitoradas no ensaio do ASBR com biomassa imobilizada, operado em batelada de $8 \mathrm{~h}$ com alimentação de $2000 \mathrm{mgDQO} / \mathrm{L}$. .68

TABELA 5.6- Parâmetros operacionais para a terceira condição operacional. .69 
TABELA 5.7- Variáveis monitoradas no ensaio do ASBR com biomassa imobilizada, operado em batelada de 12 h com alimentação de $2000 \mathrm{mgDQO} / \mathrm{L}$.

TABELA 5.8- Parâmetros operacionais para a quarta condição operacional. .74

TABELA 5.9- Variáveis monitoradas no ensaio do ASBR com biomassa imobilizada, operado com batelada de $12 \mathrm{~h}$ com alimentação de $1500 \mathrm{mgDQO} / \mathrm{L}$.

TABELA 5.10- Parâmetros operacionais calculados para a quinta condição operacional. .78

TABELA 5.11- Variáveis monitoradas no ensaio do ASBR com biomassa imobilizada, operado com batelada de $12 \mathrm{~h}$ com alimentação de $1000 \mathrm{mgDQO} / \mathrm{L}$.

TABELA 5.12- Parâmetros operacionais calculados para a sexta condição operacional.

TABELA 5.13- Valores médios das concentrações de material orgânico para amostras afluentes e efluentes, eficiência de remoção de material orgânico para amostras filtradas e volume médio descarregado por batelada para todas as condições aplicadas.

TABELA 5.14- Valores médios de alcalinidades a bicarbonato, concentração de ácidos voláteis totais e relação $\mathrm{AI} / \mathrm{AP}$ para afluente e efluente, em todas as condições estudadas. 
TABELA 5.15- Valores obtidos para a constante cinética específica aparente $\left(\mathrm{k}_{1}\right)$, calculada pelo ajuste do modelo cinético de primeira ordem aos valores experimentais.

TABELA II.1 - Concentração de substrato $\left(\mathrm{C}_{\mathrm{A}}\right), \mathrm{pH}$, alcalinidade parcial (AP), alcalinidade intermediária (AI), alcalinidade total (AT), relação entre as alcalinidades intermediária e total (AI/AP), alcalinidade a bicarbonato $(\mathrm{AB})$ e concentração de ácidos voláteis totais (AVT) da água residuária na concentração de $500 \mathrm{mgDQO} / \mathrm{L}$

TABELA II.2- Sólidos da água residuária na concentração de 500 mgDQO/L

TABELA II.3- Concentração de substrato $\left(\mathrm{C}_{\mathrm{A}}\right), \mathrm{pH}$, alcalinidade parcial (AP), alcalinidade intermediária (AI), alcalinidade total (AT), relação entre as alcalinidades intermediária e total (AI/AP), alcalinidade a bicarbonato $(\mathrm{AB})$ e concentração de ácidos voláteis totais (AVT) da água residuária na concentração de $1000 \mathrm{mgDQO} / \mathrm{L}$

TABELA II.4- Sólidos da água residuária na concentração de $1000 \mathrm{mgDQO} / \mathrm{L}$

TABELA II.5- Concentração de substrato $\left(\mathrm{C}_{\mathrm{A}}\right), \mathrm{pH}$, alcalinidade parcial (AP), alcalinidade intermediária (AI), alcalinidade total (AT), relação entre as alcalinidades intermediária e total (AI/AP), alcalinidade a bicarbonato $(\mathrm{AB})$ e concentração de ácidos 
voláteis totais (AVT) da água residuária na concentração de $2000 \mathrm{mgDQO} / \mathrm{L}$

TABELA II.6- Sólidos da água residuária na concentração de $2000 \mathrm{mgDQO} / \mathrm{L}$

TABELA II.7- Concentração de substrato $\left(\mathrm{C}_{\mathrm{A}}\right), \mathrm{pH}$, alcalinidade parcial (AP), alcalinidade intermediária (AI), alcalinidade total (AT), relação entre as alcalinidades intermediária e total (AI/AP), alcalinidade a bicarbonato $(\mathrm{AB})$ e concentração de ácidos voláteis totais (AVT) da água residuária na concentração de $2000 \mathrm{mgDQO} / \mathrm{L}$

TABELA II.8- Sólidos da água residuária na concentração de $2000 \mathrm{mgDQO} / \mathrm{L}$. 130

TABELA II.9- Concentração de substrato $\left(\mathrm{C}_{\mathrm{A}}\right), \mathrm{pH}$, alcalinidade parcial (AP), alcalinidade intermediária (AI), alcalinidade total (AT), relação entre as alcalinidades intermediária e total (AI/AP), alcalinidade a bicarbonato $(\mathrm{AB})$ e concentração de ácidos voláteis totais (AVT) da água residuária na concentração de $1500 \mathrm{mgDQO} / \mathrm{L}$

TABELA II.10- Sólidos da água residuária na concentração de $1500 \mathrm{mgDQO} / \mathrm{L}$

TABELA II.11- Concentração de substrato $\left(\mathrm{C}_{\mathrm{A}}\right), \mathrm{pH}$, alcalinidade parcial (AP), alcalinidade intermediária (AI), alcalinidade total (AT), relação entre as alcalinidades intermediária e total (AI/AP), 
alcalinidade a bicarbonato $(\mathrm{AB})$ e concentração de ácidos voláteis totais (AVT) da água residuária na concentração de $1000 \mathrm{mgDQO} / \mathrm{L}$

TABELA II.12- Sólidos da água residuária na concentração de $1000 \mathrm{mgDQO} / \mathrm{L}$

TABELA III.1- Concentração de substrato filtrado e não filtrado( $C_{E F}$ e $\left.C_{E T}\right)$, remoção de matéria orgânica filtrada e não filtrada( $\varepsilon_{\mathrm{EF}}$ e $\left.\varepsilon_{\mathrm{ET}}\right)$, $\mathrm{pH}$, alcalinidade parcial (AP), alcalinidade intermediária (AI), alcalinidade total (AT), relação entre as alcalinidades intermediária e parcial (AI/AP), alcalinidade a bicarbonato (AB) e concentração de ácidos voláteis totais (AVT) do efluente para condição de operação com batelada de $8 \mathrm{~h} \mathrm{e}$ alimentação de 500 mgDQO/L.

TABELA III.2- Sólidos efluentes para condição de operação com batelada de $8 \mathrm{~h}$ e alimentação de $500 \mathrm{mgDQO} / \mathrm{L}$

TABELA III.3- Concentração de substrato filtrado e não filtrado( $C_{E F}$ e $\left.C_{E T}\right)$, remoção de matéria orgânica filtrada e não filtrada $\left(\varepsilon_{\mathrm{EF}}\right.$ e $\left.\varepsilon_{\mathrm{ET}}\right)$, $\mathrm{pH}$, alcalinidade parcial (AP), alcalinidade intermediária (AI), alcalinidade total (AT), relação entre as alcalinidades intermediária e parcial (AI/AP), alcalinidade a bicarbonato (AB) e concentração de ácidos voláteis totais (AVT) do 
efluente para condição de operação com batelada de $8 \mathrm{~h}$ e alimentação de 500 mgDQO/L.

TABELA III.4- Sólidos efluentes para condição de operação com batelada de 8 h e alimentação de 1000 mgDQO/L

TABELA III.5- Concentração de substrato filtrado e não filtrado $\left(C_{E F}\right.$ e $\left.C_{E T}\right)$, remoção de matéria orgânica filtrada e não filtrada $\left(\varepsilon_{\mathrm{EF}}\right.$ e $\left.\varepsilon_{\mathrm{ET}}\right)$, $\mathrm{pH}$, alcalinidade parcial (AP), alcalinidade intermediária (AI), alcalinidade total (AT), relação entre as alcalinidades intermediária e parcial (AI/AP), alcalinidade a bicarbonato (AB) e concentração de ácidos voláteis totais (AVT) do efluente para condição de operação com batelada de $8 \mathrm{~h}$ e alimentação de 2000 mgDQO/L

TABELA III.6- Sólidos efluentes para condição de operação com batelada de 8 h e alimentação de 2000 mgDQO/L

TABELA III.7- Concentração de substrato filtrado e não filtrado $\left(\mathrm{C}_{\mathrm{EF}}\right.$ e $\left.\mathrm{C}_{\mathrm{ET}}\right)$, remoção de matéria orgânica filtrada e não filtrada $\left(\varepsilon_{\mathrm{EF}}\right.$ e $\left.\varepsilon_{\mathrm{ET}}\right)$, $\mathrm{pH}$, alcalinidade parcial (AP), alcalinidade intermediária (AI), alcalinidade total (AT), relação entre as alcalinidades intermediária e parcial (AI/AP), alcalinidade a bicarbonato (AB) e concentração de ácidos voláteis totais (AVT) do efluente para condição de operação com batelada de $12 \mathrm{~h}$ e alimentação de $2000 \mathrm{mgDQO} / \mathrm{L}$ 
TABELA III.8- Sólidos efluentes para condição de operação com batelada de 12 h e alimentação de 2000 mgDQO/L

TABELA III.9- Concentração de substrato filtrado e não filtrado $\left(C_{E F}\right.$ e $\left.C_{E T}\right)$, remoção de matéria orgânica filtrada e não filtrada $\left(\varepsilon_{\mathrm{EF}}\right.$ e $\left.\varepsilon_{\mathrm{ET}}\right)$, $\mathrm{pH}$, alcalinidade parcial (AP), alcalinidade intermediária (AI), alcalinidade total (AT), relação entre as alcalinidades intermediária e parcial (AI/AP), alcalinidade a bicarbonato (AB) e concentração de ácidos voláteis totais (AVT) do efluente para condição de operação com batelada de $12 \mathrm{~h}$ e alimentação de $1500 \mathrm{mgDQO} / \mathrm{L}$

TABELA III.10- Sólidos efluentes para condição de operação com batelada de 12 h e alimentação de $1500 \mathrm{mgDQO} / \mathrm{L}$ 145

TABELA III.11- Concentração de substrato filtrado e não filtrado $\left(\mathrm{C}_{\mathrm{EF}}\right.$ e $\left.\mathrm{C}_{\mathrm{ET}}\right)$, remoção de matéria orgânica filtrada e não filtrada $\left(\varepsilon_{\mathrm{EF}}\right.$ e $\left.\varepsilon_{\mathrm{ET}}\right)$, $\mathrm{pH}$, alcalinidade parcial (AP), alcalinidade intermediária (AI), alcalinidade total (AT), relação entre as alcalinidades intermediária e parcial (AI/AP), alcalinidade a bicarbonato (AB) e concentração de ácidos voláteis totais (AVT) do efluente para condição de operação com batelada de $12 \mathrm{~h}$ e alimentação de 1000 mgDQO/L.

TABELA III.12- Sólidos efluentes para condição de operação com batelada de $12 \mathrm{~h}$ e alimentação de 1000 mgDQO/L 
TABELA IV.1- Perfil de concentração de substrato filtrado $\left(\mathrm{C}_{\mathrm{EFi}}\right)$, eficiências de remoção para o perfil $\left(\varepsilon_{\mathrm{Pi}}\right)$, concentrações de substrato corrigidas $\left(\mathrm{C}_{\mathrm{EFi}}\right)$ e respectivas médias do efluente para condição de operação com batelada de $8 \mathrm{~h}$ e alimentação de $500 \mathrm{mgDQO} / \mathrm{L}$

TABELA IV.2- Perfis de concentração de alcalinidade a bicarbonato (AB) e concentração de ácidos voláteis totais (AVT) ao longo do ciclo do efluente para condição de operação com batelada de $8 \mathrm{~h}$ e alimentação de 500 mgDQO/L.

TABELA IV.3- Perfil de concentração de substrato filtrado $\left(\mathrm{C}_{\mathrm{EFi}}\right)$, eficiências de remoção para o perfil $\left(\varepsilon_{\mathrm{Pi}}\right)$, concentrações de substrato corrigidas $\left(\mathrm{C}_{\mathrm{EFi}}^{\prime}\right)$ e respectivas médias do efluente para condição de operação com batelada de $8 \mathrm{~h}$ e alimentação de $1000 \mathrm{mgDQO} / \mathrm{L}$

TABELA IV.4- Perfis de concentração de alcalinidade a bicarbonato (AB) e concentração de ácidos voláteis totais (AVT) ao longo do ciclo do efluente para condição de operação com batelada de $8 \mathrm{~h} \mathrm{e}$ alimentação de 1000 mgDQO/L

TABELA IV.5- Perfil de composição do biogás ao longo do ciclo do efluente para condição de operação com batelada de 8 h e alimentação de $1000 \mathrm{mgDQO} / \mathrm{L}$ 
TABELA IV.6- Perfil de fração molar do biogás ao longo do ciclo do efluente para condição de operação com batelada de 8 h e alimentação de $1000 \mathrm{mgDQO} / \mathrm{L}$

TABELA IV.7- Perfil de concentração de substrato filtrado $\left(\mathrm{C}_{\mathrm{EF}}\right)$, eficiências de remoção para o perfil $\left(\varepsilon_{\mathrm{P}}\right)$ no perfil ao longo do ciclo para condição de operação com batelada de $8 \mathrm{~h}$ e alimentação de $2000 \mathrm{mgDQO} / \mathrm{L}$.

TABELA IV.8- Perfis de concentração de alcalinidade a bicarbonato (AB) e concentração de ácidos voláteis totais (AVT) ao longo do ciclo para condição de operação com batelada de 8 h e alimentação de $2000 \mathrm{mgDQO} / \mathrm{L}$ 156

TABELA IV.9- Perfil de composição do biogás ao longo do ciclo para condição de operação com batelada de 8 h e alimentação de $2000 \mathrm{mgDQO} / \mathrm{L}$.

TABELA IV.10- Perfil de fração molar do biogás ao longo do ciclo para condição de operação com batelada de $8 \mathrm{~h}$ e alimentação de $2000 \mathrm{mgDQO} / \mathrm{L}$

TABELA IV.11 - Perfil de concentração de substrato filtrado $\left(\mathrm{C}_{\mathrm{EFi}}\right)$, eficiências de remoção para o perfil $\left(\varepsilon_{\mathrm{Pi}}\right)$, concentrações de substrato corrigidas $\left(\mathrm{C}^{\prime}{ }_{\mathrm{EFi}}\right)$ e respectivas médias do efluente para condição de operação com batelada de $12 \mathrm{~h}$ e alimentação de $2000 \mathrm{mgDQO} / \mathrm{L}$ 
TABELA IV.12- Perfis de concentração de alcalinidade a bicarbonato (AB) e concentração de ácidos voláteis totais (AVT) ao longo do ciclo do efluente para condição de operação com batelada de $12 \mathrm{~h}$ e alimentação de 2000 mgDQO/L

TABELA IV.13- Perfil de composição do biogás ao longo do ciclo do efluente para condição de operação com batelada de 12 h e alimentação de $2000 \mathrm{mgDQO} / \mathrm{L}$

TABELA IV.14- Perfil de fração molar do biogás ao longo do ciclo do efluente para condição de operação com batelada de 12 h e alimentação de 2000mgDQO/L

TABELA IV.15- Perfil de concentração de substrato filtrado $\left(\mathrm{C}_{\mathrm{EFi}}\right)$, eficiências de remoção para o perfil $\left(\varepsilon_{\mathrm{Pi}}\right)$, concentrações de substrato corrigidas $\left(\mathrm{C}^{\prime}{ }_{\mathrm{EFi}}\right)$ e respectivas médias do efluente para condição de operação com batelada de 12 h e alimentação de $1500 \mathrm{mgDQO} / \mathrm{L}$

TABELA IV.16- Perfis de concentração de alcalinidade a bicarbonato (AB) e concentração de ácidos voláteis totais (AVT) ao longo do ciclo do efluente para condição de operação com batelada de $12 \mathrm{~h} \mathrm{e}$ alimentação de $1500 \mathrm{mgDQO} / \mathrm{L}$.

TABELA IV.17- Perfil de composição do biogás ao longo do ciclo para condição de operação com batelada de 12 h e alimentação de $1500 \mathrm{mgDQO} / \mathrm{L}$ 
TABELA IV.18- Perfil de fração molar do biogás ao longo do ciclo para condição de operação com batelada de $12 \mathrm{~h}$ e alimentação de $1500 \mathrm{mgDQO} / \mathrm{L}$

TABELA IV.19- Perfil de concentração de substrato filtrado $\left(\mathrm{C}_{\mathrm{EFi}}\right)$, eficiências de remoção para o perfil $\left(\varepsilon_{\mathrm{Pi}}\right)$, concentrações de substrato corrigidas $\left(\mathrm{C}^{\prime}{ }_{\mathrm{EFi}}\right)$ e respectivas médias do efluente para condição de operação com batelada de 12 h e alimentação de $1000 \mathrm{mgDQO} / \mathrm{L}$

TABELA IV.20- Perfis de concentração de alcalinidade a bicarbonato (AB) e concentração de ácidos voláteis totais (AVT) ao longo do ciclo do efluente para condição de operação com batelada de 12 h e alimentação de 1000 mgDQO/L

TABELA IV.21- Perfil de composição do biogás ao longo do ciclo do efluente para condição de operação com batelada de 12 h e alimentação de $1000 \mathrm{mgDQO} / \mathrm{L}$

TABELA IV.22- Perfil de fração molar do biogás ao longo do ciclo do efluente para condição de operação com batelada de 12 h e alimentação de $1000 \mathrm{mgDQO} / \mathrm{L}$ 


\title{
LISTA DE ABREVIATURAS E SIGLAS
}

\author{
ASBR Reator Anaeróbio Operado em Batelada Seqüencial (Anaerobic \\ Sequencing Batch Reactor); \\ DQO Demanda Química de Oxigênio; \\ FAPESP $\quad$ Fundação de Amparo à Pesquisa do Estado de São Paulo; \\ RNAr Análise de Ácido Ribonucléico ribossomal; \\ UASB Reator Anaeróbio de Fluxo Ascendente e Manta de Lodo (Upflow \\ Anaerobic Sludge Blanket).
}




\section{LISTA DE SÍMBOLOS}

$\mathrm{AB} \quad$ Concentração de alcalinidade a bicarbonato, $\left(\mathrm{mgCaCO}_{3} / \mathrm{L}\right)$;

AI Concentração de alcalinidade intermediária, $\left(\mathrm{mgCaCO}_{3} / \mathrm{L}\right)$;

AP Concentração de alcalinidade parcial, $\left(\mathrm{mgCaCO}_{3} / \mathrm{L}\right)$;

AT Concentração de alcalinidade total, $\left(\mathrm{mgCaCO}_{3} / \mathrm{L}\right)$;

AVT Concentração de ácidos voláteis totais, $(\mathrm{mgHAc} / \mathrm{L})$;

$\mathrm{C}_{\mathrm{A}} \quad$ Concentração de matéria orgânica no afluente, (mgDQO/L);

COV Carga orgânica volumétrica, (mgDQO/L.dia);

$\mathrm{COV}_{\mathrm{IM}}$ Carga orgânica volumétrica para sistemas com biomassa imobilizada, (mgDQO/L.dia);

COE Carga orgânica volumétrica específica, (gDQO/gSVT.dia);

$\mathrm{C}_{\mathrm{E}} \quad$ Concentração de substrato, $(\mathrm{mgDQO} / \mathrm{L})$;

$\mathrm{C}_{\mathrm{EF}} \quad$ Concentração de substrato filtrado, $(\mathrm{mgDQO} / \mathrm{L}) ;$

$\mathrm{C}_{\mathrm{ET}} \quad$ Concentração de substrato total, (mgDQO/L);

$\mathrm{C}_{\mathrm{ET}}^{\mathrm{t}=0}$ Concentração de substrato filtrado no tempo zero de amostragem, $(\mathrm{mgDQO} / \mathrm{L})$

$\mathrm{C}_{\mathrm{ET}}^{\mathrm{t}=\mathrm{t}} \quad$ Concentração de substrato filtrada em tempo qualquer de amostragem, $(\mathrm{mgDQO} / \mathrm{L})$;

$\mathrm{C}_{\mathrm{S}} \quad$ Concentração de substrato no efluente para amostras filtradas (mgDQO/L);

$\mathrm{C}_{\mathrm{ST}} \quad$ Concentração de sólidos totais na espuma limpa, (mgST/g esp.limpa); 
C Concentração de sólidos voláteis totais na espuma limpa, (mgSVT/g esp.limpa);

F/M Relação substrato/microrganismo;

HAc. Ácido acético;

$k_{1} \quad$ Parâmetro cinético de primeira ordem aparente, $\left(\mathrm{h}^{-1}\right)$;

MLVSS "Mixed liquor volatile suspended solids", (g);

M $\quad$ Massa de espuma inoculada dentro do reator, $(\mathrm{g})$;

Q Vazão, $\left(\mathrm{m}^{3} / \mathrm{h}\right)$;

$\mathrm{r}_{\mathrm{S}} \quad$ velocidade de consumo de substrato (mgDQO/L.h);

SPE Substância polimérica extracelular;

SST Concentração de sólidos suspensos totais, $(\mathrm{mg} / \mathrm{L})$;

SSV Concentração de sólido suspensos voláteis, $(\mathrm{mg} / \mathrm{L})$;

ST Concentração de sólidos totais, $(\mathrm{mg} / \mathrm{L})$;

SVT Concentração de sólidos voláteis totais, $(\mathrm{mg} / \mathrm{L})$;

T Temperatura $\left({ }^{\circ} \mathrm{C}\right)$;

$\mathrm{t}_{\mathrm{c}} \quad$ Tempo de duração do ciclo, (h);

t $\quad$ Tempo de batelada $(\mathrm{h})$;

TRC Tempo de retenção celular, (d);

TDH Tempo de detenção hidráulico, (d);

$\mathrm{TDH}_{\mathrm{IM}}$ Tempo de detenção hidráulico para sistemas com biomassa imobilizada, (d);

V Volume (L);

$\mathrm{V}_{\mathrm{ALI}} \quad$ Volume de água residuária alimentado, (L); 
$\mathrm{V}_{\mathrm{t}} \quad$ Volume total do reator, (L);

X Quantidade de biomassa aderida em suporte inerte dentro do reator, (mgSVT);

$\varepsilon \quad$ Eficiência de remoção de matéria orgânica no sistema, (\%);

$\varepsilon_{\mathrm{ET}} \quad$ Eficiência de remoção total da matéria orgânica no sistema, (\%);

$\varepsilon_{\mathrm{EF}} \quad$ Eficiência de remoção de substrato filtrada no reator, (\%);

$\varepsilon_{\mathrm{P}} \quad$ Eficiência de remoção de substrato filtrada no reator para o perfil, (\%);

$\gamma \quad$ Relação entre a massa de espuma limpa e espuma inoculada no reator, (g espuma/g espuma inoculada). 
xxiv

\section{RESUMO}

SIMAN, R. R. Reator Anaeróbio em Batelada Seqüencial Contendo Biomassa Imobilizada Submetido a Aumento de Carga Orgânica Tratando Água Residuária Sintética. São Carlos, 2003. 170p. Dissertação (Mestrado) - Escola de Engenharia de São Carlos, Universidade de São Paulo.

Nesse estudo, procurou-se investigar a influência do aumento de carga orgânica em um ASBR operado a $30{ }^{\circ} \mathrm{C}$, agitado mecanicamente e contendo microrganismos imobilizados em suporte inerte. Para tal, foi aplicado um carregamento orgânico volumétrico variando de 1,5 a 6,0 gDQO/L.dia, alimentando-se um reator construído em acrílico $(5,4$ L) com 2 L de água residuária sintética com concentrações de 500 a 2000 $\mathrm{mgDQO} / \mathrm{L}$ com fontes de carboidrato/proteína/lipídio, em bateladas de 8 e $12 \mathrm{~h}$. O sistema apresentou eficiências de remoção de material orgânico entre $73 \%$ e $88 \%$ para as condições estudadas. Entretanto, quando o reator foi alimentado com uma concentração de 2000 $\mathrm{mgDQO} / \mathrm{L}$ em bateladas de $8 \mathrm{~h}$, verificou-se o acúmulo de ácidos voláteis totais, refletindo na redução da eficiência de remoção de material orgânico para 55\%, para amostras filtradas. Os perfis dinâmicos ao longo da batelada permitiram concluir que, para a condição com mesmo carregamento orgânico, porém com concentrações afluentes e tempos de ciclo diferentes, a produção inicial de ácidos voláteis totais foi mais acentuada para o caso de alimentação com maior concentração. Para condições com concentrações afluentes iguais, o tempo a mais para o ciclo foi fundamental para obtter-se efluente de melhor qualidade em termos de remoção de matéria orgânica.

Palavras-chave: reator anaeróbio operado em batelada seqüencial, biomassa imobilizada, espuma de poliuretano, sobrecarga orgânica, água residuária sintética. 


\section{ABSTRACT}

SIMAN, R. R. Effects of Increasing Organic Loading on the Performance of an Anaerobic Sequential Batch Reactor Containing Immobilized Biomass Treating Synthetic Wastewater. São Carlos, 2003. 170p. Dissertação (Mestrado) - Escola de Engenharia de São Carlos, Universidade de São Paulo.

The current study investigated the effect of increasing organic load in an ASBR operated at $30^{\circ} \mathrm{C}$ with mechanical stirring and containing immobilized on inert support. Accơrdingly, volumetric organic loading rates ranging from 1.5 to $6.0 \mathrm{gCOD} / \mathrm{L}$. day were used by feeding an acrylic reactor $(5.4 \mathrm{~L})$ with $2 \mathrm{~L}$ of influent at concentrations of 500 to $2000 \mathrm{mgCOD} / \mathrm{L}$ from wastewater containing carbohydrates, proteins and lipids in 8 and 12 h batches. Organic matter removal efficiencies between $73 \%$ and $88 \%$ were observed under the conditions investigated. However, when the reactor was fed at a concentration of $2000 \mathrm{mgCOD} / \mathrm{L}$ in $8 \mathrm{~h}$ batches, accumulation of total volatile acids was detected, leading to a reduction in organic matter removal efficiency as low as $55 \%$ for filtered samples. The dynamic batches profiles allowed to conclude that for the same organic loading rates and different concentration influent and cycle times, the initial production of total volatile acids showed to be more pronounced for better quality effluent in terms of organic matter removal.

Keywords: anaerobic sequential batch reactor, immobilized biomass, polyurethane foams, organic overloading, synthetic wastewater. 


\section{CAPÍTULO 1 INTRODUÇÃO}

Uma das características de importância fundamental, que habilita a utilização da biotecnologia do processo anaeróbio para o tratamento de águas residuárias, incide na manutenção de concentração elevada de biomassa ativa no interior do reator. Essa característica possibilita a aplicação de cargas orgânicas volumétricas elevadas, mantendo-se a estabilidade operacional. Com a viabilidade de se conseguir elevados tempos de retenção celular, trabalhando com baixos tempos de retenção hidráulica, as unidades de tratamento anaeróbio tornaram-se opção vantajosa para o tratamento de despejos líquidos, uma vez que o volume reacional projetado para sistemas com essas variáveis torna-se diminuído. Somado a isso, são reduzidas as dificuldades para o tratamento, transporte e disposição final dos lodos biológicos, haja vista que a síntese celular pelos microrganismos que proliferam em ambiente anaeróbio é muito menor do que os que utilizam o metabolismo aeróbio.

No Brasil, os reatores anaeróbios disponíveis tecnologicamente para aplicação, desde a pequenos aglomerados urbanos até a grandes cidades, são todos operados de 
modo contínuo, como por exemplo o decanto-digestor, o filtro anaeróbio, o reator de manta de lodo, o reator de leito expandido ou fluidificado e a lagoa anaeróbia.

Como alternativa aos sistemas anaeróbios contínuos de tratamento de águas residuárias, os processos intermitentes têm sido estudados, principalmente nos casos de indústrias com perfil sazonal de lançamento de seus efluentes ou que visam o reuso das águas residuárias ou de substâncias nelas dissolvidas. Dentre outras vantagens que apontam para a aplicação dos sistemas descontínuos de tratamento, pode-se citar o controle operacional mais eficiente, de grande importância nos casos de padrões de lançamento de efluentes muito restritivos e no caso da necessidade de se trabalhar com maiores tempos de retenção de líquido.

A utilização do reator anaeróbio operado em batelada seqüencial encontra grande aplicação para o tratamento de águas residuárias com elevadas concentrações de material orgânico, operando-se os reatores com cargas orgânicas volumétricas elevadas. Dentre estes resíduos destacam-se os efluentes da indústria de laticínios, os resíduos gerados na criação intensiva de gado suíno, bem como o chorume gerado em aterros sanitários. Para esses sistemas, o estudo da imobilização da biomassa em suporte inerte, permite ampliar o leque das opções disponíveis de sistemas anaeróbios de tratamento para efluentes municipais e industriais, pois elimina a incerteza a respeito do fenômeno de granulação do lodo, e dispensa o tempo que seria reservado para a sua decantação. Entretanto, a aplicação em escala plena deste reator ainda está distante. A elucidação de aspectos fundamentais e operacionais ainda se faz necessária para a utilização de um sistema eficiente e otimizado. 
Desta forma, o presente trabalho, em termos gerais, visa o estudo do comportamento do Reator Anaeróbio Operado em Batelada Seqüencial (Anaerobic Sequencing Batch Reactor -ASBR) com agitação mecânica e contendo biomassa imobilizada em cubos de espuma de poliuretano, submetida a diferentes cargas orgânicas volumétricas de um substrato sintético à base de sacarose/amido/celulose. 


\section{CAPÍTULO 2}

\section{OBJETIVOS}

O presente trabalho tem como objetivo avaliar desempenho de um ASBR provido de agitação mecânica, contendo biomassa imobilizada em cubos de espuma de poliuretano, submetido a diferentes taxas de carregamento orgânico volumétrico no tratamento de substrato sintético contendo carboidratos, proteína e lipídeo. Foram estabelecidos, ainda, os seguintes objetivos específicos:

- Concepção, projeto, construção e operação de um reator anaeróbio em escala de bancada, com agitação mecânica do meio reacional, operado em batelada seqüencial e contendo biomassa imobilizada em cubos de espuma de poliuretano;

- Avaliação da estabilidade operacional e da eficiência de remoção de material orgânico quando o sistema é submetido a diferentes concentrações afluentes, operando o reator com bateladas de 8 e 12 horas de duração. 


\section{CAPÍTULO 3}

\section{REVISÃO BIBLIOGRÁFICA}

\subsection{Generalidades}

Segundo TUNDISI \& BARBOSA (1995), o Brasil possui uma ampla rede hidrográfica em relação ao mundo. Do total de água captada para uso doméstico, $51 \%$ dos sistemas existentes estão localizados em rios, nos quais são lançados in natura $92 \%$ dos esgotos gerados nas regiões. A pequena parcela de esgoto tratado passa por unidades de grande porte que centralizam os dejetos em grandes volumes e em estações tecnologicamente sofisticadas.

O processo biológico anaeróbio ocorre na ausência de oxigênio molecular através da interação de microrganismos, transformando compostos orgânicos complexos em produtos mais simples como metano, gás carbônico e outros subprodutos de degradação parcial. A remoção da matéria orgânica (geralmente expressa em Demanda Química de Oxigênio - DQO) é efetiva, pois os produtos gasosos desta degradação apresentam baixa solubilidade em água, sendo facilmente removidos. 
Segundo LETTINGA (1995) e HARPER \& POHLAND (1986), os inconvenientes antigamente atribuídos ao tratamento anaeróbio de resíduos, como alta susceptibilidade das arqueas metanogênicas e bactérias acetogênicas à compostos tóxicos, baixa estabilidade do tratamento e mal odor do efluente, foram superados e constatou-se que o que realmente acontecia era a falta de conhecimentos específicos quanto a digestão anaeróbia, tratando o processo sem o controle que a operação necessita.

Para se disponibilizar um sistema de reatores anaeróbios ao tratamento de altas taxas de carregamento volumétrico de águas residuárias, LETTINGA (1994) aponta cinco condições básicas que devem ser alcançadas: operar o reator com longo tempo de retenção de lodo ativo, promover o suficiente contato entre a biomassa bacteriana e a água residuária, evitando-se regiões mortas sem valor para o tratamento, manter altas velocidades de reação e ausência de grandes limitações com fenômenos de transferência de massa, promover a adaptação da biomassa à água residuária sujeita ao tratamento e por último, mas não menos importante, propiciar condições ambientais favoráveis, no interior do reator, para todos os organismos requeridos na digestão anaeróbia.

FORESTI (1994), LETTINGA (1995) e VAN HAANDEL \& LETTINGA (1994) citam as principais vantagens do processo anaeróbio comparados com processos aeróbios convencionais, à luz do desenvolvimento de métodos e tecnologias sustentáveis: baixo consumo de energia e baixo custo com construção devido à redução do número de unidades operacionais; baixa produção de lodo, estimada como inferior a $20 \%$ do lodo gerado em processos aeróbios convencionais, sendo que o lodo anaeróbio se encontra quase sempre estabilizado, os microrganismos anaeróbios podem ser 
preservados por longos períodos na falta de alimento sem grandes alterações na atividade biológica devido à velocidade de decaimento do lodo ser muito baixa e possibilidade de utilização do gás metano como combustível.

As principais desvantagens estão na possibilidade de geração de odores (porém controlável), longos períodos de partida e sensibilidade do processo a mudanças ambientais, devido à digestão anaeróbia depender muito mais de mecanismos reguladores intrínsecos que de controles externos. O processo depende essencialmente das interações de diversos grupos de microrganismos capazes de manter o $\mathrm{pH}$ e o potencial redox do sistema para otimizar a metanogênese.

\subsection{Retenção Microbiana em Reatores Anaeróbios}

A biotecnologia de processos anaeróbios para tratamento de águas residuárias tem se desenvolvido de forma extraordinária com a introdução de reatores contendo biomassa imobilizada, uma vez que esses reatores permitem o aumento da concentração de biomassa ativa em seu interior. Desta forma, os reatores estariam aptos ao tratamento de águas residuárias com taxas de carregamento orgânico volumétrico elevadas objetivando a máxima utilização de substrato mantendo a estabilidade operacional (HENZE \& HARREMOËS, 1983; HUYSMAN et al., 1983; FYNN \& WHITMORE, 1984; CONSTERTON et al., 1995; LETTINGA, 1995). Os autores citam que uma das formas de retenção das bactérias seria alcançado pela sua imobilização na forma de 
agregados (grânulos ou flocos) com boa característica de sedimentação ou na forma agregada em suporte inerte formando os biofilmes.

A principal diferença destes reatores, em relação aos convencionais, é que eles propiciam a operação com tempos de residência celular elevados, mesmo quando operados com baixos tempos de residência hidráulico, resultando em diminuição do volume reacional, tornando-os economicamente viáveis.

Fica evidente que a agregação de microrganismos anaeróbios, seja em grânulos ou outra forma de imobilização, otimiza a cooperação entre os organismos associados, principalmente pela redução da distância de difusão para transferência de produtos metabólicos, atuando como forma de proteção extra contra fatores ambientais adversos e a presença de compostos inibidores/tóxicos (VAZOLLER et al., 1999; GUIOT et al. 1992). CONSTERTON et al. (1995) notaram que células agregadas em biofilme poderiam resistir até 500 vezes mais a agentes bactericidas.

Segundo CONSTERTON et al. (1995), biofilme é definido como uma população de microrganismos confinados, aderida umas as outras e/ou a uma superfície ou interface. Esta definição inclui agregado microbiano ou flocos e também populações dentro de poros ou no meio poroso.

Uma importante colocação a respeito de biofilmes foi feita por CAMPOS (1994) que exclui os agregados microbianos na forma de biofilme da comparação com simples “invólucros" contendo enzimas, como fazem a maior parte dos estudos, pois eles geralmente formam um consorcio bacteriano heterogêneo e complexo em que pode haver ativa simbiose ou até mesmo competição de microrganismos por um substrato comum. A micro colônia é a base única do biofilme adulto. 
Uma ampla variedade de materiais porosos pode ser usado como superfície para imobilização da biomassa, destacando-se areia ou rochas vulcânicas, pedaços de madeira, escória siderúrgica, óxido da alumínio, vidro, grãos de material sintético, espumas naturais ou artificiais, carvão ativado, pedras, material cerâmico, bambu e módulos ou peças de material sintético (HUYSMAN et al, 1983; FYNN \& WHITMORE, 1984; CAMPOS, 1994).

A adesão do microrganismo, e subseqüente formação do biofilme é rápida e resistente, dependendo, em uma primeira fase, da natureza física e química das superfícies da bactéria e do meio suporte (VERRIER, 1987; CONSTERTON et al., 1995) e do regime de fluxo imposto ao seio do fluido.Após a adesão inicial, a natureza da superfície influencia muito pouco na velocidade de formação do biofilme (HUYSMAN et al., 1983; HAMILTON, 1987). Neste momento da adesão, o que realmente importa é a disponibilidade de nutrientes no meio aquático que, por sua vez, proporcionará a replicação celular em diferentes padrões de colonização e a produção de uma matriz polimérica extracelular composta por uma grande variedade de material orgânico incluindo-se: polissacarídeos, proteínas, ácidos nucléicos, (fosfo)lipídios, ácidos úricos e substancias úmicas. Essas substâncias poliméricas extracelulares (SPE), que em um biofilme maduro podem chegar a compor $89 \%$ do seu volume total (ZANG \& FANG, 2001), tem um importante papel na comunidade microbiana além da função estrutural, dentre as quais as mais importantes são: adesão e agregação celular, granulação, biocolmatação, comunicação entre as células e proteção contra a ação tóxica como a de metais pesados (RIBEIRO, 2001; ZANG \& FANG, 2001). 
Após as primeiras fases da formação do biofilme, as células subseqüentes já podem começar a aderir às superfícies, agora de forma irreversível. Esta justaposição e a grande produção de uma matriz de exopolímeros são as condições micro-ambientais necessárias para o desenvolvimento de cada biofilme bacteriano.

Estudos usando microscopia ótica, eletrônica de varredura e varredura a laser confocal revelam biofilmes microbianos com estrutura bem heterogênea (CONSTERTON et al., 1995; ZANG \& FANG, 2001; RIBEIRO, 2001). Esta característica de heterogêneidade é a chave da estabilidade dessa justaposição eventual de microrganismos, onde a cooperação funcional torna-se bem mais ativa (FLETCHER ${ }^{1}$ apud CONSTERTON, 1995; VAZOLLER et al., 1999).

\subsection{Fatores Ambientais na Digestão Anaeróbia}

Vários são os fatores que influenciam o desempenho da digestão anaeróbia de águas residuárias. Dentre os fatores ambientais se destacam a temperatura, o $\mathrm{pH}$ e alcalinidade, a presença de nutrientes e de cargas tóxicas.

\section{Temperatura}

A temperatura é um dos fatores ambientais mais importantes na digestão anaeróbia uma vez que afeta os processos biológicos de diferentes maneiras. Dentre os 136.

${ }^{1}$ FLETCHER, M. (1987) How do bacteria attach to solid surfaces? Microbiology Society 4:133- 
principais efeitos da temperatura incluem-se as alterações na velocidade do metabolismo das bactérias, o equilíbrio iônico e na solubilidade dos substratos, principalmente de lipídios, e a biodisponibilidade do ferro (SPEECE, 1996; VAN HAANDELL \& LETTINGA, 1994; BENEFIELDS \& HANDAL, 1980). ZENDER et al. (1982), estudando culturas mistas e puras, observaram que a formação de uma microbiologia metanogênica ocorre sob uma ampla faixa de temperatura relatada entre $0^{\circ} \mathrm{C}$ e $97^{\circ} \mathrm{C}$, dentro da qual ocorre crescimento bacteriano. Nesse intervalo, FORESTI (1994) apresenta duas faixas de temperaturas para o lodo nos quais os tempos de digestão são menores que aqueles observados a temperaturas superiores às das faixas ótimas. Estas faixas de temperatura, denominadas mesofílicas e termofílicas, situam-se em torno de 30 e $50^{\circ} \mathrm{C}$, respectivamente. Geralmente os reatores operam a temperaturas mesofílicas (30 a $\left.37^{\circ} \mathrm{C}\right)$.

Para locais muito frios ou para casos em que não se torne economicamente viável aquecer o reator, pode-se trabalhar com reatores psicrofílicos com elevados tempos de retenção celular. No trabalho desenvolvido por MASSÉ et al. (1997), demonstrou-se a aplicabilidade de reatores anaeróbios operados em bateladas seqüenciais trabalhando em faixa psicrofílica de temperatura, no qual se contatou alta eficiência na remoção de matéria orgânica solúvel e redução de odor, quando empregados para o tratamento de resíduo de pocilgas. 


\section{pH e Alcalinidade}

Para que a produção de metano não seja afetada, SPEECE (1996) preconiza que, para o sucesso de um processo anaeróbio, o $\mathrm{pH}$ do meio deve ser mantido entre 6,5 a 8,2, embora sob algumas condições seja possível operar satisfatoriamente a $\mathrm{pH}$ de 6,0. O autor enfatiza que o tratamento de esgotos sanitários em reatores anaeróbios de elevado carregamento orgânico dificilmente exigirá cuidados com relação à manutenção do pH na faixa adequada, pois um valor adequado é obtido naturalmente devido, ao sistema carbônico $\left(\mathrm{H}_{2} \mathrm{CO}_{3} ; \mathrm{HCO}_{3}{ }^{-} ; \mathrm{CO}_{3}{ }^{2-}\right)$ ser gerado no metabolismo anaeróbio e poder estar contido no esgoto afluente. Atenção especial deve ser dada ao tratamento de águas residuárias de mais fácil degradação (ricas em açúcar e amido) que estariam susceptíveis ao desbalanceamento (FORESTI, 1999; BAGLEY \& BRODKORB, 1999).

\section{Nutrientes}

Nitrogênio $(\mathrm{N})$ e fósforo $(\mathrm{P})$ e geralmente o enxofre (S) são os nutrientes essenciais para todos os processos biológicos, sejam eles aeróbios ou anaeróbios. Uma estimativa grosseira da quantidade destes macronutrientes $(\mathrm{P}, \mathrm{N}, \mathrm{S})$ requerida pode ser obtida, segundo LETTINGA (1995), a partir da composição da bactéria e crescimento bacteriano do lodo em questão. ALPHENAAR ${ }^{2}$ apud LETTINGA (1995) verificou a

\footnotetext{
${ }^{2}$ ALPHENAAR, P.A. (1994) Anaerobic granular sludge: Characterization and factors affeting its performance. PhD Thesis, Wageningen Agricultural University, The Nethelands.
} 
variação na quantidade de fósforo de 6,5 para $37 \mathrm{mg} \mathrm{P} / \mathrm{mg}$ SSV no lodo granular de um reator em escala real. Dessa forma, deve-se tomar o devido cuidado com relação à presença de fosfatos precipitados, que podem dar uma interpretação dúbia quanto à composição de macronutrientes.

Em geral, admite-se que a relação de DQO:N:P de 500:5:1 seja suficiente para atender às necessidades de macronutrientes dos microrganismos anaeróbios (SPEECE, 1996).

Dentre os micronutrientes considerados essenciais, sem a qual a metanogênese é sensivelmente afetada, destacam-se principalmente os metais traços: $\mathrm{Fe}$, Ni e Co. LETTINGA (1995) ampliou esta lista incluindo nutrientes como Ca, Mo, Ni, Na, Se e V sem os quais o crescimento das arqueas metanogênicas em sistema alimentado com metanol foi bastante prejudicado. Um exemplo disso foi verificado em uma planta piloto de pequeno porte, projetada para o tratamento de água residuária da indústria de farinha de batata, que só veio a apresentar bom desempenho quando uma solução de elementos traços foi adicionada ao reator (LETTINGA, 1995).

É pouco provável que os esgotos sanitários típicos apresentem deficiência nutricional, pois tanto os macros quanto os micronutrientes estão presentes de forma abundante no esgoto sanitário, ao contrário de algumas águas residuárias industriais. $\mathrm{Na}$ verdade, em muitos casos será necessária a aplicação de pós - tratamento para reduzir a concentração dos macronutrientes.

\section{Toxidade}


Uma característica importante que influi na escolha do processo utilizado no tratamento biológico de resíduos industriais é a capacidade de resistir a um composto presente no meio, que pode ter uma ação tóxica aos microrganismos. Este é um dos pontos importantes que levaram ao aumento do número e do tipo de indústrias que optaram pelo processo anaeróbio de tratamento, ao invés de sistemas aeróbios, para o caso de resíduos industriais: a capacidade de acomodar um composto tóxico e até mesmo biodegradá-lo. Muitos compostos tóxicos são biodegradados apenas sob condições anaeróbias como, por exemplo, tetracloreto de carbono e tetracloroetileno e outros perderão sua toxidade após sofrerem tratamento anaeróbio como formaldeído, acrilato, clorofórmio, tricloroetileno e cianetos (SPEECE, 1996).

A palavra chave para esta característica é adaptação. Uma vez adaptada com concentrações pequenas do compostos tóxicos, trabalhando com altos tempos de retenção celular para o desenvolvimento de biota de microrganismos apta ao tratamento, a biomassa estará pronta para degradar o composto em condições normais. Para reatores anaeróbios operados à temperatura ambiente na faixa de $20^{\circ} \mathrm{C}$ a $30^{\circ} \mathrm{C}$, é aconselhável que o tempo de retenção celular seja da ordem de 50 dias ou mais e que reatores de filme fixo, como filtros anaeróbios, por exemplo, têm demonstrado ser mais resistente à toxicidade que reatores de crescimento em suspensão (FORESTI et al., 1999).

Quanto à tolerância ao oxigênio em sistemas anaeróbios, KATO et al. (1997) esclarece que a biota proveniente de estações de tratamento de água residuária é tolerante ao oxigênio dissolvido no meio reacional, particularmente as metanogênicas. Isso se deve a coexistência de microrganismos aeróbios e aeróbios facultativos nos 
biorreatores anaeróbios. A possibilidade da presença de coculturas aeróbias/anaeróbias amplia ainda mais o leque de aplicação dos sistemas anaeróbios.

\subsection{Reatores Anaeróbios Operados em Batelada Seqüencial (ASBR)}

\subsubsection{Histórico}

Observações experimentais de Mckinney e Pteffer no final dos anos 60 e trabalhos de Fuller, Schroepfer, Steffen e outros co-autores, ainda por volta dos anos 50, mostraram o nascimento dos processos anaeróbios de altas cargas orgânicas chamado de "processo de contato anaeróbio", nos quais foi verificado que a floculação da biomassa se dava de maneira análoga à que ocorre nos processos de lodos ativados (floculação eficiente e rápida sedimentação), quando sob baixas relações alimento/biomassa.

Atentado para esta observação, Dague, em meados dos anos 60, estudou uma maneira de aumentar a população microbiana dentro do reator. Estes estudos envolviam alimentação intermitente a separação dos sólidos e resíduos sobrenadantes em único reator. A este processo deu-se o nome de "lodo anaeróbio ativado", que alcançava altos tempos de retenção celular (TRC) com curtos tempos detenção hidráulico (TDH) e separação satisfatória de sólidos, resultando em efluente de boa qualidade. Dague e seus

colaboradores desenvolveram o processo chamado de "anaerobic sequencing batch reactor --ASBR" na Universidade do Estado de Iowa (U.S. Patente $\mathrm{N}^{\mathrm{o}}$ 5.185.070). 


\subsubsection{Princípios Fundamentais}

O princípio de operação para o sistema ASBR é bastante simples, podendo-se enumerar em quatro as principais fases de operação como mostra a FIGURA 3.2: alimentação intermitente com água residuária, reação pelos microorganismos, sedimentação final do lodo biológico e decantação do liquido tratado e clarificado.

A freqüência de ciclos e o volume de substrato processado em cada batelada determinam a carga hidráulica, enquanto que a quantidade de resíduo alimentado estabelece a carga orgânica aplicada (DAGUE et al., 1992). A característica que permite, ao ASBR, alcançar velocidades de conversão significativas é a alta concentração de matéria orgânica logo após a etapa de alimentação, resultando em grande atividade metabólica, e baixa concentração de substrato próximo ao final da etapa de reação, resultando em baixa produção de gás e condições ideais para a floculação e sedimentação mais acelerada (DAGUE et al., 1992; SUNG \& DAGUE, 1995; ANGENENT \& DAGUE, 1995). Dessa forma, em reatores operados em batelada, a formação de grânulos, a biodegradação e a capacidade de sedimentação podem ser mais eficientes que nos sistemas contínuos. 

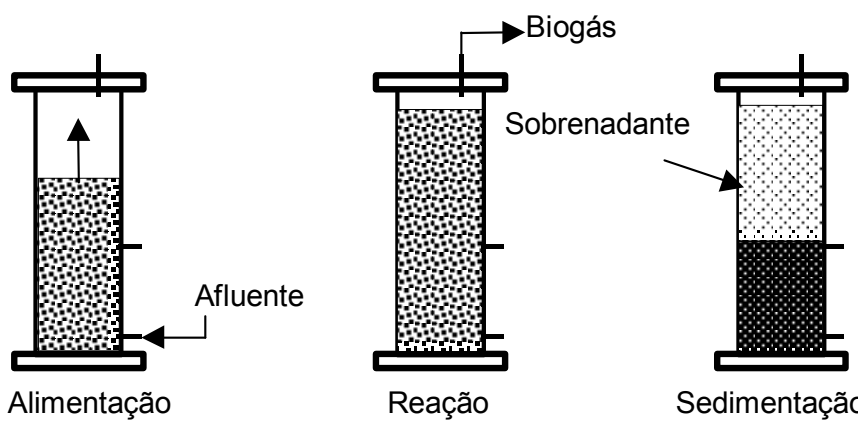

Reação

Sedimentação

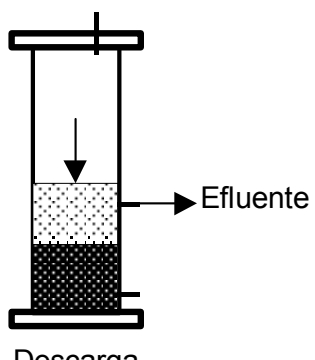

FIGURA 3.2 - Representação das quatro fases de operação de um ASBR.

Adaptado de DAGUE et al. (1992).

\subsubsection{Fatores que Afetam o Desempenho}

Analisando os fatores que mais afetam o desempenho dos reatores ASBR, ZAIAT et al. (2001) mencionam que a homogeneização do sistema, seja através de agitação mecânica, seja pela recirculação de gás ou líquido, promove o maior contato de sólido/líquido, auxiliando no processo de transferência de massa. Entretanto, a agitação excessiva pode causar a ruptura dos grânulos (ANGENENT \& DAGUE, 1995). Em trabalho mais recente, ANGENENT et al. (2001) complementam que, embora se acredite que a agitação contínua seja necessária para a digestão de resíduo animal em reator seqüencial em batelada, como o proveniente de pocilgas, a agitação suave e intermitente torna-se mais vantajoso para o desempenho do reator.

Outro aspecto importante referente à agitação foi investigado por RATUSZNEI et al. (2001), no tratamento de água residuária sintética com carga orgânica volumétrica de aproximadamente $750 \mathrm{mgDQO} / \mathrm{L}$ dia. Os autores verificaram que a intensidade de 
agitação afeta sensivelmente o tempo necessário para se atingir a eficiência máxima de remoção de matéria orgânica, diminuindo o tempo global da batelada.

Outra característica que afeta o desempenho do reator intermitente é a sua característica geométrica, uma vez que o tipo de biomassa (floculenta ou granular) é afetado diretamente por este parâmetro. SUNG \& DAGUE (1995), ANGENENT \& DAGUE (1995); DUGBA et al. (1999) e ZAIAT et al. (2001) citam que a eficácia na retenção de biomassa, dentro do reator, possui relação com a maior eficiência do sistema ASBR.

A estratégia de alimentação, a qual está diretamente relacionada com a relação F/M (substrato e biomassa), também é uma variável importante, pois afeta o fenômeno de granulação da biomassa. REYES III \& DAGUE (1995), trabalhando com relação F/M variando de 0,09 a 1,00 (mgDQO/mg SSV), observaram que a melhor remoção foi alcançada utilizando uma relação F/M de 0,5.

SUNG \& DAGUE (1995) indicam o problema relativo à carga orgânica para a formação de grânulos com melhores características de sedimentação, de acordo com os resultados obtidos quando utilizado uma relação média de F/M de 227 gDQO/g MLVSS ("mixed liquor volatile suspended solids") e carga orgânica volumétrica de $15 \mathrm{gDQO} / \mathrm{L}$ d de água residuária sintética, com remoção acima de 90\%, em contraste com outros trabalhos que apresentam quedas de eficiência de remoção com cargas orgânicas acima de 4 gDQO/L.dia, indicando o problema de se trabalhar com grandes relações F/M e conseguir boa retenção de biomassa na forma auto-imobilizada.

Ainda com relação à estratégia de alimentação, a influência do tipo de água residuária é outro fator importante, pois alguns despejos podem, potencialmente, causar 
problemas operacionais devido às altas velocidades de acidificação em função de suas características de biodegradação (lenta ou rápida). De acordo com BAGLEY \& BRODKORB (1999), sistemas anaeróbios em batelada estariam susceptíveis ao desbalanceamento no tratamento de águas residuárias de mais fácil degradação.

O problema da incerteza da granulação levou WIRTZ \& DAGUE (1997) a pesquisar o efeito da adição de polímeros catiônicos para reduzir o tempo necessário para a formação do grânulo (tempo de partida), reduzindo-o em $75 \%$ para estudos com águas residuárias sintética à base de sacarose em reatores de bancada de 12 litros. No entanto, a introdução de polímeros poderia encarecer o processo de digestão anaeróbia devido à necessidade de se introduzir de novos equipamentos mistura e adição de novos compostos químicos.

\subsubsection{Aplicações do Sistema ASBR}

Devido a um controle operacional mais eficiente, os sistemas anaeróbios intermitentes têm sido extensivamente estudados como alternativa aos contínuos, principalmente nos casos em que os padrões de lançamento de efluentes são muito restritivos, resultando na necessidade de se trabalhar com maiores tempos de retenção de líquido. Indústrias com perfil sazonal de lançamento de seus efluentes ou que visam o reuso das águas residuárias ou de substâncias nelas dissolvidas também apontam para a aplicação dos sistemas intermitentes de tratamento.

Comparado com um sistema semelhante de alimentação contínua tipo UASB, ANGENENT \& DAGUE (1995) mostraram que ambos tiveram eficiências de remoção 
de matéria orgânica, na forma de DQO, acima de $90 \%$ em três meses de operação. Os grânulos do ASBR se mostraram menores e mais densos, portanto, de sedimentação mais rápida e, conseqüentemente, o ASBR seria menos sujeito à perda de sólidos.

SPEECE (1996) e KATO et al. (1999) também relatam outro aspecto muito importante do sistema em batelada. Apesar de necessitar de volume reacional maior para uma mesma eficiência de remoção de matéria orgânica, comparado com um sistema semelhante de alimentação contínua, o sistema em batelada apresenta a vantagem de tornar desnecessária a construção de um sedimentador em separado, bem como a recirculação externa de lodo biológico, o que torna o custo de implementação da unidade de tratamento menor e facilita sua operação.

Atualmente, o reator anaeróbio operado em bateladas seqüenciais tem sido estudado para o tratamento de águas residuárias com elevadas concentrações de materia orgânica. Dentre estes resíduos, destacam-se os efluentes da indústria de laticínios, os resíduos gerados na criação intensiva de gado suíno e o chorume gerado em aterros sanitários, nos quais as concentrações de material orgânico variam de 60 a 80 gDQO/L (YAN et al., 1988, PODLECH et al., 1991), 210 a 340 gDQO/L (SCHMIT \& DAGUE, 1993) e 31 a $90 \mathrm{gDQO} / \mathrm{L}$ (HOLLOPETER \& DAGUE, 1996), respectivamente.

Em 1989, foi publicado um trabalho em que se aplicava um reator anaeróbio operado em bateladas seqüenciais para o tratamento de água residuária proveniente de pocilga (NG, 1989). Naquela época já se vislumbrava a aplicação do reator operado em batelada para grandes taxas de carregamento orgânico. Para o tratamento de cargas orgânicas de 0,40 a 6,45 gDQO/L.dia e 0,20 a 2,45 gDBO/L.dia, para amostras não 
filtradas, o autor encontrou eficiências de remoção entre 53 a $85 \%$ e 68 a $89 \%$ respectivamente, usando TDH de 15, 10, 5, 3 e 1 dia.

DAGUE et al. (1992) estudaram a tratabilidade de resíduo a base de leite em pó desnatado e resíduo diluído de suinocultura (1:4) em ASBR de 13 L e 12 L de volume útil respectivamente, operado com quatro ciclos diários. Com o leite desnatado, os autores trabalharam a $35^{\circ} \mathrm{C}$, com três faixas de concentrações afluentes distintas ( 1 a 10 ; 0,6 a 6 e 0,3 a 3 gDQO/L) e $\mathrm{TDH}(0,54 ; 1,08$ e 2,17 dias $)$ varrendo desta forma, uma faixa de COV de 0,5 a 5 gDQO/L.dia. Nestes casos, a remoção de matéria orgânica se manteve acima de $80 \%$ para os TDH de 2,17 e 1,08 dia para os valores de COV até 4 gDQO/L.dia e até 2 gDQO/L.dia com TDH de 0,54 dia. No caso do estudo com resíduo de pocilga, trabalhando com um TDH fixo em 6 dias e duas faixas de concentração $(6,3$ a $40 \mathrm{gDQO} / \mathrm{L}$ com reator mantido a $35^{\circ} \mathrm{C}$ e 6,5 a $32 \mathrm{gDQO} / \mathrm{L}$ a $25^{\circ} \mathrm{C}$ ) varrendo uma faixa de COV de 1,09 a 5,38 gSV/L.dia e 1,04 a 6,82 gSV/L.dia, respectivamente. Neste estudo, as eficiências de remoção de sólidos voláteis estiveram acima de $74 \%$ para toda a faixa de COV estudados.

SCHMIT \& DAGUE (1993), tratando resíduo de pocilga, propuseram o estudo para a temperatura de $20^{\circ} \mathrm{C}$ sob três faixas de concentrações distintas $(8,4$ a $32 \mathrm{gSV} / \mathrm{L}$, 8,4 a $35 \mathrm{gSV} / \mathrm{L}$ e 11 a $35 \mathrm{gSV} / \mathrm{L}$ ) em reator de $12 \mathrm{~L}$ e um ciclo por dia, sob três condições de alimentação (TDH de 6, 9 e 12 dias) varrendo, desta forma, uma ampla faixa de $\operatorname{COV}(0,93$ a 5,37 g SV/L.dia). Como resultado, para um TDH de 6 dias a percentagem de destruição de sólidos voláteis cresceu de 41 para $48 \%$, caindo para $43 \%$ na concentração de $32 \mathrm{gSV} / \mathrm{L}$ (COV de 5,37 gSV/L.dia). Na segunda e terceira 
condições (TDH 9 e 12 dias), obteve-se porcentagens de destruição máximas de sólidos voláteis de 55,0 e $67,2 \%$ respectivamente.

CHANG et al. (1994) avaliaram o desempenho do sistema anaeróbio operado em bateladas seqüenciais para a digestão de lodo concentrado de estação de tratamento de esgoto com a concentração variando de 11,11 a 21,62 gDQO/L. Operando um reator de 4 litros de volume útil, os pesquisadores utilizaram tempos de ciclo de 3 e 4 dias, alimentando 30 e $40 \%$ do volume líquido do reator, respectivamente. Desta forma, com taxas de carregamento orgânico volumétricos variando entre 1,11 a 2,20 gDQO/L.dia e TDH de 10 dias, eficiência de DQO acima de 90\% foram verificadas para ambas as condições.

SUNG \& DAGUE (1995), com objetivo de avaliar o efeito da configuração do reator e agitação (intermitente e contínua) no desempenho de um reator ASBR de 12 L, aplicaram taxas de carregamento orgânico volumétricas de 2, 4, 6 e 8 gDQO/L.dia para reatores operados com tempos de detenção hidráulicos de 1 e 2 dias e de 2, 4, 6, 8, 10 e 12 gDQO/L.dia com tempo de detenção hidráulico de 0,5 dia, através da alimentação de solução a base de leite em pó desnatado, com concentração variando de 4,0 a 24 gDQO/L. Operando os reatores com quatro ciclos diários, os autores verificaram remoção de matéria orgânica acima de $90 \%$ para todos os casos.

REYES III \& DAGUE (1995) utilizaram reatores de $10 \mathrm{~L}$ a $35^{\circ} \mathrm{C}$ e TDH de 1 dia para o tratamento de leite em pó desnatado com o objetivo determinar a concentração de biomassa granular ótima para a taxa de carregamento orgânico aplicada, o que levaria a uma partida rápida e estável. As concentrações utilizadas para que se alcançasse um carregamento orgânico de 1,5 a 10 gDQO/L.dia foram de 1,5 a 10 gDQO/L. É 
importante lembrar que, com esta manipulação experimental, foi possível observar partidas com relação substrato/microrganismos (F/M) variando de 0,09 a 1,33 mgDQO/mg SSV.dia. De acordo com os autores, uma relação F/M de 0,5 leva a uma partida rápida e estável.

ANGENENT \& DAGUE (1995) fizeram uma comparação entre os reatores de manta de lodo (UASB) e o de batelada seqüencial (ASBR), tratando água residuária sintética à base de sacarose em reatores de 12 e $13 \mathrm{~L}$ respectivamente a $35^{\circ} \mathrm{C}$. $\mathrm{O}$ reator anaeróbio em batelada seqüencial foi operado com ciclo diários de 6 horas, e concentração de substrato afluente que variava de 3 a 9,5 gDQO/L contra as 3 a 11,5 gDQO/L aplicadas no reator contínuo UASB. Estas concentrações imprimiam a taxa de carregamento orgânico que máximo de 19 gDQO/L.dia para o ASBR e 23 gDQO/L.dia para o UASB, sendo ambos os reatores operados com TDH 0,5 dia. Como resultado, ambos os reatores apresentaram remoção de material orgânico na forma de DQO solúvel superior a 90\%, em menos de três meses de operação.

A característica principal que apontou para a superioridade do sistema em batelada sobre o contínuo, tratando água residuária à base de sacarose, foi a retenção de sólidos suspensos voláteis. No final da operação, o ASBR apresentou concentração de $\mathrm{SSV}$ de $30 \mathrm{~g} / \mathrm{L}$ contra as $12 \mathrm{~g} / \mathrm{L}$ mostradas pelo UASB, devido ao granulo encontrado no ASBR se apresentar mais denso e com boa sedimentabilidade.

HIRL \& IRVINE (1996) mostraram a versatilidade da aplicação do sistema anaeróbio operado em bateladas seqüenciais para o tratamento de resíduos perigosos. Em seus trabalhos foi verificada a descloração redutiva de percloroetileno para etileno 
ZHANG et al. (1996) utilizaram o reator anaeróbio operado em batelada seqüencial para o tratamento de resíduo de pocilga, utilizando tempos de retenção hidráulicos de 2 a 6 dias e carregamentos de sólidos voláteis variando de 0,9 a 5,5 gSV/L.dia. Em seus trabalhos, a remoção de sólidos voláteis esteve sempre entre 40 a 60\%. Para a aplicação do ASBR para o tratamento de dejetos animais em unidades agrícolas, o sistema em batelada encontra boa aplicação, uma vez que a limpeza das cocheiras dos animais é feita de forma intermitente.

Para o tratamento de percolado de aterro sanitário (chorume), HOLLOPETER \& DAGUE (1996), testaram um sistema ASBR de $12 \mathrm{~L}$ a $35^{\circ} \mathrm{C}$ com 4 ciclos diários. Uma ampla faixa de concentração foi aplicada, utilizando-se 4 estratégias de alimentação (TDH de 2,0;1,5;1,0;0,75 e 0,5 dia). Desta forma, foi avaliado o desempenho para valores de $\mathrm{COV}$ variando de 1,6 a 3,5 gDQO/L.dia. Para alcançar os padrões de lançamento requeridos na região, uma unidade aeróbia de lodos ativados foi instalada para polimento do efluente da etapa anaeróbia. Nos estudos em questão, a unidade anaeróbia (ASBR) removeu 85 a 90\% da DQO solúvel afluente em todos as estratégias de alimentação, e juntos (sistemas anaeróbio e aeróbio) foram capazes de atingir índices de remoção de DQO solúvel de 94 a 99\%.

MASSÉ et al. (1997) avaliaram a aplicabilidade do sistema ASBR para o tratamento de dejetos de pocilga na faixa psicrofílica de temperatura. Atentando para a ausência de uma definição para o termo carga orgânica volumétrica para o sistema ASBR, os autores descrevem neste trabalho várias formas de representá-la. Baseado no volume líquido alimentado, a faixa de carga orgânica volumétrica estudada foi de 0,58 a 1,36 gDQO/L.dia com concentrações afluentes variando de 14 a 86 gDQO/L, 
aproximadamente. Nestes estudos, as eficiências de remoção de DQO solúveis ficaram entre 50 a $83 \%$.

WIRTZ \& DAGUE (1997) estudaram o fenômeno de granulação no reator anaeróbio, tratando água residuária sintética à base de sacarose, com o objetivo de estudar métodos de redução do tempo de partida de reatores anaeróbios operados em bateladas seqüenciais. Para tal, os autores utilizaram reatores de $12 \mathrm{~L}$ de volume útil e aumnetaram de 3 gDQO/L.dia para 12 gDQO/L.dia utilizando quatro ciclos diários e mesmo tempo de detenção hidráulico (1 dia). As concentrações afluentes variaram de 3 para $12 \mathrm{gDQO} / \mathrm{L}$. Talvez o mais significante benefício que a melhoria na imobilização do lodo na forma de grânulos, seja o aumento na capacidade de remoção de matéria orgânica e a redução do tempo de partida dos reatores. Para todos os valores de COV aplicados, a remoção de DQO solúvel foi superior a $80 \%$ e o tempo requerido para alcançar tratamento estável para a COV de 4 gDQO/L.dia foi reduzido em 60\%, quando comparado a um reator de controle.

NDON \& DAGUE (1997) utilizaram reator de 6 L para tratar água residuária sintética, a base de leite em pó desnatado, com concentrações de 1000, 800, 600 e 400 mgDQO/L, sob TDH de 48, 24, 16 e 12 horas. Este estudo mostrou remoção de DQO entre 88 a 90\%, exceto para alimentação de 800 e 1000 mgDQO/L com TDH de 12 horas, e alimentação de $1000 \mathrm{mgDQO} / \mathrm{L}$ com TDH de 16 horas nos quais se observou queda de eficiência e perdas de sólidos.

BRITO et al. (1997), inovando o sistema ASBR pela introdução de sistema para promover a agitação da etapa de reação através de bomba tipo diafragma, tratou efluente com concentrações próximas a $1000 \mathrm{mgDQO} / \mathrm{L}$ com eficiências de 60 a $70 \%$. 
TIMUR \& OZTURK (1999) verificaram que a eficiência na remoção de carga orgânica, como DQO, depende das taxas de carregamento orgânico volumétrica e especifica aplicados, tratando percolado proveniente de aterro sanitário. Em seus estudos os autores variaram os valores de $\operatorname{COV}(0,4$ a 9,4 gDQO/L.dia) e $\operatorname{COE}(0,2$ a 1,9 gDQO/gSSV.dia) através da aplicação de TDH que variaram de 10 a 1,5 dias e concentrações afluentes de 3800 a $15900 \mathrm{mgDQO} / \mathrm{L}$. Dentre as conclusões, cabe destacar que, para a faixa de COV e COE estudadas, a remoção de DQO esteve entre 64 a $85 \%$ e que aproximadamente $83 \%$ da DQO removida era convertida a metano.

RUIZ et al. (2001) aplicaram com sucesso o sistema ASBR para o tratamento de água residuária proveniente de vinícola. Neste estudo, o reator foi operado sob COV e COE de 8,6 gDQO/L.dia e 0,96 gDQO/gSVT.dia, respectivamente, com TDH de 2,2 dias. Para este estudo, os autores alcançaram remoção material orgânico como DQO acima de $98 \%$ e verificaram a possibilidade de automação do reator baseado no controle da velocidade de produção de biogás durante a fase reacional.

SHIZAS \& BAGLEY (2002) estudaram a influencia de parâmetros operacionais, como tempo de enchimento e carregamento orgânico volumétrico, no desempenho de um ASBR em escala de bancada, tratando água residuária de fácil degradação (a base de glicose). Em seus estudos, os autores verificaram que, para valores de COV de 2,1 $\mathrm{kgDQO} / \mathrm{m}^{3}$.dia, a eficiência na remoção de matéria orgânica para amostras filtradas esteve acima de $80 \%$, sendo que, para a DQO remanescentes, 70 - $80 \%$ era composta de propionato. Foi concluído ainda que, para os mesmos valores de COV, os melhores desempenhos são verificados em operações utilizando menores concentrações afluentes e grandes tempos de enchimento, comparado com tempo total de ciclo. 
AGENENT et al. (2002) avaliaram a partida de um ASBR em escala plena (600 $\mathrm{m}^{3}$ ) para o tratamento de água residuária proveniente de pocilga. Utilizando análises de RNA ribossomal 16S (RNAr), para identificação dos microrganismos presentes no lodo, os autores sugerem que a digestão anaeróbia de resíduo de suinocultura se dá, mesmo com concentrações de nitrogênio amoniacal superiores a $3500 \mathrm{mg} / \mathrm{L}$, devido a associação sintrófica entre os organismos oxidantes do acetato e os metanogênicos hidrogenotróficos.

RODRIGUES et al (2003) utilizaram sistema em batelada e batelada alimentada de $5 \mathrm{~L}$, para o tratamento de $2 \mathrm{~L}$ de água residuária simulando esgoto doméstico, com concentração de $500 \mathrm{mgDQO} / \mathrm{L}$, e quatro ciclos por dia. O sistema obteve eficiência média de remoção para amostras filtradas e não filtradas de 78 e $84 \%$ respectivamente.

\subsection{Biomassa Imobilizada em Espuma de Poliuretano}

Em trabalhos clássicos de imobilização de cultura metanogênica em cubos de espuma de poliuretano, como HUYSMAN et al. (1983), FYNN \& WHITMORE (1984) e GIJZEN et al. (1988), ficou evidente a presença de cultura metanogênica enriquecida (longos filamentos de arquea do tipo metanotrix e metanosarcina) e de colonização rápida e heterogênea nesse tipo de suporte. Os autores indicam que a porosidade e, principalmente, o tamanho do poro, apresentam-se como características cruciais para a colonização da espuma e resistência do lodo biológico ao arraste, quando submetidos a sobrecargas hidráulicas, pois nenhum indicativo de adesão física à matriz foi verificado. 
Se a ligação física forte se fizesse presente entre a espuma de poliuretano e as metanogênicas, o fato de a biomassa ser arrastada quando submetido a sobrecarga hidráulica independeria do tamanho de poro apresentado pelas espumas testadas.

Porém, em trabalhos desenvolvidos por VARESCHE et al. (1997), que tinha como objetivo a caracterização da biomassa anaeróbia bem como a estrutura bacteriana dentro das matrizes de espuma de poliuretano através de microscopia eletrônica de varredura e microscopia ótica de florescência e contraste de fase, os autores verificaram três padrões de imobilização da biomassa: micro-grânulos mecanicamente retidos nos poros da espuma de poliuretano, pequenas estruturas multicelulares aderidas por uma estrutura gelatinosa na superfície da espuma além de células individuais aderidas da mesma forma na superfície da espuma. Os autores justificam a discordância com trabalhos anteriores baseando-se na hipótese que culturas mistas de lodo anaeróbio aderem melhor neste tipo de suporte que uma cultura predominantemente metanogênica.

Assim, a utilização de suporte inerte para a fixação de microrganismos tem se mostrado promissora, uma vez que elimina o problema de retenção de sólidos pela fase de sedimentação, reduzindo assim o tempo total do ciclo e ampliando as possibilidades de uso do ASBR. Como a granulação do lodo depende das características da água residuária e da configuração do reator, a utilização de biomassa imobilizada em suporte inerte elimina esta incerteza (ZAIAT et al., 2001).

RATUSZNEI et al. (2000), utilizando um sistema ASBR de 2 L agitado mecanicamente e mantido a $30^{\circ} \mathrm{C}$, atingiu estabilidade operacional após 10 dias de experimento, tratando $0,5 \mathrm{~L}$ de esgoto sanitário sintético (480 mgDQO/L) com 3 ciclos por dia, através da imobilização microbiana em cubos de espuma de poliuretano. A 
eficiência máxima de remoção de DQO foi de $86 \%$, depois de 36 dias de operação em apenas 3 horas após o início do ciclo. No mesmo trabalho, os autores estudaram a influência da velocidade da agitação mecânica no desempenho do reator. Operado com três ciclos diários, o reator era alimentado com $25 \%$ do volume total, com uma água residuária que simulava esgoto doméstico, com concentração de $500 \mathrm{mgDQO} / \mathrm{L}$. Para este trabalho, foi verificada remoção de $83 \%$ para amostras não filtradas, além de redução do período de partida.

Para o estudo da influência da transferência de massa na fase líquida, no desempenho de um ASBR com biomassa imobilizada em cubos espuma de poliuretano de $5 \mathrm{~mm}$ de aresta, CUBAS et al. (2001) utilizaram um reator de 4,2 litros para tratar uma água residuária sintética com concentração de aproximadamente $560 \mathrm{mgDQO} / \mathrm{L}$, utilizando-se 3 ciclos diários. Fazendo uso de três impelidores tipo turbina, estudou-se a faixa de agitação de 300 a $1100 \mathrm{rpm}$. Além de uma remoção média de 78\% na DQO afluente, os autores concluíram que o tempo necessário para alcançar a eficiência de 900 rpm, com uma agitação de $300 \mathrm{rpm}$, seria necessário um tempo 3 vezes maior. Porém, o aspecto de custo com consumo de energia deve ser considerado, quando da escolha da velocidade de agitação a ser empregada.

A influência da recirculação externa no desempenho de um ASBR, com biomassa imobilizada em cubos de espuma de poliuretano $5 \mathrm{~mm}$, foi avaliada através do estudo do efeito de transferência de massa na fase líquida (CAMARGO et al., 2002). O sistema foi alimentado com água residuária sintética contendo glicose como fonte de carbono, com concentração aproximada de $500 \mathrm{mgDQO} / \mathrm{L}$, com três ciclos diários. Os resultados obtidos permitiram concluir que a eficiência na remoção de matéria orgânica 
aumentou de 83 para 95\%, para amostras do efluente não filtrado, quando a recirculação foi implementada, como conseqüência do melhor contato entre substrato e biomassa.

\subsection{Considerações Finais}

A literatura apresentada mostra a aplicação do reator anaeróbio operado em batelada, com imobilização microbiana na forma de grânulos, para o tratamento de águas residuárias com altas concentrações de matéria orgânica e sólidos voláteis, como o efluentes proveniente de suinocultura (pocilga), o percolado de aterro sanitário e o efluente proveniente de industrias que beneficiam o leite. Para estes casos, os reatores são operados com grandes valores de COV, porém apresentam problemas na retenção de microrganismos e queda na eficiência de conversão de substrato orgânico à metano. Atualmente, estudos crescentes mostram a aplicação do sistema ASBR para tratamento de águas residuárias com baixas concentrações de matéria orgânica.

A imobilização microbiana na forma de biofilme, aderido à espuma de poliuretano, elimina o problema de incerteza quanto ao fenômeno de granulação e o período necessário para a sedimentação do lodo, além de proporcionar maior resistência a cargas tóxicas aos microrganismos associados. Dessa forma, o aumento da concentração de biomassa no interior do reator amplia o leque de utilização do sistema para aplicação de grandes carregamentos orgânicos e utilização no tratamento de substâncias tóxicas. 
Entretanto, ao contrário dos sistemas com microrganismos auto-imobilizados na forma de grânulos ou flocos, pouco se sabe a respeito dos aspectos fundamentais e operacionais quanto à utilização do reator operado em batelada seqüencial e suporte inerte para fixação do biofilme. Poucos trabalhos investigaram o COV máximo que pode ser aplicado no reator operado em batelada seqüencial e os efeitos da possível sobrecarga orgânica em seu desempenho.

Desta forma, o presente trabalho visa estudar a influência do aumento de cargas orgânicas na eficiência e estabilidade de um reator anaeróbio operado em batelada seqüencial com microrganismos imobilizados em espuma de poliuretano. 


\section{CAPÍTULO 4}

\section{MATERIAIS E MÉTODOS}

\subsection{Materiais}

\subsubsection{Configuração do Sistema ASBR com Biomassa Imobilizada}

O sistema proposto tem como base o apresentado por RATUSZNEI et al. (2000); e consta de um reator de acrílico com volume total de 6,3 litros com $20 \mathrm{~cm}$ de diâmetro e $20 \mathrm{~cm}$ de altura, sendo os últimos três centímetros reservados ao "head-space", com aproximadamente 0,9 litro. Este reator é composto de três partes desmontáveis, todas de acrílico, que são: corpo do reator propriamente dito; tampa munida de orifícios para as condições de carregamento de afluente e amostragem; e fundo do reator com formato levemente cônico para que o efluente flua facilmente em direção do tubo de descarga. Todas essas partes são unidas com flanges e borrachas de vedação.

Dentro deste reator foi acomodado um cesto de aço inox 310 completamente vazado com tela do mesmo material, com $16 \mathrm{~cm}$ de altura e 19,5 cm de diâmetro, para alocar os cubos de espuma de poliuretano que servem como suporte inerte para a 
imobilização microbiana. Este cesto é provido de um espaço em seu centro de $7 \mathrm{~cm}$ de diâmetro para que se faça a agitação mecânica. O cesto é apoiado no fundo do reator por suportes que o deixa à altura de um centímetro do fundo para facilitar a descarga do efluente e evitar acúmulo de sólidos.

A agitação mecânica do meio reacional, promovida por um motor de indução marca Marconi ${ }^{\circledR}$ modelo MA 259, foi implementada por um impelidor tipo turbina (padrão Rushton) e dimensões de $6 \mathrm{~cm}$ de diâmetro externo e com 6 pás planas pás de $15 \times 15 \mathrm{~mm}$ de arestas. O impelidor dista $6 \mathrm{~cm}$ do fundo do reator.

O esquema cotado da montagem experimental, assim como as fotografias do sistema em operação, reator com cesto de aço inox e detalhes do cesto de aço inox e impelidor, são apresentados nas FIGURAS 4.1 a 4.4. O reator é apresentado com vistas e cortes no APÊNDICE I, nas FIGURAS I.1 a I.4.

A montagem experimental foi inserida em uma câmara com temperatura mantida a aproximadamente $30{ }^{\circ} \mathrm{C}$, graças a um sistema de aquecimento composto por resistências, além de um sensor e controlador de temperatura da marca Novus ${ }^{\circledR}$, modelo N480.

A alimentação e descarga foram realizadas por bombas tipo diafragma marca ProMinent ${ }^{\circledR}$, modelos $\propto$ e $\beta 5$, auxiliadas por um sistema de automação composto por temporizadores da marca Grasslin ${ }^{\circledR}$ modelo Lógica 500. 


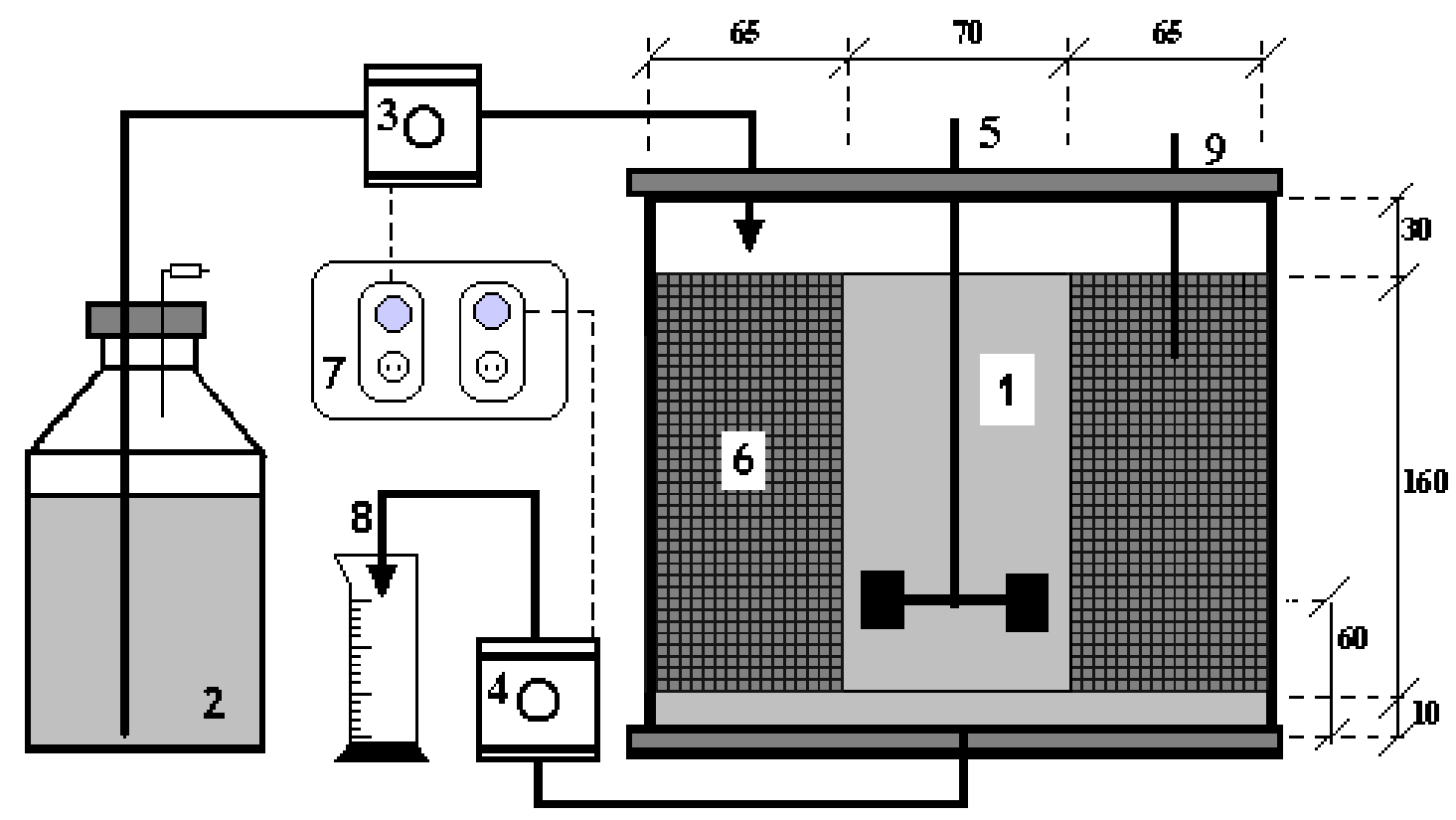

FIGURA 4.1 - Esquema do reator anaeróbio operado em batelada seqüencial contendo biomassa imobilizada [Notação (cotas em milímetros): (1) Tanque de reação, (2) Substrato esterilizado, (3) Bomba de alimentação tipo diafragma, (4) Bomba de descarga tipo diafragma (5) Agitador mecânico, (6) Cesto de aço inoxidável contendo espumas com células imobilizadas, (7) Temporizadores, (8) Efluente tratado e (9) Termômetro]. 


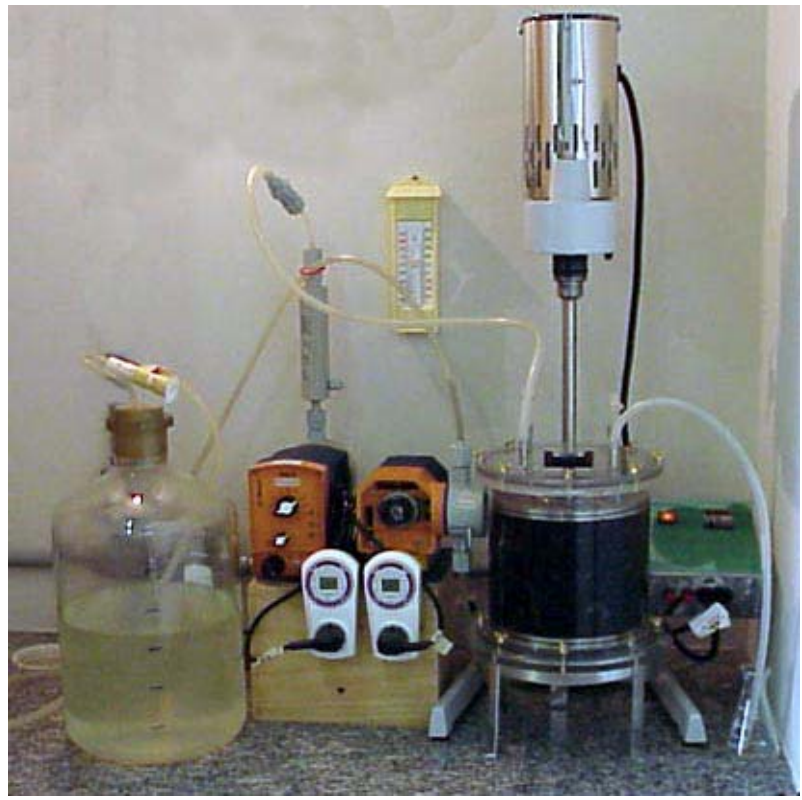

FIGURA 4.2 - Montagem experimental do ASBR com microrganismos imobilizados em cubos de espuma de poliuretano e tratando água residuária sintética.

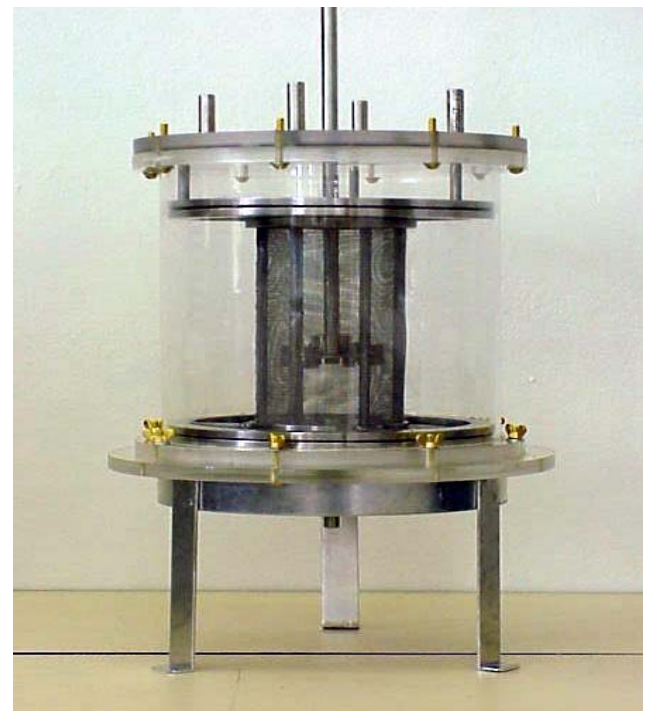

FIGURA 4.3 - Reator montado mostrando detalhes do "head-space", do cesto e do impelidor. 

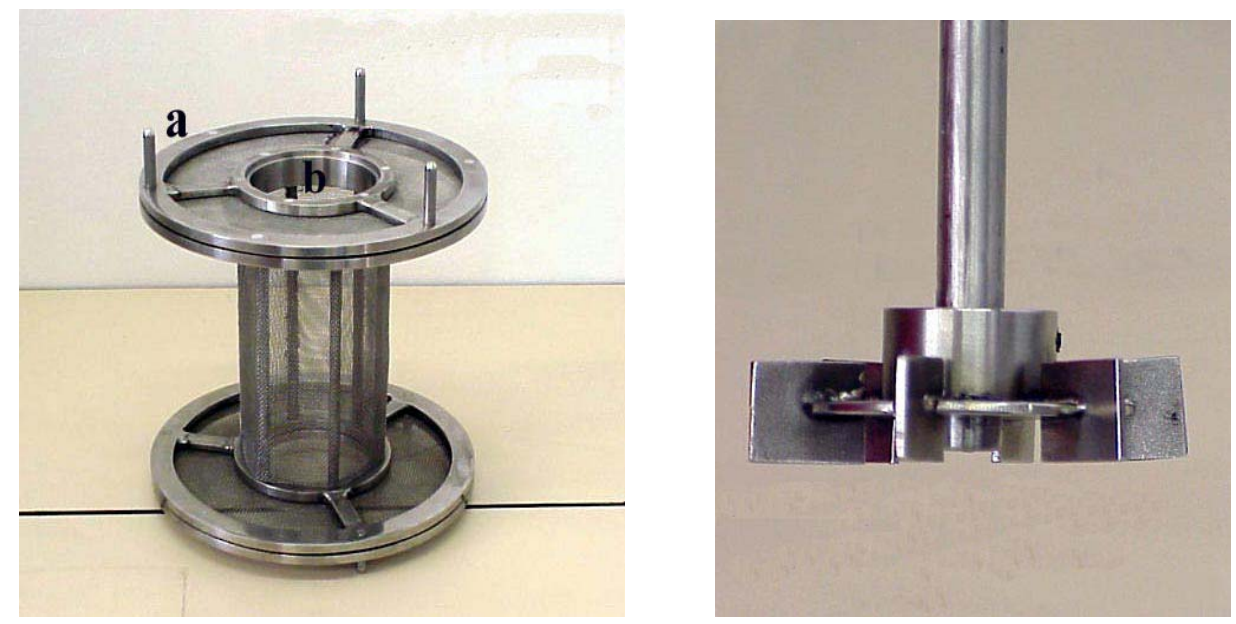

FIGURA 4.4 - A esquerda, cesto de aço inox 316 com tela, com $16 \mathrm{~cm}$ de altura e 19,5 cm de diâmetro (a) maior e $7 \mathrm{~cm}$ de diâmetro (b) menor; e a direita o impelidor tipo turbina com $6 \mathrm{~cm}$ de diâmetro, com 6 pás planas de 15x15 mm de lado.

\subsubsection{Suporte de Imobilização da Biomassa Anaeróbia}

O suporte inerte utilizado na imobilização da biomassa consta de cubos de poliuretano (densidade de $23 \mathrm{Kg} / \mathrm{m}^{3}$ e porosidade máxima de $95 \%$ ) com 1,0 cm de aresta. Esta espuma foi produzida pela empresa Emil Indústria e Comércio - Elói Mendes, MG e foi confeccionada sem a adição de corantes ou aditivos.

\subsubsection{Inóculo}

O inóculo utilizado em todos os experimentos foi proveniente de um reator anaeróbio de manta de lodo e escoamento ascendente (UASB) na forma granular, que 
trata, com bons resultados, água residuária de abatedouro de aves (Dacar Industrial S.A.), com sede em Tietê - SP.

\subsection{4. Água Residuária Sintética}

Com base na composição média de esgoto domiciliar apresentado na literatura (TORRES, 1992), a água residuária sintética utilizada como substrato foi constituída por fontes de carbono, formada por carboidratos de fácil e difícil degradação (nas formas de celulose, sacarose e amido), fonte de proteína (na forma de extrato de carne), lipídeos (na forma de óleo de soja); micronutrientes (solução de sais) para o crescimento microbiológico balanceado, bicarbonato de sódio para manter o tamponamento do meio e detergente para que haja a emulsão do óleo.

Para se assegurar que as características da água residuária sintética não mudassem durante os experimentos pela ação de microrganismos presentes na água de diluição, e que os constituintes dispostos para formá-la estivessem totalmente dissolvidos, todo o meio afluente foi esterilizado em autoclave vertical da marca Phoenix modelo AV 75. As características da água residuária sintética são mostradas nas TABELAS 4.1 e 4.2 .

Os valores apresentados na TABELA 4.2 são baseados na demanda química de oxigênio da ordem de $500 \mathrm{mg} / \mathrm{L}$. A água residuária foi preparada nas concentrações de 500,10001500 e $2000 \mathrm{mgDQO} / \mathrm{L}$, sendo os outros compostos adicionados proporcionalmente. 
TABELA 4.1 - Descrição da água residuária utilizada (TORRES, 1992).

\begin{tabular}{ccc}
\hline Composto Orgânico & DQO $(\%)$ & Constituinte \\
\hline Proteínas & 50 & extrato de carne \\
Carboidratos & 40 & sacarose,amido, celulose \\
Lipídios & 10 & óleo de soja \\
\hline
\end{tabular}

TABELA 4.2 - Composição da água residuária utilizada (TORRES, 1992).

\begin{tabular}{|c|c|}
\hline Composto & Concentração (mg/L) \\
\hline \multicolumn{2}{|l|}{ Carboidratos } \\
\hline Sacarose & 35 \\
\hline Amido & 114 \\
\hline Celulose & 34 \\
\hline \multicolumn{2}{|l|}{ Proteínas } \\
\hline Extrato de carne & 208 \\
\hline \multicolumn{2}{|l|}{ Lipídios } \\
\hline Óleo de soja* & 51 \\
\hline \multicolumn{2}{|l|}{ Tampão } \\
\hline $\mathrm{NaHCO} 3$ & 200 \\
\hline \multicolumn{2}{|l|}{ Sais } \\
\hline $\mathrm{NaCl}$ & 250 \\
\hline $\mathrm{MgCl} 2.6 \mathrm{H} 2 \mathrm{O}$ & 7 \\
\hline $\mathrm{CaCl} 2.2 \mathrm{H} 2 \mathrm{O}$ & 4,5 \\
\hline
\end{tabular}




\subsection{Métodos}

\subsubsection{Composição do Biogás}

Para caracterização do biogás produzido no processo anaeróbio, foi utilizada a cromatografia gasosa, utilizando-se Cromatógrafo HP 6890 com uma coluna empacotada Porapack Q, injetor empacotado com controle eletrônico de pressão e detector de condutividade térmica com controle eletrônico de pressão.

As condições operacionais do cromatógrofo foram:

- Temperatura de injeção da amostra: $60,0^{\circ} \mathrm{C}$;

- Gás de arraste: $\mathrm{H}_{2}$;

- Vazão do gás de arraste (CNTP): 50,0 mL/h;

- Vazão do make-up (CNTP): 2,5 mL/h;

- Temperatura do injetor: $60,0{ }^{\circ} \mathrm{C}$;

- Temperatura do detector: $160,0{ }^{\circ} \mathrm{C}$;

- Temperatura da coluna: $35,0{ }^{\circ} \mathrm{C}$;

- Volume de amostra: 1,0 mL.

\subsubsection{Análises Físico-Químicas}

Os métodos físico-químicos utilizados foram aqueles normalmente empregados em sistemas anaeróbios para a quantificação da estabilidade e eficiência do tratamento, 
considerando-se amostras do afluente e efluente, como: concentração de matéria orgânica filtrada e não filtrada, como DQO, concentração de ácidos voláteis totais, concentração de alcalinidade (dividida em total, parcial, intermediária e a bicarbonato), sólidos totais e voláteis totais, sólidos em suspensão totais e em suspensão voláteis, além do pH. As metodologias empregadas estão de acordo com o Standard Methods for Examination of Water and Wastewater (1995), considerando-se também o método proposto por RIPLEY et al. (1986) na determinação da alcalinidade.

Neste ponto, cabe uma importante colocação a se fazer a respeito da relação concentração de ácidos voláteis totais e alcalinidade a ácidos voláteis totais. Em estudo feitos por DILALLO \& ALBERTSON (1961) foi proposto que, para alcalinidade a ácidos voláteis totais medidos por titulometria até $216 \mathrm{mgHAc} / \mathrm{L}$, a relação entre estas duas grandezas são iguais e que, para valores de alcalinidade maiores que 216 mgHAc/L, a concentração de ácidos voláteis totais é igual a uma vezes e meia a de alcalinidade a ácidos voláteis.

\subsubsection{Análises Microbiológicas}

As análises microbiológicas do lodo foram realizadas através de microscopia ótica comum e microscopia ótica de contraste de fases por fluorescência, utilizando microscópio Olympus modelo BH2. 


\subsection{Procedimento Experimental}

\subsubsection{Imobilização em Suporte Inerte}

A metodologia de imobilização da biomassa em suporte inerte foi análoga à apresentada por ZAIAT et al. (1994). A espuma de poliuretano cortada em cubos de 1 $\mathrm{cm}$ de aresta, foi colocada em contato com o lodo anaeróbio adicionado e misturando até que toda a espuma estivesse em contato com a suspensão. O lodo granular foi previamente macerado, utilizando uma peneira para a quebra dos grânulos, para facilitar a aderência microbiana no material suporte na forma de biofilme. Decorrido o período de contato de $2 \mathrm{~h}$, os sólidos fracamente aderidos foram lavados para fora do reator utilizando-se água residuária sintética. O lodo original utilizado possuía as seguintes características, em termos de sólidos: 0,0048 g SVT/g lodo, e 0,026 g ST/g lodo.

A FIGURA 4.5 apresenta a característica da espuma antes e depois da inoculação com o lodo anaeróbio.

\subsubsection{Procedimento Operacional}

Os ensaios para a verificação da influência da carga orgânica volumétrica foram iniciados com concentração afluente de $500 \mathrm{mgDQO} / \mathrm{L}$. A segunda e terceira condições operacionais foram realizadas alimentando-se o sistema com uma água residuária com concentração de matéria orgânica de 1000 e 2000 mgDQO/L. 


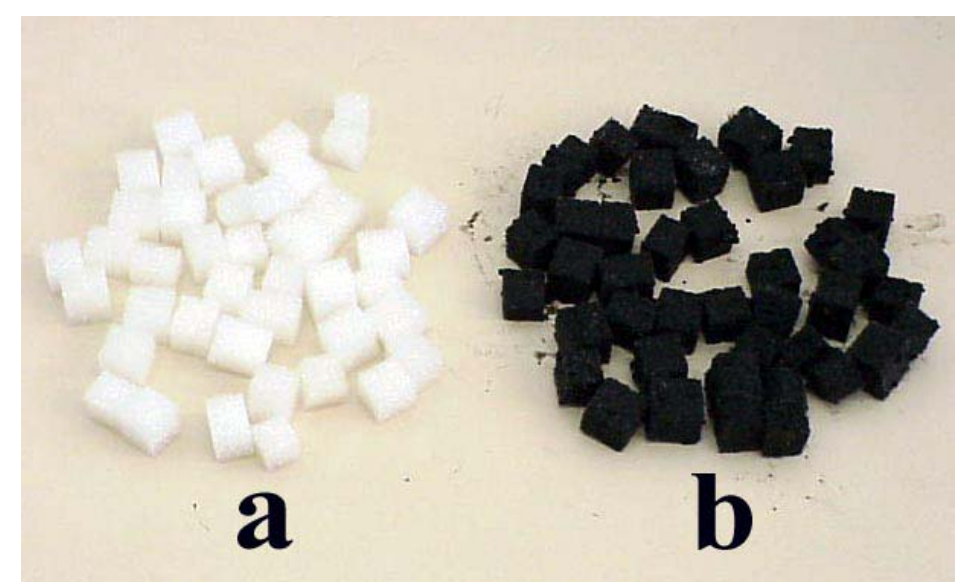

FIGURA 4.5 - Detalhe da dos cubos de espuma de poliuretano de $1 \mathrm{~cm}$ de lado (a) antes e (b) depois da inoculação com lodo.

Para as três primeiras condições operacionais, o tempo de batelada empregado foi de $8 \mathrm{~h}$ distribuídos da seguinte forma: 10 min para alimentação, 10 min para descarga e o restante para a reação. Entre dois ciclos consecutivos foi estabelecido um tempo de 1 min, como segurança para sincronismo de operação das duas bombas usadas na alimentação e descarga, controlados por temporizadores.

Com os dados dos parâmetros analisados para a terceira condição operacional, a quarta condição foi adaptada para operar com ciclos de 12 horas, alimentando-se o sistema com uma água residuária sintética de 2000 mgDQO/L.

Para a quinta e sexta condições operacionais, mantendo-se o tempo de ciclo de 12 horas, alimentou-se o sistema com concentrações de 1500 e 1000 mgDQO/L, respectivamente. Os tempos reservados para alimentação e drenagem do efluente foram os mesmos que os aplicados para a batelada de $8 \mathrm{~h}$, sendo o restante destinado à fase reacional. 
Para todas as etapas operacionais, aproximadamente $2000 \mathrm{~mL}$ foram adicionados no início de cada nova batelada, de forma que o reator era descarregado e carregado totalmente. O volume remanescente no reator era composto de material suporte com microrganismos aderidos. A agitação foi fixada em $500 \mathrm{rpm}$, conforme ensaios realizados em trabalhos anteriores, e a temperatura mantida em $30^{\circ} \mathrm{C} \pm 1$ para todas as condições experimentais. A TABELA 4.3 abaixo apresenta as condições operacionais na ordem de sua execução, além do número de dias utilizado para cada etapa de operação. A mudança de condição de alimentação apenas aconteceu após o efluente do reator alcançar o equilíbrio em termos de estabilidade dos valores de efluente para as amostras filtradas e eficiência na conversão de substrato orgânico.

TABELA 4.3. - Condições operacionais implementadas para estudo de aumento de carga orgânica volumétrica.

\begin{tabular}{cccc}
\hline Condição Operacional & $\begin{array}{c}\text { Concentração afluente } \\
(\operatorname{mgDQO} / \mathrm{L})\end{array}$ & $\begin{array}{c}\text { Tempo de ciclo } \\
(\mathrm{h})\end{array}$ & $\begin{array}{c}\text { Tempo de operação } \\
(\mathrm{d})\end{array}$ \\
\hline $1^{\circ}$ & 500 & 8 & 48 \\
$2^{\circ}$ & 1000 & 8 & 67 \\
$3^{\circ}$ & 2000 & 8 & 20 \\
$4^{\circ}$ & 2000 & 12 & 35 \\
$5^{\circ}$ & 1500 & 12 & 31 \\
$6^{\circ}$ & 1000 & 12 & 31 \\
\hline
\end{tabular}




\subsubsection{Monitoramento}

Para cada condição operacional, o sistema ASBR foi acompanhado por um determinado período até que as variáveis monitoradas não apresentassem grandes variações de uma batelada para a outra. Para a primeira condição, o sistema foi acompanhado durante 48 dias, sendo monitorado sob condições estáveis nos últimos 22 dias. Na segunda condição, o sistema foi acompanhado por um período maior, devido a complicações operacionais. Foram 67 dias de operação, sendo os últimos 33 dias observada condição de estabilização da eficiência de remoção de matéria orgânica. Para a terceira condição operacional, o sistema foi acompanhado por 20 dias sob monitoramento. Para a quarta condição operacional, o sistema foi operado por 35 dias, dos quais os últimos 10 dias foram monitorados sob condições estáveis. A quinta e sexta condições experimentais foram monitoradas por 31 dias, sendo observada estabilidade operacional nos últimos 24 dias.

A concentração das frações de metano e dióxido de carbono presentes no biogás, obtidas por amostragem $15 \mathrm{mim}$ antes da etapa de descarga do efluente tratado e analisadas por cromatografia gasosa, foram obtidas apenas durante as realizações dos perfis de biogás. Cabe observar que os dados da fração molar dos gases foram calculados assumindo-se a hipótese de que o biogás fosse composto somente por metano e dióxido de carbono.

A TABELA 4.4 apresenta a freqüência com que os parâmetros eram amostrados ao longo das condições operacionais aplicadas. 
TABELA 4.4 - Freqüência dos parâmetros analisados durante os ciclos operacionais para as três primeiras condições operacionais.

\begin{tabular}{cc}
\hline Parâmetro & Freqüência \\
\hline $\mathrm{C}_{\mathrm{EF}} \mathrm{e} \mathrm{C}_{\mathrm{ET}}$ & Diariamente \\
$\mathrm{C}_{\mathrm{A}}$ & Quando da abertura de meio de cultivo \\
$\mathrm{AB}, \mathrm{AVT}$ e pH & Afluente $=2$ x por semana \\
$\mathrm{ST}, \mathrm{SVT}, \mathrm{SST}, \mathrm{SVT}$ & Efluente $=3 \times$ por semana \\
\hline
\end{tabular}

\subsection{4.- Perfis das Variáveis Monitoradas ao Longo da Batelada}

Para cada condição operacional, após não se constatar diferenças significativas no valor monitorado para a concentração de matéria orgânica para amostras filtradas e na concentração de alcalinidade a ácidos voláteis e bicarbonato, foram obtidos perfis ao longo do ciclo das concentrações de substrato efluente para amostras filtradas, dos ácidos voláteis totais, de alcalinidade a bicarbonato, de $\mathrm{pH}$ e das concentrações de metano e dióxido de carbono. Estes perfis permitiram melhor compreensão das rotas metabólicas além do cálculo dos parâmetros cinéticos da degradação do substrato.

O perfil de concentração de matéria orgânica filtrada efluente, expressa como DQO, foi realizada coletando-se alíquotas de $7 \mathrm{~mL}$ com duas estratégias de coleta: para operações com tempo de ciclo de 8 horas (primeira, segunda e terceira condições operacionais), amostras foram retiradas em intervalos de tempos de 15 min nas três primeiras horas e de 30 min no tempo restante ao ciclo. Para operações com tempo de ciclo de 12 hora (quarta, quinta e sexta condições operacionais), amostras foram 
retiradas em intervalos de tempo de 20 min nas três primeiras horas, de 30 min nas três horas seguintes e de 1 hora para as últimas seis horas. Tal estratégia foi necessária para respeitar o limite de volume amostrado, que não deve ultrapassar $10 \%$ do volume do reator.

Para o perfil de substrato, a amostragem foi feita em duplicata para a primeira, quarta, quinta e sexta condições, triplicata para a segunda e uma única vez para a terceira condição. O termo duplicata e triplicata são referente, respectivamente, a amostragem em três e dois dias diferentes.

Para o perfil de alcalinidade a bicarbonato e concentração de ácidos voláteis totais, foram feitas amostragens em duplicata para a primeira, quarta, quinta e sexta condições operacionais, triplicata para a segunda condição e uma única vez para a terceira condição. Para todos os casos, foram retiradas alíquotas de $20 \mathrm{~mL}$ de modo a não retirar um volume superior a $10 \%$ de meio contido dentro do reator.

Para os ensaios com duração de 8 horas, as amostras foram retiradas em intervalos de tempo de 30 min durante a batelada. Para os ensaios com duração de 12 horas, as amostras foram retiradas em intervalos de tempo de 40 min nas duas primeiras horas, uma hora para as tres horas seguintes e uma hora e mais para as 7 horas seguintes.

Uma exceção foi feita para a terceira condição, na qual um único perfil de alcalinidade a bicarbonato e concentração de ácidos voláteis totais foi realizado, sendo retiradas alíquotas de $20 \mathrm{~mL}$ a cada 40 min nas primeiras quatro horas e a cada 1 hora no tempo restante da batelada.

Os perfis de concentração de metano e dióxido de carbono no "head-space" do reator, para análise da composição do biogás foram realizadas através da retirada de 1 
$\mathrm{mL}$ do biogás em intervalos de $30 \mathrm{~min}$ ao longo da batelada, com seringa marca Supelco de $1 \mathrm{~mL}$ e injetado em cromatógrofo gasoso HP 6890 com detector de ionização de chama. As amostragens foram feitas em triplicata para a segunda condição, uma única vez para a terceira e quinta condições e duplicata para a quarta e sexta condições operacionais. Para a primeira condição, o perfil de biogás não foi realizado devido a problemas com a calibração do cromatógrafo.

\subsection{5.- Análise de Sólidos nas Espumas de Poliuretano}

Ao final de cada fase de operação, amostras de espuma de poliuretano foram retiradas, para análise microbiológica e de sólidos. Nesse momento, foi registrada a massa total de espuma inoculada $\left(\mathrm{M}_{\mathrm{INOC}}\right)$ dentro do reator. Através das espumas retiradas de pontos diferentes do reator, foram calculadas as concentrações de sólidos totais $\left(\mathrm{C}_{\mathrm{ST}}\right)$ e voláteis totais $\left(\mathrm{C}_{\mathrm{SVT}}\right)$, por massa de espuma limpa, adotando-se os seguintes procedimentos: a amostra de espuma com massa conhecida passou por sucessivas lavagens com água destilada e auxílio de espátula para separar a biomassa da espuma. Dessa forma, o material líquido, juntamente com a biomassa, foram transferidos para um cadinho de porcelana para análise de sólidos totais (estufa a $105^{\circ} \mathrm{C}$ ) e sólidos voláteis totais (mufla a $550^{\circ} \mathrm{C}$ ). Em outro cadinho, a espuma limpa foi secada até peso constante (estufa a $105^{\circ} \mathrm{C}$ ). Com posse desses valores, calculou-se a massa de sólidos totais $\left(\mathrm{C}_{\mathrm{ST}}\right)$, a massa de sólidos voláteis totais $\left(\mathrm{C}_{\mathrm{SVT}}\right)$ por grama de espuma limpa, e a relação entre a massa de espuma limpa e espuma inoculada no reator $(\gamma)$. 


\subsection{Fundamentos Teóricos}

\subsubsection{Parâmetros Operacionais}

Dois parâmetros muito utilizados para caracterizar os sistemas de tratamento de águas residuárias são tempo de detenção hidráulico (TDH), que relaciona grandezas como volume de reator e vazão afluente ao sistema e é expresso como unidade de tempo, e carga orgânica volumétrica (COV), que representa a vazão mássica de matéria orgânica tratada por volume de reator, expresso como concentração de substrato por unidade de tempo, por exemplo, mgDQO/L dia. Porém, estes parâmetros são mais usuais para sistemas contínuos de tratamento.

Em reatores descontínuos, como o ASBR, estes parâmetros podem parecer inadequados. A importância da quantificação dos carregamentos hidráulico e orgânico se faz para efeito de comparação com sistemas contínuos e validação de sua aplicação industrial ou municipal. Assim sendo, os parâmetros foram adaptados, como mostrado nas EQUAÇÕES 4.1 e 4.2.

$$
\begin{aligned}
& T D H=\frac{t_{C}}{V_{A L I}} V \\
& C O V=\frac{V_{A L I} C_{A}}{t_{C} V}
\end{aligned}
$$


Nas expressões 4.1 e 4.2 , os termos representam:

$\mathrm{V}$ - volume útil do reator $(\mathrm{L})$;

$\mathrm{V}_{\mathrm{ALI}}$ - volume de água residuária alimentada por ciclo (L);

$\mathrm{C}_{\mathrm{A}}$ - concentração do substrato no afluente $(\mathrm{mgDQO} / \mathrm{L})$;

$\mathrm{t}_{\mathrm{C}}$ - tempo de duração do ciclo (dia).

Entretanto, para o caso aplicado neste estudo, além dos parâmetros apresentados, outra metodologia será aplicada para seu cálculo. Para reatores com biomassa imobilizada em suporte inerte, descontou-se o volume ocupado pela espuma de poliuretano, inoculada com microrganismos, do volume total do reator, Dessa forma o volume útil do reator $(\mathrm{V})$ é igual ao volume de meio alimentado $\left(\mathrm{V}_{\mathrm{ALI}}\right)$ em cada ciclo (CAMARGO, 2000). Assim sendo, a carga orgânica volumétrica $\left(\mathrm{COV}_{\mathrm{IM}}\right)$ e o tempo de detenção hidráulico $\left(\mathrm{TDH}_{\mathrm{IM}}\right)$, para sistemas com biomassa imobilizada em material suporte inerte, são representados nas EQUAÇÕES 4.3 e 4.4.

$$
\begin{aligned}
& T D H_{I M}=t_{C} \\
& C O V_{I M}=\frac{C_{A}}{t_{C}}
\end{aligned}
$$

Outro parâmetro importante, carga orgânica específica (COE), expresso como massa de substrato por massa de microrganismos por unidade de tempo, por exemplo, 
mgDQO/mgSVT.dia, foi considerado. Tal relação foi extraída do trabalho apresentado por RUIZ et al. (2001) e pode ser observada na EQUAÇÃO 4.5.

$$
C O E=\frac{V_{A L I} C_{A}}{t_{C} X}
$$

$\mathrm{Na}$ equação 4.5, o termo que ainda não foi esclarecido representa:

$\mathrm{X}$ - quantidade de biomassa aderida em suporte inerte dentro do reator (mgSVT).

A EQUAÇÃO 4.6 apresenta o cálculo da quantidade média de biomassa dentro do reator $(\mathrm{X})$, na qual $\gamma$ representa a relação entre a massa de espuma limpa e a massa de espuma inoculada.

$$
X=\gamma M_{I N O C} C_{S V T}
$$

$\mathrm{Na}$ equação 4.6, os valores representam:

$\gamma$ - relação entre a massa de espuma limpa e de espuma inoculada (g espuma/ $\mathrm{g}$ de espuma inoculada);

$\mathrm{M}_{\mathrm{INOC}}$ - massa total de espuma inoculada no reator ( $\mathrm{g}$ espuma inoculada);

$\mathrm{C}_{\mathrm{SVT}}$ - massa de SVT por massa de espuma limpa (mg SVT/g espuma limpa). 


\subsubsection{Cálculo das Eficiências de Conversão}

Para análise do desempenho do reator para conversão do material orgânico do sistema ASBR, a eficiência de remoção de matéria orgânica efluente para amostras filtradas e não filtradas são estimadas pelas EQUAÇÕES 4.7 e 4.8 com os valores monitorados ao longo dos ciclos de operação.

$$
\begin{aligned}
& \varepsilon_{E F}=\left(\frac{C_{E F}-C_{A}}{C_{A}}\right) 100 \\
& \varepsilon_{E T}=\left(\frac{C_{E T}-C_{A}}{C_{A}}\right) 100
\end{aligned}
$$

Nas expressões 4.7 e 4.8 , os termos representam:

$\mathrm{C}_{\mathrm{A}}$ - concentração média de substrato alimentado (mgDQO/L);

$\mathrm{C}_{\mathrm{ET}}$ - concentração de substrato efluente para amostras não filtradas (mgDQO/L);

$\mathrm{C}_{\mathrm{EF}}$ - concentração de substrato efluente para amostras filtradas (mgDQO/L);

$\varepsilon_{\mathrm{EF}}$ - eficiência de remoção de matéria orgânica para amostras filtradas (\%);

$\varepsilon_{\mathrm{ET}}$ - eficiência de remoção de matéria orgânica para amostras não filtrada (\%).

A eficiência de remoção obtida a partir do perfil de um ciclo operacional, é estimada pela EQUAÇÃO 4.9, a qual considera o efeito de diluição inicial, propiciado 
pelo liquido remanescente retido nas espumas dentro do reator, ou seja, a concentração inicial no reator.

$$
\varepsilon_{P}=\left(\frac{C_{E F}^{t=0}-C_{E F}^{t=t}}{C_{E F}^{t=0}}\right) 100
$$

$\mathrm{Na}$ expressão 4.9, os termos representam:

$C_{E F}^{t=0}$ - concentração de substrato efluente nas amostras filtradas após a alimentação do reator, e no tempo zero da condição de reação (mgDQO/L);

$C_{E F}^{t=t}$ - concentração de substrato efluente para amostras filtradas, em um tempo qualquer de durante um ciclo operacional (mgDQO/L);

$\varepsilon_{P}$ - eficiência de remoção da matéria orgânica referente ao perfil (\%).

Os valores da concentração de matéria orgânica para amostras filtradas, utilizados no cálculo da eficiência de remoção da matéria orgânica para o perfil, foram normalizados. Considerando-se, como base, a média das concentrações no tempo zero para os ciclos analisados e as eficiências relativas a cada amostragem para todo o ciclo, as concentrações de matéria orgânica corrigidas, para amostras filtradas, foram calculadas. 


\subsubsection{Perfis de Conversão de Matéria Orgânica ao Longo da Batelada}

$\mathrm{Na}$ determinação dos coeficientes cinéticos para a degradação do substrato, o balanço material aplicado ao reator isotérmico, agitado, com volume constante e operado em batelada resultou na EQUAÇÃO 4.10:

$$
\frac{d C_{S}}{d t}=-r_{S}
$$

Na expressão 4.10, os termos representam:

$\mathrm{r}_{\mathrm{S}}$ - velocidade de consumo de substrato (mgDQO/L.h);

$\mathrm{C}_{\mathrm{S}}$ - concentração de substrato no efluente para amostras filtradas (mgDQO/L);

$\mathrm{t}$ - tempo de batelada (h).

A velocidade de consumo de substrato pode ser representada por uma série de modelos já estudados na literatura. Para reatores biológicos, a velocidade de consumo de substrato é proporcional à velocidade de crescimento microbiano, que pode ser representada pelo modelo cinético de Monod. Para esse caso, a velocidade específica de crescimento se torna proporcional à concentração do substrato para concentrações muito baixas de substrato, sendo simplificado a um modelo de primeira ordem. Considerandose que a concentração de microrganismos permanece praticamente constante durante a batelada, fato devido ao metabolismo anaeróbio ser bastante lento, a introdução de um coeficiente cinético aparente $\left(k_{1}\right)$, que incorpora os termos cinéticos intrínsecos, além 
das resistências à transferência de massa interna e externa, pode ser perfeitamente aplicado, conforme EQUAÇÃO 4.11:

$$
r_{S}=k_{1} C_{S}
$$

Foi verificada, em trabalhos anteriores, a existência de uma concentração de substrato residual $\left(\mathrm{C}_{\mathrm{SR}}\right)$, que representa os valores da concentração de substrato filtrado quando a velocidade da reação torna-se zero. Dessa forma, o balanço material do reator pode ser reescrito na forma da EQUAÇÃO 4.12:

$$
\frac{d C_{S}}{d t}=-k_{1}\left(C_{S}-C_{S R}\right)
$$

Na equação acima, os termos que ainda não foram esclarecidos representam:

$\mathrm{k}_{1}$ - constante cinética aparente $\left(\mathrm{h}^{-1}\right)$;

$\mathrm{C}_{\mathrm{SR}}$ - concentração residual de substrato efluente (mgDQO/L).

Fazendo uso da condição inicial $\left(\mathrm{t}=0, \mathrm{C}_{\mathrm{S}}=\mathrm{C}_{\mathrm{So}}\right)$ e integrando a equação 4.12 , obtem-se a EQUAÇÃO 4.13, que descreve o consumo de substrato durante a batelada.

$$
C_{S}=C_{S R}+\left(C_{S o}-C_{S R}\right) \exp \left(-k_{1} t\right)
$$


Dessa forma, obteve-se o valor da constante cinética aparente $\left(k_{1}\right)$ através de um ajuste não linear do modelo cinético de primeira ordem apresentado anteriormente, aos valores experimentais da concentração de substrato filtrado obtidos nos perfis, utilizando-se para tal, o aplicativo Microcal Origin versão 6.1 pelo método numérico de Levenberg-Maquardt.

Para verificação de melhores ajustes do modelo não lineares aos pontos experimentais do perfil de concentração de substrato para amostras filtradas, foram utilizadas duas formas de tratamento dos dados: (a) pelo ajuste do modelo aos dados experimentais, mantendo-se os valores da concentração de substrato residual $\left(\mathrm{C}_{\mathrm{SR}}\right)$ constante e iguais as médias dos valores observados ao final do perfil; e (b) estimativa de ambos, parâmetro cinético aparente $\left(\mathrm{k}_{1}\right)$ e concentração de substrato residual $\left(\mathrm{C}_{\mathrm{SR}}\right)$, pelo ajuste do modelo aos dados experimentais. 


\section{CAPÍTULO 5}

\section{RESULTADOS E DISCUSSÃO}

\subsection{Concentração Afluente de 500 mgDQO/L e Ciclos de 8h}

Na primeira condição de trabalho, o reator foi operado e monitorado durante um período de 48 dias, alcançando remoções máximas de matéria orgânica, no fim de ciclo, após o $26^{\circ}$ dia de operação, quando não mais se observou mudança brusca nas variáveis monitoradas. Dessa forma, pode-se acompanhar o sistema operando há 22 dias sob condições estáveis.

Os valores originais para construção da tabelas e figuras apresentadas nessa seção encontram-se nas TABELAS II.1 e II.2 do APÊNDICE II, TABELAS III.1 e III.2 do APÊNDICE III e TABELAS IV.1 e IV.2 do APÊNDICE IV.

A TABELA 5.1 resume os valores médios das variáveis monitoradas médias afluentes, referentes a todos os valores obtidos, enquanto que as médias efluentes são referentes aos últimos 22 dias de operação. Para essa condição, não foram obtidas as concentrações de metano e dióxido de carbono no "head-space" do reator devido a problemas com a calibração do cromatógrafo. 
Os parâmetros operacionais foram calculados de acordo com as equações apresentadas no capítulo anterior e estão apresentadas na TABELA 5.2. Nessa etapa, as medidas da quantidade de espumas totais inoculados no reator, assim como as concentrações de sólidos totais e voláteis totais por espuma limpa não foram feitas. Porém, para efeito de cálculo, os valores da segunda condição foram utilizados nos cálculos da carga orgânica específica (COE).

TABELA 5.1 - Variáveis monitoradas no ensaio do ASBR com biomassa imobilizada, operado em batelada de $8 \mathrm{~h}$ com alimentação de $500 \mathrm{mgDQO} / \mathrm{L}$.

\begin{tabular}{ccc}
\hline Variável & Afluente & Efluente \\
\hline $\mathrm{C}_{\mathrm{ET}}(\mathrm{mgDQO} / \mathrm{L})$ & $492 \pm 49(27)$ & $73 \pm 14(15)$ \\
$\mathrm{C}_{\mathrm{EF}}(\mathrm{mgDQO} / \mathrm{L})$ & - & $61 \pm 12(15)$ \\
$\varepsilon_{\mathrm{ET}}(\%)$ & - & $85 \pm 3(15)$ \\
$\varepsilon_{\mathrm{EF}}(\%)$ & - & $88 \pm 3(15)$ \\
$\mathrm{AB}\left(\mathrm{mgCaCO}_{3} / \mathrm{L}\right)$ & $126 \pm 7(15)$ & $233 \pm 7(6)$ \\
$\mathrm{AVT}(\mathrm{mgHAc} / \mathrm{L})$ & $30 \pm 5(15)$ & $19 \pm 1(6)$ \\
$\mathrm{pH}$ & $8,3 \pm 0,7(15)$ & $7,5 \pm 0,1(6)$ \\
$\mathrm{AI} / \mathrm{AP}$ & $0,26 \pm 0,06(15)$ & $0,21 \pm 0,03(6)$ \\
$\mathrm{ST}(\mathrm{mg} / \mathrm{L})$ & $1081 \pm 42(7)$ & $665 \pm 99(7)$ \\
$\mathrm{SVT}(\mathrm{mg} / \mathrm{L})$ & $636 \pm 50(7)$ & $263 \pm 72(7)$ \\
$\mathrm{SST}(\mathrm{mg} / \mathrm{L})$ & $54 \pm 16(7)$ & $33 \pm 11(7)$ \\
$\mathrm{SSV}(\mathrm{mg} / \mathrm{L})$ & $38 \pm 18(7)$ & $23 \pm 15(7)$ \\
$\mathrm{V}$ olume $(\mathrm{L})$ & - & $2,00 \pm 0,07(15)$
\end{tabular}

OBS: Os valores entre parênteses são referentes ao número de amostras utilizadas para cálculo da média e do desvio padrão. 
TABELA 5.2 - Parâmetros operacionais para a primeira condição operacional.

\begin{tabular}{|c|c|c|c|c|c|c|}
\hline $\begin{array}{c}\mathrm{C}_{\mathrm{ST}} \\
\text { (gST/g esp.) }\end{array}$ & $\begin{array}{c}\mathrm{C}_{\mathrm{SVT}} \\
\text { (gSVT/g esp.) }\end{array}$ & $\begin{array}{c}\gamma \\
\text { (g esp./g esp. Inoc.) }\end{array}$ & $\begin{array}{c}\mathrm{M}_{\mathrm{INOC}} \\
\text { (g esp. Inoc) }\end{array}$ & $\begin{array}{c}\mathrm{X} \\
\text { (gSVT) }\end{array}$ & (gDQC & $\begin{array}{l}\text { E } \\
\text { VT.dia) }\end{array}$ \\
\hline 1175 & 1005 & 0,03252 & 1343 & 44 & \multicolumn{2}{|c|}{0,067} \\
\hline $\begin{array}{c}\mathrm{C}_{\mathrm{A}} \\
(\mathrm{gDQO} / \mathrm{L})\end{array}$ & $\begin{array}{l}\mathrm{t}_{\mathrm{C}} \\
\text { (h) }\end{array}$ & $\begin{array}{l}\mathrm{V}_{\mathrm{ALI}} \\
(\mathrm{L})\end{array}$ & $\begin{array}{c}\mathrm{COV} \\
(\mathrm{gDQO} / \mathrm{L} \cdot \mathrm{dia})\end{array}$ & $\begin{array}{c}\mathrm{COV}_{\mathrm{IM}} \\
\text { (gDQO/L.dia) }\end{array}$ & $\begin{array}{l}\text { TDH } \\
\text { (dia) }\end{array}$ & $\begin{array}{c}\mathrm{TDH}_{\mathrm{IM}} \\
\text { (dia) }\end{array}$ \\
\hline 0,492 & 8 & 2,00 & 0,547 & 1,476 & 0,90 & 0,33 \\
\hline
\end{tabular}

Como a água residuária sintética é desprovida de sólidos particulados, os dados referentes às concentrações de sólidos apresentados na TABELA 5.1 são úteis para mostrar que o sistema não apresentou perda de sólidos para essa condição.

Na FIGURA 5.1 são apresentadas as curvas de concentração de substrato efluente, para amostras filtradas e não filtradas. Como pode ser observada, após o $26^{\circ}$ dia de operação, a DQO filtrada apresentou valor máximo de $79 \mathrm{mg} / \mathrm{L}$ e mínimo de 32 mg/L e a DQO não filtrada apresentou máximo de 97 mg/L e mínimo 47 mg/L.

A FIGURA 5.2 apresenta a eficiência de remoção de material orgânico, nas formas filtrada e não filtrada, desenvolvido pelo sistema. Os valores foram levantados com base na concentração média afluente. Para essa condição, foram observadas remoção máxima 94 \% e mínima de 84 \% para efluente filtrado, e remoção máxima de $90 \%$ e mínima de $80 \%$ para efluente não filtrado. 


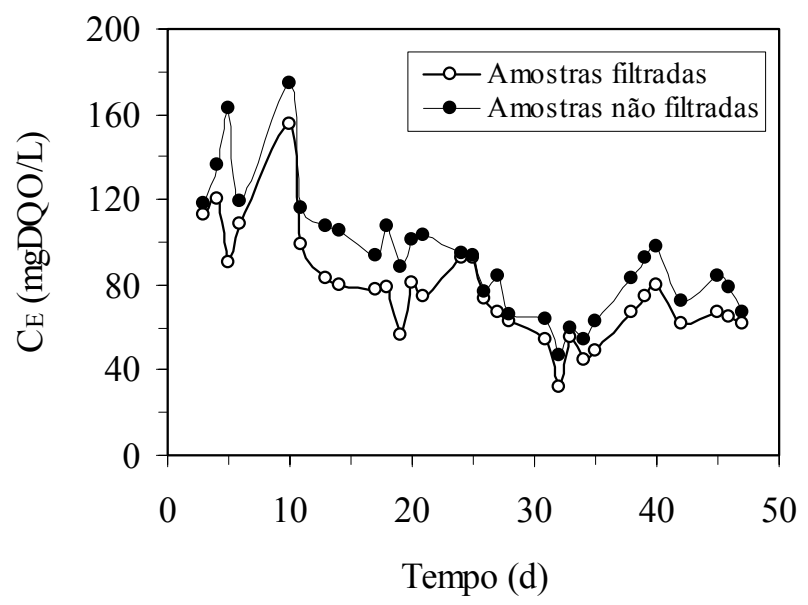

FIGURA 5.1 - Concentração de matéria orgânica efluente para amostras filtrada $\left(\mathrm{C}_{\mathrm{EF}}\right)$ e não filtrada $\left(\mathrm{C}_{\mathrm{ET}}\right)$, para condição de batelada de $8 \mathrm{~h}$ com alimentação de $500 \mathrm{mgDQO} / \mathrm{L}$.

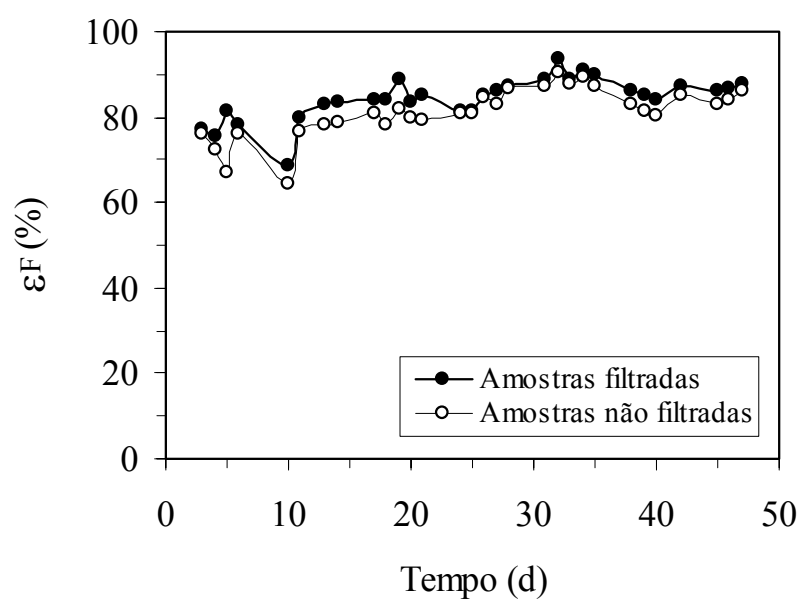

FIGURA 5.2 - Eficiência de remoção de material orgânico para amostras filtrada $\left(\varepsilon_{\mathrm{EF}}\right) \mathrm{e}$ não filtrada $\left(\varepsilon_{\mathrm{ET}}\right)$, para condição de batelada de $8 \mathrm{~h}$ com alimentação de $500 \mathrm{mgDQO} / \mathrm{L}$. 
A primeira condição foi aplicada com o objetivo de se fazerem os ajustes operacionais e estabelecimento de condições ótimas de remoção de matéria orgânica e liberação de subprodutos, como o biogás. Dessa forma, atentando para um possível excesso de espuma, foi retirado uma pequena parte dessa no $28^{\circ}$ dia, o que ocasionou um ganho significativo de eficiência de remoção de matéria orgânica.

A FIGURA 5.3 apresenta os valores da alcalinidade a bicarbonato para o efluente, comparado com a alcalinidade média afluente durante todo o período de ensaio. A FIGURA 5.4 apresenta a concentração de ácidos voláteis totais no efluente.

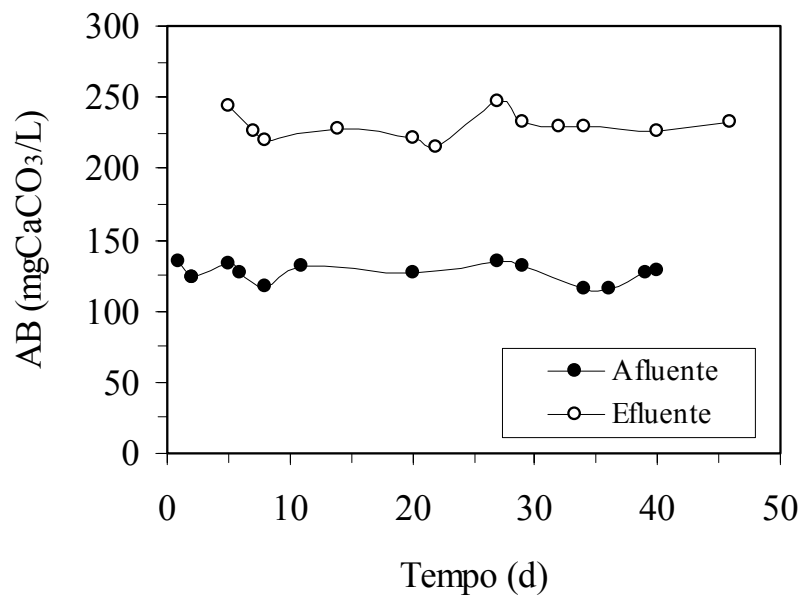

FIGURA 5.3 - Alcalinidade a bicarbonato (AB) efluente e afluente, para condição de batelada de $8 \mathrm{~h}$ com alimentação de $500 \mathrm{mgDQO} / \mathrm{L}$.

Com auxílio das figuras, pode-se perceber que houve produção de alcalinidade a bicarbonato e consumo dos ácidos voláteis produzidos durante todo o tempo para a primeira condição, o que representa uma operação estável durante todo o período. Essa 
estabilidade pode ser observada pelo valor do $\mathrm{pH}$, que se mantém numa faixa neutra, e pela relação $\mathrm{AI} / \mathrm{AP}$, que se manteve com valores abaixo de 0,3 .

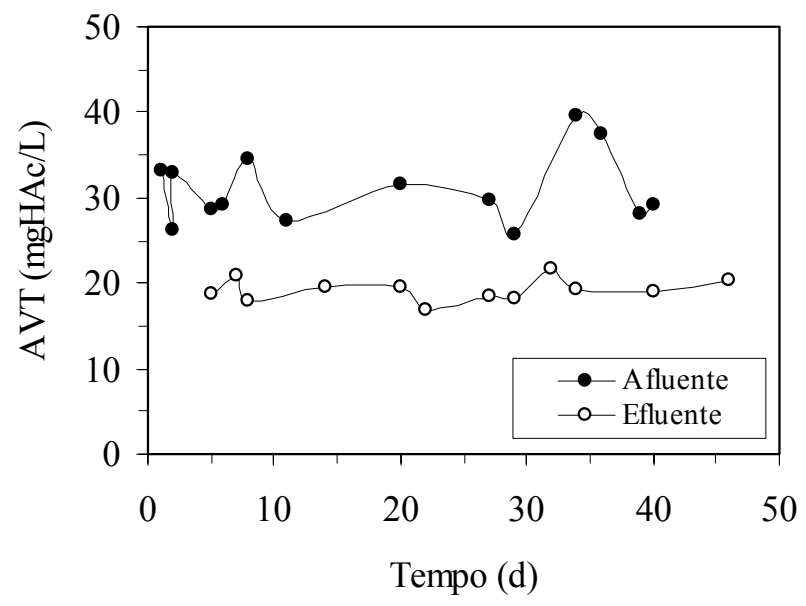

FIGURA 5.4 - Concentração de ácidos voláteis totais (AVT) efluente e afluente para condição de batelada de $8 \mathrm{~h}$ com alimentação de $500 \mathrm{mgDQO} / \mathrm{L}$.

\subsection{Concentração Afluente de $1000 \mathrm{mgDQO} / \mathrm{L}$ e ciclos de $8 \mathrm{~h}$}

Para a segunda condição, o reator foi monitorado durante um período superior a da primeira condição. Foram 67 dias de operação, nos quais o sistema só alcançou uma estabilidade nos valores efluentes monitorados ao fim do $34^{\circ}$ dia de operação. Desta forma, pode-se acompanhar o sistema operando há 33 dias sob condições estáveis.

Os valores originais para construção da tabelas e figuras, apresentadas nessa seção, encontram-se nas TABELAS II.3 e II.4 do APÊNDICE II, TABELAS III.3 e III.4 do APÊNDICE III e TABELAS IV.3, IV.4, IV.5 e IV.6 do APÊNDICE IV. 
A TABELA 5.3 resume os valores médios das variáveis monitoradas, lembrando que as médias afluentes são referentes a todos os valores obtidos, enquanto que as médias efluentes são referentes aos últimos 33 dias de operação. Os parâmetros operacionais foram calculados de acordo com as equações apresentadas no capítulo anterior e estão apresentadas na TABELA 5.4.

TABELA 5.3 - Variáveis monitoradas no ensaio do ASBR com biomassa imobilizada, operado em batelada de $8 \mathrm{~h}$ com alimentação de $1000 \mathrm{mgDQO} / \mathrm{L}$.

\begin{tabular}{ccc}
\hline Variável & Afluente & Efluente \\
\hline $\mathrm{C}_{\mathrm{ET}}(\mathrm{mgDQO} / \mathrm{L})$ & $962 \pm 84(37)$ & $315 \pm 71(19)$ \\
$\mathrm{C}_{\mathrm{EF}}(\mathrm{mgDQO} / \mathrm{L})$ & - & $264 \pm 59(19)$ \\
$\varepsilon_{\mathrm{ET}}(\%)$ & - & $67 \pm 7(19)$ \\
$\varepsilon_{\mathrm{EF}}(\%)$ & - & $73 \pm 6(19)$ \\
$\mathrm{AB}\left(\mathrm{mgCaCO}_{3} / \mathrm{L}\right)$ & $232 \pm 10(11)$ & $377 \pm 34(10)$ \\
$\mathrm{AVT}(\mathrm{mgHAc} / \mathrm{L})$ & $47 \pm 5(11)$ & $64 \pm 30(10)$ \\
$\mathrm{pH}$ & $8,2 \pm 0,7(11)$ & $7,0 \pm 0,1(10)$ \\
$\mathrm{AI} / \mathrm{AP}$ & $0,27 \pm 0,03(11)$ & $0,31 \pm 0,10(10)$ \\
$\mathrm{ST}(\mathrm{mg} / \mathrm{L})$ & $1714 \pm 347(11)$ & $1260 \pm 311(11)$ \\
$\mathrm{SVT}(\mathrm{mg} / \mathrm{L})$ & $947 \pm 262(11)$ & $450 \pm 204(11)$ \\
$\mathrm{SST}(\mathrm{mg} / \mathrm{L})$ & $54 \pm 15(11)$ & $52 \pm 23(11)$ \\
$\mathrm{SSV}(\mathrm{mg} / \mathrm{L})$ & $36 \pm 12(11)$ & $31 \pm 17(11)$ \\
$\mathrm{Volume}(\mathrm{L})$ & - & $1,99 \pm 0,05(17)$ \\
$\mathrm{CH}_{4}(\mathrm{mMol} / \mathrm{L})$ & - & $10,2 \pm 0,1(2)$ \\
$\mathrm{CO}_{2}(\mathrm{mMol} / \mathrm{L})$ & - & $5,1 \pm 0,0(2)$ \\
$\mathrm{CH}_{4}(\%)$ & - & $67 \pm 0(2)$ \\
$\mathrm{CO}_{2}(\%)$ & - & $33 \pm 0(2)$
\end{tabular}

OBS: Os valores entre parênteses são referentes ao número de amostras utilizadas para cálculo da média e do desvio padrão. 
TABELA 5.4 - Parâmetros operacionais para a segunda condição operacional.

\begin{tabular}{ccccccc}
\hline $\begin{array}{c}\mathrm{C}_{\mathrm{ST}} \\
(\mathrm{gST} / \mathrm{g} \text { esp. })\end{array}$ & $\begin{array}{c}\mathrm{C}_{\mathrm{SVT}} \\
(\mathrm{gSVT} / \mathrm{g} \text { esp. })\end{array}$ & $\begin{array}{c}\gamma \\
(\mathrm{g} \text { esp./g esp. Inoc. })\end{array}$ & $\begin{array}{c}\mathrm{M}_{\mathrm{INOC}} \\
(\mathrm{g} \text { esp. Inoc })\end{array}$ & $\begin{array}{c}\mathrm{X} \\
(\mathrm{gSVT})\end{array}$ & $\begin{array}{c}\mathrm{COE} \\
(\mathrm{gDQO} / \mathrm{gSVT} . d i a)\end{array}$ \\
\hline 1175 & 1005 & 0,03252 & 1343 & 44 & \multicolumn{2}{c}{0,131} \\
\hline $\mathrm{C}_{\mathrm{A}}$ & $\mathrm{t}_{\mathrm{C}}$ & $\mathrm{V}_{\mathrm{ALI}}$ & $\mathrm{COV}$ & $\mathrm{COV}_{\mathrm{IM}}$ & $\mathrm{TDH}$ & $\mathrm{TDH}_{\mathrm{IM}}$ \\
$(\mathrm{gDQO} / \mathrm{L})$ & $(\mathrm{h})$ & $(\mathrm{L})$ & $(\mathrm{gDQO} / \mathrm{L}$. dia $)$ & $(\mathrm{gDQO} / \mathrm{L}$. dia $)$ & $($ dia $)$ & $($ dia $)$ \\
\hline 0,962 & 8 & 1,99 & 1,064 & 2,886 & 0,90 & 0,33 \\
\hline
\end{tabular}

A TABELA 5.3 mostra que o sistema foi eficiente na retenção de sólidos dentro do reator, uma vez que a água residuária sintética era desprovida de material particulado.

Na FIGURA 5.5 são apresentadas as curvas de concentração de substrato efluente para amostras filtradas e não filtradas. Como pode ser observado, após o $34^{\circ}$ dia de operação, a DQO filtrada apresentou valor máximo de 365 mg/L e mínimo de 177 mg/L e a DQO não filtrada apresentou máximo de 416 mg/L e mínimo 195 mg/L.

Na FIGURA 5.6 são apresentados os valores de eficiência de remoção de material orgânico desenvolvido pelo sistema. Os valores foram calculados com base na concentração média de substrato afluente, obtendo-se o valor máximo de 82 \% e mínimo de $62 \%$ de eficiência, para efluente filtrado, e máximo de $80 \%$ e mínimo de $57 \%$ de eficiência para efluente não filtrado. 


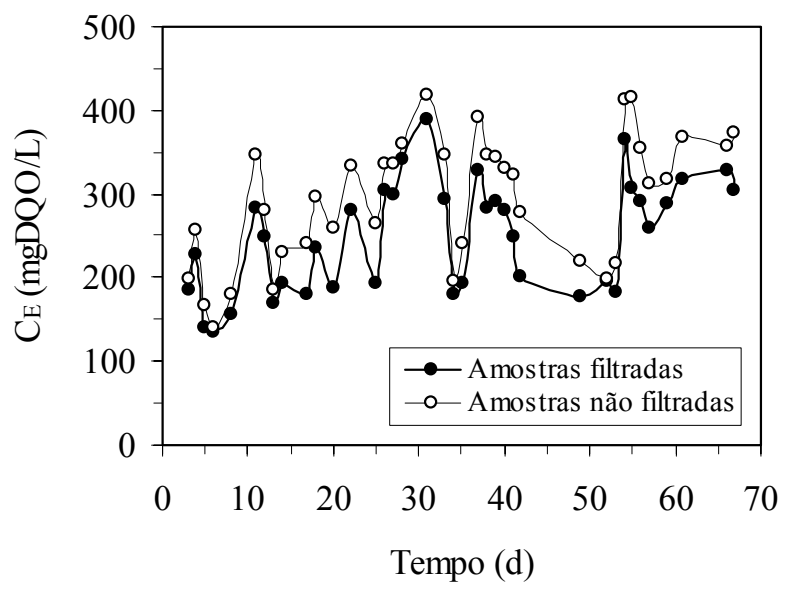

FIGURA 5.5 - Concentração de matéria orgânica efluente para amostras filtradas $\left(C_{E F}\right)$ e não filtradas $\left(\mathrm{C}_{\mathrm{ET}}\right)$, para condição de batelada de $8 \mathrm{~h}$ com alimentação de $1000 \mathrm{mgDQO} / \mathrm{L}$.

Na FIGURA 5.7 são apresentados os valores de alcalinidade a bicarbonato efluente e a FIGURA 5.8 mostra a concentração de ácidos voláteis totais efluentes, ambas para a segunda condição operacional e comparado com os valores afluentes.

Como pode ser observado nas figuras, a segunda condição operacional apresentou-se bem problemática, uma vez que grande concentração de polímero extracelular acumulava-se no cesto metálico, dificultando o contado do substrato com a biomassa. Assim, foi necessária a remoção do excesso de material gelatinoso. Desta forma, os valores da concentração de matéria orgânica efluente e concentração de ácidos voláteis totais apresentaram grandes variações para este estágio operacional, ocasionando grandes desvios padrões para a eficiência de remoção de matéria orgânica e produção de ácidos voláteis. Mesmo com todos estes desvios, a estabilidade operacional 
foi mantida, como pode ser observado pelos valores efluentes do $\mathrm{pH}$, mantidos sempre numa faixa neutra. Isso se deve, principalmente, à produção de alcalinidade a bicarbonato.

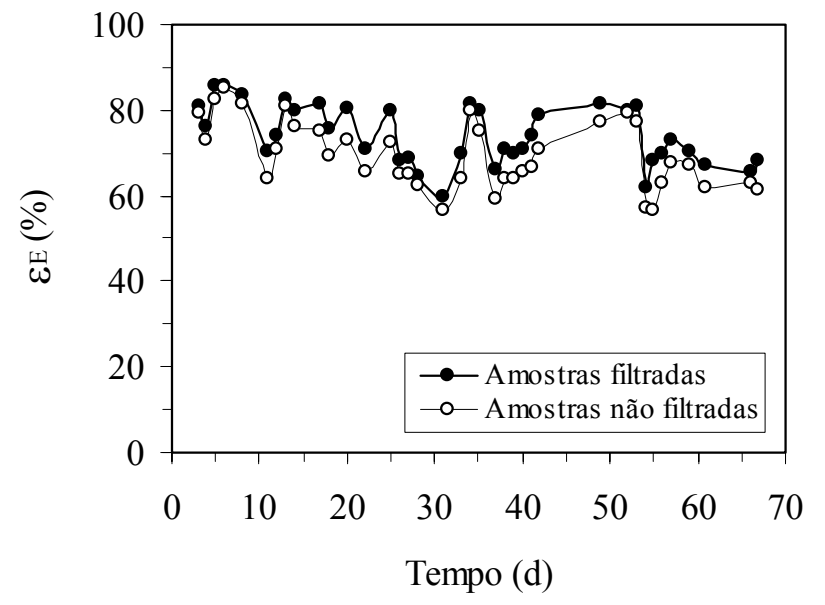

FIGURA 5.6 - Eficiência de remoção de material orgânico para amostras filtradas $\left(\varepsilon_{\mathrm{EF}}\right) \mathrm{e}$ não filtradas $\left(\varepsilon_{\mathrm{ET}}\right)$, para condição de batelada de $8 \mathrm{~h}$ com alimentação de $1000 \mathrm{mgDQO} / \mathrm{L}$. 


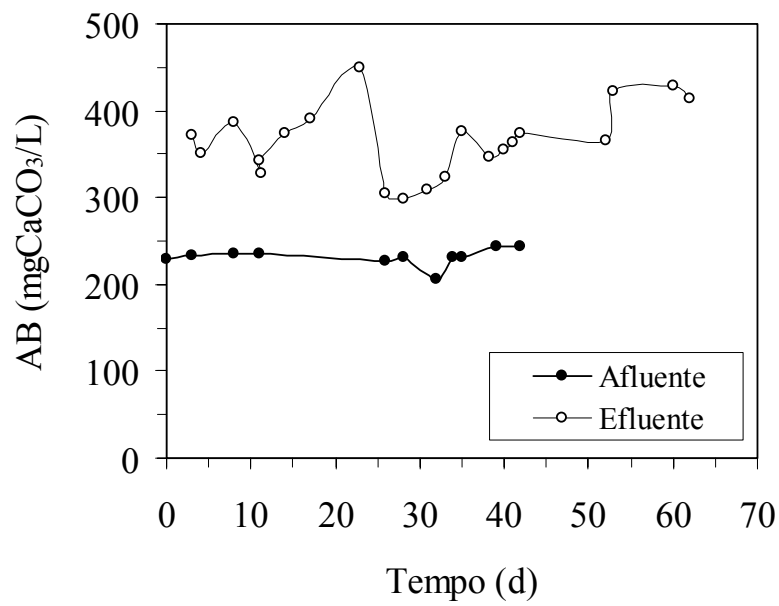

FIGURA 5.7 - Alcalinidade a bicarbonato (AB) efluente e afluente, para condição de batelada de $8 \mathrm{~h}$ com alimentação de $1000 \mathrm{mgDQO} / \mathrm{L}$.

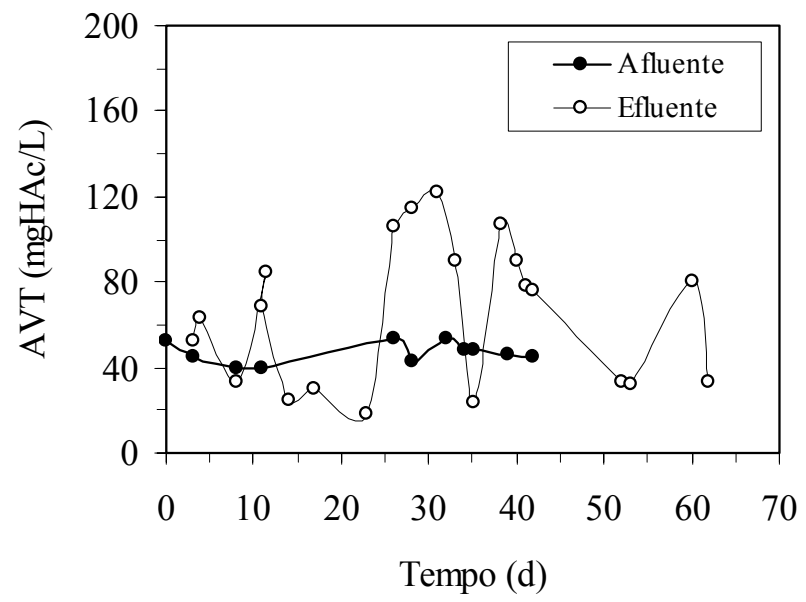

FIGURA 5.8 - Concentração de ácidos voláteis totais (AVT) efluente e afluente, para condição de batelada de $8 \mathrm{~h}$ com alimentação de1000 mgDQO/L. 


\subsection{Concentração Afluente de $2000 \mathrm{mgDQO} / \mathrm{L}$ e ciclos de $8 \mathrm{~h}$}

Na terceira condição de operação, a eficiência de remoção de material orgânico caiu drasticamente. Após o vigésimo dia de operação o sistema já demonstrava eficiência máxima de conversão. Desta forma, optou-se por levantar os perfis na condição atual com apenas 20 dias de operação.

Os valores originais para construção da tabelas e figuras apresentadas nessa seção encontram-se nas TABELAS II.5 e II.6 do APÊNDICE II, TABELAS III.5 e III.6 do APÊNDICE III e TABELAS IV.7, IV.8, IV.9 e IV.10 do APÊNDICE IV.

A TABELA 5.5 resume os valores médios das variáveis monitoradas, lembrando que as médias afluentes e efluentes são referentes a todos os valores obtidos para os 20 dias de operação. A TABELA 5.6 apresenta os valores dos parâmetros operacionais calculados para essa condição experimental, conforme equacionamento proposto anteriormente.

Na FIGURA 5.9 são apresentados os valores da concentração de substrato efluente para amostras filtradas e não filtradas. Para a terceira etapa, a DQO filtrada apresentou valor máximo de $940 \mathrm{mg} / \mathrm{L}$ e mínimo de $565 \mathrm{mg} / \mathrm{L}$ e a DQO não filtrada apresentou máximo de 980 mg/L e mínimo 598 mg/L.

A FIGURA 5.10 apresenta a eficiência de remoção de matéria orgânica desenvolvido pelo sistema e foi feita com base na concentração média de substrato afluente, obtendo-se máximo de $69 \%$ e mínimo de $48 \%$ de eficiência para efluente filtrado e máximo de $67 \%$ e mínimo de $46 \%$ de eficiência para efluente não filtrado. 
TABELA 5.5 - Variáveis monitoradas no ensaio do ASBR com biomassa imobilizada, operado em batelada de $8 \mathrm{~h}$ com alimentação de $2000 \mathrm{mgDQO} / \mathrm{L}$.

\begin{tabular}{ccc}
\hline Variável & Afluente & Efluente \\
\hline $\mathrm{C}_{\mathrm{ET}}(\mathrm{mgDQO} / \mathrm{L})$ & $1811 \pm 146(11)$ & $844 \pm 97(15)$ \\
$\mathrm{C}_{\mathrm{EF}}(\mathrm{mgDQO} / \mathrm{L})$ & - & $810 \pm 98(15)$ \\
$\varepsilon_{\mathrm{ET}}(\%)$ & - & $53 \pm 5(15)$ \\
$\varepsilon_{\mathrm{EF}}(\%)$ & - & $55 \pm 5(15)$ \\
$\mathrm{AB}(\mathrm{mgCaCO} / \mathrm{L})$ & $511 \pm 11(7)$ & $459 \pm 42(11)$ \\
$\mathrm{AVT}(\mathrm{mgHAc} / \mathrm{L})$ & $84 \pm 7(7)$ & $430 \pm 99(11)$ \\
$\mathrm{pH}$ & $8,5 \pm 0,3(7)$ & $6,8 \pm 0,1(11)$ \\
$\mathrm{AI} / \mathrm{AP}$ & $0,27 \pm 0,01(7)$ & $0,69 \pm 0,12(11)$ \\
$\mathrm{ST}(\mathrm{mg} / \mathrm{L})$ & $3196 \pm 192(5)$ & $235 \pm 150(5)$ \\
$\mathrm{SVT}(\mathrm{mg} / \mathrm{L})$ & $1485 \pm 54(5)$ & $656 \pm 86(5)$ \\
$\mathrm{SST}(\mathrm{mg} / \mathrm{L})$ & $70 \pm 25(5)$ & $71 \pm 20(5)$ \\
$\mathrm{SSV}(\mathrm{mg} / \mathrm{L})$ & $46 \pm 21(5)$ & $58 \pm 23(5)$ \\
$\mathrm{Volume}(\mathrm{L})$ & - & $2,03 \pm 0,04(15)$ \\
$\mathrm{CH}_{4}(\mathrm{mMol} / \mathrm{L})$ & - & $8,5 \pm 0,0(1)$ \\
$\mathrm{CO}_{2}(\mathrm{mMol} / \mathrm{L})$ & - & $6,7 \pm 0,0(1)$ \\
$\mathrm{CH}_{4}(\%)$ & - & $56 \pm 0(1)$ \\
$\mathrm{CO}_{2}(\%)$ & - & $44 \pm 0(1)$ \\
\hline
\end{tabular}

OBS: O valor entre parênteses é referente ao número de amostras utilizadas para cálculo da média e do desvio padrão.

Na FIGURA 5.11, são apresentados os valores de alcalinidade a bicarbonato efluente, comparado com os valores afluentes e a FIGURA 5.12 mostra a concentração de ácidos orgânicos voláteis totais para o sistema ASBR com biomassa imobilizada. 
TABELA 5.6 - Parâmetros operacionais para a terceira condição operacional.

\begin{tabular}{|c|c|c|c|c|c|c|}
\hline $\begin{array}{c}\mathrm{C}_{\mathrm{ST}} \\
\text { (gST/g esp.) }\end{array}$ & $\begin{array}{c}\mathrm{C}_{\mathrm{SVT}} \\
\text { (gSVT/g esp.) }\end{array}$ & $\begin{array}{c}\gamma \\
\text { (g esp./g esp. Inoc.) }\end{array}$ & $\begin{array}{c}\mathrm{M}_{\mathrm{INOC}} \\
\text { (g esp. Inoc) }\end{array}$ & $\begin{array}{c}\mathrm{X} \\
(\mathrm{gSVT})\end{array}$ & (gDQ & $\begin{array}{l}\text { E } \\
\text { VT.dia) }\end{array}$ \\
\hline 1139 & 1124 & 0,02468 & 1763 & 49 & \multicolumn{2}{|c|}{0,226} \\
\hline $\mathrm{C}_{\mathrm{A}}$ & $t_{C}$ & $\mathrm{~V}_{\mathrm{ALI}}$ & $\mathrm{COV}$ & $\mathrm{COV}_{\mathrm{IM}}$ & TDH & $\mathrm{TDH}_{\mathrm{IM}}$ \\
\hline$(\mathrm{gDQO} / \mathrm{L})$ & (h) & (L) & (gDQO/L.dia) & (gDQO/L.dia) & (dia) & (dia) \\
\hline 1,811 & 8 & 2,03 & 2,042 & 5,433 & 0,90 & 0,33 \\
\hline
\end{tabular}

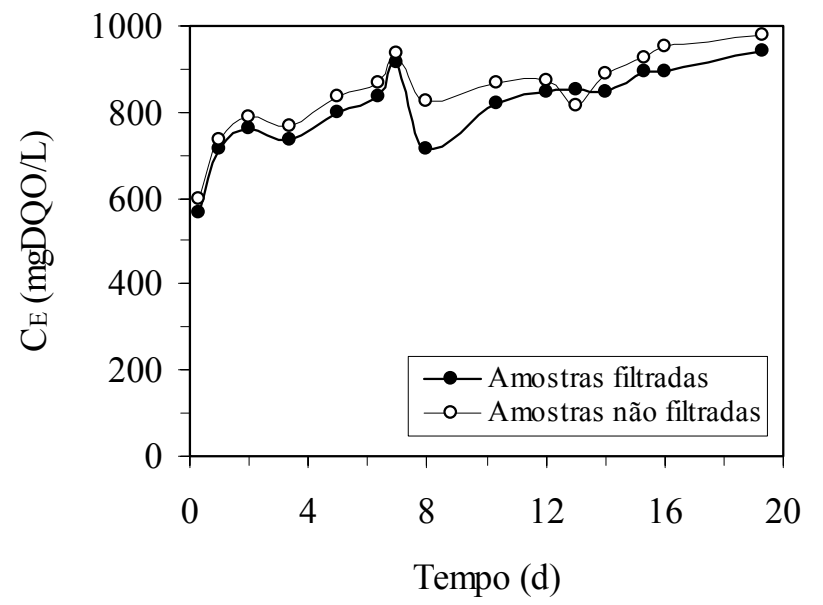

FIGURA 5.9 - Concentração de matéria orgânica efluente para amostras filtrada $\left(\mathrm{C}_{\mathrm{EF}}\right)$ e não filtrada $\left(\mathrm{C}_{\mathrm{ET}}\right)$, para batelada de $8 \mathrm{~h}$ com alimentação de $2000 \mathrm{mgDQO} / \mathrm{L}$. 


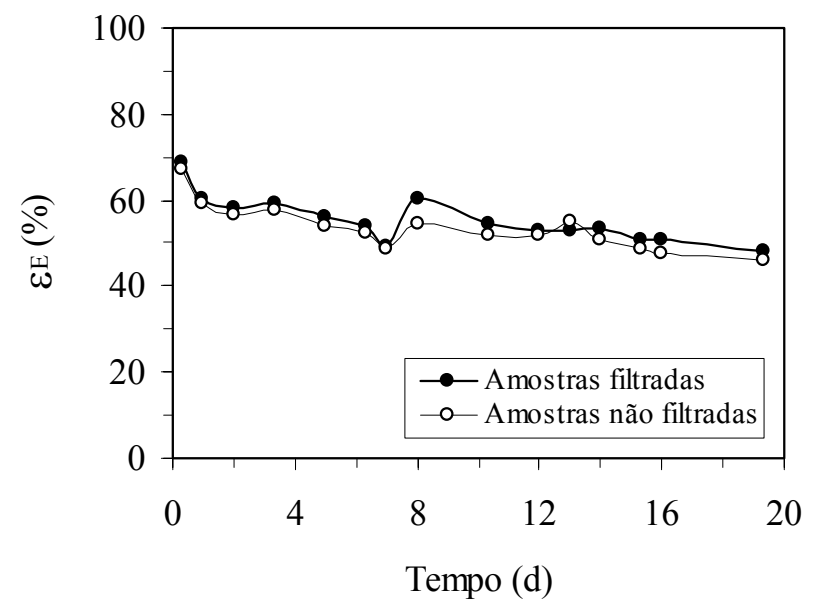

Figura 5.10 - Eficiência de remoção de material orgânico para amostras filtrada $\left(\varepsilon_{\mathrm{EF}}\right)$ e não filtrada $\left(\varepsilon_{\mathrm{ET}}\right)$, para batelada de $8 \mathrm{~h}$ com alimentação de $2000 \mathrm{mgDQO} / \mathrm{L}$.

Essa condição apresentou-se como limite para o carregamento orgânico volumétrico. Com bateladas de 8 horas, o reator atingiu baixíssimas eficiências de remoção de material orgânico. Encontra-se no acúmulo de ácidos voláteis a razão para o consumo de solução tamponante, representada pela concentração de alcalinidade a bicarbonato e, possivelmente, o aumento na DQO efluente para esta etapa operacional. Mesmo havendo o consumo de alcalinidade a bicarbonato, o valor afluente foi suficiente para garantir o tamponamento do meio reacional e garantir a estabilidade operacional. 


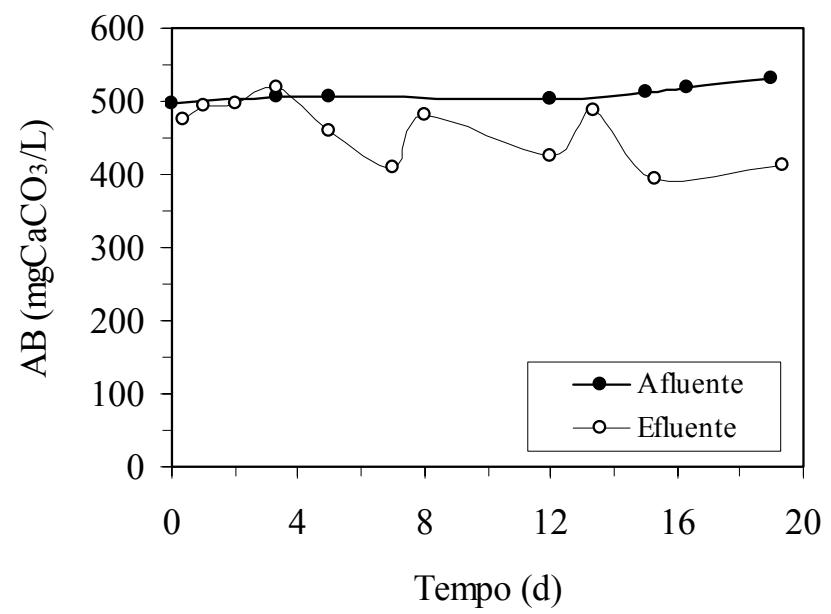

FIGURA 5.11 - Alcalinidade a bicarbonato (AB) efluente e afluente, para batelada de 8 h com alimentação de 2000 mgDQO/L.

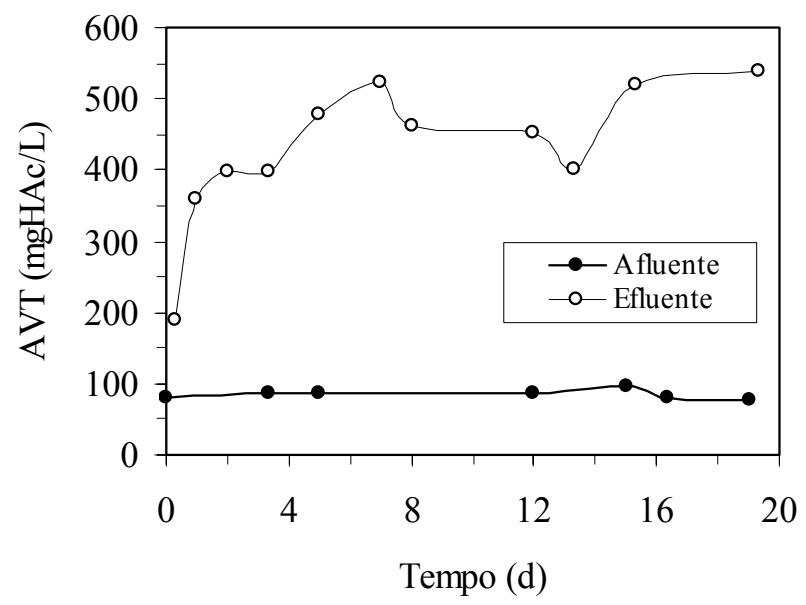

FIGURA 5.12 - Concentração de ácidos voláteis totais (AVT) efluente e afluente, para batelada de $8 \mathrm{~h}$ com alimentação de $2000 \mathrm{mgDQO} / \mathrm{L}$. 


\subsection{Concentração Afluente de $2000 \mathrm{mgDQO} / \mathrm{L}$ e ciclos de $12 \mathrm{~h}$}

$\mathrm{Na}$ quarta condição de trabalho, operada com um tempo de ciclo de $12 \mathrm{~h}$, o reator foi monitorado durante um período de 35 dias, sendo verificada estabilidade nas variáveis monitoradas após o $25^{\circ}$ dia de operação. Desta forma, pode-se acompanhar o sistema operando há 10 dias sob condições estáveis.

Os valores originais para construção da tabelas e figuras apresentadas nessa seção encontram-se nas TABELAS II.7 e II.8 do APÊNDICE II, TABELAS III.7 e III.8 do APÊNDICE III e TABELAS IV.11, IV.12, IV.13 e IV.14 do APÊNDICE IV.

A TABELA 5.7 resume os valores médios das variáveis monitoradas, lembrando que as médias afluentes são referentes a todos os valores obtidos, enquanto que as médias efluentes são referentes aos últimos 10 dias de operação. A TABELA 5.8 apresenta os valores dos parâmetros operacionais calculados para essa condição experimental, conforme equacionamento proposto anteriormente.

Na FIGURA 5.13 são apresentadas as curvas de concentração de substrato efluente, para amostras filtradas e não filtradas. Após o $25^{\circ}$ dia de operação, a DQO filtrada apresentou valor máximo de $377 \mathrm{mg} / \mathrm{L}$ e mínimo de $323 \mathrm{mg} / \mathrm{L}$ e a DQO não filtrada apresentou valor máximo de $423 \mathrm{mg} / \mathrm{L}$ e mínimo $352 \mathrm{mg} / \mathrm{L}$.

A FIGURA 5.14 apresenta a eficiência média de remoção de material orgânico desenvolvida pelo sistema e foi calculada com base na concentração média do afluente, obtendo-se máximo de $82 \%$ e mínimo de $79 \%$ de eficiência para efluente filtrado e máximo de $81 \%$ e mínimo de $77 \%$ de eficiência para efluente não filtrado. 
TABELA 5.7 - Variáveis monitoradas no ensaio do ASBR com biomassa imobilizada, operado em batelada de $12 \mathrm{~h}$ com alimentação de $2000 \mathrm{mgDQO} / \mathrm{L}$.

\begin{tabular}{ccc}
\hline Variável & Afluente & Efluente \\
\hline $\mathrm{C}_{\mathrm{ET}}(\mathrm{mgDQO} / \mathrm{L})$ & $1808 \pm 108(15)$ & $385 \pm 25(7)$ \\
$\mathrm{C}_{\mathrm{EF}}(\mathrm{mgDQO} / \mathrm{L})$ & - & $352 \pm 21(7)$ \\
$\varepsilon_{\mathrm{ET}}(\%)$ & - & $79 \pm 1(7)$ \\
$\varepsilon_{\mathrm{EF}}(\%)$ & - & $81 \pm 1(7)$ \\
$\mathrm{AB}(\mathrm{mgCaCO} / \mathrm{L})$ & $466 \pm 11(7)$ & $799 \pm 34(4)$ \\
$\mathrm{AVT}(\mathrm{mgHAc} / \mathrm{L})$ & $75 \pm 9(7)$ & $96 \pm 12(4)$ \\
$\mathrm{pH}$ & $8,8 \pm 0,1(7)$ & $7,3 \pm 0,3(4)$ \\
$\mathrm{AI} / \mathrm{AP}$ & $0,28 \pm 0,02(7)$ & $0,33 \pm 0,02(4)$ \\
$\mathrm{ST}(\mathrm{mg} / \mathrm{L})$ & $3232 \pm 131(7)$ & $2271 \pm 120(7)$ \\
$\mathrm{SVT}(\mathrm{mg} / \mathrm{L})$ & $1434 \pm 139(7)$ & $493 \pm 104(7)$ \\
$\mathrm{SST}(\mathrm{mg} / \mathrm{L})$ & $106 \pm 37(6)$ & $65 \pm 17(7)$ \\
$\mathrm{SSV}(\mathrm{mg} / \mathrm{L})$ & $65 \pm 21(6)$ & $29 \pm 10(7)$ \\
$\mathrm{Volume}(\mathrm{L})$ & - & $2,01 \pm 0,05(15)$ \\
$\mathrm{CH}_{4}(\mathrm{mMol} / \mathrm{L})$ & - & $14,9 \pm 0,4(2)$ \\
$\mathrm{CO}_{2}(\mathrm{mMol} / \mathrm{L})$ & - & $6,1 \pm 0,0(2)$ \\
$\mathrm{CH}_{4}(\%)$ & - & $71 \pm 0(2)$ \\
$\mathrm{CO}_{2}(\%)$ & - & $29 \pm 0(2)$ \\
\hline $0 \mathrm{O} \%$ & - &
\end{tabular}

OBS: O valor entre parênteses é referente ao número de amostras utilizadas para cálculo da média e do desvio padrão.

Na FIGURA 5.15 são apresentados os valores de alcalinidade a bicarbonato efluente, comparado com os valores afluentes. A FIGURA 5.16 mostra a concentração de ácidos orgânicos voláteis totais. 
TABELA 5.8 - Parâmetros operacionais para a quarta condição operacional.

\begin{tabular}{ccccccc}
\hline $\begin{array}{c}\mathrm{C}_{\mathrm{ST}} \\
(\mathrm{gST} / \mathrm{g} \text { esp. })\end{array}$ & $\begin{array}{c}\mathrm{C}_{\mathrm{SVT}} \\
(\mathrm{gSVT} / \mathrm{g} \text { esp. })\end{array}$ & $\begin{array}{c}\gamma \\
\text { (g esp./g esp. Inoc. })\end{array}$ & $\begin{array}{c}\mathrm{M}_{\mathrm{INOC}} \\
(\mathrm{g} \text { esp. Inoc) }\end{array}$ & $\begin{array}{c}\mathrm{X} \\
(\mathrm{gSVT})\end{array}$ & $\begin{array}{c}\mathrm{COE} \\
\text { (gDQO/gSVT.dia) }\end{array}$ \\
\hline 1460 & 1276 & 0,02864 & 1515 & 55 & 0,131 \\
\hline $\mathrm{C}_{\mathrm{A}}$ & $\mathrm{t}_{\mathrm{C}}$ & $\mathrm{V}_{\mathrm{ALI}}$ & $\mathrm{COV}$ & $\mathrm{COV}_{\mathrm{IM}}$ & $\mathrm{TDH}$ & $\mathrm{TDH}_{\mathrm{IM}}$ \\
$(\mathrm{gDQO} / \mathrm{L})$ & $(\mathrm{h})$ & $(\mathrm{L})$ & $(\mathrm{gDQO} / \mathrm{L}$. dia $)$ & $(\mathrm{gDQO} / \mathrm{L}$.dia) & $($ dia $)$ & $($ dia $)$ \\
\hline 1,808 & 12 & 2,01 & 1,346 & 3,616 & 1,34 & 0,50 \\
\hline
\end{tabular}

Com base nas figuras e no valor da concentração de metano apresentada na TABELA 5.7, pode-se observar que na quarta condição operacional, com uma concentração afluente igual anterior, porém com um tempo de batelada de 12 horas, as 4 horas dadas a mais para o ciclo foram suficientes para que os microrganismos consumissem, quase que totalmente, os de ácidos voláteis totais produzidos.

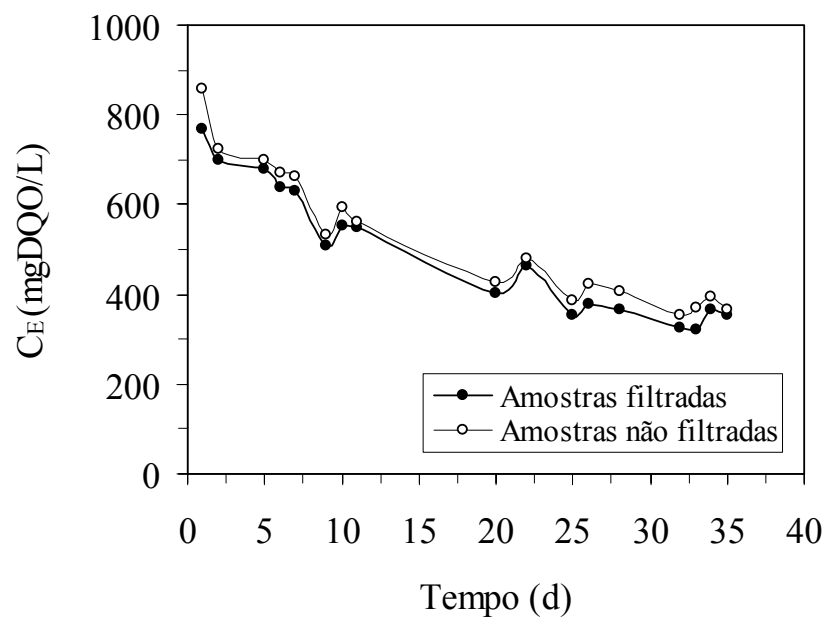

FIGURA 5.13 - Concentração de matéria orgânica efluente para amostras filtrada $\left(\mathrm{C}_{\mathrm{EF}}\right) \mathrm{e}$ não filtrada $\left(\mathrm{C}_{\mathrm{ET}}\right)$, para batelada de $12 \mathrm{~h}$ com alimentação de $2000 \mathrm{mgDQO} / \mathrm{L}$. 


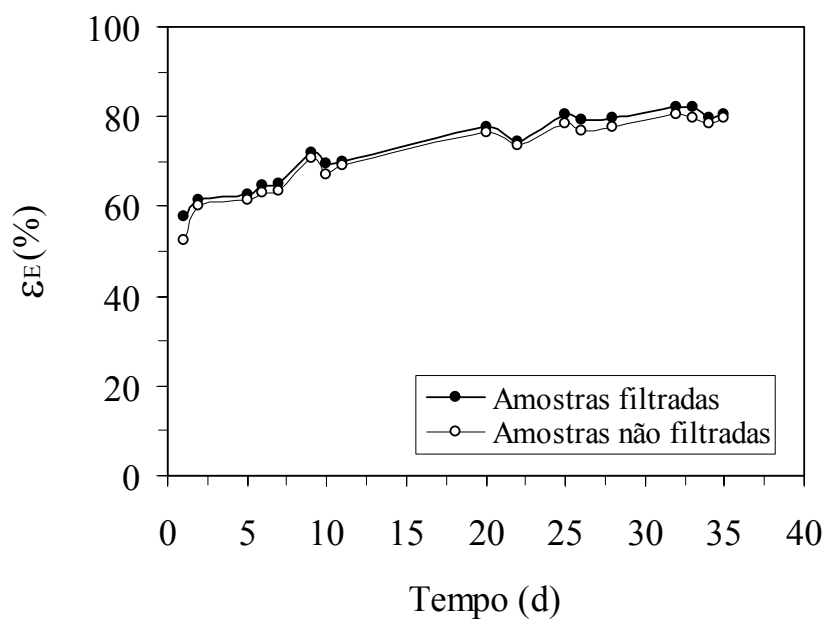

FIGURA 5.14 - Eficiência de remoção de material orgânico para amostras filtrada $\left(\varepsilon_{\mathrm{EF}}\right)$ e não filtrada $\left(\varepsilon_{\mathrm{ET}}\right)$, para batelada de $12 \mathrm{~h}$ com alimentação de $2000 \mathrm{mgDQO} / \mathrm{L}$.

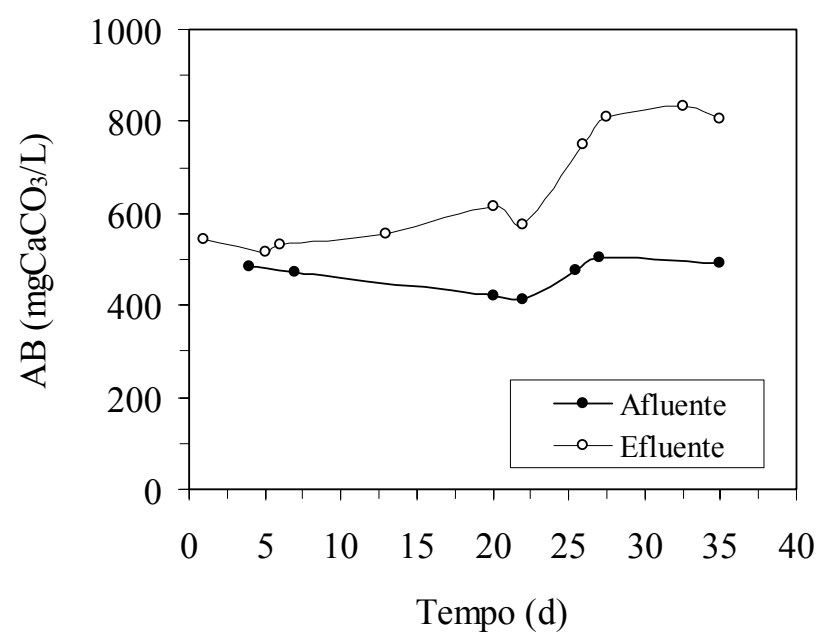

FIGURA 5.15 - Alcalinidade a bicarbonato (AB) efluente e afluente, para batelada de 12 h com alimentação 2000 mgDQO/L. 


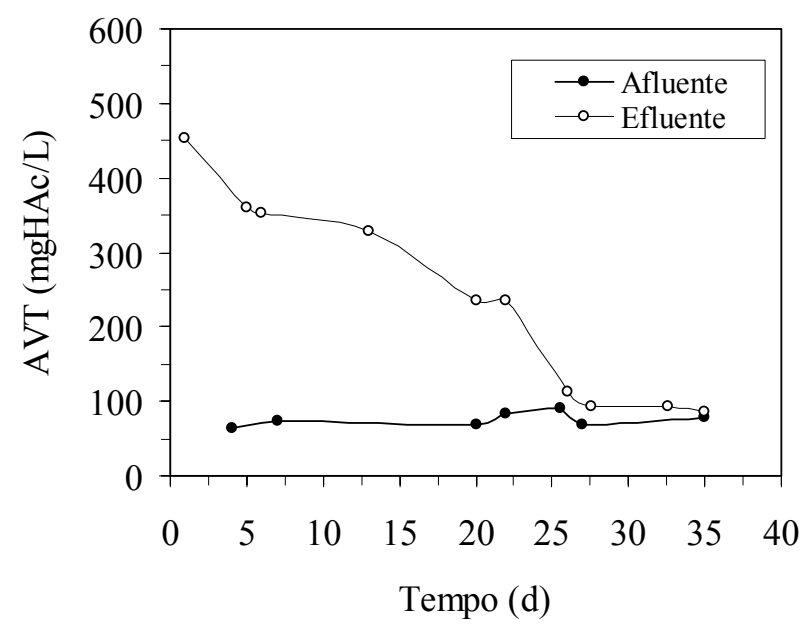

FIGURA 5.16 - Concentração de ácidos voláteis totais (AVT) efluente e afluente, para batelada de 12 h com alimentação de 2000 mgDQO/L.

\subsection{Concentração Afluente de $1500 \mathrm{mgDQO} / \mathrm{L}$ e ciclos de $12 \mathrm{~h}$}

$\mathrm{Na}$ quinta condição de trabalho, com um tempo de ciclo de $12 \mathrm{~h}$, o reator foi operado durante um período de 31 dias, sendo verificada estabilidade nos valores monitorados após o $7^{\circ}$ dia de operação. Desta forma, pode-se acompanhar o sistema operando há 24 dias sob condições estáveis.

Os valores originais para construção da tabelas e figuras apresentadas nessa seção encontram-se nas TABELAS II.9 e II.10 do APÊNDICE II, TABELAS III.9 e III.10 do APÊNDICE III e TABELAS IV.15, IV.16, IV.17 e IV.18 do APÊNDICE IV.

A TABELA 5.9 resume os valores médios das variáveis monitoradas, lembrando que as médias afluentes são referentes a todos os valores obtidos, enquanto que as médias efluentes são referentes aos últimos 24 dias de operação. A TABELA 5.10 
apresenta os valores dos parâmetros operacionais calculados para essa condição experimental, conforme equacionamento proposto anteriormente.

TABELA 5.9 - Variáveis monitoradas no ensaio do ASBR com biomassa imobilizada, operado com batelada de $12 \mathrm{~h}$ com alimentação de 1500 mgDQO/L.

\begin{tabular}{ccc}
\hline Variável & Afluente & Efluente \\
\hline $\mathrm{C}_{\mathrm{ET}}(\mathrm{mgDQO} / \mathrm{L})$ & $1389 \pm 111(19)$ & $266 \pm 22(14)$ \\
$\mathrm{C}_{\mathrm{EF}}(\mathrm{mgDQO} / \mathrm{L})$ & - & $243 \pm 19(14)$ \\
$\varepsilon_{\mathrm{ET}}(\%)$ & - & $81 \pm 2(14)$ \\
$\varepsilon_{\mathrm{EF}}(\%)$ & - & $83 \pm 1(14)$ \\
$\mathrm{AB}(\mathrm{mgCaCO} / \mathrm{L})$ & $376 \pm 22(11)$ & $623 \pm 32(10)$ \\
$\mathrm{AVT}(\mathrm{mgHAc} / \mathrm{L})$ & $68 \pm 9(11)$ & $73 \pm 6(10)$ \\
$\mathrm{pH}$ & $8,8 \pm 0,2(11)$ & $7,0 \pm 0,1(10)$ \\
$\mathrm{AI} / \mathrm{AP}$ & $0,25 \pm 0,03(11)$ & $0,32 \pm 0,04(10)$ \\
$\mathrm{ST}(\mathrm{mg} / \mathrm{L})$ & $2435 \pm 144(5)$ & $1602 \pm 279(4)$ \\
$\mathrm{SVT}(\mathrm{mg} / \mathrm{L})$ & $1148 \pm 89(5)$ & $340 \pm 63(4)$ \\
$\mathrm{SST}(\mathrm{mg} / \mathrm{L})$ & $136 \pm 82(5)$ & $54 \pm 16(4)$ \\
$\mathrm{SSV}(\mathrm{mg} / \mathrm{L})$ & $72 \pm 46(5)$ & $27 \pm 5(4)$ \\
$\mathrm{Volume}(\mathrm{L})$ & - & $2,01 \pm 0,04(12)$ \\
$\mathrm{CH}_{4}(\mathrm{mMol} / \mathrm{L})$ & - & $13,5 \pm 0,0(1)$ \\
$\mathrm{CO}_{2}(\mathrm{mMol} / \mathrm{L})$ & - & $5,5 \pm 0,0(1)$ \\
$\mathrm{CH}_{4}(\%)$ & - & $71 \pm 0(1)$ \\
$\mathrm{CO}_{2}(\%)$ & - & $29 \pm 0(1)$ \\
\hline
\end{tabular}

OBS: O valor entre parênteses é referente ao número de amostras utilizadas para cálculo da média e do desvio padrão.

Na FIGURA 5.17 são apresentados os valores da concentração de substrato efluente para amostras filtradas e não filtradas. Após o $7^{\circ}$ dia de operação, a DQO 
filtrada apresentou valor máximo de $271 \mathrm{mg} / \mathrm{L}$ e mínimo de $203 \mathrm{mg} / \mathrm{L}$ e a DQO não filtrada apresentou valor máximo de $301 \mathrm{mg} / \mathrm{L}$ e mínimo $225 \mathrm{mg} / \mathrm{L}$.

TABELA 5.10- Parâmetros operacionais calculados para a quinta condição operacional.

\begin{tabular}{ccccccc}
\hline $\begin{array}{c}\mathrm{C}_{\mathrm{ST}} \\
(\mathrm{gST} / \mathrm{g} \text { esp. })\end{array}$ & $\begin{array}{c}\mathrm{C}_{\mathrm{SVT}} \\
(\mathrm{gSVT} / \mathrm{g} \text { esp. })\end{array}$ & $\begin{array}{c}\gamma \\
(\mathrm{g} \text { esp./g esp. Inoc. })\end{array}$ & $\begin{array}{c}\mathrm{M}_{\mathrm{INOC}} \\
(\mathrm{g} \text { esp. Inoc })\end{array}$ & $\begin{array}{c}\mathrm{X} \\
(\mathrm{gSVT})\end{array}$ & $\begin{array}{c}\mathrm{COE} \\
(\mathrm{gDQO} / \mathrm{gSVT} \text {.dia })\end{array}$ \\
\hline 1515 & 1332 & 0,02521 & 1846 & 62 & 0,090 \\
\hline $\mathrm{C}_{\mathrm{A}}$ & $\mathrm{t}_{\mathrm{C}}$ & $\mathrm{V}_{\mathrm{ALI}}$ & $\mathrm{COV}$ & $\mathrm{COV}_{\mathrm{IM}}$ & $\mathrm{TDH}$ & $\mathrm{TDH}_{\mathrm{IM}}$ \\
$(\mathrm{gDQO} / \mathrm{L})$ & $(\mathrm{h})$ & $(\mathrm{L})$ & $(\mathrm{gDQO} / \mathrm{L}$. dia $)$ & $(\mathrm{gDQO} / \mathrm{L}$. dia $)$ & $(\mathrm{dia})$ & $($ dia $)$ \\
\hline 1,398 & 12 & 2,01 & 1,034 & 2,778 & 1,35 & 0,50 \\
\hline
\end{tabular}

A FIGURA 5.18 apresenta a eficiência média de remoção de material orgânico desenvolvido pelo sistema e foi feita com base na concentração média do afluente, obtendo-se máximo de $85 \%$ e mínimo de $81 \%$ de eficiência para efluente filtrado e máximo de $84 \%$ e mínimo de $79 \%$ de eficiência para efluente não filtrado, para os 24 dias de sistema operados sob certa condição de estabilidade.

Na FIGURA 5.19 são apresentados os valores de alcalinidade a bicarbonato efluente e a FIGURA 5.20 mostra a concentração de ácidos orgânicos voláteis totais, comparado com os valores afluentes para todos os 31 dias de ensaio.

Como pode ser observado nas figuras e na TABELA 5.9, o sistema recuperou a capacidade tamponante e o consumo de ácidos voláteis se deu quase que totalmente, sendo observado pelo aumento na concentração de metano no biogás. 


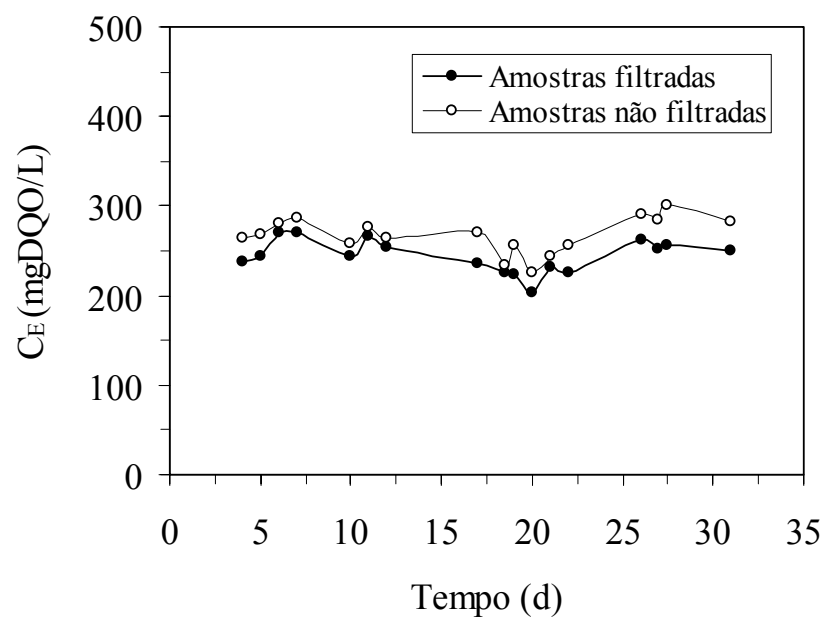

FIGURA 5.17 - Concentração de matéria orgânica efluente para amostras filtrada $\left(\mathrm{C}_{\mathrm{EF}}\right)$ e não filtrada $\left(\mathrm{C}_{\mathrm{ET}}\right)$, para batelada de $12 \mathrm{~h}$ com alimentação de $1500 \mathrm{mgDQO} / \mathrm{L}$.

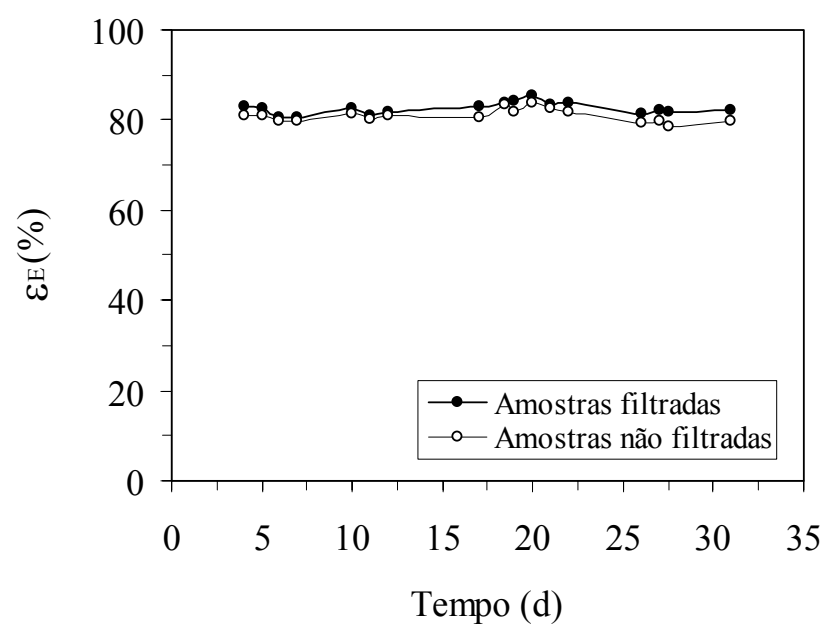

Figura 5.18 - Eficiência de remoção de material orgânico para amostras filtrada $\left(\varepsilon_{\mathrm{EF}}\right) \mathrm{e}$ não filtrada $\left(\varepsilon_{\mathrm{ET}}\right)$, para batelada de $12 \mathrm{~h}$ com alimentação de $1500 \mathrm{mgDQO} / \mathrm{L}$. 


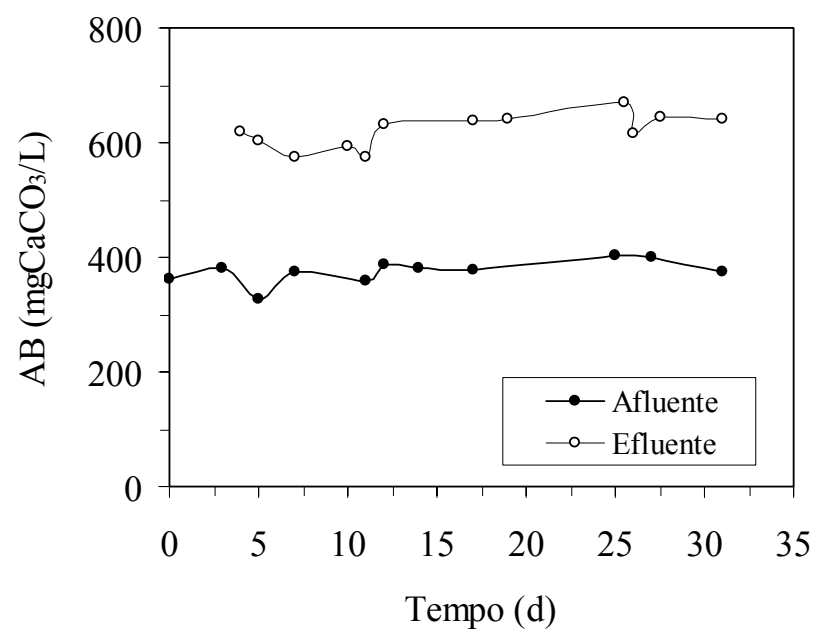

FIGURA 19. - Alcalinidade a bicarbonato (AB) efluente e afluente, para batelada de 12 h com alimentação 1500 mgDQO/L.

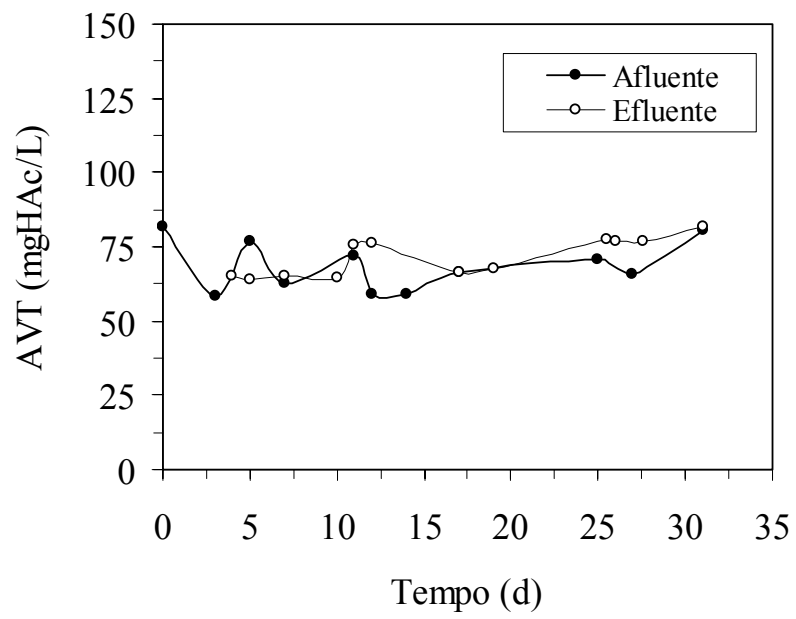

FIGURA 5.20 - Concentração de ácidos voláteis totais (AVT) efluente e afluente, para batelada de 12 h com alimentação de 1500 mgDQO/L. 


\subsection{Concentração Afluente de $1000 \mathrm{mgDQO} / \mathrm{L}$ e ciclos de $12 \mathrm{~h}$}

Na sexta condição de trabalho, o reator foi operado e monitorado durante um período de 31 dias, sendo observada estabilidade nas variáveis monitoradas ao fim do $7^{\circ}$ dia de operação. Desta forma, pode-se acompanhar o sistema operando há 24 dias sob condições estáveis. Os valores originais para construção da tabelas e figuras apresentadas nessa seção encontram-se nas TABELAS II.11 e II.12 do APÊNDICE II, TABELAS III.11 e III.12 do APÊNDICE III e TABELAS IV.19, IV.20, IV.21 e IV.22 do APÊNDICE IV.

A TABELA 5.11 resume os valores médios das variáveis monitoradas, lembrando que as médias afluentes são referentes a todos os valores obtidos, enquanto que as médias efluentes são referentes aos últimos 24 dias de operação. A TABELA 5.12 apresenta os valores dos parâmetros operacionais calculados para essa condição experimental, conforme equacionamento proposto anteriormente.

Na FIGURA 5.21 são apresentados valores da concentração de substrato efluente, para amostras filtradas e não filtradas. Como pode ser observada, após o $7^{\circ}$ dia de operação, a DQO filtrada apresentou valor médio de $124 \pm 11 \mathrm{mg} / \mathrm{L}$ (máximo de 193 mg/L e mínimo de $107 \mathrm{mg} / \mathrm{L}$ ) e DQO não filtrada de $144 \pm 13 \mathrm{mg} / \mathrm{L}$ (máximo de 257 mg/L e mínimo $124 \mathrm{mg} / \mathrm{L})$.

A FIGURA 5.22 apresenta a eficiência média de remoção de material orgânico e foi feita com base na concentração média do afluente, obtendo-se máximo de $89 \%$ e mínimo de $81 \%$ de eficiência para efluente filtrado e máximo de $87 \%$ e mínimo de 74 
\% de eficiência para efluente não filtrado, para os 24 dias do sistema operado sob certa estabilidade operacional das condições monitoradas.

TABELA 5.11 - Variáveis monitoradas no ensaio do ASBR com biomassa imobilizada, operado com batelada de $12 \mathrm{~h}$ com alimentação de 1000 mgDQO/L.

\begin{tabular}{ccc}
\hline Variável & Afluente & Efluente \\
\hline $\mathrm{C}_{\mathrm{ET}}(\mathrm{mgDQO} / \mathrm{L})$ & $992 \pm 79(19)$ & $144 \pm 13(20)$ \\
$\mathrm{C}_{\mathrm{EF}}(\mathrm{mgDQO} / \mathrm{L})$ & - & $124 \pm 11(20)$ \\
$\varepsilon_{\mathrm{ET}}(\%)$ & - & $86 \pm 1(20)$ \\
$\varepsilon_{\mathrm{EF}}(\%)$ & - & $88 \pm 1(20)$ \\
$\mathrm{AB}(\mathrm{mgCaCO} / \mathrm{L})$ & $251 \pm 24(9)$ & $448 \pm 10(10)$ \\
$\mathrm{AVT}(\mathrm{mgHAc} / \mathrm{L})$ & $53 \pm 8(9)$ & $27 \pm 4(10)$ \\
$\mathrm{pH}$ & $8,7 \pm 0,1(9)$ & $7,0 \pm 0,1(10)$ \\
$\mathrm{AI} / \mathrm{AP}$ & $0,26 \pm 0,05(9)$ & $0,25 \pm 0,05(10)$ \\
$\mathrm{ST}(\mathrm{mg} / \mathrm{L})$ & $1563 \pm 281(10)$ & $1167 \pm 73(8)$ \\
$\mathrm{SVT}(\mathrm{mg} / \mathrm{L})$ & $763 \pm 216(10)$ & $296 \pm 31(8)$ \\
$\mathrm{SST}(\mathrm{mg} / \mathrm{L})$ & $58 \pm 16(5)$ & $41 \pm 9(5)$ \\
$\mathrm{SSV}(\mathrm{mg} / \mathrm{L})$ & $56 \pm 23(7)$ & $16 \pm 5(6)$ \\
$\mathrm{Volume}(\mathrm{L})$ & - & $2,00 \pm 0,01(19)$ \\
$\mathrm{CH}_{4}(\mathrm{mMol} / \mathrm{L})$ & - & $8,8 \pm 0,2(2)$ \\
$\mathrm{CO}_{2}(\mathrm{mMol} / \mathrm{L})$ & - & $4,2 \pm 0,2(2)$ \\
$\mathrm{CH}_{4}(\%)$ & - & $70 \pm 0(2)$ \\
$\mathrm{CO}_{2}(\%)$ & - & $30 \pm 0(2)$ \\
\hline $\mathrm{OBS}: 0$ & &
\end{tabular}

OBS: O valor entre parênteses é referente ao número de amostras utilizadas para cálculo da média e do desvio padrão. 
TABELA 5.12- Parâmetros operacionais calculados para a sexta condição operacional.

\begin{tabular}{ccccccc}
\hline $\begin{array}{c}\mathrm{C}_{\mathrm{ST}} \\
(\mathrm{gST} / \mathrm{g} \text { esp. })\end{array}$ & $\begin{array}{c}\mathrm{C}_{\mathrm{SVT}} \\
(\mathrm{gSVT} / \mathrm{g} \text { esp. })\end{array}$ & $\begin{array}{c}\gamma \\
(\mathrm{g} \text { esp./g esp. Inoc. })\end{array}$ & $\begin{array}{c}\mathrm{M}_{\mathrm{INOC}} \\
(\mathrm{g} \text { esp. Inoc })\end{array}$ & $\begin{array}{c}\mathrm{X} \\
(\mathrm{gSVT})\end{array}$ & $\begin{array}{c}\mathrm{COE} \\
(\mathrm{gDQO} / \mathrm{gSVT} . \text { dia })\end{array}$ \\
\hline 1631 & 1441 & 0,02431 & 1819 & 64 & 0,062 \\
\hline $\mathrm{C}_{\mathrm{A}}$ & $\mathrm{t}_{\mathrm{C}}$ & $\mathrm{V}_{\mathrm{ALI}}$ & $\mathrm{COV}$ & $\mathrm{COV}_{\mathrm{IM}}$ & $\mathrm{TDH}$ & $\mathrm{TDH}_{\mathrm{IM}}$ \\
$(\mathrm{gDQO} / \mathrm{L})$ & $(\mathrm{h})$ & $(\mathrm{L})$ & $(\mathrm{gDQO} / \mathrm{L}$. dia $)$ & $(\mathrm{gDQO} / \mathrm{L}$. dia $)$ & $($ dia $)$ & $($ dia $)$ \\
\hline 0,992 & 12 & 2,00 & 0,735 & 1,984 & 1,34 & 0,50 \\
\hline
\end{tabular}

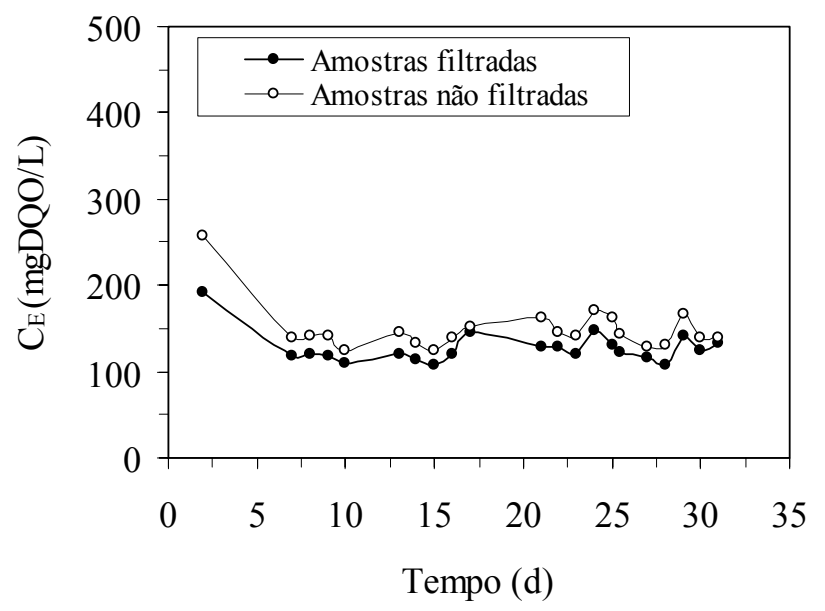

FIGURA 5.21 - Concentração de matéria orgânica efluente para amostras filtrada $\left(\mathrm{C}_{\mathrm{EF}}\right)$ e não filtrada $\left(\mathrm{C}_{\mathrm{ET}}\right)$, para batelada de $12 \mathrm{~h}$ com alimentação de $1000 \mathrm{mgDQO} / \mathrm{L}$.

Na FIGURA 5.23 e 5.24 são apresentados os valores de alcalinidade a bicarbonato efluente e a concentração de ácidos voláteis totais, respectivamente, comparados com os valores afluentes para todos os 31 dias de ensaio. 


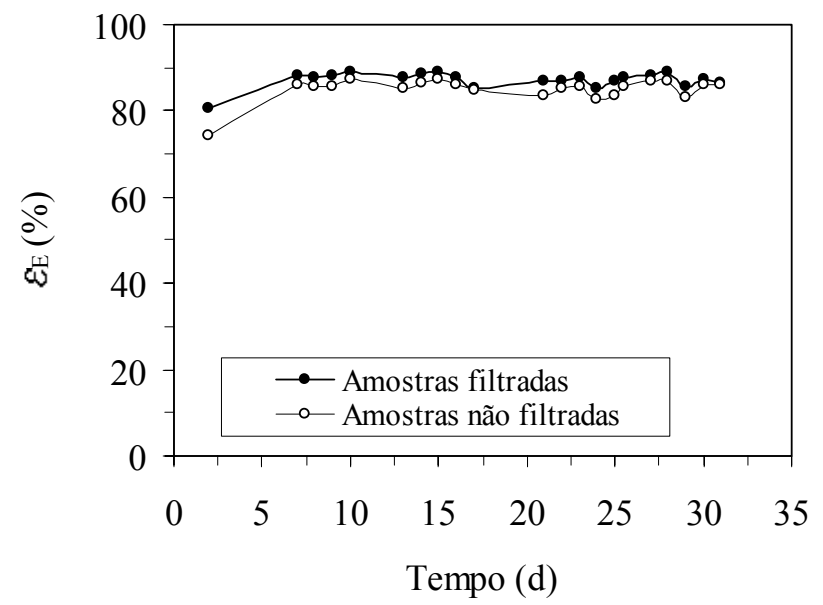

Figura 5.22 - Eficiência de remoção de material orgânico para amostras filtrada $\left(\varepsilon_{\mathrm{EF}}\right) \mathrm{e}$ não filtrada $\left(\varepsilon_{\mathrm{ET}}\right)$, para batelada de $12 \mathrm{~h}$ com alimentação de 1000 mgDQO/L.

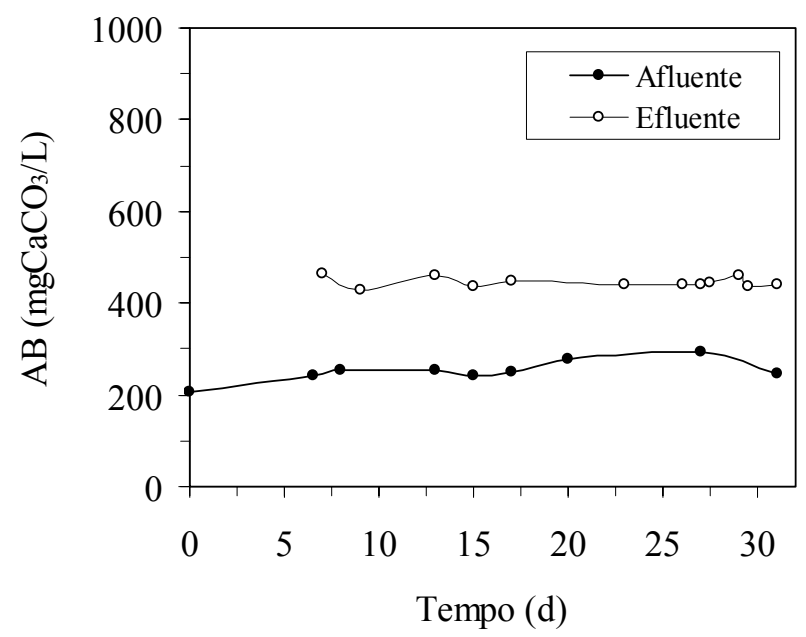

FIGURA 5.23 - Alcalinidade a bicarbonato (AB) efluente e afluente, para batelada de 12 h com alimentação 1000 mgDQO/L. 


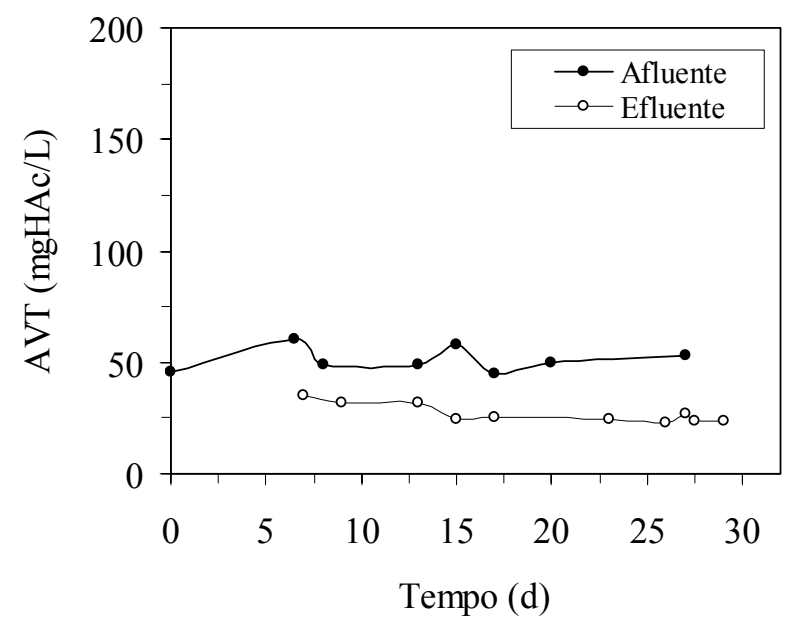

FIGURA 5.24 - Concentração de ácidos voláteis totais (AVT) efluente e afluente, para batelada de 12 h com alimentação de 1000 mgDQO/L.

\subsection{Desempenho do ASBR Submetido a Diferentes Valores de COV}

A TABELA 5.13 apresenta os resultados médios para todas as condições de operação e a FIGURA 5.25 compara os valores da concentração de material orgânico efluente para amostras filtradas e não filtradas, com os valores afluentes durante todos os dias em que o equipamento foi operado.

Como pode ser observado, à medida que se aumentou a $\mathrm{COV}_{\mathrm{IM}}$ aplicada ao sistema, este demonstrou perda na eficiência de remoção de matéria orgânica para amostras filtradas. Tal fato se deve, possivelmente, ao acúmulo de produtos orgânicos reduzidos, referentes à etapa acidogênica, tais como ácidos orgânicos voláteis e, que não são convertidas a metano. Desta forma, uma parcela da DQO efluente na condição de $\mathrm{COV}_{\mathrm{IM}}$ de 5,4 gDQO/L.dia poderia ser relacionada com tal fato. 
TABELA 5.13 - Valores médios das concentrações de material orgânico para amostras afluentes e efluentes, eficiência de remoção de material orgânico para amostras filtradas e volume médio descarregado por batelada para todas as condições aplicadas.

\begin{tabular}{ccccccc}
\hline $\mathrm{COV}_{\mathrm{IM}}{ }^{(*)}$ & $\mathrm{C}_{\mathrm{A}}{ }^{(\mathrm{a})}$ & \multicolumn{2}{c}{$\mathrm{C}_{\mathrm{E}}{ }^{(\mathrm{b})}(\mathrm{mgDQO} / \mathrm{L})$} & $\varepsilon_{\mathrm{E}}{ }^{(\mathrm{b})}(\%)$ & $\mathrm{V}_{\text {Total }}{ }^{(\mathrm{c})}$ \\
\cline { 3 - 5 }$(\mathrm{gCOD} / \mathrm{L} . \mathrm{dia})$ & $(\mathrm{mgDQO} / \mathrm{L})$ & $\mathrm{C}_{\mathrm{ET}}$ & $\mathrm{C}_{\mathrm{EF}}$ & $\varepsilon_{\mathrm{ET}}(\%)$ & $\varepsilon_{\mathrm{EF}}(\%)$ & $(\mathrm{L})$ \\
\hline 1,5 & $492 \pm 49$ & $73 \pm 14$ & $61 \pm 12$ & $85 \pm 3$ & $88 \pm 3$ & $2,00 \pm 0,07$ \\
2,9 & $962 \pm 84$ & $315 \pm 71$ & $264 \pm 59$ & $67 \pm 7$ & $73 \pm 6$ & $1,99 \pm 0,05$ \\
5,4 & $1811 \pm 146$ & $844 \pm 97$ & $810 \pm 98$ & $53 \pm 5$ & $55 \pm 5$ & $2,03 \pm 0,04$ \\
3,6 & $1808 \pm 108$ & $385 \pm 25$ & $352 \pm 21$ & $79 \pm 1$ & $81 \pm 1$ & $2,01 \pm 0,05$ \\
2,8 & $1398 \pm 111$ & $266 \pm 22$ & $243 \pm 19$ & $81 \pm 2$ & $83 \pm 1$ & $2,01 \pm 0,04$ \\
1,9 & $992 \pm 79$ & $144 \pm 13$ & $124 \pm 11$ & $86 \pm 1$ & $88 \pm 1$ & $2,00 \pm 0,01$ \\
\hline
\end{tabular}

${ }^{(*)}$ Período de ensaio (dias): 48/67/20/35/31/31.

Número de amostras: ${ }^{\text {(a) }} 27 / 37 / 11 / 15 / 19 / 19 ;{ }^{\text {(b) }} 15 / 19 / 15 / 7 / 14 / 20 ;{ }^{(c)} 15 / 17 / 15 / 15 / 12 / 19$.

Quanto à remoção de substrato, pode-se dizer que para condições em que a concentração de matéria orgânica afluente foi igual, como é o caso da segunda e sexta condições e para a terceira e quarta condições, operações com maiores tempos de ciclo resultaram em maiores eficiências de remoção. Para condições com $\operatorname{COV}_{\mathrm{IM}}$ iguais, caso da segunda e quinta condições, maiores tempos de batelada resultaram em efluentes com menores concentrações de matéria orgânica, mesmo operados com concentrações afluentes maiores. 


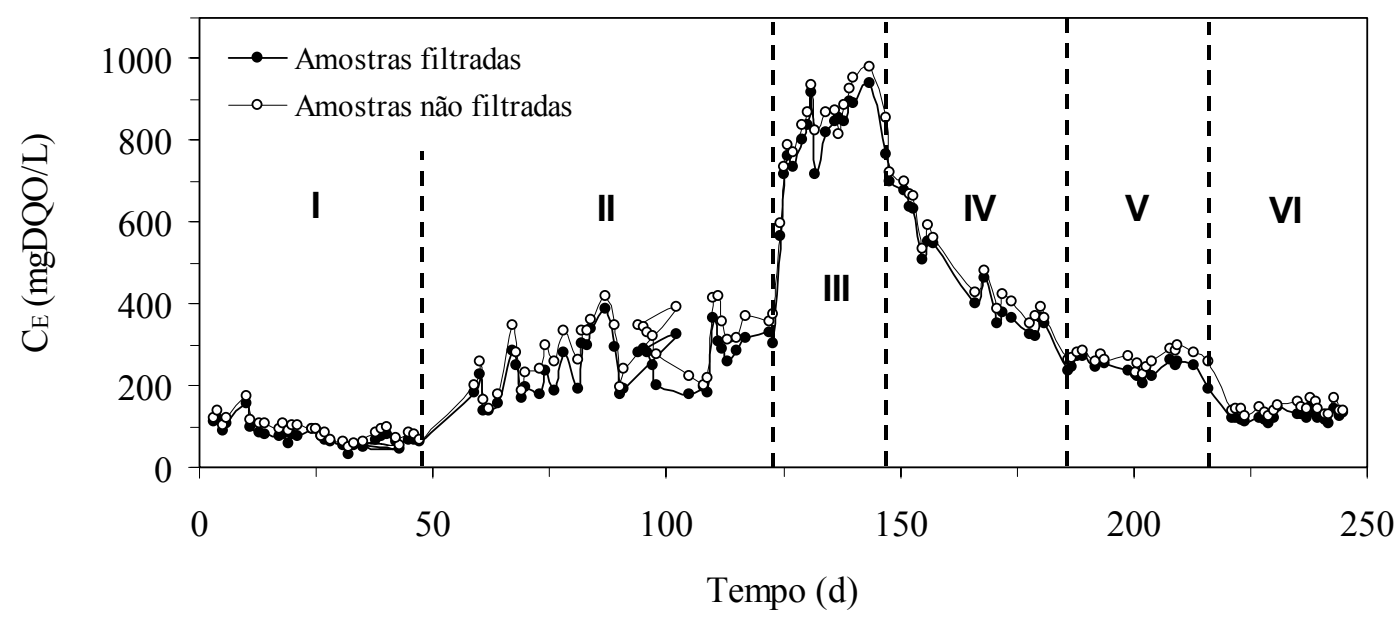

FIGURA 5.25 - Concentrações de matéria orgânica efluente para as condições operacionais. Bateladas de $8 \mathrm{~h}$ e concentrações afluentes de (I) $500 \mathrm{mgDQO} / \mathrm{L}$, (II) 1000 mgDQO/L, (III) 2000 mgDQO/L. Bateladas de 12 h e concentrações afluentes de (IV) $2000 \mathrm{mgDQO} / \mathrm{L},(\mathrm{V}) 1500 \mathrm{mgDQO} / \mathrm{L} \mathrm{e}(\mathrm{VI}) 1000 \mathrm{mgDQO} / \mathrm{L}$.

A TABELA 5.14 apresenta a média da alcalinidade a bicarbonato, a concentração de ácidos voláteis totais e a relação AI/AP, monitorados para todas as etapas de operação do sistema ASBR com biomassa imobilizada em suporte inerte.

$\mathrm{O}$ valor e a estabilidade do $\mathrm{pH}$ no reator anaeróbio são extremamente importantes, pois velocidades elevadas de metanogênese só podem ser desenvolvidas quando o pH se mantém numa faixa estreita, perto do valor neutro, como foi observado para todos os estágios de operação.

A TABELA 5.14 traz ainda valores de outro parâmetro importante para inferir sobre a estabilidade operacional do sistema, que é a relação AI/AP. Como AI constituise principalmente da alcalinidade a ácidos voláteis, assim como AP representa, 
primordialmente, a alcalinidade a bicarbonato, baixos valores dessa relação indicam a estabilidade do processo.

TABELA 5.14 - Valores médios de alcalinidades a bicarbonato, concentração de ácidos voláteis totais e relação AI/AP para afluente e efluente, em todas as condições estudadas.

\begin{tabular}{|c|c|c|c|c|c|c|c|c|}
\hline \multirow{2}{*}{$\begin{array}{l}\operatorname{COV}_{\mathrm{IM}}{ }^{(*)} \\
(\mathrm{gDQO} / \mathrm{L} \cdot \mathrm{d})\end{array}$} & \multicolumn{2}{|c|}{$\begin{array}{c}\mathrm{AB} \\
\left(\mathrm{mgCaCO}_{3} / \mathrm{L}\right)\end{array}$} & \multicolumn{2}{|c|}{$\begin{array}{c}\text { AVT } \\
(\mathrm{mgHAc} / \mathrm{L})\end{array}$} & \multicolumn{2}{|c|}{$\mathrm{pH}$} & \multicolumn{2}{|c|}{$\mathrm{AI} / \mathrm{AP}$} \\
\hline & $\mathrm{Afl}^{(\mathrm{a})}$ & Efl. $^{(b)}$ & Afl. $^{(a)}$ & Efl. $^{(b)}$ & $\mathrm{Afl}^{(\mathrm{a})}$ & Efl. $^{(b)}$ & Afl. ${ }^{(a)}$ & Efl. $^{(b)}$ \\
\hline 1,5 & $126 \pm 7$ & $233 \pm 7$ & $30 \pm 5$ & $19 \pm 1$ & $8,3 \pm 0,7$ & $7,5 \pm 0,1$ & $0,26 \pm 0,06$ & $0,21 \pm 0,03$ \\
\hline 2,9 & $232 \pm 10$ & $377 \pm 34$ & $47 \pm 5$ & $64 \pm 30$ & $8,2 \pm 0,7$ & $7,0 \pm 0,1$ & $0,27 \pm 0,03$ & $0,31 \pm 0,10$ \\
\hline 5,4 & $511 \pm 11$ & $459 \pm 42$ & $84 \pm 7$ & $430 \pm 99$ & $8,5 \pm 0,3$ & $6,8 \pm 0,1$ & $0,27 \pm 0,01$ & $0,69 \pm 0,12$ \\
\hline 3,6 & $466 \pm 11$ & $799 \pm 34$ & $75 \pm 9$ & $96 \pm 12$ & $8,8 \pm 0,1$ & $7,3 \pm 0,3$ & $0,28 \pm 0,02$ & $0,33 \pm 0,02$ \\
\hline 2,8 & $376 \pm 22$ & $623 \pm 32$ & $69 \pm 9$ & $73 \pm 6$ & $8,8 \pm 0,2$ & $7,0 \pm 0,1$ & $0,25 \pm 0,03$ & $0,32 \pm 0,04$ \\
\hline 1,9 & $251 \pm 24$ & $448 \pm 10$ & $53 \pm 8$ & $27 \pm 4$ & $8,7 \pm 0,1$ & $7,0 \pm 0,1$ & $0,26 \pm 0,05$ & $0,25 \pm 0,05$ \\
\hline
\end{tabular}

${ }^{(*)}$ Período de ensaio (dias): 48/67/20/35/31/31.

Número de amostras: ${ }^{(a)} 15 / 11 / 7 / 7 / 11 / 9 ;{ }^{(b)} 6 / 10 / 11 / 4 / 10 / 10$.

A FIGURA 5.26 apresenta os valores da alcalinidade a bicarbonato para todas as condições $\mathrm{COV}_{\mathrm{IM}}$ impostas ao sistema. A produção de alcalinidade a bicarbonato se mostrou presente em todas as condições impostas, exceto para a condição de carregamento orgânico volumétrico $\left(\mathrm{COV}_{\mathrm{IM}}\right)$ máxima de 5,4 gDQO/L.dia, na qual se observou um déficit de alcalinidade a bicarbonato comparado com o valor afluente. A razão para o consumo de solução tamponante, representada pela concentração de alcalinidade a bicarbonato e, possivelmente, o aumento na DQO efluente para esta etapa operacional, pode ser explicada pelo acúmulo de ácidos volateis. 


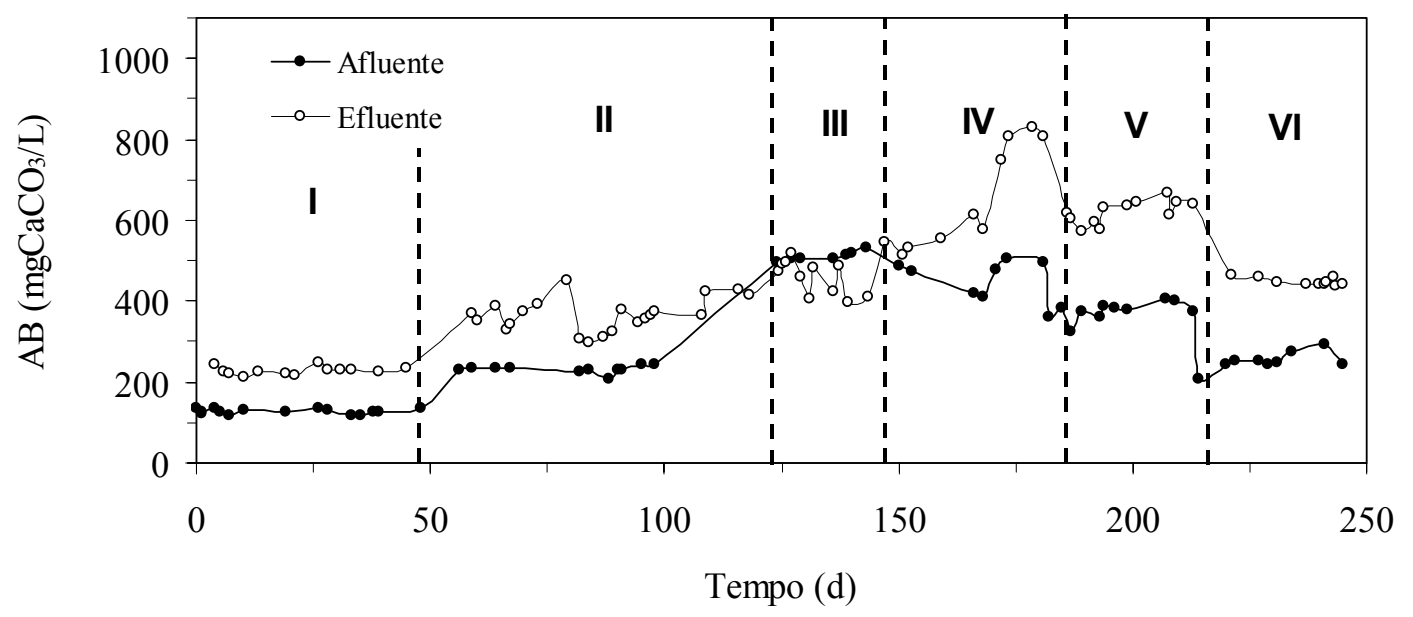

FIGURA 5.26 - Concentrações de alcalinidade a bicarbonato para as condições operacionais. Bateladas de $8 \mathrm{~h}$ e concentrações afluentes de (I) $500 \mathrm{mgDQO} / \mathrm{L}$, (II) 1000 mgDQO/L, (III) 2000 mgDQO/L. Bateladas de 12 h e concentrações afluentes de (IV) 2000 mgDQO/L, (V) 1500 mgDQO/L e (VI) 1000 mgDQO/L.

Mesmo havendo o consumo de alcalinidade a bicarbonato, o valor afluente foi suficiente para garantir o tamponamento do meio reacional próximo da neutralidade, como pode ser observado nos valores do $\mathrm{pH}$ apresentados.

A FIGURA 5.27 apresenta os valores da concentração de ácidos voláteis totais para todas as seis condições aplicadas. Pode-se observar que o as 4 horas dadas a mais para o ciclo de 12 horas, comparados as etapas com tempo de ciclo de $8 \mathrm{~h}$, foram suficientes para que os microrganismos consumissem, quase que totalmente, a quantidade de ácidos voláteis totais produzida. 


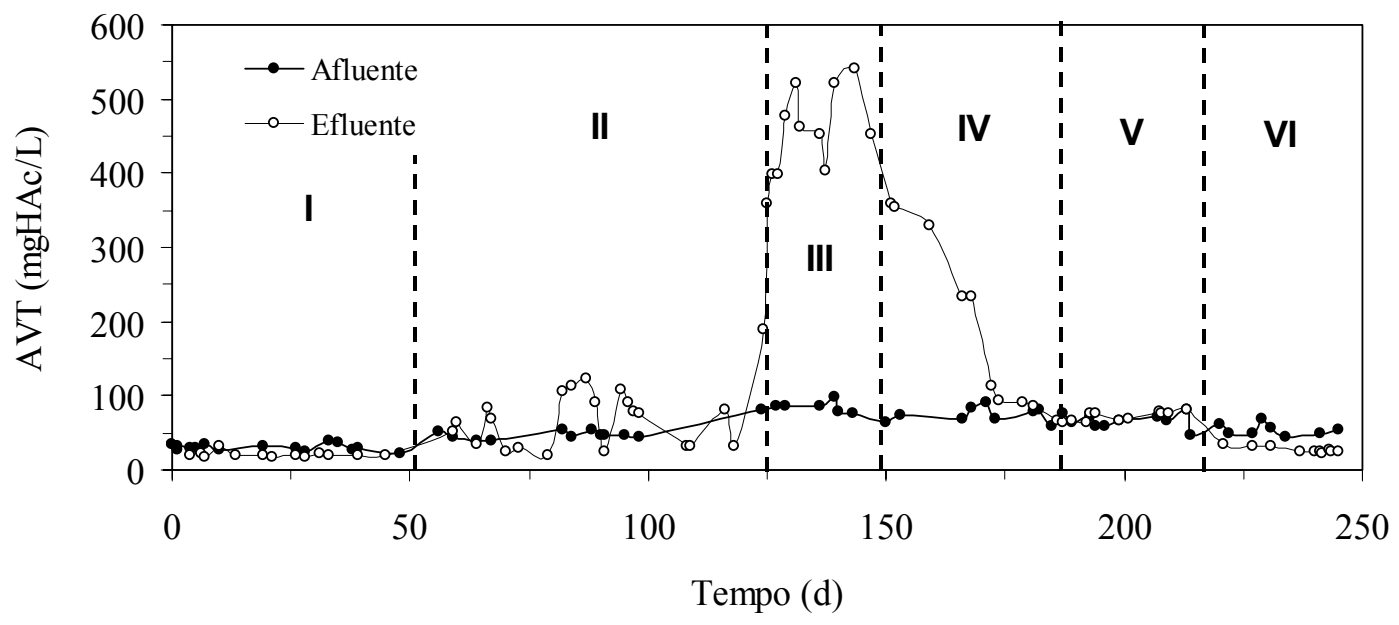

FIGURA 5.27 - Concentrações de ácidos voláteis totais para as condições operacionais.

Bateladas de $8 \mathrm{~h}$ e concentrações afluentes de (I) $500 \mathrm{mgDQO} / \mathrm{L}$, (II) $1000 \mathrm{mgDQO} / \mathrm{L}$, (III) 2000 mgDQO/L. Bateladas de 12 h e concentrações afluentes de (IV) 2000 mgDQO/L, (V) 1500 mgDQO/L e (VI) 1000 mgDQO/L.

Portanto, as seguintes observações podem ser feitas: para o mesmo valor de $\mathrm{COV}_{\mathrm{IM}}$, com concentrações afluentes e tempos de batelada diferentes, não houve diferenças significativas quanto à estabilidade operacional, mostrando a flexibilidade operacional do sistema operado em batelada; para operação com concentrações afluentes iguais e temos de ciclo diferentes (segunda e sexta condições com $\mathrm{C}_{\mathrm{A}}$ de aproximadamente $1000 \mathrm{mgDQO} / \mathrm{L}$ e terceira e quinta condições, com $\mathrm{C}_{\mathrm{A}}$ de aproximadamente $2000 \mathrm{mgDQO} / \mathrm{L}$ ), o tempo a mais para o ciclo reacional é fundamental para o consumo dos ácidos voláteis totais e restabelecimento do poder tamponante inicial. 


\subsection{Perfis das Variáveis Monitoradas ao Longo da Batelada}

\subsubsection{Perfil de Alcalinidade a Bicarbonato}

A FIGURAS 5.28 compara os perfis de alcalinidade a bicarbonato para todas as condições experimentais aplicadas.

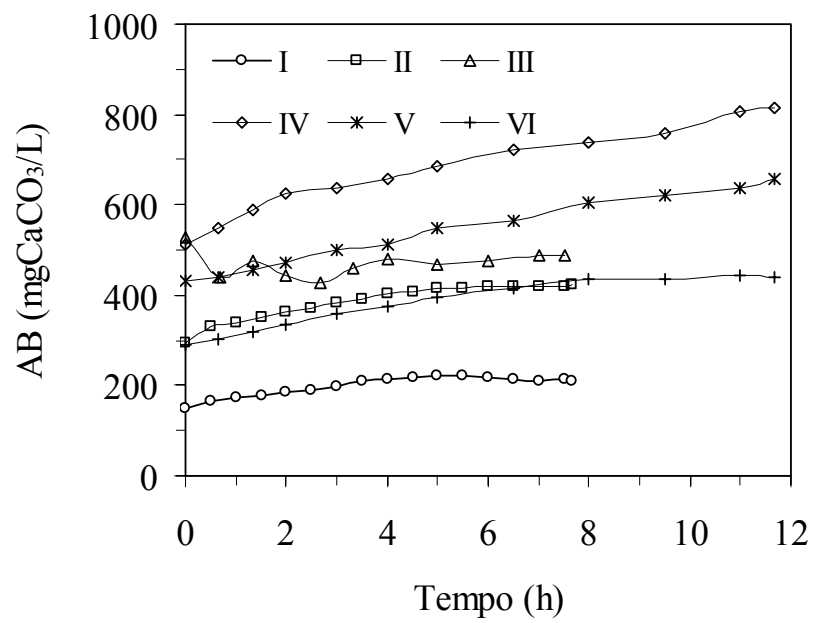

FIGURA 5.28 - Perfis médios de alcalinidade a bicarbonato. Bateladas de 8 h e concentrações afluentes de (I) 500 mgDQO/L, (II) 1000 mgDQO/L, (III) 2000 mgDQO/L. Bateladas de 12 h e concentrações afluentes de (IV) 2000 mgDQO/L, (V) $1500 \mathrm{mgDQO} / \mathrm{L} \mathrm{e} \mathrm{(VI)} 1000 \mathrm{mgDQO} / \mathrm{L}$.

Como pode ser observado, os perfis médios de alcalinidade a bicarbonato apresentaram respostas semelhantes para as condições de operação, variando apenas na magnitude do valor alcançado em determinado período de reação. Isso se deve as 
concentrações de alcalinidade a bicarbonato afluente para cada condição. Para os casos estudados, a recuperação da alcalinidade a bicarbonato se deu no momento em que os ácidos voláteis totais iam sendo consumidos.

A exceção ocorreu para a terceira condição experimental $\left(\mathrm{C}_{\mathrm{A}}\right.$ de $2000 \mathrm{mgDQO} / \mathrm{L}$ e $t_{C}$ de $8 \mathrm{~h}$ ), na qual o acúmulo de ácidos produzidos, além de consumir a alcalinidade afluente, inibi os microrganismos acetogênicos, que tem no bicarbonato um de seus produtos.

\subsubsection{Perfil de Concentração de Ácidos Voláteis}

A FIGURAS 5.29 compara os perfis da concentração de ácidos voláteis para todas as condições experimentais aplicadas.

Pode-se verificar nas figuras que a produção de ácidos voláteis se deu logo no início da batelada, mostrando quão rápida é a etapa acidogênica. Em seguida, verifica-se o consumo de tais ácidos e produção de metano, como será apresentado a seguir. Operando-se o reator com uma concentração afluente de $2000 \mathrm{mgDQO} / \mathrm{L}$ e bateladas de 8 horas (terceira condição), verificou-se o acúmulo de ácidos voláteis totais. Para a condição seguinte, alimentando-se o reator com a mesma concentração afluente, mas com bateladas de 12 horas, as quatro horas a mais foram suficientes para que todo o ácido produzido fosse consumido. 


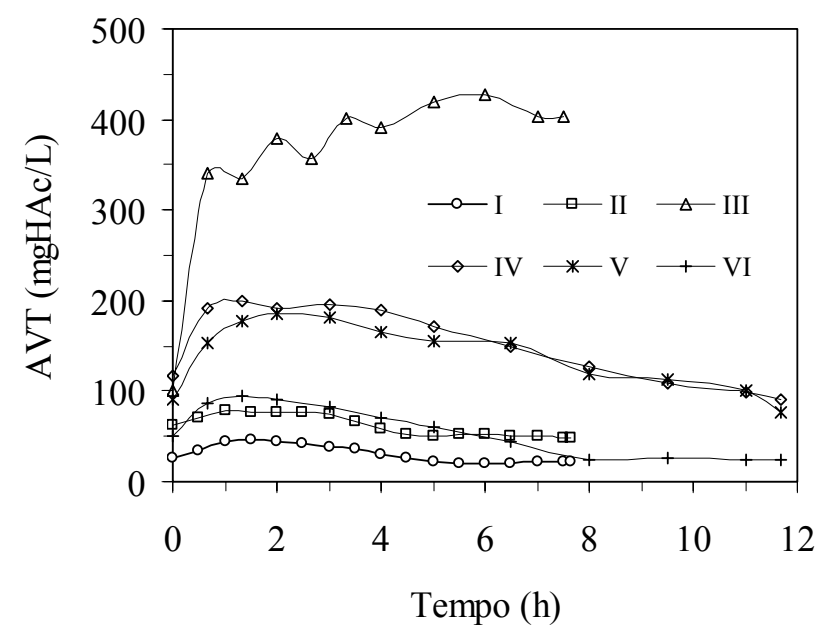

FIGURA 5.29 - Perfis médios da concentração de ácidos voláteis totais. Bateladas de 8

h e concentrações afluentes de(I) 500 mgDQO/L, (II) 1000 mgDQO/L, (III) 2000 mgDQO/L. Bateladas de 12 h e concentrações afluentes de (IV) 2000 mgDQO/L, (V) $1500 \mathrm{mgDQO} / \mathrm{L} \mathrm{e} \mathrm{(VI)} 1000 \mathrm{mgDQO} / \mathrm{L}$.

\subsubsection{Perfil de Composição do Biogás}

As FIGURAS 5.30 e 5.31 mostram os perfis das concentrações de metano e dióxido de carbono e nas FIGURAS 5.32 e 5.33 são apresentadas as frações molares desses gases, contidos no "head-space" do reator.

Pelas figuras podemos observar a inibição da etapa metanogênica, para a terceira condição experimental, devido à redução na produção e metano e aumento na concentração de dióxido de carbono. Como se tratou de uma condição na qual se aplicou grande carregamento orgânico, as frações molares no final de ciclo caíram para 59\% de 
metano e $41 \%$ de dióxido de carbono, confirmando a hipótese de que o material orgânico afluente estava sendo convertido a ácidos voláteis ao invés de metano.

Para carregamentos orgânicos menores, as frações molares foram de71 \% para metano e 29 \% para dióxido de carbono, na quinta e sexta condições experimentais.

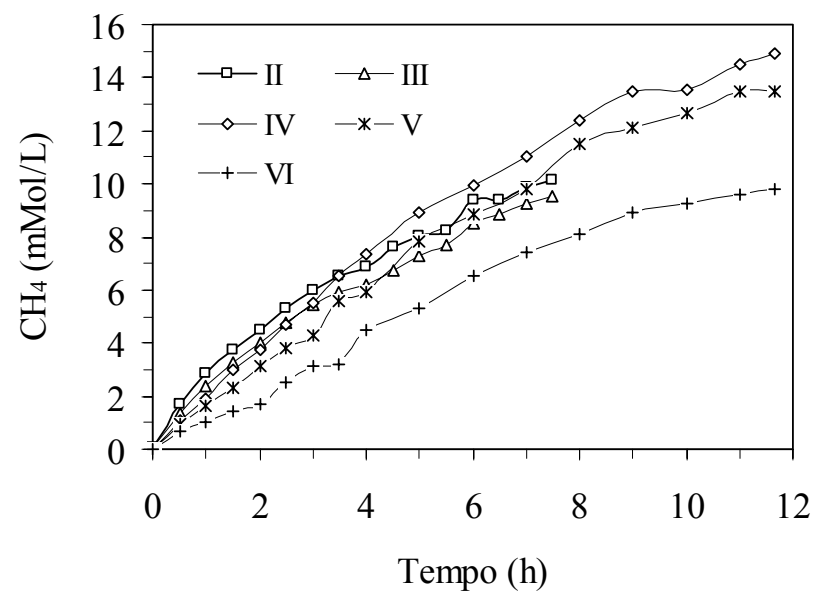

FIGURA 5.30 - Perfis médios das concentrações de metano. Bateladas de 8 h e concentrações afluentes de (II) 1000 mgDQO/L, (III) 2000 mgDQO/L. Bateladas de 12 h e concentrações afluentes de (IV) 2000 mgDQO/L, (V) 1500 mgDQO/L e (VI) $1000 \mathrm{mgDQO} / \mathrm{L}$. 


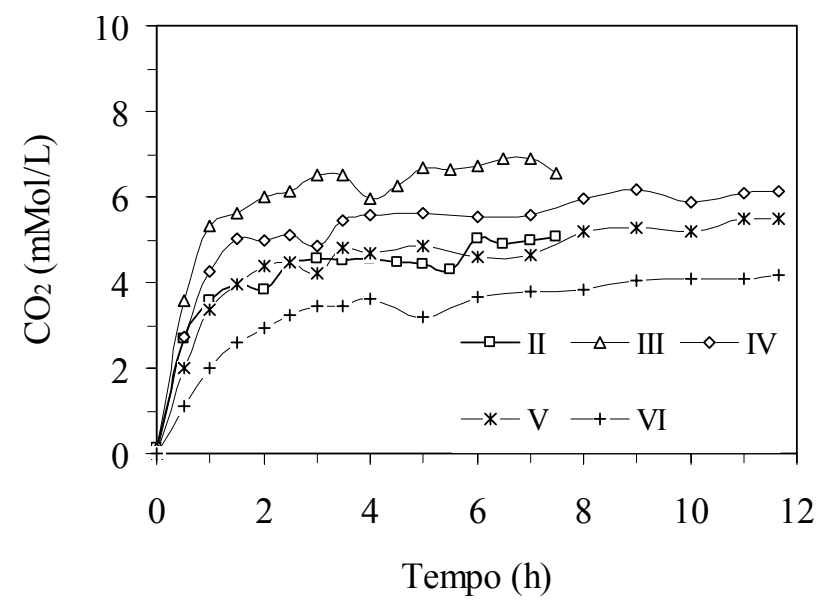

FIGURA 5.31 - Perfis médios da concentração de dióxido de carbono. Bateladas de $8 \mathrm{~h}$ e concentrações afluentes de (II) $1000 \mathrm{mgDQO} / \mathrm{L}$, (III) $2000 \mathrm{mgDQO} / \mathrm{L}$. Bateladas de $12 \mathrm{~h}$ e concentrações afluentes de (IV) $2000 \mathrm{mgDQO} / \mathrm{L}$, (V) $1500 \mathrm{mgDQO} / \mathrm{L} \mathrm{e}$ (VI) $1000 \mathrm{mgDQO} / \mathrm{L}$.

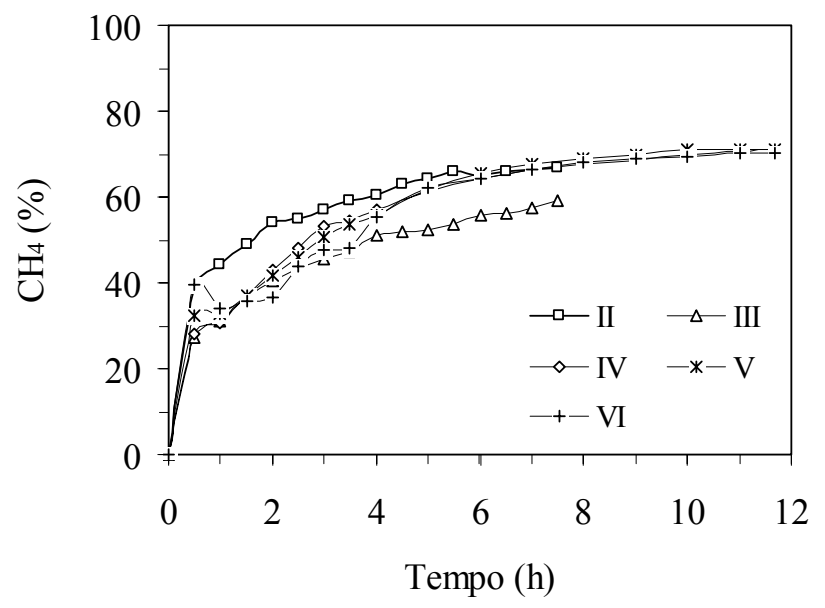

FIGURA 5.32 - Perfis médios das frações molares de metano. Bateladas de $8 \mathrm{~h}$ e concentrações afluentes de (II) 1000 mgDQO/L, (III) 2000 mgDQO/L. Bateladas de 12 h e concentrações afluentes de (IV) 2000 mgDQO/L, (V) 1500 mgDQO/L e (VI) $1000 \mathrm{mgDQO} / \mathrm{L}$. 


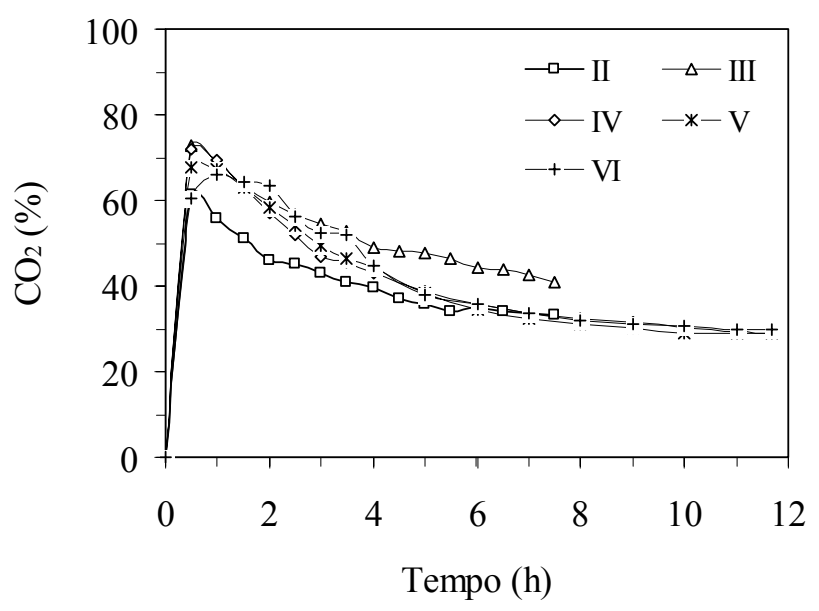

FIGURA 5.33 - Perfis médios das frações molares de dióxido de carbono. Bateladas de $8 \mathrm{~h}$ e concentrações afluentes de (II) $1000 \mathrm{mgDQO} / \mathrm{L}$, (III) $2000 \mathrm{mgDQO} / \mathrm{L}$. Bateladas de 12 h e concentrações afluentes de (IV) 2000 mgDQO/L, (V) 1500 mgDQO/L e (VI) 1000 mgDQO/L.

\subsubsection{Perfil de Remoção de Matéria Orgânica}

A FIGURA 5.34 apresenta os valores da concentração de matéria orgânica efluente para amostras filtrada durante a batelada. Para a primeira condição, observa-se que, após 5 horas, o sistema já se mostrava estabilizado, com uma eficiência de conversão para o perfil acima de $80 \%$, para concentração no tempo zero de análise de $374 \mathrm{mgDQO} / \mathrm{L}$.

Para a segunda e sexta condições operacionais, alimentadas com mesma concentração afluente, porém com tempos de ciclo diferente, observa-se que os perfis apresentados foram idênticos para as oito primeiras horas, com uma eficiência máxima 
de conversão para o perfil de $71 \%$ e $81 \%$, respectivamente. As concentração no tempo zero de análise foram de $720 \mathrm{mgDQO} / \mathrm{L}$, para a segunda e $655 \mathrm{mgDQO} / \mathrm{L}$ para a sexta condição.

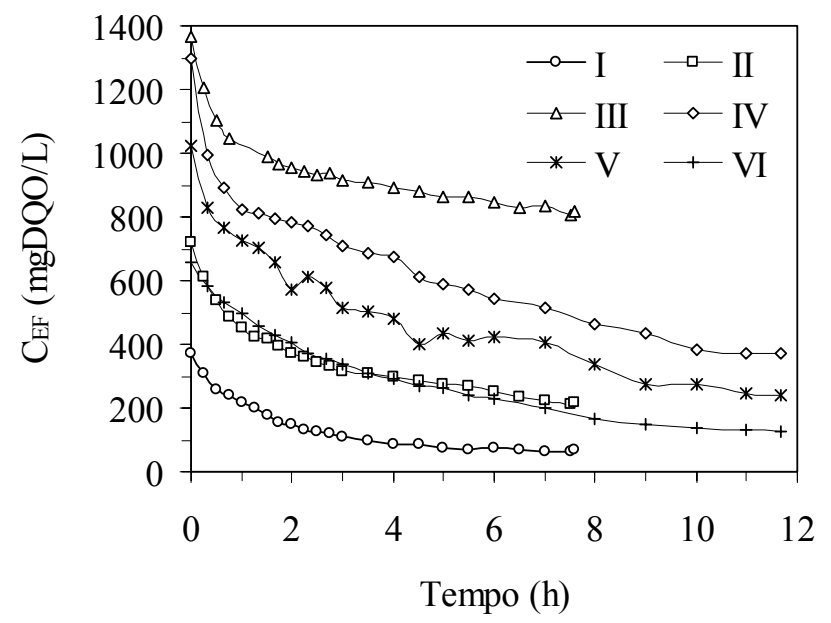

FIGURA 5.34 - Perfis médios de material orgânico efluente para amostras filtradas.

Bateladas de $8 \mathrm{~h}$ e concentrações afluentes de (I) $500 \mathrm{mgDQO} / \mathrm{L}$, (II) $1000 \mathrm{mgDQO} / \mathrm{L}$, (III) 2000 mgDQO/L. Bateladas de 12 h e concentrações afluentes de (IV) 2000 mgDQO/L, (V) 1500 mgDQO/L e (VI) 1000 mgDQO/L.

Para a terceira e quarta etapas, também com concentrações afluentes iguais, podemos observar claramente a redução na eficiência de remoção de material orgânico para a terceira etapa. Isso se deve possivelmente à produção excessiva de ácidos voláteis totais, principalmente os ácidos butírico e propiônico, formados principalmente em casos de sobrecarga orgânica (DILALLO \& ALBERTSON, 1961). Como estes ácidos não são os produtos principais da metânogênese, a eficiência de remoção e substrato cai 
drasticamente, como pode ser observado no perfil de metano. As eficiências máximas de remoção de material orgânico no perfil e concentrações de substrato no efluente para amostras filtradas foram de $41 \%$ e $804 \mathrm{mgDQO} / \mathrm{L}$ e $72 \%$ e $369 \mathrm{mgDQO} / \mathrm{L}$, respectivamente para a terceira e quarta condições operacionais.

Para a quinta condição operacional, foram registradas eficiências máximas de remoção de material orgânico de 76 \%, com base numa concentração média no tempo zero de reação de $1020 \mathrm{mgDQO} / \mathrm{L}$.

Os dados dos perfis de concentração de efluente para as amostras filtradas foram ajustados a um modelo cinético de primeira ordem. O parâmetro cinético $\left(k_{1}\right)$, é aparente pois inclui em sua síntese os fenômenos de resistências a transferência de massa interna e externa, bem como os termos cinéticos intrínsecos da conversão bioquímica. Como apresentado, para verificação de melhores ajustes do modelo não lineares aos pontos experimentais, foram utilizadas duas estratégias para ajuste dos pontos experimentais ao modelo: (a) manter constantes as concentrações de substrato inicial $\left(\mathrm{C}_{\mathrm{So}}\right)$ e resídual $\left(\mathrm{C}_{\mathrm{SR}}\right)$ no ajuste do modelo, conforme valores observados nos perfis e (b) manter somente a concentração inicial de substrato constante, sendo $\mathrm{C}_{\mathrm{SR}}$ uma variável no modelo, bem como $\mathrm{k}_{1}$.

As FIGURAS 5.35 a 5.40 apresentam os ajustes do modelo aos valores experimentais obtidos com os perfis da concentração de substrato efluente para as amostras filtradas em todas as seis condições empregadas, utilizando as duas estratégias descritas. 


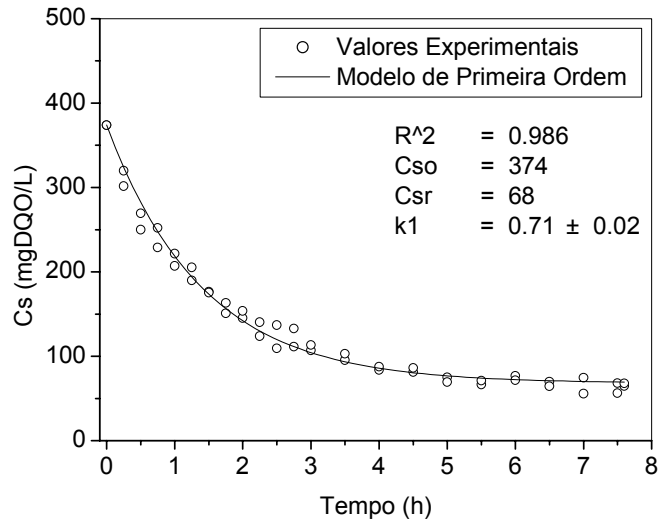

(a)

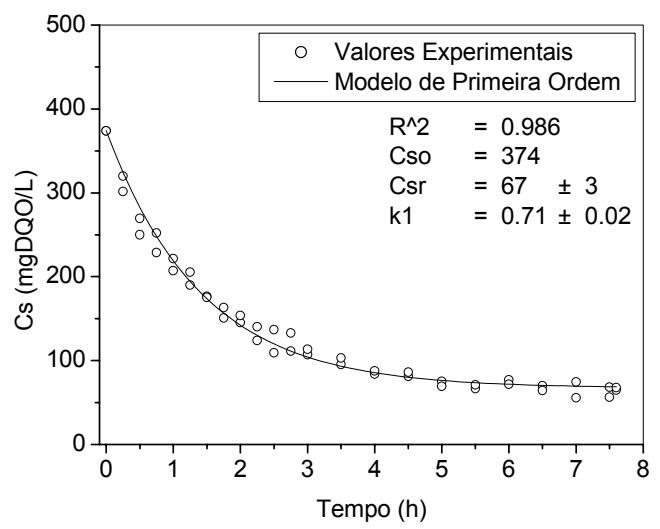

(b)

FIGURA 5.35 - Ajuste do modelo de cinético de primeira ordem aos valores experimentais. Condição de alimentação com concentração afluente de 500 mgDQO/L em bateladas de $8 \mathrm{~h}$. (a) $\mathrm{C}_{\mathrm{So}}$ e $\mathrm{C}_{\mathrm{SR}}$ constantes e (b) $\mathrm{C}_{\mathrm{So}}$ constante e $\mathrm{C}_{\mathrm{SR}}$ como variável.

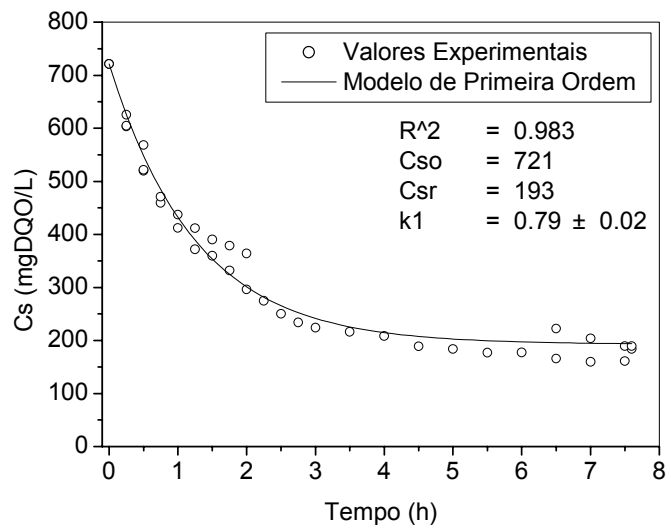

(a)

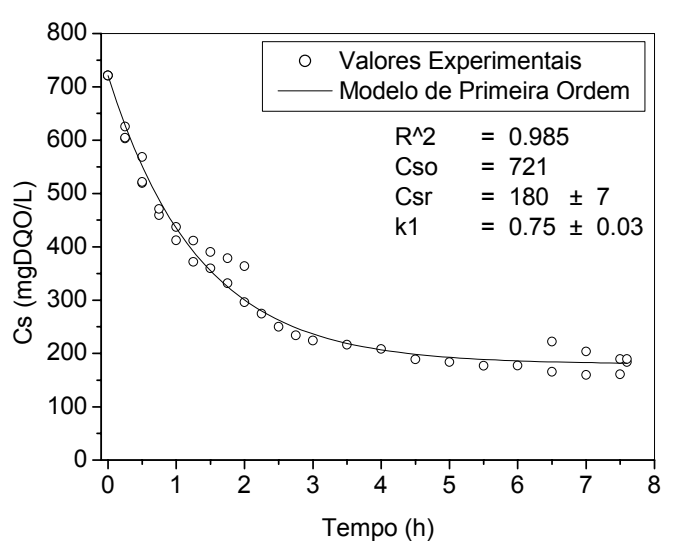

(b)

FIGURA 5.36 - Ajuste do modelo de cinético de primeira ordem aos valores experimentais. Condição de alimentação com concentração afluente de 1000 mgDQO/L em bateladas de $8 \mathrm{~h}$. (a) $\mathrm{C}_{\mathrm{So}}$ e $\mathrm{C}_{\mathrm{SR}}$ constantes e (b) $\mathrm{C}_{\mathrm{So}}$ constante e $\mathrm{C}_{\mathrm{SR}}$ como variável. 


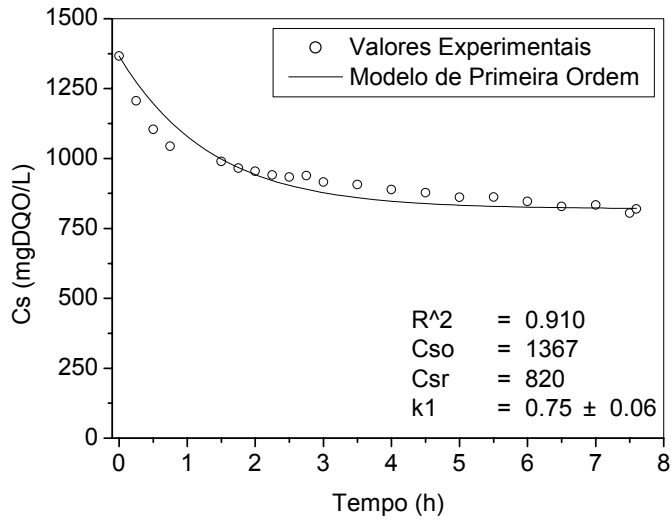

(a)

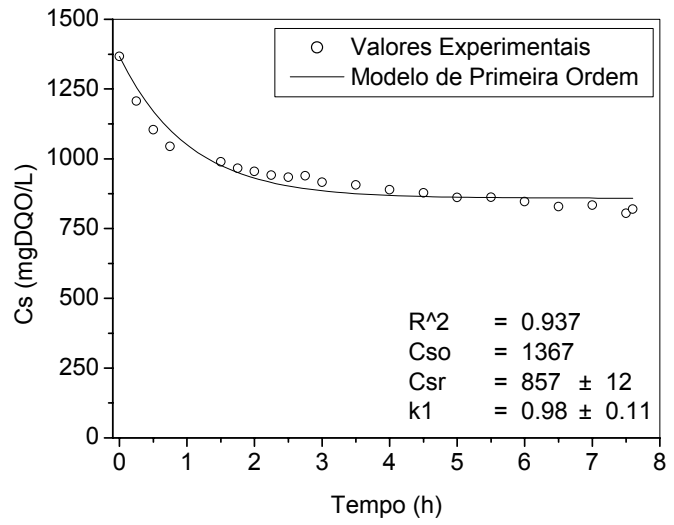

(b)

FIGURA 5.37 - Ajuste do modelo de cinético de primeira ordem aos valores experimentais. Condição de alimentação com concentração afluente de 2000 mgDQO/L em bateladas de $8 \mathrm{~h}$. (a) $\mathrm{C}_{\mathrm{So}}$ e $\mathrm{C}_{\mathrm{SR}}$ constantes e (b) $\mathrm{C}_{\mathrm{So}}$ constante e $\mathrm{C}_{\mathrm{SR}}$ como variável.

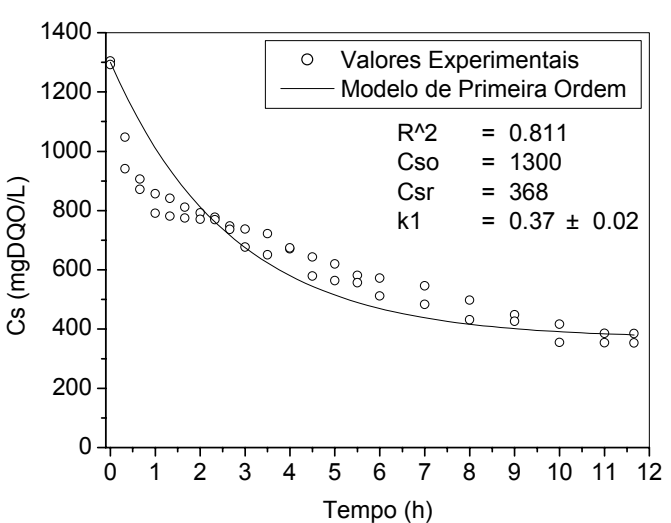

(a)

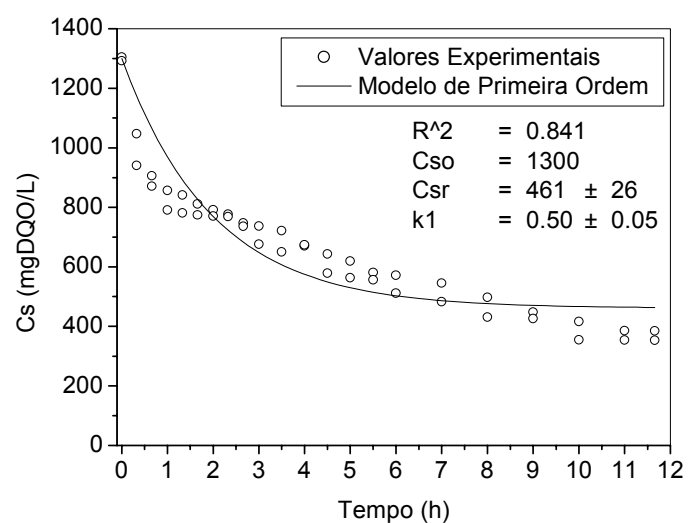

(b)

FIGURA 5.38 - Ajuste do modelo de cinético de primeira ordem aos valores experimentais. Condição de alimentação com concentração afluente de 2000 mgDQO/L em bateladas de $12 \mathrm{~h}$. (a) $\mathrm{C}_{\mathrm{So}}$ e $\mathrm{C}_{\mathrm{SR}}$ constantes e (b) $\mathrm{C}_{\mathrm{So}}$ constante e $\mathrm{C}_{\mathrm{SR}}$ como variável. 


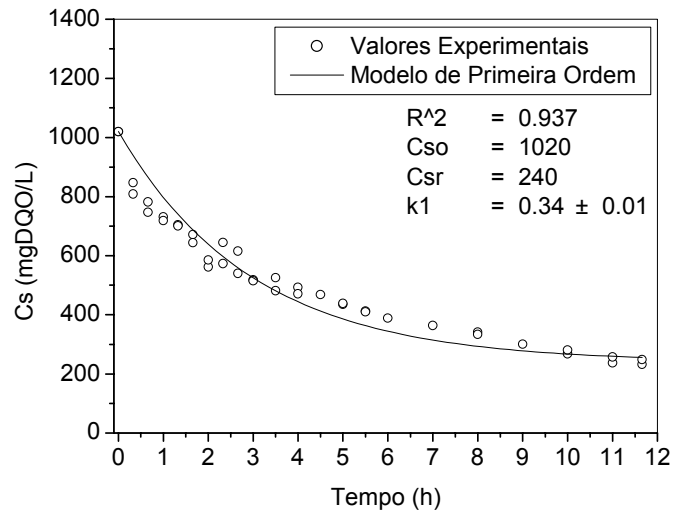

(a)

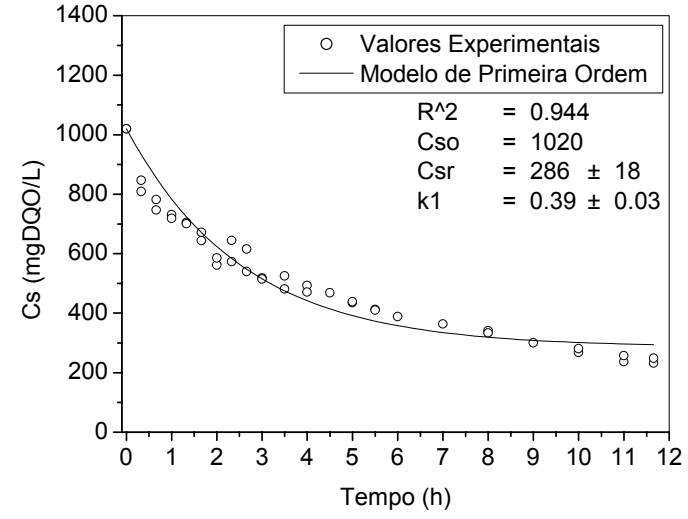

(b)

FIGURA 5.39 - Ajuste do modelo de cinético de primeira ordem aos valores experimentais. Condição de alimentação com concentração afluente de 1500 mgDQO/L em bateladas de $12 \mathrm{~h}$. (a) $\mathrm{C}_{\mathrm{So}}$ e $\mathrm{C}_{\mathrm{SR}}$ constantes e (b) $\mathrm{C}_{\mathrm{So}}$ constante e $\mathrm{C}_{\mathrm{SR}}$ como variável.

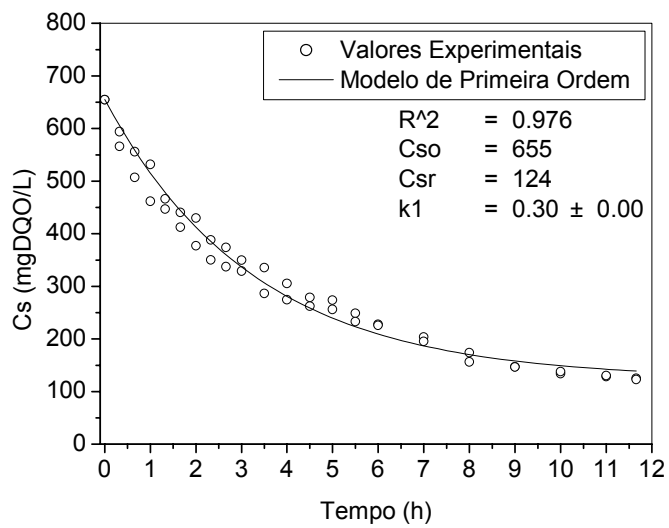

(a)

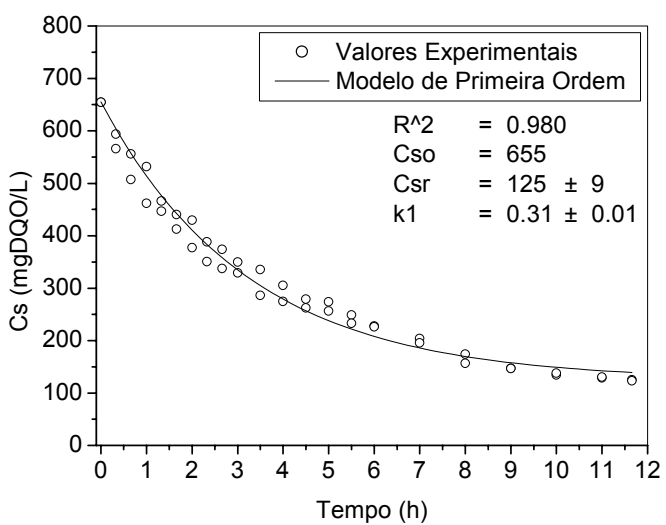

(b)

FIGURA 5.40 - Ajuste do modelo de cinético de primeira ordem aos valores experimentais. Condição de alimentação com concentração afluente de 1000 mgDQO/L em bateladas de $12 \mathrm{~h}$. (a) $\mathrm{C}_{\mathrm{So}}$ e $\mathrm{C}_{\mathrm{SR}}$ constantes e (b) $\mathrm{C}_{\mathrm{So}}$ constante e $\mathrm{C}_{\mathrm{SR}}$ como variável. 
A TABELA 5.15 resume os valores obtidos para a constante cinética, para as duas situações calculadas, ou seja, (a) pelo ajuste do modelo aos dados experimentais, mantendo-se os valores da concentração de substrato residual $\left(\mathrm{C}_{\mathrm{SR}}\right)$ constante e iguais as médias dos valores observados ao final do perfil; e (b) estimativa de ambos, parâmetro cinético aparente $\left(\mathrm{k}_{1}\right)$ e concentração de substrato residual $\left(\mathrm{C}_{\mathrm{SR}}\right)$ pelo ajuste do modelo aos dados experimentais.

Como pode ser observado nas figuras apresentadas e na TABELA 5.12, o quadrado do coeficiente de correlação $\left(\mathrm{r}^{2}\right)$ apresentado não mostrou grandes variações para os dois modos de ajuste ("a" e "b"). Porém, as figuras mostram que, para todos os casos exceto a primeira condição operacional, não se verificou a formação de um patamar estável em torno da concentração de substrato efluente residual. Desta forma, considerou-se mais prudente e confiável avaliar os dados referentes ao ajuste do modelo em que $\mathrm{C}_{\mathrm{SR}}$ foi ajustado como uma variável (caso “b”), assim como $\mathrm{k}_{1}$.

Para a terceira condição experimental, na qual se verificou o maior valor de $\mathrm{k}_{1}$, a matéria orgânica afluente foi rapidamente convertida a ácidos voláteis. Devido à sobrecarga orgânica aplicada nesta condição, estes ácidos não foram convertidos a metano, sendo lidos no efluente como uma medida de demanda química de oxigênio. Assim, como a $\mathrm{C}_{\mathrm{SR}}$ se estabilizou em poucas horas, para o modelo ajustado esta foi a etapa na qual se verificaram altas velocidades de conversão.

Para a segunda e sexta etapas operacionais, alimentadas com mesma concentração afluente (1000 mgDQO/L), o tempo a mais dado para o ciclo (8 h para 12 h) não foi suficiente para que a $C_{S R}$ se estabilizasse num patamar estável. Desta forma, 
como o modelo ajustou $\mathrm{k}_{1}$ baseado em 8 horas para a segunda etapa, este teve um valor superior do registrado para a sexta etapa, com $12 \mathrm{~h}$ de ciclo.

Devido ao fato do sistema ter sido alimentado com concentrações afluentes diferentes e serem observados valores de $\mathrm{C}_{\mathrm{SR}}$ variados, mesmo para os casos em que se alimentava com concentrações afluentes iguais, não se faz possível uma comparação entre os valores de $\mathrm{k}_{1}$.

TABELA 5.15 - Valores obtidos para a constante cinética específica aparente $\left(\mathrm{k}_{1}\right)$, calculada pelo ajuste do modelo cinético de primeira ordem aos valores experimentais.

\begin{tabular}{|c|c|c|c|c|c|c|c|}
\hline \multirow{3}{*}{$\begin{array}{c}\mathrm{COV}_{\mathrm{IM}} \\
(\mathrm{gDQO} / \mathrm{L} . \mathrm{dia})\end{array}$} & \multirow{3}{*}{$\begin{array}{c}\mathrm{C}_{\mathrm{So}} \\
(\mathrm{mgDQO} / \mathrm{L})\end{array}$} & \multicolumn{3}{|c|}{ (a) } & \multicolumn{3}{|c|}{ (b) } \\
\hline & & \multicolumn{3}{|c|}{$\mathrm{k}_{1}$ como variável } & \multicolumn{3}{|c|}{$\mathrm{C}_{\mathrm{SR}}$ e $\mathrm{k}_{1}$ como variável } \\
\hline & & $\begin{array}{c}\mathrm{C}_{\mathrm{SR}} \\
(\mathrm{mgDQO} / \mathrm{L})\end{array}$ & $\mathrm{k}_{1}\left(\mathrm{~h}^{-1}\right)$ & $r^{2}$ & $\begin{array}{c}\mathrm{C}_{\mathrm{SR}} \\
(\mathrm{mgDQO} / \mathrm{L})\end{array}$ & $\mathrm{k}_{1}\left(\mathrm{~h}^{-1}\right)$ & $r^{2}$ \\
\hline 1,5 & 374 & 68 & $0,71 \pm 0,02$ & 0,986 & $67 \pm 3$ & $0,71 \pm 0,02$ & 0,986 \\
\hline 2,9 & 721 & 193 & $0,79 \pm 0,02$ & 0,983 & $180 \pm 7$ & $0,75 \pm 0,03$ & 0,985 \\
\hline 5,4 & 1367 & 820 & $0,74 \pm 0,06$ & 0,910 & $857 \pm 12$ & $0,98 \pm 0,11$ & 0,937 \\
\hline 3,6 & 1300 & 368 & $0,37 \pm 0,02$ & 0,811 & $461 \pm 26$ & $0,50 \pm 0,05$ & 0,841 \\
\hline 2,8 & 1020 & 240 & $0,33 \pm 0,01$ & 0,937 & $286 \pm 18$ & $0,39 \pm 0,03$ & 0,944 \\
\hline 1,9 & 655 & 124 & $0,30 \pm 0,00$ & 0,976 & $125 \pm 9$ & $0,31 \pm 0,01$ & 0,980 \\
\hline
\end{tabular}

$\mathrm{r}^{2}$ - quadrado do coeficiente de correlação. 


\subsection{Análises Microbiológicas}

Ao final da segunda (bateladas de 8 horas com concentração afluente de 1000 mgDQO/L) e quinta (bateladas de 12 horas com concentração afluente de 1500 mgDQO/L) condições operacionais, amostras de espuma inoculada foram retiradas de diferentes regiões do reator, e analisadas por microscopia ótica comum e de contraste de fases por fluorescência. Devido ao fato das duas condições experimentais não terem apresentado diferenças qualitativas quanto à morfologia microbiana, ambas serão analisadas sem discriminação.

Diferentes morfologias foram observadas nas matrizes porosas durante as análises por microscopia ótica comum e microscopia ótica de contraste de fases por fluorescência. As principais morfologias observadas são apresentadas nas FIGURAS 5.41. a 5.44. Foram detectadas as presenças morfologias semelhantes ao gênero Methanosaeta sp. (FIGURA 5.43), Methanosarcina sp. (FIGURAS 5.42 e 5.43), bacilos hidrogenotróficos (FIGURA 5.41) além de outros microrganismos como cocobacilos não fluorescentes e víbrios.

A presença de microrganismos acetoclásticas e hidrogenotróficas indica o equilíbrio na comunidade metanogênica dentro do consórcio microbiano responsável pela digestão anaeróbia. 


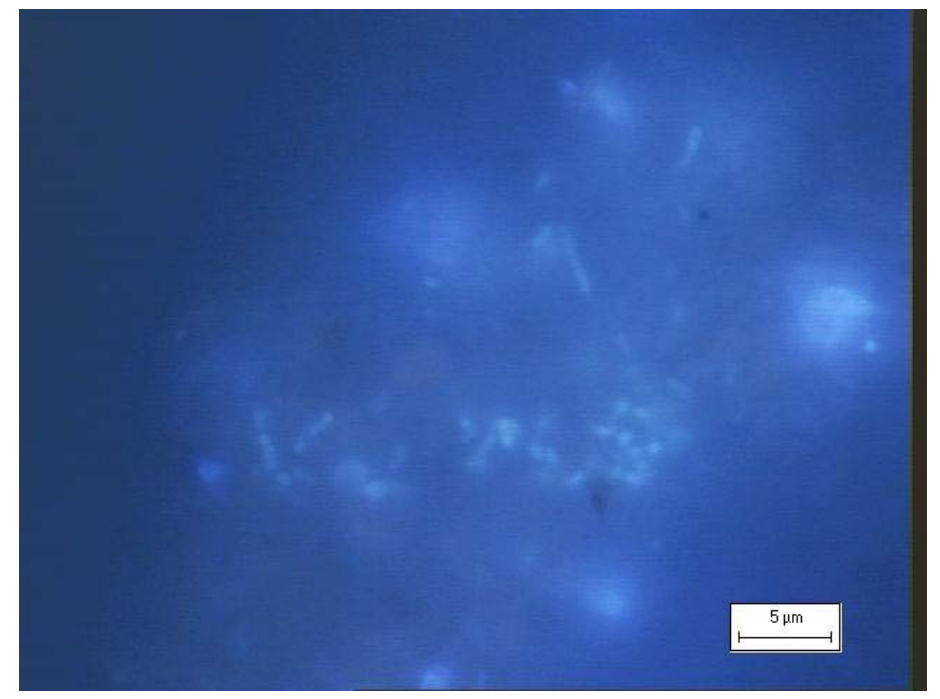

FIGURA 5.41 - Morfologias microbiana por microscopia ótica de contraste de fases.

Células semelhantes a bacilos hidrogenotróficos.

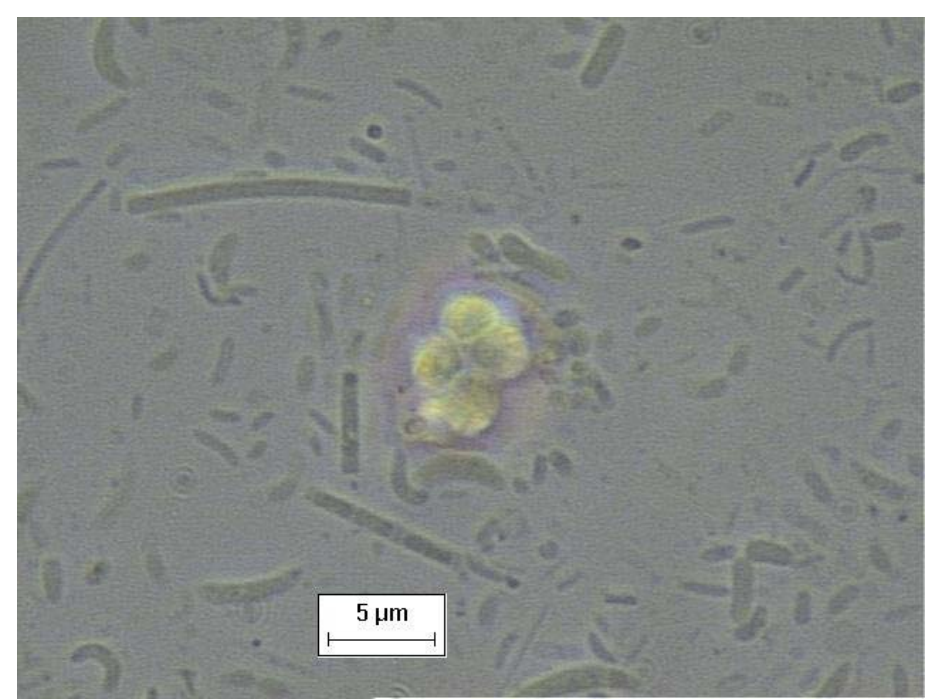

FIGURA 5.42- Morfologias microbiana por microscopia ótica comum. Células semelhantes a Methanoarcina sp. 


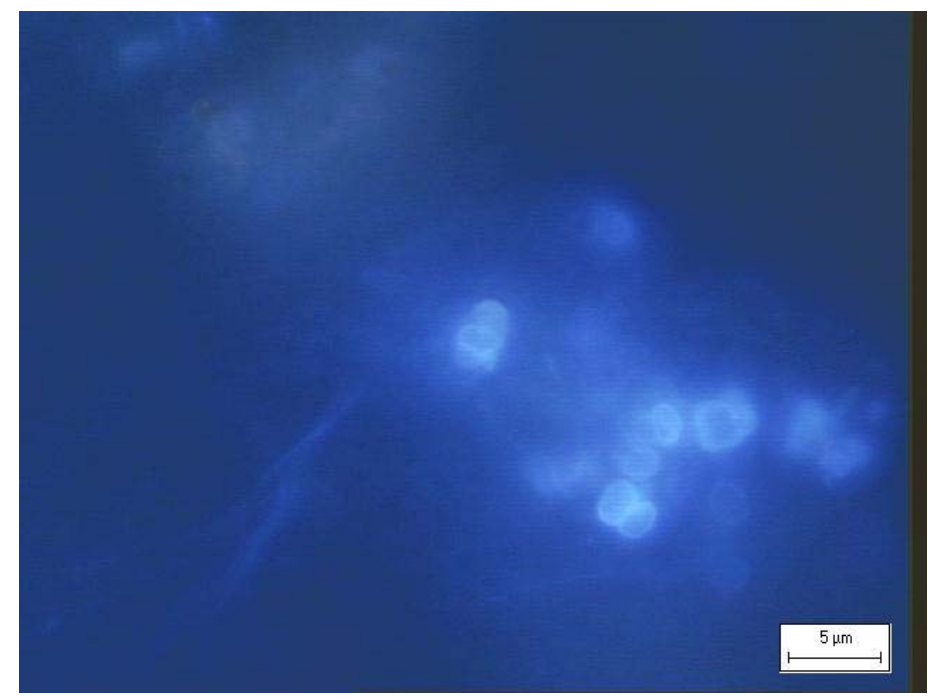

FIGURA 5.43 - Morfologias microbiana por microscopia ótica de contraste de fases.

Células semelhantes a Methanoarcina sp.

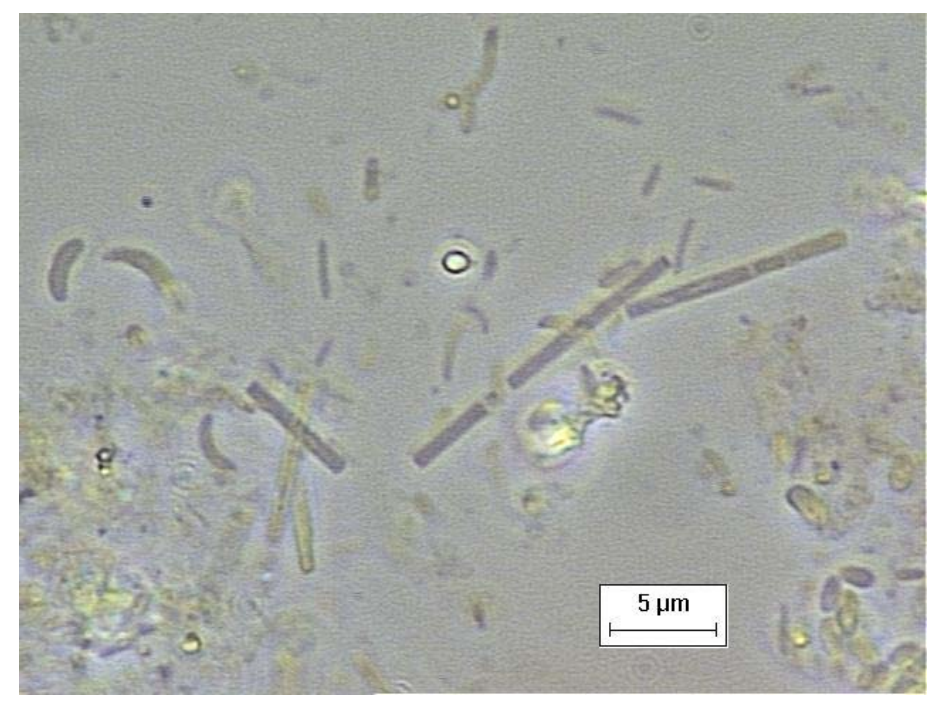

FIGURA 5.44 - Morfologias microbiana por microscopia ótica comum. Filamentos semelhantes a Methanosaeta sp e víbrios. 


\section{CAPÍTULO 6}

\section{CONCLUSÕES E SUGESTÕES}

Os resultados obtidos com a operação do reator anaeróbio permitem concluir que:

- O sistema se mostrou eficiente na remoção de matéria orgânica, com valores entre 81 e $88 \%$ de eficiência para amostras de efluente filtrado para condições de alimentação com concentração afluente variando de 1000 a 2000 mgDQO/L em bateladas de $12 \mathrm{~h}$ e valores entre 73 e $88 \%$ de eficiência para amostras de efluente filtrado para condições de alimentação com concentração afluente variando entre 500 a 1000 mgDQO/L. Para a condição de alimentação com concentração afluente de 2000 $\mathrm{mgDQO} / \mathrm{L}$ em bateladas de $8 \mathrm{~h}\left(\mathrm{COV}_{\mathrm{IM}}\right.$ de 5,4 gDQO/L.dia), observou-se queda na qualidade do efluente, sendo que a remoção média de material orgânico foi de $55 \%$ e efluente com $810 \mathrm{mgDQO} / \mathrm{L}$ para as amostras filtradas.

- Quanto à estabilidade operacional, verificou-se que houve produção de alcalinidade a bicarbonato, ao se comparar com valores no afluente, para todas as condições estudadas e consumo de ácidos voláteis totais, exceto para a alimentação com concentração afluente de $2000 \mathrm{mgDQO} / \mathrm{L}$ e bateladas de $8 \mathrm{~h}\left(\mathrm{COV}_{\mathrm{IM}}\right.$ de 5,4 gDQO/L). 
Porém, a estabilidade operacional foi mantida, devido à concentração de alcalinidade a bicarbonato afluente ser superior a necessária para tamponar o sistema no $\mathrm{pH}$ adequado a digestão anaeróbia.

- O sistema se mostrou eficiente na retenção de biomassa dentro do reator para todos os carregamentos aplicados, o que pode ser observado pelo decréscimo nos valores destes parâmetros efluentes, comparados com o afluente.

- Para sistemas com mesmo $\mathrm{COV}_{\mathrm{IM}}$, porém carregados com concentrações afluentes e tempos de ciclo diferentes $\left(\mathrm{C}_{\mathrm{A}}\right.$ de $1000 \mathrm{mgDQO} / \mathrm{L}$ com $\mathrm{t}_{\mathrm{C}}$ de $8 \mathrm{~h}$ e $\mathrm{C}_{\mathrm{A}}$ de $1500 \mathrm{mgDQO} / \mathrm{L}$ com $\mathrm{t}_{\mathrm{C}}$ de $12 \mathrm{~h}$ ), a concentração de substrato para as amostras de efluente filtrado não apresentou grandes diferenças. Porém, a produção inicial de ácidos voláteis totais foi mais acentuada para o caso de alimentação com maior concentração afluente.

- Para sistemas alimentados com concentração afluente igual, porém com tempos de ciclo diferentes $\left(\mathrm{COV}_{\mathrm{IM}}\right.$ diferentes), as eficiências de remoção de material orgânico foram maiores para sistemas operados com maiores tempos de ciclo, porém os valores dos perfis de remoção de substrato, de alcalinidade a bicarbonato e de concentração de ácidos voláteis totais foram idênticos. E exceção se faz para a concentração de 2000 mg/L operada com bateladas de 8 h, na qual a produção excessiva de ácidos voláteis totais impossibilitou o sistema alcançar grandes eficiências de remoção de material orgânico.

- A análise microbiológica da biomassa, imobilizada nos cubos de espuma de poliuretano, mostrou a presença de biota rica e diversificada, apresentando arqueas do 
gênero Methanosaeta sp, Methanosarcina sp, além de bacilos hidrogenotróficos, cocobacilos não fluorescentes e víbrios.

Baseado nas conclusões e observações feitas durante a execução da etapa experimental, apresentam-se as seguintes sugestões para trabalhos futuros:

- Submeter o sistema a altos carregamentos orgânicos volumétricos, deixando mais tempo para que o reator tente retornar às condições de estabilidade em termos de produção de ácidos voláteis totais e alcalinidade a bicarbonato;

- Estudar os mecanismos de formação do material polimérico de suposta origem biológica nos cubos de espuma de poliuretano; 


\section{CAPÍTULO 7}

\section{REFERÊNCIAS BIBLIOGRÁFICAS}

ANGENENT, L.T.; DAGUE, R.R. (1995). A laboratory- scale comparison of the UASB and ASBR processes. In: $50^{\text {th }}$ Purdue Ind. Wastewater Conference Proceedings, Ann Arbor Press, Chelsea, pp. 365-377.

ANGENENT, L.T.; SUNG, S.; RASKIN, L. (2001). Mixing intensity in anaerobic sequencing batch reactors affects reactor performance and microbial community structure. In: Proceedings of the $9^{\text {th }}$ World Congress on Anaerobic Digestion, Antwerpen, Belgium, pp. 267-274.

ANGENENT, L.T.; SUNG, S.; RASKIN, L. (2002). Methanogenic population dynamics during startup of a full-scale anaerobic sequencing batch reactor treating swine waste. Waste Research, 36, 4648-4654.

APHA; AWWA; WEF (1995). Standard Methods For Examination Of Water And Wastewater. $19^{\text {th }}$ edition. Washington D.C., American Public Health Association.

BAGLEY, D.M.; BRODKORB, T.S. (1999). Modeling microbial kinetics in an anaerobic sequencing batch reactor- Model development and experimental validation. Water Environmental Research, 71, pp.1320-1332. 
BENEFIELD, C.D.; RANDALL, C.W. (1980). Biological process design for wastewater treatment. Prentice- Hall, Inc. Englewood Cliffs, 526p.

BRITO, A.G.; RODRIGUES, A.C.; MELO, L.F. (1997). Feasibility of a pulsed sequencing batch reactor with anaerobic aggregated biomass for the treatment of low strength wastewaters. Water Science and Technology, 35, Vol. I: 193-198

CAMARGO, E.F.M.; RATUSZNEI, S.M.; RODRIGUES, J.A.D.; ZAIAT, M.; BORZANI, W. (2002). Treatment of low-strength wastewater using immobilized biomass im a sequencing batch external loop reactor: Influence of the médium superficial velocit on the stability and performance. Brazilian Journal of Chemical Engineering, 39, No 03, pp.267-275.

CAMPOS, J.R. (1994). Biomassa fixa: Reatores anaeróbios. In: Anais do III Taller y Seminario Latinoamericano- Tratamiento Anaerobio de Aguas Residuales. VIÑHAS, M.; SOUBES, M.; BORZACCONI, L.; MUXI, L. (eds.), Montevidéo, pp.169-184.

CHANG, D.; HUR, J.M.; CHUNG (1994). Digestion of municipal sludge by anaerobic sequencing batch reactor. Water Science and Technology, 35, No 12: pp. 161-170.

CUBAS, S.A.; FOREST, E.; RODRIGUES, J.A.D., RATUSZNEI, S.M.; ZAIAT, M. (2001). Influence of the liquid-phase mass transfer on the performance of a stirred anaerobic sequencing batch reactor containing immobilized biomass. In: Proceedings of the $9^{\text {th }}$ World Congress on Anaerobic Digestion, Antwerpen, Belgium, pp. 847-852. 
COSTERTON, J.W.; LEWANDOWSKI, Z.; CALDWELL, D.E.; KORBER, D.R.; LAPPIN-SCOTT, H.M. (1995). Microbial biofilms. Annuary Review of Microbiology, 49, pp.711-745.

DAGUE, R.R.; HABBEN, C.E.; PIDAPARTI, S.R. (1992). Initial studies on the anaerobic sequencing batch reactor. Water Science and Technology, 26: 2429-2432.

DILALlO, R., ALBERTSON, O.E. (1961). Volatile acids by direct titration. Journal Water Pollution Control Federation, 33 No 4, pp. 356-365.

DUGBA, P.N.; ZHANG, R. (1999). Treatment of dairy wastewater with two-stage anaerobic sequencing batch reactor systems - thermophilic versus mesophilic operations. Bioresource Technology, 68, 225-233.

DUGBA, P.N.; ZANG, R.; RUNSEY, T.R.; ELLIS, T.G. (1999). Computer simulation of the two-stage anaerobic sequencing batch reactor system for animal wastewater treatment. Transactions ASAE, 42: 471-477.

FORESTI, E. (1994). Fundamentos do processo de digestão anaeróbia. In: Anais do III Taller y Seminário Latino Americano- Tratamiento Anaeróbio de Águas Residuales. VIÑHAS, M.; SOUBES, M.; BORZACCONI, L.; MUXI, L. (eds.). Montevidéo, pp.97-123.

FORESTI, E.; FLORÊNCIO, L.; van HAANDEL, A.C.; ZAIAT, M.; CAVALCANTI, P.F.F. (1999). Fundamentos do tratamento anaeróbio. In: Tratamento de esgotos sanitários por processo anaeróbio e disposição controlada no solo. CAMPOS, J.R. (coord.). ABES, Rio de Janeiro, pp.29-52. 
FYNN, G.H.; WHITMORE, T.N. (1984). Retention of methanogens in colonized reticulades polyurethane foam biomass support particle. Biotechnology Letters, 6, pp.81-86.

GIJZEN, H.J.; SCHOENMAKERS, T.J.M.; CAERTELING, C.G.M.; VOGELS, G.D. (1988). Anaerobic degradation of papermill sludge in a two-phase digester conteining rumen microorganisms and colonized polyurethane foam. Biotechnology Letters, 10, pp.61-66.

GUIOT, S.R.; PAUSS, A.; COSTERTON, J.W. (1992). A structured model of the anaerobic granule consortium. Water Science and Technology, 25, pp.1-10.

HAMILTON, W.A. (1987). Biofilms: microbial interactions and metabolic activities. In Ecology of Microbial Communities, $41^{\text {st }}$ Symposium Society. Genetics Microbiology. Ed. FLETCHER, M.; GRAY, T.R.G.; JONES, J.G. Cambridge: Cambridge Univ. Press.

HARPER, S.R.; POHLAND, F.G. (1986). Recent developments in hydrogen management during anaerobic biological wastewater treatment. Biotechnology and Bioengineering, 28: 585-602.

HENZE, M.; HARREMÖES, P. (1983). Anaerobic treatment of wastewater in fixed film reactors. Water Science and Technology, 15, pp.1-101.

HIRL, R.J.; IRVINE, R.L. (1996). Reductive dechlorination of perchloroethylene (PCE) using anaerobic sequencing batch biofilm reactors (AnSBBR). In: $51^{\text {st }}$. Purdue Industrial Waste Conference Proceedings. Ann Arbor Press, Chelsea, pp.289-295. 
HOLLOPETER, J.A.; DAGUE, R.R. (1994). Anaerobic sequencing batch reactor treatment of landfill leachate. In: $49^{\text {st }}$. Purdue Industrial Waste Conference Proceedings. Ann Arbor Press, Chelsea, pp.277-284.

HUYSMAN, P.; van MEENEN, P.; van ASSCHE, P.; VERSTRAETE, W. (1983). Factors affecting the colonization of non porous and porous packing materials in model upflow methane reactors. Biotechnology Letters, 5, pp.643-648.

KATO, M.T.; ANDRADE NETO, C.O.; CHERNICHARO, C.A.L.; FORESTI, E.; CYBIS, L.F. (1999). In: Tratamento de esgotos sanitários por processo anaeróbio e disposição controlada no solo. CAMPOS, J.R. (coord.). ABES, Rio de Janeiro, pp.53-99.

LETTINGA, G. (1994). Anaerobic treatment of very low strength and cold industrial and domestic wastewaters. In: Anais do III Taller y Seminário Latino AmericanoTratamiento Anaeróbio de Águas Residuales. VIÑHAS, M.; SOUBES, M.; BORZACCONI, L.; MUXI, L. (eds.). Montevidéo, pp.113-126.

LETTINGA, G. (1995). Anaerobic digestion and wastewater treatment systems. Antonievan Leeuwenhoek, 67:3-28.

MASSÉ, D.I.; DROSTE, R.L.; KENNEDY, K.; PATNI, N.K.; MUNROE, J.A. (1997). Potential for the psychrophilic anaerobic treatment of swine manure using a sequencing batch reactor. Canadian Agricultural Engineeing, 39, pp.25-33.

NDON, U.J.; DAGUE, R.R. (1997). Ambient temperature treatment of low strength wastewater using anaerobic sequencing batch reactor. Biotechnology Letters, 19: 319-323. 
NG, W.J. (1989). A Sequencing Batch Reactor for Treating Piggery Wastewater. Biological Wastes, 28, pp. 39-51.

PODLECH, P.A.S.; LUNA, M.F.; JERKE, P.R.; SOUZA, O.; SOUZA NETO, C.A.C.; PASSOS, R.F.; BORZANI, W. (1991). Fermentação Semi-Contínua de Soro de Leite por Lactobacillus bulgaricus em Instalação Piloto. Revista do Instituto Cândido Tostes, 46: 26-33.

RATUSZNEI, S.M.; RODRIGUES, J.A.D.; CAMARGO, E.F.M.; ZAIAT, M.; BORZANI, W. (2000). Feasibility of a stirred anaerobic sequencing batch reactor containing immobilized biomass for wastewater treatment. Bioresource Technology, 75, $127-132$.

RATUSZNEI, S.M.; RODRIGUES, J.A.D.; CAMARGO, E.F.M.; ZAIAT, M.; BORZANI, W. (2001). Influence of agitation rate on the performance of a stirred anaerobic sequencing batch reactor containing immobilized biomass. Water Science and Technology, 44 No 4, pp.305-412.

REYES III, F.L.; DAGUE, R.R. (1995). Effects of initial seed concentration on the startup of anaerobic sequencing batch reactor. In: $50^{\text {th }}$. Purdue Industrial Waste Conference Proceedings. Ann Arbor Press: pp.449-459.

RIBEIRO, R. (2001). Influência do tipo de substrato na dinâmica de formação do biofilme em matrizes de espuma de poliuretano. Dissertação de Mestrado. Escola de Engenharia de São Carlos, Universidade de São Paulo. São Carlos.

RIPLEY, L.E.; BOYLE, W.C.; CONVERSE, J.C. (1986). Improved alkalimetric monitoring anaerobic digestion of high-strenght wastes. Journal of Water Pollution Control Federation, 58, pp.406-411. 
RODRIGUES, J.A.D.; RATUSZNEI, S.M.; ZAIAT, M. (2003). Fed-batch and batch operating mode analysis of a stirred anaerobic sequencing reactor with selfimmobilized biomass treating low-strength wastewater. Advanced in Environmental Research (submetido).

RUIZ, C.; TORRIJOS, M.; SOUSBIE, P.; LEBRATO MARTINES, J.; MOLETTA, R.; DELGENÈS, J.P. (2001). Treatment of winery wastewater by an anaerobic sequencing batch reactor (ASBR). In: Proceedings of $9^{\text {th }}$ World Congress on Anaerobic Digestion, Antuérpia, pp.347-353.

SCHMIDT, C.G.; DAGUE, R.R. (1993). Anaerobic sequencing batch reactor treatment of swine wastes at $20^{\circ} \mathrm{C}, 25^{\circ} \mathrm{C}$ and $35^{\circ} \mathrm{C}$. In: $50^{\text {th }}$ Purdue Industrial Waste Conference Proceedings. Ann Arbor Press. Chelsea, pp.541-549.

SPEECE, R.E. (1996). Anaerobic biotechnology for industrial wastewater treatment. Ed. Archae Press, Nashville, 394p.

SHIZAS, I.; BAGLEY, D.M. (2002). Improving anaerobic sequencing batch reactor performance by modifying operational parameters. Water Research, No 36, 363-367.

SUNG, S.; DAGUE, R.R. (1995). Laboratory studies on the anaerobic sequencing batch reactor. Water Environmental Research, 67, 294-301.

TORRES, P.(1992). Desempenho de um reator anaeróbio de manta de lodo (UASB) de bancada no tratamento de substrato sintético simulando esgotos sanitários. Dissertação de mestrado. Escola de Engenharia de São Carlos, Universidade de São Paulo, São Carlos, 174 p.

TIMUR, H.; ÖSTURK, I. (1999). Anaerobic sequencing batch reactor treatment of landfill leachate. Water Research, 33, pp.3225-3230. 
TUNDISI, J.G.; BARBOSA, F.A.R. (1995). Conservation of aquatic ecosystems: present status and perspectives. In: Limnology in Brasil. TUNDISI, J.G; BICUDO, C.E.M. e TUNDISI, T.M. (eds). Impresso por Academia Brasileira de Ciências e Sociedade Brasileira de Limnologia. 376p.

van HAANDELL, A.C.; LETTINGA, G. (1994). Tratamento anaeróbio de esgotos. Um manual para regiões de clima quente. UFPb, Campina Grande, 232p.

VARESCHE, M.B.; ZAIAT, M.; VIEIRA, L.G.T.; VAZOLLER, R.F., FOREST, E. (1997). Microbial colonization of polyurethane foam matrices in horizontal-flow anaerobic immobilized-sludge reactor. Applied Microbiology Biotechnology, 48: pp.534-538.

VAZOLLER, R.F.; MANFIO, G.P.; CANHOS, V.P. (1999). Diversidade do domínio Archae. In: Biodiversidade no Estado de São Paulo, Brasil. Volume 1: Microrganismos e vírus. CANHOS, V.P.; VAZOLLER, R.F. (eds.). FAPESP, São Paulo, pp.15-24.

VERRIER, D.; MORTIER, B.; ALBAGNAC, G. (1987). Initial adhesion of methanogenic bactéria to polymers. Biotechnology Letters, 9, pp.735-740.

WIRTZ R.A.; DAGUE, R.R. (1997). Laboratory studies on enhancement of granulation in the anaerobic sequencing batch reactor. Water Science and Technology, 36, pp.279-286.

YAN, J.Q.; LIAO, P.H.; LO, K.V. (1988). Methane Production from Cheese Whey. Biomass, 17: pp.185-202.

ZANG, T.; FANG, H.H.P. (2001). Quantification of extracellular polimeric substances in biofilms by confocal laser scaning microscopy. Biotechnology Letters 23:405-409. 
ZAIAT, M.; CABRAL, A.K.A.; FORESTI, E.; (1994). Horizontal-flow anaerobic immobilized sludge reactor for wastewater treatment: Conception and performance evaluation. Revista Brasileira de Engenharia- Caderno de Engenharia Química, 11, $33-42$.

ZAIAT, M.; RODRIGUES, J.A.D.; RATUSZNEI, S.M.; CAMARGO, E.F.M.; BORZANI, W. (2001). Anaerobic sequencing batch reactors for wastewater treatment: A developing technology. Applied Microbiology and Biotechnology, 55,: 29-35.

ZENDER, A.J.B.; INGVORSEN, K.; MARTI, T.(1982). Microbiology of methane bacteria. In: Proceedings of International Symposium on Anaerobic Digestion, Sept 1981, TRAVEMUNDE, F.R.G., ELSEVIER Biomedical Press, Amsterdam, The Netherlands, pp.45-68.

ZHANG, R.; YIN, Y.; SUNG, S.; DAGUE, R. (1996). Anaerobic treatment of swine waste by the anaerobic sequencing batch reactor. In: $51^{\text {st }}$ Purdue Industrial Waste Conference Proceedings. Ann Arbor Press: pp.315-321. 


\begin{abstract}
APÊNDICE I
PROJETO DO REATOR ANAERÓBIO OPERADO EM BATELADA SEQÜENCIAL
\end{abstract}

VISTAS E CORTES 


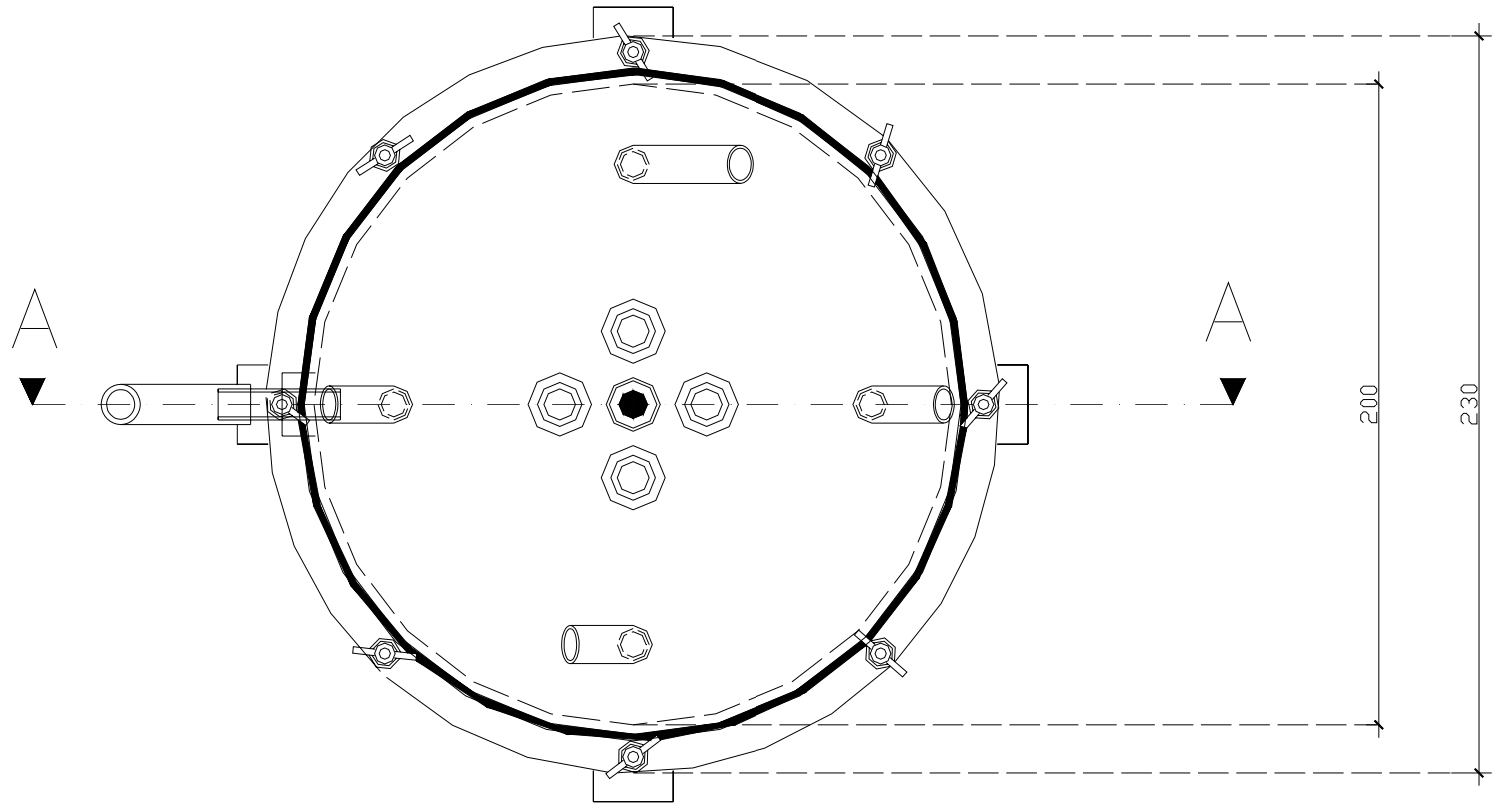

FIGURA I.1 - Vista superior do reator anaeróbio operado em batelada seqüencial. ESCALA 1:3 


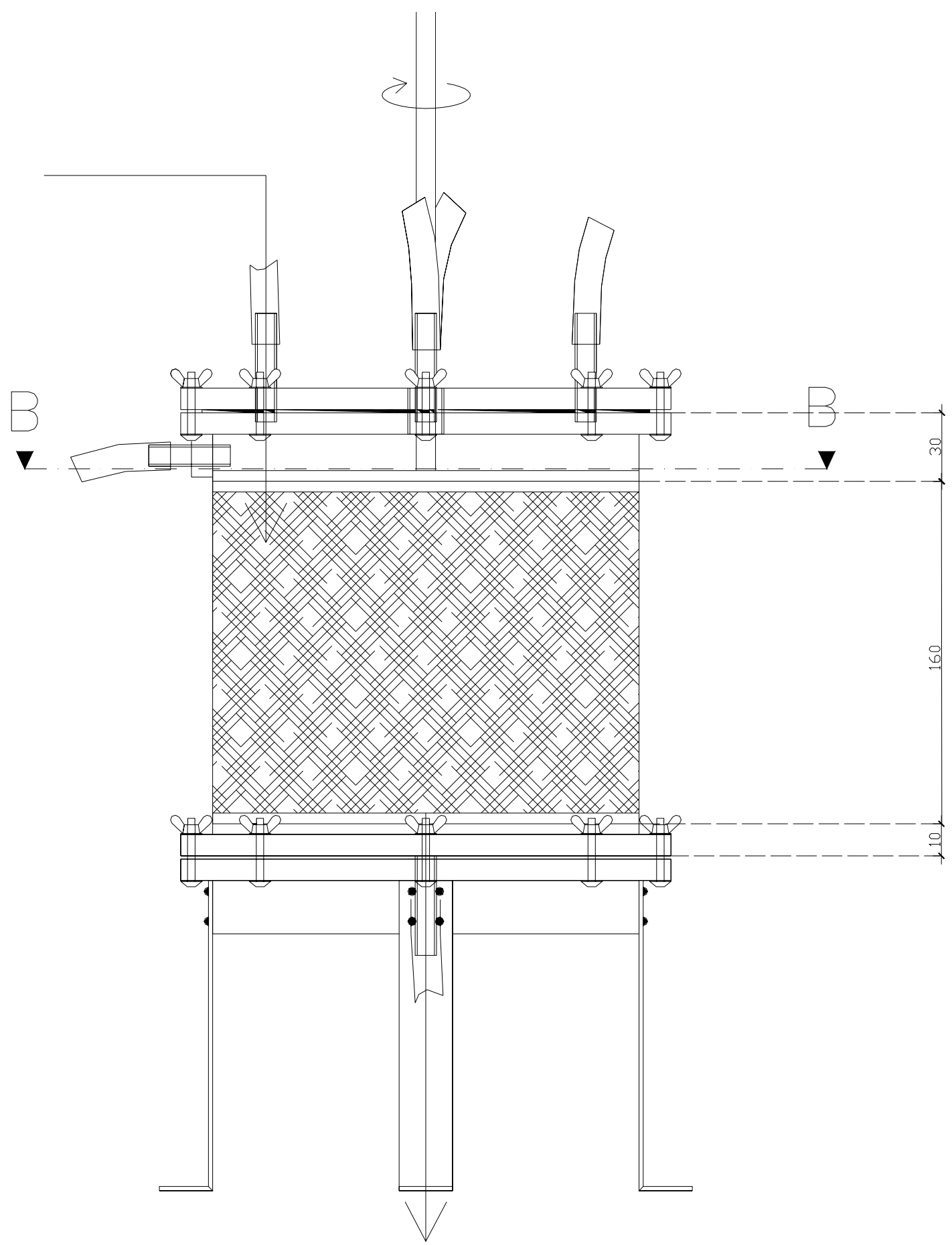

FIGURA I.2 - Vista frontal do reator anaeróbio operado em batelada seqüencial. ESCALA 1:3 


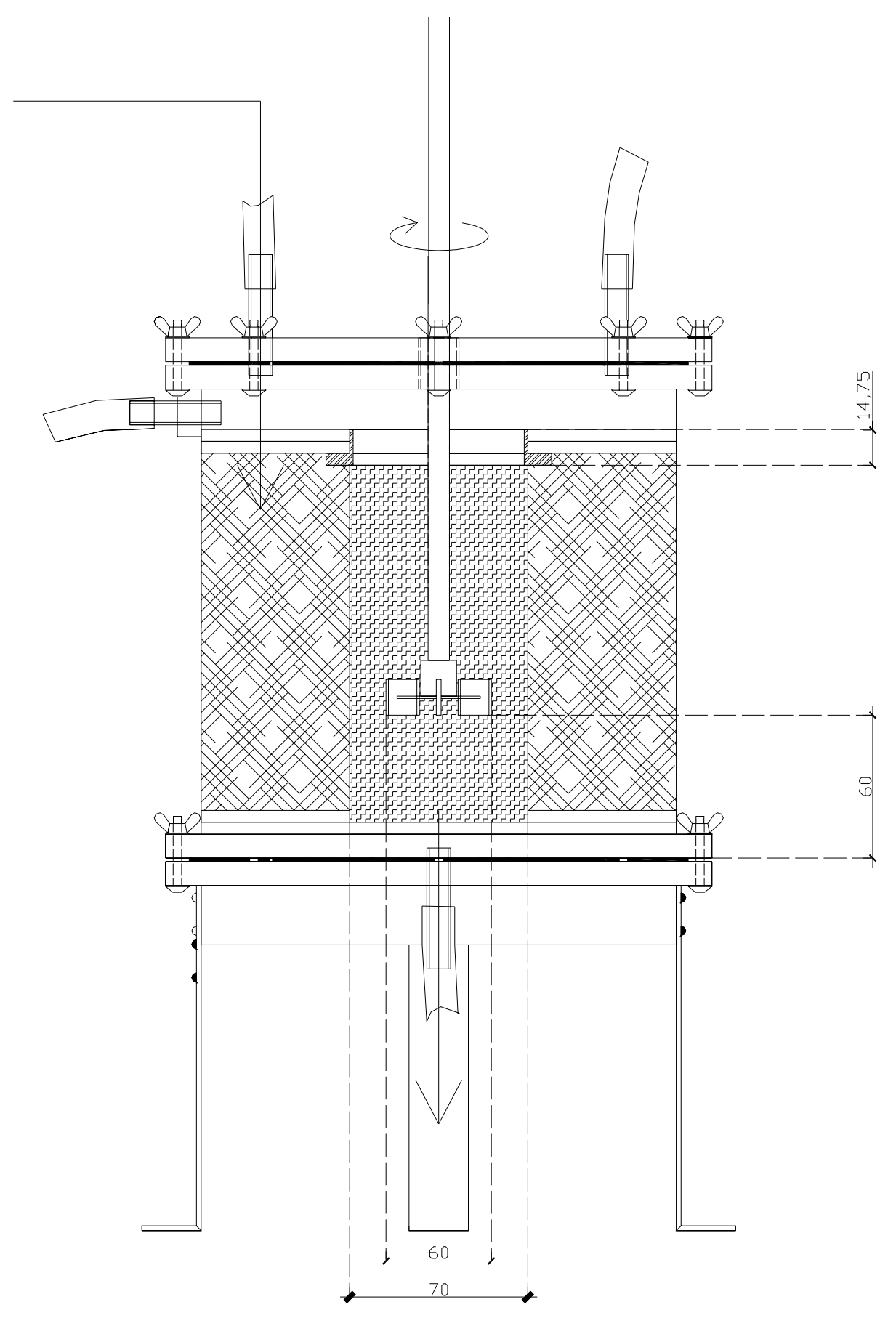

FIGURA I.3 - Reator anaeróbio operado em batelada seqüencial. Corte A

ESCALA 1:3 


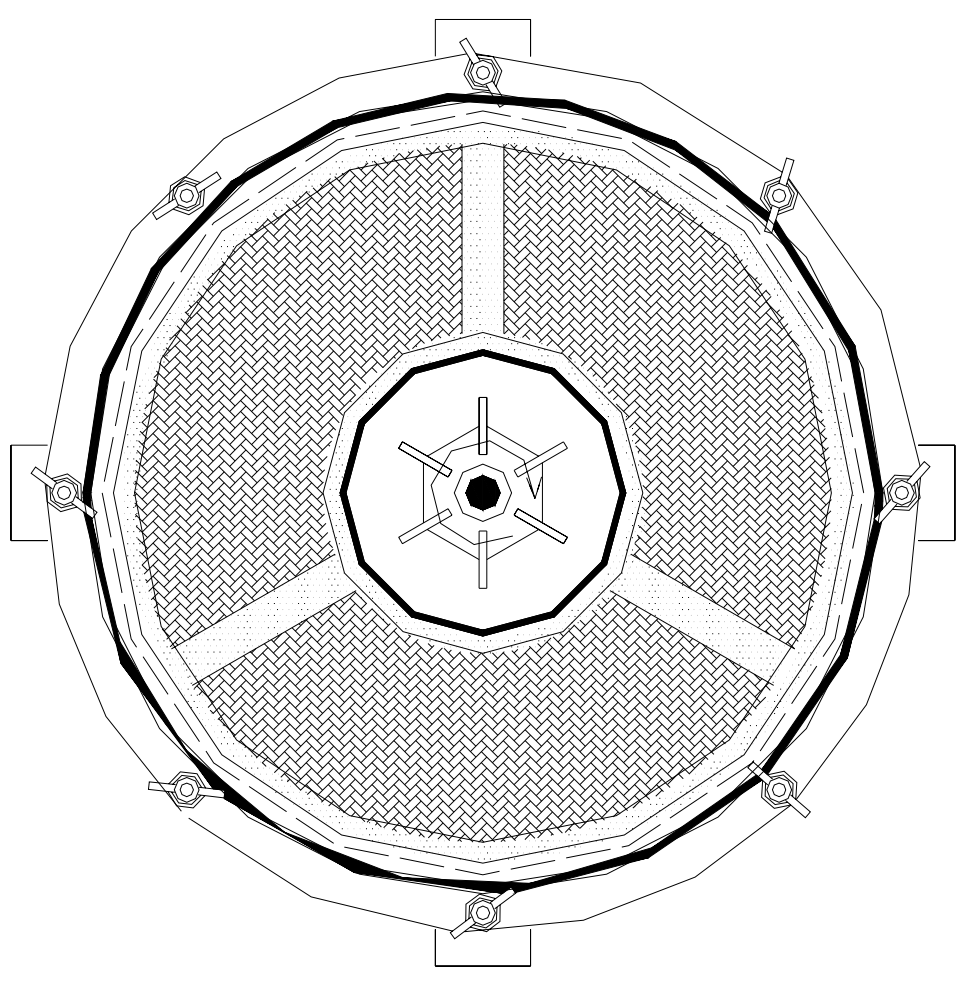

FIGURA I.4 - Reator anaeróbio operado em batelada seqüencial. Corte B ESCALA 1:3 


\section{APÊNDICE II}

\section{VARIÁVEIS MONITORADAS NO AFLUENTE DO REATOR}

(a) Operação com Alimentação de 500 mgDQO/L e Ciclos de 8 h.

TABELA II.1 - Concentração de substrato $\left(\mathrm{C}_{\mathrm{A}}\right), \mathrm{pH}$, alcalinidade parcial (AP), alcalinidade intermediária (AI), alcalinidade total (AT), relação entre as alcalinidades intermediária e total (AI/AP), alcalinidade a bicarbonato (AB) e concentração de ácidos voláteis totais (AVT) da água residuária na concentração de 500 mgDQO/L.

\begin{tabular}{ccccccccc}
\hline Meio & $\mathrm{C}_{\mathrm{A}}$ & $\mathrm{pH}$ & $\mathrm{AP}$ & $\mathrm{AI}$ & $\mathrm{AT}$ & $\mathrm{AI} / \mathrm{AP}$ & $\mathrm{AB}$ & $\mathrm{AVT}$ \\
\hline 1 & 502,2 & 7,46 & 123,2 & 35,7 & 158,9 & 0,29 & 135,3 & 33,3 \\
2 & 514,3 & 7,90 & 120,7 & 21,9 & 142,7 & 0,18 & 124,1 & 26,1 \\
4 & 457,1 & 7,43 & 118,5 & 34,9 & 153,3 & 0,29 & 133,1 & 28,6 \\
5 & 456,7 & 8,85 & 117,1 & 30,1 & 147,2 & 0,26 & 126,6 & 29,1 \\
6 & 450,2 & - & - & - & - & - & - & - \\
7 & - & 8,90 & 108,2 & 34,0 & 142,3 & 0,31 & 117,9 & 34,4 \\
8 & 466,4 & 7,95 & 126,9 & 24,8 & 151,6 & 0,20 & 132,2 & 27,4 \\
10 & 510,1 & - & - & - & - & - & - & - \\
11 & 519,2 & - & - & - & - & - & - & - \\
12 & 444,1 & - & - & - & - & - & - & - \\
13 & 472,7 & - & - & - & - & - & - & - \\
15 & 605,4 & 9,17 & 120,4 & 28,1 & 148,5 & 0,23 & 126,1 & 31,5 \\
16 & 471,9 & - & - & - & - & - & - & - \\
17 & 485,9 & - & - & - & - & - & - & - \\
18 & 469,8 & - & - & - & - & - & - & - \\
19 & 652,8 & - & - & - & - & - & - & - \\
20 & 434,5 & 9,19 & 120,8 & 35,5 & 156,2 & 0,29 & 135,2 & 29,6 \\
21 & 428,8 & 8,91 & 118,8 & 30,9 & 149,7 & 0,26 & 131,5 & 25,6 \\
22 & 487,4 & - & - & - & - & - & - & - \\
\hline
\end{tabular}

Continua 
TABELA II.1 - Continuação.

\begin{tabular}{ccccccccc}
\hline Meio & $\mathrm{C}_{\mathrm{A}}$ & $\mathrm{pH}$ & $\mathrm{AP}$ & $\mathrm{AI}$ & $\mathrm{AT}$ & $\mathrm{AI} / \mathrm{AP}$ & $\mathrm{AB}$ & $\mathrm{AVT}$ \\
\hline 24 & 545,6 & 7,16 & 101,6 & 42,8 & 144,3 & 0,42 & 116,3 & 39,5 \\
25 & 476,7 & - & - & - & - & - & - & - \\
26 & 477,0 & 8,17 & 120,3 & 21,9 & 142,2 & 0,18 & 115,6 & 37,3 \\
27 & 485,6 & 9,08 & 117,7 & 29,6 & 147,3 & 0,25 & 127,3 & 28,1 \\
28 & 535,6 & 8,80 & 123,3 & 24,9 & 148,2 & 0,20 & 127,6 & 29,0 \\
29 & 476,7 & - & - & - & - & - & - & - \\
32 & 489,4 & - & - & - & - & - & - & - \\
33 & 490,3 & - & - & - & - & - & - & - \\
34 & 473,1 & - & - & - & - & - & - & - \\
35 & - & 8,54 & 125,1 & 28,3 & 153,4 & 0,23 & 137,5 & 22,5 \\
\hline
\end{tabular}

Unidades:

$\mathrm{C}_{\mathrm{A}}=\mathrm{mgDQO} / \mathrm{L}$

$\mathrm{AP}, \mathrm{AI}, \mathrm{AT}$ e $\mathrm{AB}=\mathrm{mgCaCO}_{3} / \mathrm{L}$;

$\mathrm{AVT}=\operatorname{mgHAc} / \mathrm{L}$.

TABELA II.2 - Sólidos da água residuária na concentração de 500 mgDQO/L.

\begin{tabular}{ccccc}
\hline Meio & ST & SV & SST & SSV \\
\hline 4 & 1118 & 0 & 64 & 58 \\
6 & 1072 & 606 & 38 & 36 \\
11 & 1108 & 742 & 52 & 30 \\
15 & 1140 & 630 & 82 & 62 \\
17 & 1060 & 610 & - & - \\
19 & 1036 & 644 & 30 & 18 \\
29 & 1072 & 622 & 48 & 48 \\
33 & 1030 & 590 & 48 & 24 \\
35 & 1062 & 614 & 54 & 24 \\
\hline
\end{tabular}

Unidades:

$\mathrm{ST}, \mathrm{SV}, \mathrm{SST}$ e SSV $=\mathrm{mg} / \mathrm{L}$. 
(b) Operação com Alimentação de 1000 mgDQO/L e Ciclos de 8 h.

TABELA II.3 - Concentração de substrato $\left(\mathrm{C}_{\mathrm{A}}\right), \mathrm{pH}$, alcalinidade parcial (AP), alcalinidade intermediária (AI), alcalinidade total (AT), relação entre as alcalinidades intermediária e total (AI/AP), alcalinidade a bicarbonato $(\mathrm{AB})$ e concentração de ácidos voláteis totais (AVT) da água residuária na concentração de 1000 mgDQO/L.

\begin{tabular}{ccccccccc}
\hline Meio & $\mathrm{C}_{\mathrm{A}}$ & $\mathrm{pH}$ & $\mathrm{AP}$ & $\mathrm{AI}$ & $\mathrm{AT}$ & $\mathrm{AI} / \mathrm{AP}$ & $\mathrm{AB}$ & $\mathrm{AVT}$ \\
\hline 1 & 934,6 & 7,30 & 205,6 & 61,4 & 267,0 & 0,30 & 230,0 & 52,2 \\
2 & 1001,2 & - & - & - & - & - & - & - \\
3 & 981,7 & 7,37 & 206,3 & 59,3 & 265,6 & 0,29 & 233,7 & 44,9 \\
4 & 928,4 & - & - & - & - & - & - & - \\
5 & 928,2 & - & - & - & - & - & - & - \\
6 & 937,4 & - & - & - & - & - & - & - \\
7 & 1016,2 & 7,33 & 206,6 & 57,6 & 264,2 & 0,28 & 235,8 & 40,0 \\
8 & 953,4 & - & - & - & - & - & - & - \\
9 & 975,0 & 8,74 & 209,4 & 54,1 & 263,5 & 0,26 & 235,4 & 39,5 \\
10 & 958,8 & - & - & - & - & - & - & - \\
11 & 960,0 & - & - & - & - & - & - & - \\
12 & 994,0 & - & - & - & - & - & - & - \\
13 & 997,2 & - & - & - & - & - & - & - \\
14 & 895,0 & - & - & - & - & - & - & - \\
15 & 883,3 & - & - & - & - & - & - & - \\
16 & 874,6 & - & - & - & - & - & - & - \\
17 & 828,1 & - & - & - & - & - & - & - \\
18 & 966,0 & 8,88 & 212,9 & 52,4 & 265,2 & 0,25 & 227,1 & 53,7 \\
19 & 1003,4 & 8,96 & 209,1 & 52,0 & 261,1 & 0,25 & 230,4 & 43,2 \\
20 & 999,6 & - & - & - & - & - & - & - \\
21 & 926,4 & 7,12 & 185,7 & 58,6 & 244,3 & 0,32 & 206,0 & 53,9 \\
22 & 905,8 & 8,90 & 212,9 & 52,0 & 264,9 & 0,24 & 230,9 & 47,9 \\
23 & 954,8 & 8,60 & 217,8 & 47,1 & 264,9 & 0,22 & 231,1 & 47,6 \\
24 & 943,0 & 8,48 & 217,1 & 60,1 & 277,2 & 0,28 & 244,7 & 45,8 \\
25 & 1014,6 & - & - & - & - & - & - & - \\
26 & 953,4 & - & - & - & - & - & - & - \\
27 & 840,0 & 8,50 & 220,1 & 55,2 & 273,3 & 0,23 & 243,6 & 44,6 \\
\hline & & & & & & & Continua
\end{tabular}


TABELA II.3 - Continuação

\begin{tabular}{ccccccccc}
\hline Meio & $\mathrm{C}_{\mathrm{A}}$ & $\mathrm{pH}$ & $\mathrm{AP}$ & $\mathrm{AI}$ & $\mathrm{AT}$ & $\mathrm{AI} / \mathrm{AP}$ & $\mathrm{AB}$ & $\mathrm{AVT}$ \\
\hline 29 & 939,8 & - & - & - & - & - & - & - \\
30 & 958,2 & - & - & - & - & - & - & - \\
31 & 1372,4 & - & - & - & - & - & - & - \\
32 & 943,6 & - & - & - & - & - & - & - \\
33 & 1028,8 & - & - & - & - & - & - & - \\
34 & 954,6 & - & - & - & - & - & - & - \\
35 & 918,0 & - & - & - & - & - & - & - \\
36 & 938,0 & - & - & - & - & - & - & - \\
37 & 1023,0 & - & - & - & - & - & - & - \\
38 & 956,8 & - & - & - & - & - & - \\
\hline Unidades: & & & & & & \\
$\mathrm{C}_{\mathrm{A}}=\mathrm{mgDQO} / \mathrm{L} ;$ \\
$\mathrm{AP}, \mathrm{AI}, \mathrm{AT} \mathrm{e} \mathrm{AB}=\mathrm{mgCaCO} / \mathrm{L} ;$
\end{tabular}

TABELA II.4 - Sólidos da água residuária na concentração de 1000 mgDQO/L.

\begin{tabular}{ccccc}
\hline Meio & ST & SVT & SST & SSV \\
\hline 3 & 1246 & 1002 & 42 & 42 \\
5 & 1328 & 698 & 52 & 46 \\
9 & 1936 & 1162 & 58 & 36 \\
11 & 1090 & 350 & 60 & 42 \\
14 & 1782 & 1004 & 50 & 50 \\
17 & 1780 & 984 & - & - \\
18 & 2058 & 1102 & 70 & 34 \\
21 & 1934 & 1110 & 80 & 50 \\
22 & 2108 & 1250 & 86 & 30 \\
26 & 1984 & 1148 & 62 & 48 \\
41 & 1644 & 714 & 40 & 36 \\
\hline \multicolumn{5}{l}{ Unidades: } \\
\multicolumn{5}{l}{ ST, SV, SST e SSV $=\mathrm{mg} / \mathrm{L}}$.
\end{tabular}


(c) Operação com Alimentação de 2000 mgDQO/L e Ciclos de 8 h.

TABELA II.5 - Concentração de substrato $\left(\mathrm{C}_{\mathrm{A}}\right), \mathrm{pH}$, alcalinidade parcial (AP), alcalinidade intermediária (AI), alcalinidade total (AT), relação entre as alcalinidades intermediária e total (AI/AP), alcalinidade a bicarbonato $(\mathrm{AB})$ e concentração de ácidos voláteis totais (AVT) da água residuária na concentração de 2000 mgDQO/L.

\begin{tabular}{ccccccccc}
\hline Meio & $\mathrm{C}_{\mathrm{A}}$ & $\mathrm{pH}$ & $\mathrm{AP}$ & $\mathrm{AI}$ & $\mathrm{AT}$ & $\mathrm{AI} / \mathrm{AP}$ & $\mathrm{AB}$ & $\mathrm{AVT}$ \\
\hline 1 & 1885,6 & 7,94 & 438,7 & 116,5 & 555,2 & 0,27 & 497,6 & 81,1 \\
2 & 2039,2 & - & - & - & - & - & - & - \\
3 & 1664,4 & 8,32 & 444,0 & 121,9 & 565,9 & 0,27 & 505,0 & 85,8 \\
4 & 1960,8 & 8,70 & 450,1 & 116,5 & 566,6 & 0,26 & 506,1 & 85,3 \\
5 & 1964,8 & - & - & - & - & - & - & - \\
6 & 1529,2 & - & - & - & - & - & - & - \\
7 & - & 8,80 & 447,9 & 116,5 & 564,5 & 0,26 & 503,6 & 85,8 \\
8 & 1802,8 & - & - & - & - & - & - & - \\
9 & 1774,4 & - & - & - & - & - & - & - \\
10 & 1785,6 & 8,78 & 461,7 & 119,9 & 581,6 & 0,26 & 512,5 & 97,3 \\
11 & 1726,8 & 8,42 & 452,7 & 122,9 & 575,6 & 0,27 & 519,0 & 79,8 \\
12 & 1785,2 & 8,68 & 461,7 & 122,9 & 584,6 & 0,27 & 530,5 & 76,2 \\
\hline
\end{tabular}

Unidades:

$\mathrm{C}_{\mathrm{A}}=\operatorname{mgDQO} / \mathrm{L}$;

$\mathrm{AP}, \mathrm{AI}, \mathrm{AT}$ e $\mathrm{AB}=\mathrm{mgCaCO}_{3} / \mathrm{L}$;

$\mathrm{AVT}=\operatorname{mgHAc} / \mathrm{L}$.

TABELA II.6 - Sólidos da água residuária na concentração de 2000 mgDQO/L.

\begin{tabular}{ccccc}
\hline Meio & ST & SV & SST & SSV \\
\hline 2 & 3204 & 1464 & 62 & 34 \\
5 & 3064 & 1402 & - & - \\
7 & 2968 & 1498 & 38 & 24 \\
9 & 3460 & 1522 & 94 & 66 \\
10 & 3284 & 1538 & 86 & 62 \\
\hline \multicolumn{2}{l}{ Unidades: }
\end{tabular}

ST, SV, SST e SSV $=\mathrm{mg} / \mathrm{L}$. 
(d) Operação com Alimentação de 2000 mgDQO/L e Ciclos de 12 h.

TABELA II.7 - Concentração de substrato $\left(\mathrm{C}_{\mathrm{A}}\right), \mathrm{pH}$, alcalinidade parcial (AP), alcalinidade intermediária (AI), alcalinidade total (AT), relação entre as alcalinidades intermediária e total (AI/AP), alcalinidade a bicarbonato $(\mathrm{AB})$ e concentração de ácidos voláteis totais (AVT) da água residuária na concentração de 2000 mgDQO/L.

\begin{tabular}{ccccccccc}
\hline Meio & $\mathrm{C}_{\mathrm{A}}$ & $\mathrm{pH}$ & $\mathrm{AP}$ & $\mathrm{AI}$ & $\mathrm{AT}$ & $\mathrm{AI} / \mathrm{AP}$ & $\mathrm{AB}$ & $\mathrm{AVT}$ \\
\hline 3 & 1959,2 & - & - & - & - & - & - & - \\
4 & 1890,0 & 8,74 & 420,6 & 110,7 & 531,3 & 0,26 & 485,6 & 64,4 \\
5 & 1840,2 & 8,75 & 414,3 & 110,7 & 525,0 & 0,27 & 472,5 & 73,9 \\
6 & 1769,2 & - & - & - & - & - & - & - \\
7 & 1745,2 & - & - & - & - & - & - & - \\
8 & 1757,4 & - & - & - & - & - & - & - \\
9 & 1535,5 & - & - & - & - & - & - & - \\
11 & 1780,4 & 8,85 & 365,8 & 101,0 & 466,7 & 0,28 & 418,7 & 67,6 \\
12 & 1936,4 & 8,92 & 371,2 & 98,3 & 469,5 & 0,26 & 410,9 & 82,5 \\
13 & 1727,2 & 8,73 & 408,9 & 132,1 & 540,9 & 0,32 & 476,2 & 91,2 \\
14 & - & 8,61 & 426,1 & 127,1 & 553,2 & 0,30 & 504,0 & 69,2 \\
15 & 1958,8 & - & - & - & - & - & - & - \\
17 & 1832,8 & - & - & - & - & - & - & - \\
18 & 1772,8 & - & - & - & - & - & - & - \\
19 & 1790,4 & - & - & - & - & - & - & - \\
20 & 1828,8 & 8,89 & 424,6 & 116,6 & 541,2 & 0,27 & 486,6 & 76,9 \\
\hline
\end{tabular}

Unidades:

$\mathrm{C}_{\mathrm{A}}=\operatorname{mgDQO} / \mathrm{L}$;

$\mathrm{AP}, \mathrm{AI}, \mathrm{AT}$ e $\mathrm{AB}=\mathrm{mgCaCO}_{3} / \mathrm{L}$;

$\mathrm{AVT}=\mathrm{mgHAc} / \mathrm{L}$. 
TABELA II.8 - Sólidos da água residuária na concentração de 2000 mgDQO/L.

\begin{tabular}{ccccc}
\hline Meio & ST & SV & SST & SSV \\
\hline 4 & 3210 & 1464 & 118 & 94 \\
5 & 3214 & 1542 & 74 & 58 \\
11 & 3144 & 1152 & - & - \\
13 & 3016 & 1362 & 54 & 34 \\
15 & 3316 & 1470 & 136 & 70 \\
18 & 3420 & 1544 & 150 & 78 \\
20 & 3306 & 1506 & 106 & 56 \\
\hline
\end{tabular}

Unidades:

$\mathrm{ST}, \mathrm{SV}, \mathrm{SST}$ e SSV $=\mathrm{mg} / \mathrm{L}$. 
(e) Operação com Alimentação de $1500 \mathrm{mgDQO} / \mathrm{L}$ e Ciclos de 12 h.

TABELA II.9 - Concentração de substrato $\left(\mathrm{C}_{\mathrm{A}}\right), \mathrm{pH}$, alcalinidade parcial (AP), alcalinidade intermediária (AI), alcalinidade total (AT), relação entre as alcalinidades intermediária e total (AI/AP), alcalinidade a bicarbonato $(\mathrm{AB})$ e concentração de ácidos voláteis totais (AVT) da água residuária na concentração de 1500 mgDQO/L.

\begin{tabular}{ccccccccc}
\hline Meio & $\mathrm{C}_{\mathrm{A}}$ & $\mathrm{pH}$ & $\mathrm{AP}$ & $\mathrm{AI}$ & $\mathrm{AT}$ & $\mathrm{AI} / \mathrm{AP}$ & $\mathrm{AB}$ & $\mathrm{AVT}$ \\
\hline 1 & 1472,5 & 9,05 & 340,4 & 79,0 & 419,5 & 0,23 & 361,4 & 81,7 \\
2 & 1372,6 & - & - & - & - & - & - & - \\
3 & 1306,0 & 8,60 & 325,2 & 97,3 & 422,5 & 0,30 & 381,1 & 58,4 \\
4 & 1428,0 & 8,75 & 325,2 & 54,7 & 379,9 & 0,17 & 325,5 & 76,7 \\
5 & 1464,8 & 8,98 & 331,3 & 88,1 & 419,5 & 0,27 & 374,9 & 62,7 \\
6 & 1274,8 & - & - & - & - & - & - & - \\
7 & 1417,4 & 8,80 & 328,3 & 82,1 & 410,3 & 0,25 & 359,2 & 72,1 \\
8 & 1431,4 & 8,71 & 340,3 & 89,6 & 429,8 & 0,26 & 388,2 & 58,7 \\
9 & 1342,4 & 8,34 & 331,3 & 92,5 & 423,9 & 0,28 & 382,2 & 58,7 \\
10 & 1291,4 & 8,70 & 340,8 & 83,7 & 424,5 & 0,25 & 377,3 & 66,4 \\
11 & 1247,8 & - & - & - & - & - & - & - \\
12 & 1241,2 & - & - & - & - & - & - & - \\
13 & 1415,6 & - & - & - & - & - & - & - \\
14 & 1331,0 & - & - & - & - & - & - & - \\
15 & 1380,0 & 8,73 & 372,3 & 82,6 & 455,0 & 0,22 & 404,7 & 70,8 \\
16 & 1390,4 & - & - & - & - & - & - & - \\
17 & 1521,8 & 8,54 & 362,4 & 85,1 & 447,5 & 0,23 & 401,0 & 65,6 \\
18 & 1567,0 & - & - & - & - & - & - & - \\
20 & 1671,8 & 9,10 & 349,4 & 82,8 & 432,3 & 0,24 & 375,3 & 80,2 \\
\hline
\end{tabular}

Unidades:

$\mathrm{C}_{\mathrm{A}}=\mathrm{mgDQO} / \mathrm{L}$;

$\mathrm{AP}, \mathrm{AI}, \mathrm{AT}$ e $\mathrm{AB}=\mathrm{mgCaCO}_{3} / \mathrm{L}$;

$\mathrm{AVT}=\mathrm{mgHAc} / \mathrm{L}$. 
TABELA II.10 - Sólidos da água residuária na concentração de 1500 mgDQO/L.

\begin{tabular}{ccccc}
\hline Meio & ST & SV & SST & SSV \\
\hline 3 & 2320 & 1024 & 260 & 68 \\
7 & 2438 & 1140 & 62 & 42 \\
8 & 2508 & 1254 & 70 & 32 \\
12 & 2276 & 1210 & 170 & 148 \\
16 & 2632 & 1110 & 120 & 70 \\
\hline
\end{tabular}

Unidades:

$\mathrm{ST}, \mathrm{SV}, \mathrm{SST}$ e SSV $=\mathrm{mg} / \mathrm{L}$. 
(f) Operação com Alimentação de 1000 mgDQO/L e Ciclos de 12 h.

TABELA II.11 - Concentração de substrato $\left(\mathrm{C}_{\mathrm{A}}\right), \mathrm{pH}$, alcalinidade parcial (AP), alcalinidade intermediária (AI), alcalinidade total (AT), relação entre as alcalinidades intermediária e total (AI/AP), alcalinidade a bicarbonato $(\mathrm{AB})$ e concentração de ácidos voláteis totais (AVT) da água residuária na concentração de 1000 mgDQO/L.

\begin{tabular}{ccccccccc}
\hline Meio & $\mathrm{C}_{\mathrm{A}}$ & $\mathrm{pH}$ & $\mathrm{AP}$ & $\mathrm{AI}$ & $\mathrm{AT}$ & $\mathrm{AI} / \mathrm{AP}$ & $\mathrm{AB}$ & $\mathrm{AVT}$ \\
\hline 1 & 822,7 & 8,84 & 187,6 & 51,1 & 238,7 & 0,27 & 206,4 & 45,5 \\
2 & 910,0 & - & - & - & - & - & - & - \\
3 & 907,6 & 8,52 & 224,0 & 62,0 & 286,0 & 0,28 & 243,2 & 60,3 \\
4 & 1004,8 & - & - & - & - & - & - & - \\
5 & 1027,8 & 8,67 & 241,5 & 47,4 & 288,9 & 0,20 & 254,3 & 48,7 \\
6 & 1085,2 & - & - & - & - & - & - & - \\
7 & 1014,4 & - & - & - & - & - & - & - \\
8 & 1030,6 & 8,88 & 218,2 & 70,1 & 288,4 & 0,32 & 253,6 & 48,9 \\
10 & 976,4 & 8,53 & 230,5 & 60,7 & 291,2 & 0,26 & 243,1 & 67,7 \\
11 & 955,4 & - & - & - & - & - & - & - \\
12 & 911,2 & 8,85 & 235,5 & 53,9 & 289,4 & 0,23 & 248,5 & 57,7 \\
13 & 1137,4 & 8,61 & 231,3 & 76,7 & 308,0 & 0,33 & 276,0 & 45,1 \\
14 & 1092,2 & - & - & - & - & - & - & - \\
15 & 947,4 & - & - & - & - & - & - & - \\
16 & 1098,6 & 8,77 & 281,4 & 46,9 & 328,3 & 0,17 & 293,2 & 49,5 \\
17 & 944,0 & - & - & - & - & - & - & - \\
18 & 1028,0 & - & - & - & - & - & - & - \\
19 & 967,4 & - & - & - & - & - & - & - \\
20 & 981,6 & 8,69 & 225,9 & 56,0 & 281,9 & 0,25 & 244,2 & 53,1 \\
\hline
\end{tabular}

Unidades:

$\mathrm{C}_{\mathrm{A}}=\mathrm{mgDQO} / \mathrm{L}$;

$\mathrm{AP}, \mathrm{AI}, \mathrm{AT}$ e $\mathrm{AB}=\mathrm{mgCaCO}_{3} / \mathrm{L}$;

$\mathrm{AVT}=\mathrm{mgHAc} / \mathrm{L}$. 
TABELA II.12 - Sólidos da água residuária na concentração de 1000 mgDQO/L.

\begin{tabular}{ccccc}
\hline Meio & ST & SV & SST & SSV \\
\hline 1 & 1396 & 486 & 40 & 18 \\
2 & 1736 & 858 & 64 & 64 \\
3 & 1848 & 936 & - & 90 \\
5 & 1656 & 770 & 44 & 26 \\
8 & 1734 & 826 & 66 & 74 \\
11 & 1816 & 804 & 78 & 28 \\
13 & 1194 & 276 & - & 94 \\
14 & 1292 & 968 & - & - \\
17 & 1128 & 812 & - & - \\
19 & 1828 & 898 & - & - \\
\hline
\end{tabular}

Unidades:

$\mathrm{ST}, \mathrm{SV}, \mathrm{SST}$ e SSV $=\mathrm{mg} / \mathrm{L}$. 


\section{APÊNDICE III}

\section{VARIÁVEIS MONITORADAS NO EFLUENTE DO REATOR}

(a) Operação com Alimentação de 500 mgDQO/L e Ciclos de 8 h.

TABELA III.1 - Concentração de substrato filtrado e não filtrado( $\mathrm{C}_{\mathrm{EF}}$ e $\left.\mathrm{C}_{\mathrm{ET}}\right)$, remoção de matéria orgânica filtrada e não filtrada $\left(\varepsilon_{\mathrm{EF}}\right.$ e $\left.\varepsilon_{\mathrm{ET}}\right), \mathrm{pH}$, alcalinidade parcial (AP), alcalinidade intermediária (AI), alcalinidade total (AT), relação entre as alcalinidades intermediária e parcial (AI/AP), alcalinidade a bicarbonato $(\mathrm{AB})$ e concentração de ácidos voláteis totais (AVT) do efluente para condição de operação com batelada de $8 \mathrm{~h}$ e alimentação de $500 \mathrm{mgDQO} / \mathrm{L}$.

\begin{tabular}{cccccccccccc}
\hline Dias & $\mathrm{C}_{\mathrm{EF}}$ & $\varepsilon_{\mathrm{EF}}$ & $\mathrm{C}_{\mathrm{ET}}$ & $\varepsilon_{\mathrm{ET}}$ & $\mathrm{pH}$ & $\mathrm{AP}$ & $\mathrm{AI}$ & $\mathrm{AT}$ & $\mathrm{AI} / \mathrm{AP}$ & $\mathrm{AB}$ & $\mathrm{AVT}$ \\
\hline 3 & 112,5 & 77,20 & 118,6 & 75,96 & - & - & - & - & - & - & - \\
4 & 119,8 & 75,72 & 135,9 & 72,46 & 7,32 & 217,3 & 40,0 & 257,3 & 0,18 & 243,9 & 18,8 \\
5 & 90,7 & 81,62 & 102,6 & 67,04 & - & - & - & - & - & - & - \\
6 & 108,5 & 78,01 & 119,1 & 75,86 & 7,31 & 203,4 & 37,1 & 240,5 & 0,18 & 225,6 & 20,9 \\
7 & - & - & - & - & 7,61 & 192,5 & 39,4 & 231,9 & 0,20 & 219,2 & 17,9 \\
10 & 155,1 & 68,57 & 175,0 & 64,53 & 6,85 & 184,5 & 49,1 & 233,6 & 0,27 & 210,6 & 32,4 \\
11 & 98,9 & 79,96 & 116,2 & 76,45 & - & - & - & - & - & - & - \\
13 & 82,8 & 83,22 & 107,6 & 78,19 & 7,11 & 207,2 & 33,7 & 240,9 & 0,16 & 227,1 & 19,4 \\
14 & 80,1 & 83,77 & 105,6 & 78,60 & - & - & - & - & - & - & - \\
17 & 77,9 & 84,21 & 93,6 & 81,03 & - & - & - & - & - & - & - \\
18 & 79,2 & 83,95 & 107,4 & 78,23 & - & - & - & - & - & - & - \\
19 & 55,9 & 88,67 & 88,7 & 82,02 & 7,19 & 199,3 & 36,6 & 235,9 & 0,18 & 222,0 & 19,6 \\
20 & 81,2 & 83,54 & 101,0 & 79,53 & - & - & - & - & - & - & - \\
21 & 74,2 & 84,96 & 102,8 & 79,16 & 7,55 & 179,1 & 47,4 & 226,5 & 0,26 & 214,5 & 16,9 \\
24 & 92,6 & 81,23 & 94,6 & 80,83 & - & - & - & - & - & - & - \\
25 & 92,3 & 81,29 & 93,3 & 81,09 & - & - & - & - & - & - & - \\
\hline
\end{tabular}


TABELA III.1 - Continuação.

\begin{tabular}{|c|c|c|c|c|c|c|c|c|c|c|c|}
\hline Dias & $\mathrm{C}_{\mathrm{EF}}$ & $\varepsilon_{\mathrm{EF}}$ & $\mathrm{C}_{\mathrm{ET}}$ & $\varepsilon_{\mathrm{ET}}$ & $\mathrm{pH}$ & $\mathrm{AP}$ & $\overline{\mathrm{AI}}$ & AT & $\mathrm{AI} / \mathrm{AP}$ & $\mathrm{AB}$ & AVT \\
\hline 26 & 73,6 & 85,08 & 76,3 & 84,54 & 7,52 & 222,6 & 37,4 & 260,0 & 0,17 & 246,9 & 18,4 \\
\hline 27 & 67,3 & 86,36 & 84,4 & 82,89 & - & - & - & - & - & - & - \\
\hline 28 & 62,3 & 87,37 & 65,9 & 86,64 & 7,52 & 195,6 & 49,3 & 244,9 & 0,25 & 232,1 & 18,2 \\
\hline 31 & 54,5 & 88,95 & 63,9 & 87,05 & 7,64 & 203,6 & 40,8 & 244,5 & 0,20 & 229,1 & 21,7 \\
\hline 32 & 31,7 & 93,58 & 46,8 & 90,51 & - & - & - & - & - & - & - \\
\hline 33 & 55,3 & 88,79 & 60,0 & 87,84 & 7,58 & 202,2 & 40,6 & 242,8 & 0,20 & 229,1 & 19,2 \\
\hline 34 & 44,2 & 91,04 & 53,8 & 89,10 & - & - & - & - & - & - & - \\
\hline 35 & 48,7 & 90,13 & 63,2 & 87,19 & - & - & - & - & - & - & - \\
\hline 38 & 67,0 & 86,42 & 82,8 & 83,22 & - & - & - & - & - & - & - \\
\hline 39 & 74,0 & 85,00 & 92,6 & 81,23 & 7,51 & 196,8 & 43,1 & 240,0 & 0,22 & 226,4 & 19,1 \\
\hline 40 & 79,3 & 83,93 & 97,4 & 80,26 & - & - & - & - & - & - & - \\
\hline 42 & 62,6 & 87,43 & 72,5 & 85,31 & - & - & - & - & - & - & - \\
\hline 45 & 67,3 & 86,36 & 83,8 & 83,02 & 7,46 & 203,1 & 44,0 & 247,1 & 0,22 & 232,7 & 20,4 \\
\hline 46 & 65,4 & 86,75 & 78,4 & 84,03 & - & - & - & - & - & - & - \\
\hline 47 & 61,6 & 87,52 & 67,0 & 86,42 & - & - & - & - & - & - & - \\
\hline \multicolumn{12}{|c|}{ Unidades: } \\
\hline \multicolumn{12}{|c|}{$\mathrm{C}_{\mathrm{EF}}$ e $\mathrm{C}_{\mathrm{ET}}=\mathrm{mgDQO} / \mathrm{L}$} \\
\hline \multicolumn{12}{|c|}{$\varepsilon_{\mathrm{EF}}$ e $\varepsilon_{\mathrm{EF}}=\%$} \\
\hline \multicolumn{12}{|c|}{$\mathrm{AP}, \mathrm{AI}, \mathrm{AT}$ e $\mathrm{AB}=\mathrm{mgCaCO}_{3} / \mathrm{L}$} \\
\hline
\end{tabular}

TABELA III.2 - Sólidos efluentes para condição de operação com batelada de $8 \mathrm{~h}$ e alimentação de 500 mgDQO/L.

\begin{tabular}{ccccc}
\hline Dias & ST & SVT & SST & SSV \\
\hline 4 & 832 & 300 & 38 & 22 \\
13 & 660 & 334 & 40 & 40 \\
18 & 682 & 116 & 46 & 26 \\
25 & 648 & 230 & 28 & 28 \\
40 & 730 & 306 & 14 & 4 \\
46 & 532 & 268 & 26 & 2 \\
48 & 572 & 284 & 40 & 36 \\
\hline
\end{tabular}

Unidades:

ST, SV, SST e SSV = mg/L. 


\section{(b) Operação com Alimentação de $1000 \mathrm{mgDQO} / \mathrm{L}$ e Ciclos de 8 h}

TABELA III.3 - Concentração de substrato filtrado e não filtrado( $\mathrm{C}_{\mathrm{EF}}$ e $\left.\mathrm{C}_{\mathrm{ET}}\right)$, remoção de matéria orgânica filtrada e não filtrada $\left(\varepsilon_{\mathrm{EF}}\right.$ e $\left.\varepsilon_{\mathrm{ET}}\right), \mathrm{pH}$, alcalinidade parcial (AP), alcalinidade intermediária (AI), alcalinidade total (AT), relação entre as alcalinidades intermediária e parcial (AI/AP), alcalinidade a bicarbonato (AB) e concentração de ácidos voláteis totais (AVT) do efluente para condição de operação com batelada de $8 \mathrm{~h}$ e alimentação de $500 \mathrm{mgDQO} / \mathrm{L}$.

\begin{tabular}{cccccccccccc}
\hline Dias & $\mathrm{C}_{\mathrm{EF}}$ & $\varepsilon_{\mathrm{EF}}$ & $\mathrm{C}_{\mathrm{ET}}$ & $\varepsilon_{\mathrm{ET}}$ & $\mathrm{pH}$ & $\mathrm{AP}$ & $\mathrm{AI}$ & $\mathrm{AT}$ & $\mathrm{AI} / \mathrm{AP}$ & $\mathrm{AB}$ & $\mathrm{AVT}$ \\
\hline 3 & 184,8 & 80,79 & 199,1 & 79,30 & 7,26 & 310,6 & 97,7 & 408,3 & 0,31 & 371,3 & 52,2 \\
4 & 228,5 & 76,24 & 257,3 & 73,25 & 7,36 & 292,8 & 103,0 & 395,8 & 0,35 & 350,7 & 63,4 \\
5 & 139,3 & 85,52 & 165,7 & 82,77 & - & - & - & - & - & - & - \\
6 & 136,0 & 85,86 & 141,4 & 85,30 & - & - & - & - & - & - & - \\
8 & 156,1 & 83,77 & 179,2 & 81,37 & 6,86 & 326,3 & 83,8 & 410,1 & 0,26 & 386,2 & 33,7 \\
10 & - & - & - & - & 6,94 & 282,0 & 105,7 & 387,7 & 0,38 & 327,9 & 84,2 \\
11 & 283,7 & 70,50 & 346,6 & 63,96 & 6,81 & 300,8 & 90,4 & 391,2 & 0,30 & 342,7 & 68,4 \\
12 & 248,8 & 74,13 & 281,7 & 70,71 & - & - & - & - & - & - & - \\
13 & 169,4 & 82,39 & 185,7 & 80,69 & - & - & - & - & - & - & - \\
14 & 194,0 & 79,83 & 230,1 & 76,08 & 6,64 & 325,6 & 66,0 & 391,6 & 0,20 & 374,2 & 24,5 \\
17 & 179,3 & 81,36 & 241,0 & 74,94 & 7,02 & 327,4 & 83,8 & 411,1 & 0,26 & 390,2 & 29,5 \\
18 & 236,5 & 75,41 & 296,9 & 69,13 & - & - & - & - & - & - & - \\
20 & 188,0 & 80,45 & 259,0 & 73,07 & - & - & - & - & - & - & - \\
22 & 280,9 & 70,79 & 333,1 & 65,37 & - & - & - & - & - & - & - \\
23 & - & - & - & - & 7,09 & 379,7 & 83,8 & 463,5 & 0,22 & 450,3 & 18,6 \\
25 & 192,4 & 80,00 & 264,7 & 72,48 & - & - & - & - & - & - & - \\
26 & 304,8 & 68,31 & 336,0 & 65,07 & 7,07 & 273,6 & 106,8 & 380,4 & 0,39 & 304,9 & 106,3 \\
27 & 298,5 & 68,96 & 335,6 & 65,11 & - & - & - & - & - & - & - \\
28 & 340,4 & 64,61 & 360,2 & 62,55 & 6,88 & 249,5 & 130,2 & 379,7 & 0,52 & 298,5 & 114,3 \\
31 & 387,9 & 59,67 & 418,2 & 56,52 & 6,78 & 272,2 & 123,9 & 396,1 & 0,46 & 309,6 & 121,8 \\
33 & 292,6 & 69,58 & 346,0 & 64,03 & 7,07 & 280,9 & 107,1 & 388,1 & 0,38 & 324,3 & 89,8 \\
34 & 179,9 & 81,30 & 195,1 & 79,72 & - & - & - & - & - & - & - \\
35 & 191,9 & 80,05 & 240,0 & 75,05 & 6,94 & 319,7 & 74,0 & 393,7 & 0,23 & 376,8 & 23,8 \\
\hline
\end{tabular}


TABELA III.3 - Continuação.

\begin{tabular}{|c|c|c|c|c|c|c|c|c|c|c|c|}
\hline Dias & $\mathrm{C}_{\mathrm{EF}}$ & $\varepsilon_{\mathrm{EF}}$ & $\mathrm{C}_{\mathrm{ET}}$ & $\varepsilon_{\mathrm{ET}}$ & $\mathrm{pH}$ & AP & $\mathrm{AI}$ & AT & $\mathrm{AI} / \mathrm{AP}$ & $\mathrm{AB}$ & AVT \\
\hline 37 & 327,1 & 65,99 & 390,6 & 59,39 & - & - & - & - & - & - & - \\
\hline 38 & 281,8 & 70,70 & 346,8 & 63,94 & 7,09 & 297,3 & 125,6 & 422,8 & 0,42 & 346,8 & 107,1 \\
\hline 39 & 289,9 & 69,86 & 344,2 & 64,21 & - & - & - & - & - & - & - \\
\hline 40 & 280,9 & 70,79 & 329,5 & 65,74 & 6,95 & 306,3 & 112,7 & 419,0 & 0,37 & 355,2 & 89,9 \\
\hline 41 & 248,3 & 74,18 & 322,0 & 66,52 & 6,94 & 303,7 & 115,0 & 418,7 & 0,38 & 363,4 & 77,9 \\
\hline 42 & 201,3 & 79,07 & 277,4 & 71,16 & 6,88 & 296,9 & 129,7 & 426,6 & 0,44 & 372,9 & 75,6 \\
\hline 49 & 177,0 & 81,60 & 220,6 & 77,06 & - & - & - & - & - & - & - \\
\hline 52 & 195,9 & 79,63 & 199,2 & 79,29 & 6,98 & 306,3 & 83,6 & 389,9 & 0,27 & 366,4 & 33,2 \\
\hline 53 & 181,3 & 81,15 & 216,7 & 77,47 & 7,07 & 366,6 & 78,0 & 444,6 & 0,21 & 421,6 & 32,3 \\
\hline 54 & 364,7 & 62,08 & 413,3 & 57,03 & - & - & - & - & - & - & - \\
\hline 55 & 307,8 & 68,00 & 416,4 & 56,71 & - & - & - & - & - & - & - \\
\hline 56 & 290,8 & 69,77 & 354,1 & 63,18 & - & - & - & - & - & - & - \\
\hline 57 & 258,9 & 73,08 & 311,6 & 67,60 & - & - & - & - & - & - & - \\
\hline 59 & 287,2 & 70,14 & 317,9 & 66,95 & - & - & - & - & - & - & - \\
\hline 60 & - & - & - & - & 6,85 & 383,2 & 102,3 & 485,6 & 0,27 & 428,8 & 80,0 \\
\hline 61 & 316,6 & 67,08 & 368,4 & 61,70 & & & & & & & \\
\hline 62 & - & - & - & - & 7,23 & 377,6 & 60,2 & 437,8 & 0,16 & 414,6 & 32,7 \\
\hline 66 & 329,1 & 65,78 & 356,9 & 62,89 & - & - & - & - & - & - & - \\
\hline 67 & 303,5 & 68,44 & 372,2 & 61,30 & - & - & - & - & - & - & - \\
\hline \multicolumn{12}{|c|}{ Unidades: } \\
\hline \multicolumn{12}{|c|}{$\mathrm{C}_{\mathrm{EF}}$ e $\mathrm{C}_{\mathrm{ET}}=\mathrm{mgDQO} / \mathrm{L}$} \\
\hline \multicolumn{12}{|c|}{$\varepsilon_{\mathrm{EF}}$ e $\varepsilon_{\mathrm{EF}}=\%$} \\
\hline \multicolumn{12}{|c|}{$\mathrm{AP}, \mathrm{AI}, \mathrm{AT}$ e $\mathrm{AB}=\mathrm{mgCaCO}_{3} / \mathrm{L}$} \\
\hline & g] & $\mathrm{c} / \mathrm{L}$. & & & & & & & & & \\
\hline
\end{tabular}


TABELA III.4 - Sólidos efluentes para condição de operação com batelada de 8 h e alimentação de 1000 mgDQO/L.

\begin{tabular}{ccccc}
\hline Dias & ST & SVT & SST & SSV \\
\hline 4 & 508 & 270 & 36 & 28 \\
6 & 1080 & 272 & 48 & 14 \\
11 & 1244 & 488 & 52 & 42 \\
14 & 1768 & 976 & 24 & 6 \\
19 & 1192 & 458 & 38 & 10 \\
27 & 1434 & 416 & 64 & 50 \\
34 & 1262 & 344 & 76 & 32 \\
39 & 1474 & 550 & 76 & 36 \\
41 & 1404 & 490 & 34 & 28 \\
66 & 1174 & 228 & 30 & 28 \\
\hline Unidades: & & &
\end{tabular}

ST, SV, SST e SSV = mg/L. 


\section{(c) Operação com Alimentação de $2000 \mathrm{mgDQO} / \mathrm{L}$ e Ciclos de 8 h}

TABELA III.5 - Concentração de substrato filtrado e não filtrado $\left(\mathrm{C}_{\mathrm{EF}}\right.$ e $\left.\mathrm{C}_{\mathrm{ET}}\right)$, remoção de matéria orgânica filtrada e não filtrada $\left(\varepsilon_{\mathrm{EF}}\right.$ e $\left.\varepsilon_{\mathrm{ET}}\right), \mathrm{pH}$, alcalinidade parcial (AP), alcalinidade intermediária (AI), alcalinidade total (AT), relação entre as alcalinidades intermediária e parcial (AI/AP), alcalinidade a bicarbonato (AB) e concentração de ácidos voláteis totais (AVT) do efluente para condição de operação com batelada de 8 h e alimentação de $2000 \mathrm{mgDQO} / \mathrm{L}$.

\begin{tabular}{cccccccccccc}
\hline Dias & $\mathrm{C}_{\mathrm{EF}}$ & $\varepsilon_{\mathrm{EF}}$ & $\mathrm{C}_{\mathrm{ET}}$ & $\varepsilon_{\mathrm{ET}}$ & $\mathrm{pH}$ & $\mathrm{AP}$ & $\mathrm{AI}$ & $\mathrm{AT}$ & $\mathrm{AI} / \mathrm{AP}$ & $\mathrm{AB}$ & $\mathrm{AVT}$ \\
\hline 0 & 564,7 & 69,32 & 597,5 & 67,54 & 6,85 & 388,0 & 221,2 & 609,3 & 0,57 & 474,4 & 189,9 \\
1 & 716,4 & 61,08 & 735,9 & 60,02 & 7,06 & 492,0 & 255,7 & 747,7 & 0,52 & 492,2 & 359,9 \\
2 & 761,6 & 58,62 & 788,1 & 57,18 & 6,79 & 465,6 & 313,5 & 779,1 & 0,67 & 495,5 & 399,4 \\
3 & 735,0 & 60,07 & 769,6 & 58,19 & 7,01 & 499,8 & 300,3 & 800,1 & 0,60 & 517,2 & 398,4 \\
5 & 799,5 & 56,56 & 837,6 & 54,49 & 6,83 & 482,3 & 316,0 & 798,3 & 0,66 & 458,9 & 478,1 \\
6 & 837,3 & 54,51 & 866,9 & 52,90 & - & - & - & - & - & - & - \\
7 & 915,6 & 50,25 & 934,0 & 49,25 & 6,72 & 423,6 & 355,0 & 778,6 & 0,84 & 407,9 & 522,1 \\
8 & 716,2 & 61,09 & 824,8 & 55,19 & 6,81 & 501,2 & 306,7 & 808,0 & 0,61 & 480,6 & 461,1 \\
10 & 820,8 & 55,40 & 868,2 & 52,83 & - & - & - & - & - & - & - \\
12 & 848,2 & 53,91 & 872,0 & 52,62 & 6,85 & 411,1 & 335,0 & 746,1 & 0,81 & 424,8 & 452,5 \\
13 & 854,2 & 53,59 & 816,8 & 55,62 & 6,83 & 464,7 & 307,3 & 772,0 & 0,66 & 486,2 & 402,4 \\
14 & 847,6 & 53,95 & 888,4 & 51,73 & - & - & - & - & - & - & - \\
15 & 894,2 & 51,42 & 925,2 & 49,73 & 6,72 & 443,7 & 320,8 & 764,5 & 0,72 & 394,8 & 520,8 \\
16 & 892,4 & 51,51 & 952,2 & 48,26 & - & - & - & - & - & - & - \\
19 & 939,6 & 48,11 & 980,0 & 45,88 & 6,67 & 416,7 & 377,7 & 794,5 & 0,91 & 411,0 & 540,1 \\
\hline
\end{tabular}

Unidades:

$\mathrm{C}_{\mathrm{EF}}$ e $\mathrm{C}_{\mathrm{ET}}=\mathrm{mgDQO} / \mathrm{L}$;

$\varepsilon_{\mathrm{EF}}$ e $\varepsilon_{\mathrm{EF}}=\%$;

$\mathrm{AP}, \mathrm{AI}, \mathrm{AT}$ e $\mathrm{AB}=\mathrm{mgCaCO}_{3} / \mathrm{L}$;

$\mathrm{AVT}=\mathrm{mgHAc} / \mathrm{L}$. 
TABELA III.6 - Sólidos efluentes para condição de operação com batelada de 8 h e alimentação de 2000 mgDQO/L.

\begin{tabular}{ccccc}
\hline Dias & ST & SVT & SST & SSV \\
\hline 1 & 2196 & 512 & 88 & 34 \\
6 & 2368 & 710 & 48 & 74 \\
9 & 2220 & 734 & 50 & 44 \\
13 & 2474 & 658 & 84 & 88 \\
15 & 2536 & 666 & 86 & 48 \\
\hline
\end{tabular}

Unidades:

$\mathrm{ST}, \mathrm{SV}, \mathrm{SST}$ e SSV $=\mathrm{mg} / \mathrm{L}$ 


\section{(d) Operação com Alimentação de 2000 mgDQO/L e Ciclos de 12 h}

TABELA III.7 - Concentração de substrato filtrado e não filtrado $\left(\mathrm{C}_{\mathrm{EF}}\right.$ e $\left.\mathrm{C}_{\mathrm{ET}}\right)$, remoção de matéria orgânica filtrada e não filtrada $\left(\varepsilon_{\mathrm{EF}}\right.$ e $\left.\varepsilon_{\mathrm{ET}}\right), \mathrm{pH}$, alcalinidade parcial (AP), alcalinidade intermediária (AI), alcalinidade total (AT), relação entre as alcalinidades intermediária e parcial (AI/AP), alcalinidade a bicarbonato (AB) e concentração de ácidos voláteis totais (AVT) do efluente para condição de operação com batelada de $12 \mathrm{~h}$ e alimentação de $2000 \mathrm{mgDQO} / \mathrm{L}$.

\begin{tabular}{cccccccccccc}
\hline Dias & $\mathrm{C}_{\mathrm{EF}}$ & $\varepsilon_{\mathrm{EF}}$ & $\mathrm{C}_{\mathrm{ET}}$ & $\varepsilon_{\mathrm{ET}}$ & $\mathrm{pH}$ & $\mathrm{AP}$ & $\mathrm{AI}$ & $\mathrm{AT}$ & $\mathrm{AI} / \mathrm{AP}$ & $\mathrm{AB}$ & $\mathrm{AVT}$ \\
\hline 1 & 767,2 & 57,59 & 856,6 & 52,65 & 7,06 & 550,7 & 315,7 & 866,4 & 0,57 & 544,9 & 452,8 \\
2 & 700,2 & 61,29 & 723,6 & 60,00 & - & - & - & - & - & - & - \\
5 & 677,4 & 62,55 & 700,1 & 61,30 & 6,91 & 490,2 & 281,5 & 771,7 & 0,57 & 515,9 & 360,2 \\
6 & 638,0 & 64,73 & 670,2 & 62,95 & 6,90 & 506,0 & 278,3 & 784,3 & 0,55 & 533,3 & 353,5 \\
7 & 630,2 & 65,16 & 662,0 & 63,41 & - & - & - & - & - & - & - \\
9 & 507,0 & 71,97 & 532,2 & 70,58 & - & - & - & - & - & - & - \\
10 & 551,7 & 69,50 & 591,8 & 67,29 & - & - & - & - & - & - & - \\
11 & 547,0 & 69,76 & 562,0 & 68,93 & - & - & - & - & - & - & - \\
13 & - & - & - & - & 6,98 & 499,7 & 287,8 & 787,5 & 0,58 & 553,8 & 329,2 \\
20 & 401,7 & 77,79 & 426,3 & 76,43 & 6,99 & 540,4 & 240,2 & 780,6 & 0,44 & 614,6 & 233,9 \\
22 & 463,1 & 74,40 & 480,2 & 73,45 & 6,91 & 502,2 & 240,2 & 742,4 & 0,48 & 575,8 & 234,7 \\
25 & 353,3 & 80,47 & 387,5 & 78,58 & - & - & - & - & - & - & - \\
26 & 377,2 & 79,15 & 422,5 & 76,64 & 7,66 & 629,0 & 201,3 & 830,3 & 0,32 & 750,5 & 112,3 \\
28 & 364,7 & 79,84 & 406,0 & 77,56 & 7,11 & 650,3 & 224,3 & 874,6 & 0,34 & 808,4 & 93,2 \\
32 & 325,6 & 82,00 & 352,1 & 80,54 & - & - & - & - & - & - & - \\
33 & 322,7 & 82,16 & 368,3 & 79,64 & 7,13 & 672,8 & 209,3 & 882,1 & 0,31 & 818,9 & 89,0 \\
34 & 365,6 & 79,79 & 392,7 & 78,29 & - & - & - & - & - & - & - \\
35 & 353,1 & 80,48 & 364,6 & 79,85 & 7,10 & 633,9 & 218,3 & 852,2 & 0,34 & 793,6 & 82,5 \\
\hline Unidades: & & & & & & & & & & \\
$\mathrm{C}_{\mathrm{EF}} \mathrm{e} \mathrm{C}_{\mathrm{ET}}=$ & $\mathrm{mgDQO} / \mathrm{L} ;$ & & & & & & & & & \\
$\varepsilon_{\mathrm{EF}} \mathrm{e}$ & $\varepsilon_{\mathrm{EF}}=\% ;$ & & & & & & & & & & \\
$\mathrm{AP}, \mathrm{AI}, \mathrm{AT}$ & $\mathrm{e}$ & $\mathrm{AB}=$ & $\mathrm{mgCaCO} / \mathrm{L} ;$ & & & & & & & \\
$\mathrm{AVT}=\mathrm{mgHAc} / \mathrm{L}$. & & & & & & & & &
\end{tabular}


TABELA III.8 - Sólidos efluentes para condição de operação com batelada de 12 h e alimentação de 2000 mgDQO/L.

\begin{tabular}{ccccc}
\hline Dias & ST & SVT & SST & SSV \\
\hline 5 & 3210 & 1464 & 118 & 94 \\
7 & 3214 & 1542 & 74 & 58 \\
21 & 3144 & 1152 & - & - \\
26 & 3016 & 1362 & 54 & 34 \\
28 & 3316 & 1470 & 136 & 70 \\
33 & 3420 & 1544 & 150 & 78 \\
35 & 3306 & 1506 & 106 & 56 \\
\hline
\end{tabular}

Unidades:

$\mathrm{ST}, \mathrm{SV}, \mathrm{SST}$ e SSV = mg/L. 


\section{(e) Operação com Alimentação de 1500 mgDQO/L e Ciclos de 12 h}

TABELA III.9 - Concentração de substrato filtrado e não filtrado $\left(\mathrm{C}_{\mathrm{EF}}\right.$ e $\left.\mathrm{C}_{\mathrm{ET}}\right)$, remoção de matéria orgânica filtrada e não filtrada $\left(\varepsilon_{\mathrm{EF}}\right.$ e $\left.\varepsilon_{\mathrm{ET}}\right)$, $\mathrm{pH}$, alcalinidade parcial (AP), alcalinidade intermediária (AI), alcalinidade total (AT), relação entre as alcalinidades intermediária e parcial (AI/AP), alcalinidade a bicarbonato (AB) e concentração de ácidos voláteis totais (AVT) do efluente para condição de operação com batelada de $12 \mathrm{~h}$ e alimentação de $1500 \mathrm{mgDQO} / \mathrm{L}$.

\begin{tabular}{|c|c|c|c|c|c|c|c|c|c|c|c|}
\hline Dias & $\mathrm{C}_{\mathrm{EF}}$ & $\varepsilon_{\mathrm{EF}}$ & $\mathrm{C}_{\mathrm{ET}}$ & $\varepsilon_{\mathrm{ET}}$ & $\mathrm{pH}$ & AP & AI & AT & $\mathrm{AI} / \mathrm{AP}$ & $\mathrm{AB}$ & AVT \\
\hline 4 & 237,6 & 83,01 & 264,4 & 81,09 & 7,02 & 501,5 & 164,1 & 665,7 & 0,33 & 619,2 & 65,4 \\
\hline 5 & 243,3 & 82,60 & 268,0 & 80,83 & 6,93 & 480,2 & 167,2 & 647,4 & 0,35 & 601,9 & 64,1 \\
\hline 6 & 271,1 & 80,61 & 281,5 & 79,87 & - & - & - & - & - & - & - \\
\hline 7 & 269,5 & 80,73 & 285,7 & 79,57 & 7,07 & 471,2 & 149,3 & 620,4 & 0,32 & 574,0 & 65,4 \\
\hline 10 & 243,8 & 82,56 & 258,7 & 81,50 & 6,99 & 494,6 & 146,3 & 640,9 & 0,30 & 595,0 & 64,7 \\
\hline 11 & 265,5 & 81,01 & 276,4 & 80,23 & 6,94 & 468,2 & 161,0 & 629,2 & 0,34 & 575,7 & 75,4 \\
\hline 12 & 253,9 & 81,84 & 264,8 & 81,06 & 6,96 & 510,4 & 176,1 & 686,6 & 0,35 & 632,5 & 76,1 \\
\hline 17 & 236,4 & 83,09 & 270,5 & 80,66 & 6,99 & 505,2 & 179,4 & 684,6 & 0,36 & 637,4 & 66,4 \\
\hline 19 & 224,2 & 83,97 & 244,4 & 82,53 & 6,99 & 523,2 & 167,4 & 690,6 & 0,32 & 642,4 & 67,8 \\
\hline 20 & 203,0 & 85,48 & 225,1 & 83,90 & - & - & - & - & - & - & - \\
\hline 21 & 232,3 & 83,39 & 243,5 & 82,59 & - & - & - & - & - & - & - \\
\hline 22 & 224,8 & 83,92 & 256,4 & 81,66 & - & - & - & - & - & - & - \\
\hline 25 & - & - & - & - & 6,96 & 553,8 & 170,4 & 724,2 & 0,31 & 669,0 & 77,8 \\
\hline 26 & 262,3 & 81,24 & 289,8 & 79,27 & 6,99 & 484,3 & 185,3 & 669,6 & 0,38 & 615,3 & 76,6 \\
\hline 27 & 251,2 & 82,04 & 285,4 & 79,59 & 7,02 & 551,7 & 148,4 & 700,0 & 0,27 & 645,4 & 76,9 \\
\hline 28 & 256,2 & 81,68 & 300,5 & 78,51 & - & - & - & - & - & - & - \\
\hline 31 & 250,6 & 82,08 & 281,7 & 79,85 & 7,30 & 563,3 & 135,4 & 698,7 & 0,24 & 640,6 & 81,9 \\
\hline \multicolumn{12}{|c|}{ Unidades: } \\
\hline \multicolumn{12}{|c|}{$\mathrm{C}_{\mathrm{EF}}$ e $\mathrm{C}_{\mathrm{ET}}=\mathrm{mgDQO} / \mathrm{L} ;$} \\
\hline \multicolumn{12}{|c|}{$\varepsilon_{\mathrm{EF}}$ e $\varepsilon_{\mathrm{EF}}=\%$} \\
\hline \multicolumn{12}{|c|}{$\mathrm{AP}, \mathrm{AI}, \mathrm{AT}$ e $\mathrm{AB}=\mathrm{mgCaCO}_{3} / \mathrm{L}$} \\
\hline & & & & & & & & & & & \\
\hline
\end{tabular}


TABELA III.10 - Sólidos efluentes para condição de operação com batelada de $12 \mathrm{~h}$ e alimentação de 1500 mgDQO/L.

\begin{tabular}{ccccc}
\hline Dias & ST & SVT & SST & SSV \\
\hline 4 & 1686 & 350 & 56 & 20 \\
11 & 1712 & 424 & 50 & 26 \\
13 & 1778 & 596 & 102 & 48 \\
20 & 1192 & 302 & 36 & 32 \\
26 & 1818 & 282 & 74 & 30 \\
\hline
\end{tabular}

Unidades:

$\mathrm{ST}, \mathrm{SV}, \mathrm{SST}$ e SSV $=\mathrm{mg} / \mathrm{L}$. 
(f) Operação com Alimentação 1000mgDQO/L e Ciclos de 12 h

TABELA III.11 - Concentração de substrato filtrado e não filtrado $\left(\mathrm{C}_{\mathrm{EF}}\right.$ e $\left.\mathrm{C}_{\mathrm{ET}}\right)$, remoção de matéria orgânica filtrada e não filtrada $\left(\varepsilon_{\mathrm{EF}}\right.$ e $\left.\varepsilon_{\mathrm{ET}}\right), \mathrm{pH}$, alcalinidade parcial (AP), alcalinidade intermediária (AI), alcalinidade total (AT), relação entre as alcalinidades intermediária e parcial (AI/AP), alcalinidade a bicarbonato (AB) e concentração de ácidos voláteis totais (AVT) do efluente para condição de operação com batelada de $12 \mathrm{~h}$ e alimentação de $1000 \mathrm{mgDQO} / \mathrm{L}$.

\begin{tabular}{cccccccccccc}
\hline Dias & $\mathrm{C}_{\mathrm{EF}}$ & $\varepsilon_{\mathrm{EF}}$ & $\mathrm{C}_{\mathrm{ET}}$ & $\varepsilon_{\mathrm{ET}}$ & $\mathrm{pH}$ & $\mathrm{AP}$ & $\mathrm{AI}$ & $\mathrm{AT}$ & $\mathrm{AI} / \mathrm{AP}$ & $\mathrm{AB}$ & $\mathrm{AVT}$ \\
\hline 2 & 192,7 & 80,57 & 257,3 & 74,06 & - & - & - & - & - & - & - \\
7 & 118,6 & 88,04 & 139,5 & 85,94 & 6,90 & 386,5 & 103,1 & 489,6 & 0,27 & 464,7 & 35,2 \\
8 & 120,8 & 87,82 & 142,2 & 85,67 & - & - & - & - & - & - & - \\
9 & 117,3 & 88,18 & 141,5 & 85,74 & - & - & - & - & - & - & - \\
10 & 110,6 & 88,85 & 125,5 & 87,35 & - & - & - & - & - & - & - \\
13 & 120,0 & 87,90 & 145,7 & 85,31 & 6,95 & 352,3 & 131,3 & 483,6 & 0,37 & 461,1 & 31,7 \\
14 & 114,7 & 88,44 & 132,9 & 86,60 & - & - & - & - & - & - & - \\
15 & 107,0 & 89,21 & 124,3 & 87,47 & - & - & - & - & - & - & - \\
16 & 120,4 & 87,86 & 140,0 & 85,89 & - & - & - & - & - & - & - \\
17 & 145,0 & 85,38 & 152,3 & 84,65 & 6,90 & 368,9 & 101,6 & 470,6 & 0,28 & 448,2 & 31,5 \\
21 & 128,2 & 87,08 & 161,8 & 83,69 & - & - & - & - & - & - & - \\
22 & 128,5 & 87,05 & 145,9 & 85,29 & - & - & - & - & - & - & - \\
23 & 121,1 & 87,79 & 142,2 & 85,67 & 6,92 & 378,3 & 79,9 & 458,1 & 0,21 & 440,8 & 24,4 \\
24 & 148,1 & 85,07 & 171,0 & 82,76 & - & - & - & - & - & - & - \\
25 & 129,8 & 86,92 & 161,5 & 83,72 & - & - & - & - & - & - & - \\
26 & 122,4 & 87,66 & 143,1 & 85,57 & 6,96 & 374,0 & 84,6 & 458,6 & 0,23 & 440,5 & 25,5 \\
27 & 116,3 & 88,28 & 129,5 & 86,95 & 7,05 & 370,9 & 86,3 & 457,2 & 0,23 & 439,8 & 24,5 \\
28 & 106,8 & 89,23 & 130,8 & 86,81 & 7,18 & 375,3 & 86,3 & 461,6 & 0,23 & 445,1 & 23,2 \\
29 & 140,4 & 85,85 & 167,7 & 83,09 & 7,11 & 398,1 & 82,6 & 480,7 & 0,21 & 461,4 & 27,2 \\
30 & 125,3 & 87,37 & 139,8 & 85,91 & 7,19 & 380,5 & 73,9 & 454,4 & 0,19 & 437,5 & 23,9 \\
31 & 132,7 & 86,62 & 139,3 & 85,96 & 6,92 & 365,9 & 91,6 & 457,5 & 0,25 & 440,7 & 23,7 \\
\hline
\end{tabular}

Unidades:

$\mathrm{C}_{\mathrm{EF}}$ e $\mathrm{C}_{\mathrm{ET}}=\mathrm{mgDQO} / \mathrm{L} ; \varepsilon_{\mathrm{EF}}$ e $\varepsilon_{\mathrm{EF}}=\%$;

$\mathrm{AP}, \mathrm{AI}, \mathrm{AT}$ e $\mathrm{AB}=\mathrm{mgCaCO}_{3} / \mathrm{L} ; \mathrm{AVT}=\mathrm{mgHAc} / \mathrm{L}$. 
TABELA III.12 - Sólidos efluentes para condição de operação com batelada de $12 \mathrm{~h}$ e alimentação de 1000 mgDQO/L.

\begin{tabular}{|c|c|c|c|c|}
\hline Dias & ST & SVT & SST & SSV \\
\hline 2 & 1026 & 318 & - & - \\
\hline 7 & 1204 & 322 & 42 & 18 \\
\hline 9 & 1108 & 254 & 34 & 12 \\
\hline 14 & 1228 & 276 & 48 & - \\
\hline 16 & 1222 & 260 & - & 24 \\
\hline 23 & 1128 & 338 & 50 & 12 \\
\hline 28 & 1226 & 288 & - & 12 \\
\hline 30 & 1194 & 316 & 30 & 18 \\
\hline
\end{tabular}

Unidades:

ST, SV, SST e SSV $=\mathrm{mg} / \mathrm{L}$. 


\section{APÊNDICE IV}

\section{PERFIL AO LONGO DA BATELADA}

\section{(a) Operação com Alimentação de $500 \mathrm{mgDQO} / \mathrm{L}$ e Ciclos de 8 h.}

TABELA IV.1 - Perfil de concentração de substrato filtrado $\left(\mathrm{C}_{\mathrm{EFi}}\right)$, eficiências de remoção para o perfil $\left(\varepsilon_{\mathrm{Pi}}\right)$, concentrações de substrato corrigidas $\left(\mathrm{C}_{\mathrm{EFi}}{ }^{\prime}\right)$ e respectivas médias do efluente para condição de operação com batelada de $8 \mathrm{~h} \mathrm{e}$ alimentação de 500 mgDQO/L.

\begin{tabular}{cccccccccc}
\hline Tempo & \multicolumn{3}{c}{ Ensaio 1 } & \multicolumn{3}{c}{ Ensaio 2} & \multicolumn{3}{c}{ Média } \\
\cline { 2 - 10 }$(\mathrm{h})$ & $\mathrm{C}_{\mathrm{EF} 1}$ & $\varepsilon_{\mathrm{P} 1}$ & $\mathrm{C}^{\prime}{ }_{\mathrm{EF} 1}$ & $\mathrm{C}_{\mathrm{EF} 2}$ & ${ }{ }_{\mathrm{P} 2}$ & $\mathrm{C}^{\prime}{ }_{\mathrm{FF} 2}$ & $\mathrm{C}_{\mathrm{EF}}$ & $\varepsilon_{\mathrm{P}}$ & $\mathrm{C}^{\prime}{ }_{\mathrm{FF}}$ \\
\hline 0,00 & 387,7 & 0,0 & 373,9 & 360,0 & 0,0 & 373,9 & 373,9 & 0,0 & 373,9 \\
0,25 & 331,9 & 14,4 & 320,0 & 290,3 & 19,4 & 301,5 & 311,1 & 16,9 & 310,8 \\
0,50 & 279,4 & 27,9 & 269,4 & 240,6 & 33,2 & 249,9 & 260,0 & 30,6 & 259,6 \\
0,75 & 261,4 & 32,6 & 252,1 & 220,3 & 38,8 & 228,8 & 240,9 & 35,7 & 240,4 \\
1,00 & 229,9 & 40,7 & 221,7 & 199,3 & 44,6 & 207,0 & 214,6 & 42,7 & 214,3 \\
1,25 & 213,0 & 45,1 & 205,4 & 182,9 & 49,2 & 189,9 & 198,0 & 47,1 & 197,7 \\
1,50 & 183,2 & 52,7 & 176,7 & 169,1 & 53,0 & 175,6 & 176,2 & 52,9 & 176,1 \\
1,75 & 156,3 & 59,7 & 150,7 & 157,3 & 56,3 & 163,4 & 156,8 & 58,0 & 157,0 \\
2,00 & 150,8 & 61,1 & 145,4 & 147,9 & 58,9 & 153,6 & 149,4 & 60,0 & 149,5 \\
2,25 & 128,3 & 66,9 & 123,7 & 135,3 & 62,4 & 140,5 & 131,8 & 64,7 & 132,1 \\
2,50 & 113,5 & 70,7 & 109,4 & 131,9 & 63,4 & 137,0 & 122,7 & 67,0 & 123,2 \\
2,75 & 111,4 & 71,3 & 111,4 & 127,9 & 64,5 & 132,8 & 119,7 & 67,9 & 122,1 \\
3,00 & 106,9 & 72,4 & 106,9 & 109,1 & 69,7 & 113,3 & 108,0 & 71,1 & 110,1 \\
3,50 & 95,4 & 75,4 & 95,4 & 99,2 & 72,4 & 103,0 & 97,3 & 73,9 & 99,2 \\
4,00 & 83,8 & 78,4 & 83,8 & 84,4 & 76,6 & 87,6 & 84,1 & 77,5 & 85,7 \\
4,50 & 84,1 & 78,3 & 81,1 & 82,8 & 77,0 & 86,0 & 83,5 & 77,7 & 83,5 \\
5,00 & 77,8 & 79,9 & 75,0 & 66,7 & 81,5 & 69,3 & 72,3 & 80,7 & 72,1 \\
5,50 & 68,9 & 82,2 & 66,4 & 68,4 & 81,0 & 71,0 & 68,7 & 81,6 & 68,7 \\
\hline & & & & & & & & & Continua
\end{tabular}


TABELA IV.1 - Continuação.

\begin{tabular}{cccccccccc}
\hline Tempo & \multicolumn{3}{c}{ Ensaio 1 } & \multicolumn{3}{c}{ Ensaio 2 } & \multicolumn{3}{c}{ Média } \\
\cline { 2 - 9 }$(\mathrm{h})$ & $\mathrm{C}_{\mathrm{EF} 1}$ & $\varepsilon_{\mathrm{P} 1}$ & $\mathrm{C}^{\prime}{ }_{\mathrm{EF} 1}$ & $\mathrm{C}_{\mathrm{EF} 2}$ & $\varepsilon_{\mathrm{P} 2}$ & $\mathrm{C}_{\mathrm{EF} 2}^{\prime}$ & $\mathrm{C}_{\mathrm{EF}}$ & $\varepsilon_{\mathrm{P}}$ & $\mathrm{C}_{\mathrm{EF}}$ \\
\hline 6,00 & 79,6 & 79,5 & 76,8 & 68,9 & 80,9 & 71,6 & 74,3 & 80,2 & 74,2 \\
6,50 & 72,6 & 81,3 & 70,0 & 62,0 & 82,8 & 64,4 & 67,3 & 82,0 & 67,2 \\
7,00 & 57,8 & 85,1 & 55,7 & 71,8 & 80,1 & 74,6 & 64,8 & 82,6 & 65,1 \\
7,50 & 58,5 & 84,9 & 56,4 & 65,6 & 81,8 & 68,1 & 62,1 & 83,3 & 62,3 \\
7,60 & 67,0 & 82,7 & 64,6 & 65,4 & 81,8 & 67,9 & 66,2 & 82,3 & 66,3
\end{tabular}

Unidades:

$\mathrm{C}_{\mathrm{EFi}}, \mathrm{C}^{\prime}{ }_{\mathrm{Efi}} \mathrm{e} \mathrm{C}_{\mathrm{EF}}=\mathrm{mgDQO} / \mathrm{L}$;

$\varepsilon_{\mathrm{Pi}}$ e $\varepsilon_{\mathrm{P}}=\%$. 
TABELA IV.2 - Perfis de concentração de alcalinidade a bicarbonato (AB) e concentração de ácidos voláteis totais (AVT) ao longo do ciclo do efluente para condição de operação com batelada de 8 h e alimentação de 500 mgDQO/L.

\begin{tabular}{ccccccc}
\hline \multirow{2}{*}{$\begin{array}{c}\text { Tempo } \\
(\mathrm{h})\end{array}$} & \multicolumn{2}{c}{ Ensaio 1 } & \multicolumn{2}{c}{ Ensaio 2 } & \multicolumn{2}{c}{ Média } \\
\cline { 2 - 7 } & AB & AVT & AB & AVT & AB & AVT \\
\hline 0,0 & 149 & 28 & 152 & 23 & 150 & 25 \\
0,5 & 169 & 35 & 164 & 35 & 166 & 35 \\
1,0 & 175 & 45 & 173 & 45 & 174 & 45 \\
1,5 & 178 & 45 & 178 & 47 & 178 & 46 \\
2,0 & 189 & 44 & 185 & 47 & 187 & 45 \\
2,5 & 199 & 44 & 180 & 43 & 189 & 43 \\
3,0 & 200 & 38 & 193 & 40 & 197 & 39 \\
3,5 & 211 & 35 & 207 & 37 & 209 & 36 \\
4,0 & 215 & 25 & 212 & 36 & 213 & 31 \\
4,5 & 216 & 24 & 217 & 28 & 216 & 26 \\
5,0 & 213 & 24 & 227 & 19 & 220 & 22 \\
5,5 & 215 & 23 & 227 & 19 & 221 & 21 \\
6,0 & 216 & 23 & 216 & 19 & 216 & 21 \\
6,5 & 217 & 23 & 212 & 19 & 214 & 21 \\
7,0 & 206 & 27 & 216 & 19 & 211 & 23 \\
7,5 & 213 & 24 & 216 & 19 & 215 & 22 \\
7,6 & 208 & 27 & 215 & 19 & 212 & 23 \\
\hline
\end{tabular}

Unidades:

$\mathrm{AB}=\mathrm{mgCaCO}_{3} / \mathrm{L}$

$\mathrm{AVT}=\operatorname{mgHAc} / \mathrm{L}$. 


\section{(b) Operação com Alimentação de $1000 \mathrm{mgDQO} / \mathrm{L}$ e Ciclos de $8 \mathrm{~h}$.}

TABELA IV.3 - Perfil de concentração de substrato filtrado $\left(\mathrm{C}_{\mathrm{EFi}}\right)$, eficiências de remoção para o perfil $\left(\varepsilon_{\mathrm{Pi}}\right)$, concentrações de substrato corrigidas $\left(\mathrm{C}^{\prime}{ }_{\mathrm{EFi}}\right)$ e respectivas médias do efluente para condição de operação com batelada de $8 \mathrm{~h}$ e alimentação de $1000 \mathrm{mgDQO} / \mathrm{L}$.

\begin{tabular}{|c|c|c|c|c|c|c|c|c|c|c|c|c|}
\hline \multirow{2}{*}{$\begin{array}{c}\text { Tempo } \\
\text { (h) }\end{array}$} & \multicolumn{3}{|c|}{ Ensaio 1} & \multicolumn{3}{|c|}{ Ensaio 2} & \multicolumn{3}{|c|}{ Ensaio 3} & \multicolumn{3}{|c|}{ Média } \\
\hline & $\mathrm{C}_{\mathrm{EF} 1}$ & $\varepsilon_{\mathrm{P} 1}$ & $\mathrm{C}_{\mathrm{EF} 1}^{\prime}$ & $\mathrm{C}_{\mathrm{EF} 2}$ & $\varepsilon_{\mathrm{P} 2}$ & $\mathrm{C}^{\prime}{ }_{\mathrm{EF} 2}$ & $\mathrm{C}_{\mathrm{EF} 3}$ & $\varepsilon_{\mathrm{P} 3}$ & $\mathrm{C}^{\prime}{ }_{\mathrm{EF} 3}$ & $\mathrm{C}_{\mathrm{EF}}$ & $\varepsilon_{\mathrm{P}}$ & $\mathrm{C}^{\prime} \mathrm{SF}$ \\
\hline 0,00 & 768,5 & 0,0 & 720,9 & 715,9 & 0,0 & 720,9 & 678,3 & 0,0 & 720,9 & 720,9 & 0,0 & 720,9 \\
\hline 0,25 & 643,2 & 16,3 & 603,4 & 600,6 & 16,1 & 604,8 & 588,4 & 13,3 & 625,4 & 610,7 & 15,2 & 611,2 \\
\hline 0,50 & 554,0 & 27,9 & 519,7 & 517,8 & 27,7 & 521,4 & 534,9 & 21,1 & 568,5 & 535,6 & 25,6 & 536,5 \\
\hline 0,75 & 489,9 & 36,3 & 459,6 & 467,5 & 34,7 & 470,8 & 499,7 & 26,3 & 531,1 & 485,7 & 32,4 & 487,1 \\
\hline 1,00 & 439,2 & 42,8 & 412,0 & 434,1 & 39,4 & 437,1 & 476,2 & 29,8 & 506,1 & 449,8 & 37,3 & 451,7 \\
\hline 1,25 & 396,3 & 48,4 & 371,8 & 408,7 & 42,9 & 411,6 & 463,8 & 31,6 & 492,9 & 422,9 & 41,0 & 425,4 \\
\hline 1,50 & 383,5 & 50,1 & 359,7 & 387,6 & 45,9 & 390,3 & 479,7 & 29,3 & 509,8 & 416,9 & 41,7 & 420,0 \\
\hline 1,75 & 353,5 & 54,0 & 331,6 & 375,9 & 47,5 & 378,5 & 443,9 & 34,6 & 471,8 & 391,1 & 45,4 & 394,0 \\
\hline 2,00 & 315,6 & 58,9 & 296,1 & 361,1 & 49,6 & 363,6 & 423,1 & 37,6 & 449,7 & 366,6 & 48,7 & 369,8 \\
\hline 2,25 & 293,1 & 61,9 & 274,9 & 355,8 & 50,3 & 358,3 & 415,0 & 38,8 & 441,1 & 354,6 & 50,3 & 358,1 \\
\hline 2,50 & 266,6 & 65,3 & 250,1 & 353,2 & 50,7 & 355,7 & 405,8 & 40,2 & 431,3 & 341,9 & 52,0 & 345,7 \\
\hline 2,75 & 249,1 & 67,6 & 233,7 & 334,9 & 53,2 & 337,2 & 391,1 & 42,3 & 415,7 & 325,0 & 54,4 & 328,9 \\
\hline 3,00 & 239,0 & 68,9 & 224,2 & 326,1 & 54,4 & 328,4 & 375,1 & 44,7 & 398,7 & 313,4 & 56,0 & 317,1 \\
\hline 3,50 & 230,4 & 70,0 & 216,1 & 314,1 & 56,1 & 316,3 & 370,8 & 45,3 & 394,1 & 305,1 & 57,2 & 308,8 \\
\hline 4,00 & 222,0 & 71,1 & 208,2 & 307,0 & 57,1 & 309,1 & 354,9 & 47,7 & 377,2 & 294,6 & 58,6 & 298,2 \\
\hline 4,50 & 201,5 & 73,8 & 189,0 & 294,6 & 58,8 & 296,7 & 342,2 & 49,6 & 363,7 & 279,4 & 60,7 & 283,1 \\
\hline 5,00 & 196,0 & 74,5 & 183,9 & 286,7 & 60,0 & 288,7 & 323,3 & 52,3 & 343,6 & 268,7 & 62,3 & 272,1 \\
\hline 5,50 & 188,7 & 75,4 & 177,0 & 287,5 & 59,8 & 289,5 & 317,9 & 53,1 & 337,9 & 264,7 & 62,8 & 268,1 \\
\hline 6,00 & 189,1 & 75,4 & 177,4 & 257,3 & 64,1 & 259,1 & 301,1 & 55,6 & 320,0 & 249,2 & 65,0 & 252,2 \\
\hline 6,50 & 176,8 & 77,0 & 165,8 & 220,6 & 69,2 & 222,1 & 289,5 & 57,3 & 307,7 & 229,0 & 67,8 & 231,9 \\
\hline 7,00 & 170,3 & 77,8 & 159,8 & 202,5 & 71,7 & 203,9 & 289,5 & 57,3 & 307,7 & 220,8 & 69,0 & 223,8 \\
\hline 7,50 & 171,6 & 77,7 & 161,0 & 188,2 & 73,7 & 189,5 & 266,7 & 60,7 & 283,4 & 208,8 & 70,7 & 211,3 \\
\hline 7,60 & 195,9 & 74,5 & 183,8 & 188,2 & 73,7 & 189,5 & 260,8 & 61,6 & 277,2 & 215,0 & 69,9 & 216,8 \\
\hline
\end{tabular}


TABELA IV.4 - Perfis de concentração de alcalinidade a bicarbonato (AB) e concentração de ácidos voláteis totais (AVT) ao longo do ciclo do efluente para condição de operação com batelada de 8 h e alimentação de 1000 mgDQO/L.

\begin{tabular}{ccccccccc}
\hline Tempo & \multicolumn{2}{c}{ Ensaio 1 } & \multicolumn{2}{c}{ Ensaio 2 } & \multicolumn{2}{c}{ Ensaio 3 } & \multicolumn{2}{c}{ Média } \\
\cline { 2 - 8 }$(\mathrm{h})$ & AB & AVT & AB & AVT & AB & AVT & AB & AVT \\
\hline 0,0 & 312 & 44 & 308 & 62 & 262 & 82,10 & 294 & 62 \\
0,5 & 339 & 54 & 337 & 81 & 314 & 78,98 & 330 & 71 \\
1,0 & 359 & 47 & 334 & 104 & 325 & 82,67 & 339 & 78 \\
1,5 & 371 & 43 & 350 & 99 & 333 & 88,07 & 351 & 77 \\
2,0 & 393 & 34 & 358 & 105 & 339 & 94,32 & 363 & 78 \\
2,5 & 404 & 34 & 363 & 106 & 351 & 91,48 & 372 & 77 \\
3,0 & 405 & 33 & 381 & 99 & 363 & 90,63 & 383 & 74 \\
3,5 & 408 & 35 & 382 & 97 & 386 & 65,63 & 392 & 66 \\
4,0 & 411 & 33 & 387 & 99 & 408 & 41,48 & 402 & 58 \\
4,5 & 410 & 33 & 394 & 93 & 414 & 33,52 & 406 & 53 \\
5,0 & 419 & 32 & 402 & 90 & 419 & 29,55 & 414 & 51 \\
5,5 & 415 & 36 & 405 & 89 & 428 & 32,96 & 416 & 52 \\
6,0 & 416 & 35 & 415 & 90 & 426 & 33,24 & 419 & 53 \\
6,5 & 420 & 32 & 418 & 89 & 420 & 32,39 & 419 & 51 \\
7,0 & 418 & 34 & 428 & 83 & 412 & 34,66 & 419 & 51 \\
7,5 & 422 & 32 & 429 & 80 & 412 & 32,96 & 421 & 48 \\
7,6 & 422 & 32 & 429 & 80 & 415 & 32,67 & 422 & 48 \\
\hline
\end{tabular}

Unidades:

$\mathrm{AB}=\mathrm{mgCaCO} / \mathrm{L}$

$\mathrm{AVT}=\operatorname{mgHAc} / \mathrm{L}$. 
TABELA IV.5 - Perfil de composição do biogás ao longo do ciclo do efluente para condição de operação com batelada de 8 h e alimentação de 1000 mgDQO/L.

\begin{tabular}{ccccccc}
\hline Tempo & \multicolumn{2}{c}{ Ensaio 1} & \multicolumn{2}{c}{ Ensaio 2 } & \multicolumn{2}{c}{ Média } \\
\cline { 2 - 7 }$(\mathrm{h})$ & $\mathrm{CH}_{4}$ & $\mathrm{CO}_{2}$ & $\mathrm{CH}_{4}$ & $\mathrm{CO}_{2}$ & $\mathrm{CH}_{4}$ & $\mathrm{CO}_{2}$ \\
\hline 0,0 & 0,08 & 0,18 & 0,06 & 0,09 & 0,07 & 0,14 \\
0,5 & 1,69 & 2,71 & 1,71 & 2,62 & 1,70 & 2,67 \\
1,0 & 2,91 & 3,77 & 2,80 & 3,36 & 2,85 & 3,56 \\
1,5 & 3,78 & 4,10 & 3,74 & 3,79 & 3,76 & 3,95 \\
2,0 & 4,58 & 4,28 & 4,45 & 3,38 & 4,52 & 3,83 \\
2,5 & 5,28 & 4,38 & 5,40 & 4,45 & 5,34 & 4,41 \\
3,0 & 5,96 & 4,54 & 6,08 & 4,59 & 6,02 & 4,57 \\
3,5 & 6,49 & 4,60 & 6,61 & 4,39 & 6,55 & 4,50 \\
4,0 & 7,07 & 4,68 & 6,70 & 4,40 & 6,88 & 4,54 \\
4,5 & 7,60 & 4,75 & 7,63 & 4,19 & 7,62 & 4,47 \\
5,0 & 8,48 & 5,09 & 7,54 & 3,75 & 8,01 & 4,42 \\
5,5 & 8,55 & 4,87 & 7,94 & 3,71 & 8,25 & 4,29 \\
6,0 & 9,51 & 5,24 & 9,26 & 4,83 & 9,38 & 5,04 \\
6,5 & 9,22 & 4,85 & 9,63 & 4,94 & 9,42 & 4,89 \\
7,0 & 9,91 & 5,09 & 9,83 & 4,90 & 9,87 & 4,99 \\
7,5 & 10,21 & 5,10 & 10,13 & 5,06 & 10,17 & 5,08 \\
& & & & & &
\end{tabular}

Unidade:

$\mathrm{CH}_{4}$ e $\mathrm{CO}_{2}=\mathrm{mMol} / \mathrm{L}$. 
TABELA IV.6 - Perfil de fração molar do biogás ao longo do ciclo do efluente para condição de operação com batelada de 8 h e alimentação de 1000 mgDQO/L.

\begin{tabular}{ccccccc}
\hline Tempo & \multicolumn{2}{c}{ Ensaio 1} & \multicolumn{2}{c}{ Ensaio 2} & \multicolumn{2}{c}{ Média } \\
\cline { 2 - 7 }$(\mathrm{h})$ & $\mathrm{CH}_{4}$ & $\mathrm{CO}_{2}$ & $\mathrm{CH}_{4}$ & $\mathrm{CO}_{2}$ & $\mathrm{CH}_{4}$ & $\mathrm{CO}_{2}$ \\
\hline 0,0 & 31,0 & 69,0 & 39,5 & 60,5 & 33,9 & 66,1 \\
0,5 & 38,3 & 61,7 & 39,5 & 60,5 & 38,8 & 61,2 \\
1,0 & 43,5 & 56,5 & 45,5 & 54,5 & 44,2 & 55,8 \\
1,5 & 48,0 & 52,0 & 49,7 & 50,3 & 48,7 & 51,3 \\
2,0 & 51,7 & 48,3 & 56,8 & 43,2 & 54,0 & 46,0 \\
2,5 & 54,7 & 45,3 & 54,8 & 45,2 & 55,3 & 44,7 \\
3,0 & 56,8 & 43,2 & 57,0 & 43,0 & 57,3 & 42,7 \\
3,5 & 58,5 & 41,5 & 60,1 & 39,9 & 59,7 & 40,3 \\
4,0 & 60,1 & 39,9 & 62,4 & 37,6 & 61,5 & 38,5 \\
4,5 & 61,5 & 38,5 & 64,6 & 35,4 & 63,3 & 36,7 \\
5,0 & 62,5 & 37,5 & 66,8 & 33,2 & 64,7 & 35,3 \\
5,5 & 63,7 & 36,3 & 68,2 & 31,8 & 66,0 & 34,0 \\
6,0 & 64,5 & 35,5 & 65,7 & 34,3 & 65,6 & 34,4 \\
6,5 & 65,6 & 34,4 & 66,1 & 33,9 & 66,4 & 33,6 \\
7,0 & 66,1 & 33,9 & 66,7 & 33,3 & 67,0 & 33,0 \\
7,5 & 68,0 & 32,0 & 66,7 & 33,3 & 67,9 & 32,1 \\
\hline Unidade. & & & & & &
\end{tabular}

Unidade:

$\mathrm{CH}_{4}$ e $\mathrm{CO}_{2}=\%$, admitindo que a composição do biogás seja formada apenas por $\mathrm{CH}_{4}$ e $\mathrm{CO}_{2}$. 
(c) Operação com Alimentação de 2000 mgDQO/L e Ciclos de 8 h.

TABELA IV.7 - Perfil de concentração de substrato filtrado $\left(\mathrm{C}_{\mathrm{EF}}\right)$, eficiências de remoção para o perfil $\left(\varepsilon_{\mathrm{P}}\right)$ no perfil ao longo do ciclo para condição de operação com batelada de 8 h e alimentação de 2000 mgDQO/L.

\begin{tabular}{|c|c|c|}
\hline \multirow{2}{*}{$\begin{array}{l}\text { Tempo } \\
\text { (h) }\end{array}$} & \multicolumn{2}{|c|}{ Ensaio 1} \\
\hline & $\mathrm{C}_{\mathrm{EF}}$ & $\varepsilon_{\mathrm{P}}$ \\
\hline 0,00 & 1367,2 & 0,0 \\
\hline 0,25 & 1206,8 & 11,7 \\
\hline 0,50 & 1104,2 & 19,2 \\
\hline 0,75 & 1043,8 & 23,7 \\
\hline 1,50 & 989,6 & 27,6 \\
\hline 1,75 & 966,0 & 29,3 \\
\hline 2,00 & 954,6 & 30,2 \\
\hline 2,25 & 941,4 & 31,1 \\
\hline 2,50 & 934,0 & 31,7 \\
\hline 2,75 & 938,8 & 31,3 \\
\hline 3,00 & 915,8 & 33,0 \\
\hline 3,50 & 906,8 & 33,7 \\
\hline 4,00 & 889,2 & 35,0 \\
\hline 4,50 & 877,8 & 35,8 \\
\hline 5,00 & 861,4 & 37,0 \\
\hline 5,50 & 862,4 & 36,9 \\
\hline 6,00 & 846,6 & 38,1 \\
\hline 6,50 & 828,0 & 39,4 \\
\hline 7,00 & 833,4 & 39,0 \\
\hline 7,50 & 804,4 & 41,2 \\
\hline 7,60 & 819,6 & 40,1 \\
\hline
\end{tabular}


TABELA IV.8 - Perfis de concentração de alcalinidade a bicarbonato (AB) e concentração de ácidos voláteis totais (AVT) ao longo do ciclo para condição de operação com batelada de 8 h e alimentação de 2000 mgDQO/L.

\begin{tabular}{ccc}
\hline Tempo & & Ensaio 1 \\
\cline { 2 - 3 }$(\mathrm{h})$ & $\mathrm{AB}$ & $\mathrm{AVT}$ \\
\hline 0,00 & 528 & 101 \\
0,67 & 440 & 341 \\
1,33 & 475 & 334 \\
2,00 & 443 & 378 \\
2,67 & 425 & 357 \\
3,33 & 458 & 400 \\
4,00 & 479 & 391 \\
5,00 & 466 & 420 \\
6,00 & 477 & 427 \\
7,00 & 486 & 402 \\
7,50 & 486 & 402 \\
\hline Unidades: & & \\
$\mathrm{AB}=\mathrm{mgCaCO}_{3} / \mathrm{L} ;$ & & \\
$\mathrm{AVT}=\mathrm{mgHAc}_{\mathrm{L}}$. & &
\end{tabular}


TABELA IV.9 - Perfil de composição do biogás ao longo do ciclo para condição de operação com batelada de 8 h e alimentação de 2000 mgDQO/L.

\begin{tabular}{ccc}
\hline Tempo & \multicolumn{2}{c}{ Ensaio 1 } \\
\cline { 2 - 3 }$(\mathrm{h})$ & $\mathrm{CH}_{4}$ & $\mathrm{CO}_{2}$ \\
\hline 0,0 & 0,04 & 0,13 \\
0,5 & 1,33 & 3,57 \\
1,0 & 2,41 & 5,32 \\
1,5 & 3,26 & 5,61 \\
2,0 & 4,05 & 5,99 \\
2,5 & 4,75 & 6,15 \\
3,0 & 5,41 & 6,49 \\
3,5 & 5,89 & 6,53 \\
4,0 & 6,20 & 5,94 \\
4,5 & 6,74 & 6,24 \\
5,0 & 7,30 & 6,70 \\
5,5 & 7,66 & 6,63 \\
6,0 & 8,52 & 6,74 \\
6,5 & 8,84 & 6,89 \\
7,0 & 9,27 & 6,88 \\
7,5 & 9,53 & 6,56 \\
\hline Unidade: & & \\
$\mathrm{CH}_{4}$ e $\mathrm{CO}_{2}=\mathrm{mMol}_{\mathrm{L}}$ & \\
\end{tabular}


TABELA IV.10 - Perfil de fração molar do biogás ao longo do ciclo para condição de operação com batelada de 8 h e alimentação de 2000 mgDQO/L.

\begin{tabular}{ccc}
\hline Tempo & \multicolumn{2}{c}{ Ensaio 1 } \\
\cline { 2 - 3 }$(\mathrm{h})$ & $\mathrm{CH}_{4}$ & $\mathrm{CO}_{2}$ \\
\hline 0,0 & 25,8 & 74,2 \\
0,5 & 27,2 & 72,8 \\
1,0 & 31,2 & 68,8 \\
1,5 & 36,8 & 63,2 \\
2,0 & 40,3 & 59,7 \\
2,5 & 43,6 & 56,4 \\
3,0 & 45,5 & 54,5 \\
3,5 & 47,4 & 52,6 \\
4,0 & 51,1 & 48,9 \\
4,5 & 51,9 & 48,1 \\
5,0 & 52,2 & 47,8 \\
5,5 & 53,6 & 46,4 \\
6,0 & 55,8 & 44,2 \\
6,5 & 56,2 & 43,8 \\
7,0 & 57,4 & 42,6 \\
7,5 & 59,2 & 40,8 \\
\hline
\end{tabular}

Unidade:

$\mathrm{CH}_{4}$ e $\mathrm{CO}_{2}=\%$, admitindo que a composição do biogás seja formada apenas por $\mathrm{CH}_{4}$ e $\mathrm{CO}_{2}$. 
(d) Operação com Alimentação de 2000 mgDQO/L e Ciclos de 12 h.

TABELA IV.11 - Perfil de concentração de substrato filtrado $\left(\mathrm{C}_{\mathrm{EFi}}\right)$, eficiências de remoção para o perfil $\left(\varepsilon_{\mathrm{Pi}}\right)$, concentrações de substrato corrigidas $\left(\mathrm{C}^{\prime}{ }_{\mathrm{EFi}}\right)$ e respectivas médias do efluente para condição de operação com batelada de $12 \mathrm{~h}$ e alimentação de $2000 \mathrm{mgDQO} / \mathrm{L}$.

\begin{tabular}{|c|c|c|c|c|c|c|c|c|c|}
\hline \multirow{2}{*}{$\begin{array}{c}\text { Tempo } \\
\text { (h) }\end{array}$} & \multicolumn{3}{|c|}{ Ensaio 1} & \multicolumn{3}{|c|}{ Ensaio 2} & \multicolumn{3}{|c|}{ Média } \\
\hline & $\mathrm{C}_{\mathrm{EF} 1}$ & $\varepsilon_{\mathrm{P} 1}$ & $\mathrm{C}_{\mathrm{EF} 1}^{\prime}$ & $\mathrm{C}_{\mathrm{EF} 2}$ & $\varepsilon_{\mathrm{P} 2}$ & $\mathrm{C}_{\mathrm{EF} 2}^{\prime}$ & $\mathrm{C}_{\mathrm{EF}}$ & $\varepsilon_{\mathrm{P}}$ & $\mathrm{C}_{\mathrm{EF}}^{\prime}$ \\
\hline 0,00 & 1304,8 & 0,0 & 1298,8 & 1292,8 & 0,0 & 1298,8 & 1298,8 & 0,0 & 1298,8 \\
\hline 0,33 & 1047,4 & 19,7 & 1042,6 & 941,2 & 27,2 & 945,6 & 994,3 & 23,5 & 994,1 \\
\hline 0,66 & 906,6 & 30,5 & 902,4 & 871,0 & 32,6 & 875,0 & 888,8 & 31,6 & 888,7 \\
\hline 1,00 & 856,4 & 34,4 & 852,5 & 791,0 & 38,8 & 794,7 & 823,7 & 36,6 & 823,6 \\
\hline 1,33 & 841,6 & 35,5 & 837,7 & 781,2 & 39,6 & 784,8 & 811,4 & 37,5 & 811,3 \\
\hline 1,66 & 811,6 & 37,8 & 807,9 & 774,4 & 40,1 & 778,0 & 793,0 & 38,9 & 792,9 \\
\hline 2,00 & 791,4 & 39,3 & 787,8 & 770,6 & 40,4 & 774,2 & 781,0 & 39,9 & 781,0 \\
\hline 2,33 & 776,8 & 40,5 & 773,2 & 768,9 & 40,5 & 772,5 & 772,9 & 40,5 & 772,8 \\
\hline 2,66 & 747,6 & 42,7 & 744,2 & 736,6 & 43,0 & 740,0 & 742,1 & 42,9 & 742,1 \\
\hline 3,00 & 737,0 & 43,5 & 733,6 & 676,3 & 47,7 & 679,4 & 706,7 & 45,6 & 706,5 \\
\hline 3,50 & 722,0 & 44,7 & 718,7 & 650,8 & 49,7 & 653,8 & 686,4 & 47,2 & 686,3 \\
\hline 4,00 & 671,0 & 48,6 & 667,9 & 674,0 & 47,9 & 677,1 & 672,5 & 48,2 & 672,5 \\
\hline 4,50 & 642,8 & 50,7 & 639,8 & 579,1 & 55,2 & 581,8 & 611,0 & 53,0 & 610,8 \\
\hline 5,00 & 619,2 & 52,5 & 616,4 & 563,3 & 56,4 & 565,9 & 591,3 & 54,5 & 591,1 \\
\hline 5,50 & 581,8 & 55,4 & 579,1 & 556,1 & 57,0 & 558,7 & 569,0 & 56,2 & 568,9 \\
\hline 6,00 & 571,8 & 56,2 & 569,2 & 511,7 & 60,4 & 514,1 & 541,8 & 58,3 & 541,6 \\
\hline 7,00 & 546,0 & 58,2 & 543,5 & 482,8 & 62,7 & 485,0 & 514,4 & 60,4 & 514,3 \\
\hline 8,00 & 498,0 & 61,8 & 495,7 & 431,6 & 66,6 & 433,6 & 464,8 & 64,2 & 464,7 \\
\hline 9,00 & 448,0 & 65,7 & 445,9 & 426,3 & 67,0 & 428,3 & 437,2 & 66,3 & 437,1 \\
\hline 10,00 & 416,4 & 68,1 & 414,5 & 355,2 & 72,5 & 356,8 & 385,8 & 70,3 & 385,7 \\
\hline 11,00 & 385,8 & 70,4 & 384,0 & 280,4 & 78,3 & 281,7 & 333,1 & 74,4 & 332,9 \\
\hline 11,66 & 363,8 & 72,1 & 362,1 & 234,6 & 81,9 & 235,7 & 299,2 & 77,0 & 298,9 \\
\hline
\end{tabular}

Unidades:

$\mathrm{C}_{\mathrm{EFi}}, \mathrm{C}^{\prime}{ }_{\mathrm{Efi}}$ e $\mathrm{C}_{\mathrm{EF}}=\mathrm{mgDQO} / \mathrm{L}$;

$\varepsilon_{\mathrm{Pi}}$ e $\varepsilon_{\mathrm{P}}=\%$. 
TABELA IV.12 - Perfis de concentração de alcalinidade a bicarbonato (AB) e concentração de ácidos voláteis totais (AVT) ao longo do ciclo do efluente para condição de operação com batelada de 12 h e alimentação de 2000 mgDQO/L.

\begin{tabular}{ccccccc}
\hline Tempo & \multicolumn{2}{c}{ Ensaio 1 } & \multicolumn{2}{c}{ Ensaio 2 } & \multicolumn{2}{c}{ Média } \\
\cline { 2 - 7 }$(\mathrm{h})$ & AB & AVT & AB & AVT & AB & AVT \\
\hline 0,00 & 562 & 93 & 460 & 141 & 511,07 & 117,18 \\
0,67 & 565 & 184 & 531 & 199 & 548,14 & 191,30 \\
1,33 & 591 & 199 & 586 & 200 & 588,47 & 199,77 \\
2,00 & 643 & 179 & 604 & 202 & 623,39 & 190,59 \\
3,00 & 642 & 202 & 636 & 189 & 638,57 & 195,53 \\
4,00 & 659 & 198 & 657 & 181 & 658,03 & 189,18 \\
5,00 & 682 & 186 & 690 & 155 & 686,01 & 170,83 \\
6,50 & 730 & 161 & 711 & 136 & 720,74 & 148,24 \\
8,00 & 759 & 141 & 720 & 113 & 739,51 & 127,06 \\
9,50 & 777 & 127 & 739 & 90 & 757,77 & 108,71 \\
11,00 & 806 & 107 & 804 & 89 & 804,91 & 98,12 \\
11,67 & 808 & 93 & 819 & 89 & 813,66 & 91,06 \\
\hline
\end{tabular}

Unidades:

$\mathrm{AB}=\mathrm{mgCaCO}_{3} / \mathrm{L}$;

$\mathrm{AVT}=\operatorname{mgHAc} / \mathrm{L}$. 
TABELA IV.13 - Perfil de composição do biogás ao longo do ciclo do efluente para condição de operação com batelada de 12 h e alimentação de 2000 mgDQO/L.

\begin{tabular}{ccccccc}
\hline Tempo & \multicolumn{2}{c}{ Ensaio 1} & \multicolumn{2}{c}{ Ensaio 2} & \multicolumn{2}{c}{ Média } \\
\cline { 2 - 7 }$(\mathrm{h})$ & $\mathrm{CH}_{4}$ & $\mathrm{CO}_{2}$ & $\mathrm{CH}_{4}$ & $\mathrm{CO}_{2}$ & $\mathrm{CH}_{4}$ & $\mathrm{CO}_{2}$ \\
\hline 0,00 & 0,00 & 0,00 & 0,00 & 0,00 & 0,00 & 0,00 \\
0,50 & 0,73 & 2,60 & 1,41 & 2,85 & 1,07 & 2,72 \\
1,00 & 1,50 & 4,25 & 2,28 & 4,28 & 1,89 & 4,26 \\
1,50 & 2,70 & 4,94 & 3,22 & 5,08 & 2,96 & 5,01 \\
2,00 & 3,25 & 4,42 & 4,22 & 5,52 & 3,74 & 4,97 \\
2,50 & 4,17 & 4,47 & 5,29 & 5,76 & 4,73 & 5,11 \\
3,00 & 4,78 & 4,06 & 6,25 & 5,64 & 5,51 & 4,85 \\
3,50 & 5,93 & 4,86 & 7,13 & 6,00 & 6,53 & 5,43 \\
4,00 & 6,78 & 5,03 & 7,98 & 6,08 & 7,38 & 5,56 \\
5,00 & 7,94 & 5,00 & 9,86 & 6,24 & 8,90 & 5,62 \\
6,00 & 9,03 & 4,82 & 10,89 & 6,28 & 9,96 & 5,55 \\
7,00 & 10,16 & 5,03 & 11,89 & 6,11 & 11,03 & 5,57 \\
8,00 & 11,78 & 5,67 & 13,03 & 6,21 & 12,40 & 5,94 \\
9,00 & 13,02 & 5,98 & 13,90 & 6,39 & 13,46 & 6,18 \\
10,00 & 12,47 & 5,31 & 14,65 & 6,43 & 13,56 & 5,87 \\
11,00 & 14,01 & 6,13 & 15,01 & 6,00 & 14,51 & 6,07 \\
11,67 & 14,66 & 6,11 & 15,18 & 6,13 & 14,92 & 6,12 \\
\hline
\end{tabular}

Unidade:

$\mathrm{CH}_{4}$ e $\mathrm{CO}_{2}=\mathrm{mMol} / \mathrm{L}$. 
TABELA IV.14 - Perfil de fração molar do biogás ao longo do ciclo do efluente para condição de operação com batelada de 12 h e alimentação de 2000mgDQO/L.

\begin{tabular}{ccccccc}
\hline Tempo & \multicolumn{2}{c}{ Ensaio 1} & \multicolumn{2}{c}{ Ensaio 2} & \multicolumn{2}{c}{ Média } \\
\cline { 2 - 7 }$(\mathrm{h})$ & $\mathrm{CH}_{4}$ & $\mathrm{CO}_{2}$ & $\mathrm{CH}_{4}$ & $\mathrm{CO}_{2}$ & $\mathrm{CH}_{4}$ & $\mathrm{CO}_{2}$ \\
\hline 0,00 & 0,0 & 0,0 & 0,0 & 0,0 & 0,0 & 0,0 \\
0,50 & 22,0 & 78,0 & 33,1 & 66,9 & 28,2 & 71,8 \\
1,00 & 26,1 & 73,9 & 34,7 & 65,3 & 30,7 & 69,3 \\
1,50 & 35,4 & 64,6 & 38,8 & 61,2 & 37,2 & 62,8 \\
2,00 & 42,3 & 57,7 & 43,3 & 56,7 & 42,9 & 57,1 \\
2,50 & 48,2 & 51,8 & 47,9 & 52,1 & 48,0 & 52,0 \\
3,00 & 54,0 & 46,0 & 52,6 & 47,4 & 53,2 & 46,8 \\
3,50 & 55,0 & 45,0 & 54,3 & 45,7 & 54,6 & 45,4 \\
4,00 & 57,4 & 42,6 & 56,8 & 43,2 & 57,1 & 42,9 \\
5,00 & 61,4 & 38,6 & 61,2 & 38,8 & 61,3 & 38,7 \\
6,00 & 65,2 & 34,8 & 63,4 & 36,6 & 64,2 & 35,8 \\
7,00 & 66,9 & 33,1 & 66,0 & 34,0 & 66,4 & 33,6 \\
8,00 & 67,5 & 32,5 & 67,7 & 32,3 & 67,6 & 32,4 \\
9,00 & 68,5 & 31,5 & 68,5 & 31,5 & 68,5 & 31,5 \\
10,00 & 70,1 & 29,9 & 69,5 & 30,5 & 69,8 & 30,2 \\
11,00 & 69,6 & 30,4 & 71,4 & 28,6 & 70,5 & 29,5 \\
11,67 & 70,6 & 29,4 & 71,2 & 28,8 & 70,9 & 29,1 \\
\hline
\end{tabular}

Unidade:

$\mathrm{CH}_{4}$ e $\mathrm{CO}_{2}=\%$, admitindo que a composição do biogás seja formada apenas por $\mathrm{CH}_{4}$ e $\mathrm{CO}_{2}$. 


\section{(e) Operação com Alimentação de 1500 mgDQO/L e Ciclos de 12 h.}

TABELA IV.15 - Perfil de concentração de substrato filtrado $\left(\mathrm{C}_{\mathrm{EFi}}\right)$, eficiências de remoção para o perfil $\left(\varepsilon_{\mathrm{Pi}}\right)$, concentrações de substrato corrigidas $\left(\mathrm{C}^{\prime}{ }_{\mathrm{EFi}}\right) \mathrm{e}$ respectivas médias do efluente para condição de operação com batelada de $12 \mathrm{~h}$ e alimentação de $1500 \mathrm{mgDQO} / \mathrm{L}$.

\begin{tabular}{cccccccccc}
\hline Tempo & \multicolumn{3}{c}{ Ensaio 1 } & \multicolumn{3}{c}{ Ensaio 2} & \multicolumn{3}{c}{ Média } \\
\cline { 2 - 7 } (h) & $\mathrm{C}_{\mathrm{EF} 1}$ & $\varepsilon_{\mathrm{P} 1}$ & $\mathrm{C}^{\prime}{ }_{\mathrm{EF} 1}$ & $\mathrm{C}_{\mathrm{EF} 2}$ & ${ }{ }_{\mathrm{P} 2}$ & $\mathrm{C}^{\prime}{ }_{\mathrm{EF} 2}$ & $\mathrm{C}_{\mathrm{EF}}$ & $\varepsilon_{\mathrm{P}}$ & $\mathrm{C}^{\prime}{ }_{\mathrm{EF}}$ \\
\hline 0,00 & 989,9 & 0,0 & 1020,1 & 1050,2 & 0,0 & 1020,1 & 1020,1 & 0,0 & 1020,1 \\
0,33 & 821,7 & 17,0 & 846,7 & 833,0 & 20,7 & 809,1 & 827,4 & 18,8 & 827,9 \\
0,66 & 758,9 & 23,3 & 782,0 & 769,2 & 26,8 & 747,1 & 764,1 & 25,0 & 764,6 \\
1,00 & 710,3 & 28,2 & 731,9 & 740,2 & 29,5 & 718,9 & 725,3 & 28,9 & 725,4 \\
1,33 & 684,3 & 30,9 & 705,1 & 721,5 & 31,3 & 700,8 & 702,9 & 31,1 & 703,0 \\
1,66 & 651,6 & 34,2 & 671,4 & 663,3 & 36,8 & 644,3 & 657,5 & 35,5 & 657,9 \\
2,00 & 545,7 & 44,9 & 562,3 & 603,2 & 42,6 & 585,9 & 574,5 & 43,7 & 574,1 \\
2,33 & 626,0 & 36,8 & 645,1 & 589,9 & 43,8 & 573,0 & 608,0 & 40,3 & 609,0 \\
2,66 & 597,5 & 39,6 & 615,7 & 556,3 & 47,0 & 540,3 & 576,9 & 43,3 & 578,0 \\
3,00 & 502,5 & 49,2 & 517,8 & 530,0 & 49,5 & 514,8 & 516,3 & 49,4 & 516,3 \\
3,50 & 509,8 & 48,5 & 525,3 & 496,0 & 52,8 & 481,8 & 502,9 & 50,6 & 503,5 \\
4,00 & 478,5 & 51,7 & 493,1 & 484,7 & 53,8 & 470,8 & 481,6 & 52,8 & 481,9 \\
4,50 & 317,9 & 67,9 & 327,6 & 482,7 & 54,0 & 468,8 & 400,3 & 61,0 & 398,2 \\
5,00 & 422,2 & 57,3 & 435,1 & 451,3 & 57,0 & 438,3 & 436,8 & 57,2 & 436,7 \\
5,50 & 400,0 & 59,6 & 412,2 & 421,8 & 59,8 & 409,7 & 410,9 & 59,7 & 410,9 \\
6,00 & 444,4 & 55,1 & 457,9 & 400,3 & 61,9 & 388,8 & 422,4 & 58,5 & 423,4 \\
7,00 & 431,7 & 56,4 & 444,8 & 374,6 & 64,3 & 363,8 & 403,2 & 60,4 & 404,3 \\
8,00 & 331,2 & 66,5 & 341,3 & 343,5 & 67,3 & 333,6 & 337,4 & 66,9 & 337,5 \\
9,00 & 240,0 & 75,8 & 247,3 & 309,5 & 70,5 & 300,6 & 274,8 & 73,1 & 274,0 \\
10,00 & 260,0 & 73,7 & 267,9 & 289,0 & 72,5 & 280,7 & 274,5 & 73,1 & 274,3 \\
11,00 & 230,0 & 76,8 & 237,0 & 265,1 & 74,8 & 257,5 & 247,6 & 75,8 & 247,2 \\
11,66 & 225,4 & 77,2 & 232,3 & 256,2 & 75,6 & 248,8 & 240,8 & 76,4 & 240,6 \\
\hline
\end{tabular}

Unidades:

$\mathrm{C}_{\mathrm{EFi}}, \mathrm{C}^{\prime}{ }_{\mathrm{Efi}}$ e $\mathrm{C}_{\mathrm{EF}}=\mathrm{mgDQO} / \mathrm{L}$;

$\varepsilon_{\mathrm{Pi}}$ e $\varepsilon_{\mathrm{P}}=\%$. 
TABELA IV.16 - Perfis de concentração de alcalinidade a bicarbonato (AB) e concentração de ácidos voláteis totais (AVT) ao longo do ciclo do efluente para condição de operação com batelada de 12 h e alimentação de 1500 mgDQO/L.

\begin{tabular}{ccccccc}
\hline \multirow{2}{*}{$\begin{array}{c}\text { Tempo } \\
(\mathrm{h})\end{array}$} & \multicolumn{2}{c}{ Ensaio 1 } & \multicolumn{2}{c}{ Ensaio 2 } & \multicolumn{2}{c}{ Média } \\
\cline { 2 - 7 } & AB & AVT & AB & AVT & AB & AVT \\
\hline 0,00 & 439 & 94 & 426 & 87 & 432,51 & 90,33 \\
0,67 & 448 & 156 & 432 & 150 & 440,03 & 152,74 \\
1,33 & 464 & 180 & 445 & 173 & 454,66 & 176,49 \\
2,00 & 479 & 190 & 464 & 180 & 471,65 & 185,04 \\
3,00 & 501 & 195 & 496 & 166 & 498,34 & 180,58 \\
4,00 & 533 & 179 & 489 & 150 & 510,97 & 164,38 \\
5,00 & 558 & 160 & 539 & 149 & 548,60 & 154,41 \\
6,50 & 584 & 150 & 544 & 155 & 564,00 & 152,63 \\
8,00 & 622 & 118 & 590 & 120 & 605,76 & 119,14 \\
9,50 & 633 & 115 & 609 & 112 & 621,11 & 113,43 \\
11,00 & 658 & 96 & 619 & 107 & 638,49 & 101,42 \\
11,67 & 669 & 78 & 645 & 77 & 657,22 & 77,33 \\
\hline
\end{tabular}

Unidades:

$\mathrm{AB}=\mathrm{mgCaCO}_{3} / \mathrm{L}$;

$\mathrm{AVT}=\operatorname{mgHAc} / \mathrm{L}$. 
TABELA IV.17 - Perfil de composição do biogás ao longo do ciclo para condição de operação com batelada de 12 h e alimentação de 1500 mgDQO/L.

\begin{tabular}{ccc}
\hline Tempo & \multicolumn{2}{c}{ Ensaio 1 } \\
\cline { 2 - 3 }$(\mathrm{h})$ & $\mathrm{CH}_{4}$ & $\mathrm{CO}_{2}$ \\
\hline 0,00 & 0,00 & 0,00 \\
0,50 & 0,95 & 1,99 \\
1,00 & 1,63 & 3,36 \\
1,50 & 2,34 & 3,95 \\
2,00 & 3,13 & 4,38 \\
2,50 & 3,79 & 4,47 \\
3,00 & 4,31 & 4,22 \\
3,50 & 5,55 & 4,79 \\
4,00 & 5,95 & 4,69 \\
5,00 & 7,84 & 4,84 \\
6,00 & 8,83 & 4,61 \\
7,00 & 9,79 & 4,64 \\
8,00 & 11,48 & 5,20 \\
9,00 & 12,14 & 5,30 \\
10,00 & 12,65 & 5,20 \\
11,00 & 13,50 & 5,49 \\
11,67 & 13,50 & 5,49 \\
\hline
\end{tabular}

Unidade:

$\mathrm{CH}_{4}$ e $\mathrm{CO}_{2}=\mathrm{mMol} / \mathrm{L}$ 
TABELA IV.18 - Perfil de fração molar do biogás ao longo do ciclo para condição de operação com batelada de 12 h e alimentação de 1500 mgDQO/L.

\begin{tabular}{ccc}
\hline Tempo & \multicolumn{2}{c}{ Ensaio 1 } \\
\cline { 2 - 3 }$(\mathrm{h})$ & $\mathrm{CH}_{4}$ & $\mathrm{CO}_{2}$ \\
\hline 0,00 & 0,0 & 0,0 \\
0,50 & 32,2 & 67,8 \\
1,00 & 32,6 & 67,4 \\
1,50 & 37,2 & 62,8 \\
2,00 & 41,7 & 58,3 \\
2,50 & 45,9 & 54,1 \\
3,00 & 50,5 & 49,5 \\
3,50 & 53,7 & 46,3 \\
4,00 & 55,9 & 44,1 \\
5,00 & 61,9 & 38,1 \\
6,00 & 65,7 & 34,3 \\
7,00 & 67,8 & 32,2 \\
8,00 & 68,8 & 31,2 \\
9,00 & 69,6 & 30,4 \\
10,00 & 70,9 & 29,1 \\
11,00 & 71,1 & 28,9 \\
11,67 & 71,1 & 28,9 \\
\hline
\end{tabular}

Unidade:

$\mathrm{CH}_{4}$ e $\mathrm{CO}_{2}=\%$, admitindo que a composição do biogás seja formada apenas por $\mathrm{CH}_{4}$ e $\mathrm{CO}_{2}$. 
(f) Operação com Alimentação de 1000 mgDQO/L e Ciclos de 12 h.

TABELA IV.19 - Perfil de concentração de substrato filtrado $\left(\mathrm{C}_{\mathrm{EFi}}\right)$, eficiências de remoção para o perfil $\left(\varepsilon_{\mathrm{Pi}}\right)$, concentrações de substrato corrigidas $\left(\mathrm{C}^{\prime}{ }_{\mathrm{EFi}}\right) \mathrm{e}$ respectivas médias do efluente para condição de operação com batelada de $12 \mathrm{~h}$ e alimentação de 1000 mgDQO/L.

\begin{tabular}{cccccccccc}
\hline Tempo & \multicolumn{3}{c}{ Ensaio 1 } & \multicolumn{3}{c}{ Ensaio 2} & \multicolumn{3}{c}{ Média } \\
\cline { 2 - 9 }$(\mathrm{h})$ & $\mathrm{C}_{\mathrm{EF} 1}$ & $\varepsilon_{\mathrm{P} 1}$ & $\mathrm{C}^{\prime}{ }_{\mathrm{FF} 1}$ & $\mathrm{C}_{\mathrm{EF} 2}$ & $\varepsilon_{\mathrm{P} 2}$ & $\mathrm{C}^{\prime}{ }_{\mathrm{EF} 2}$ & $\mathrm{C}_{\mathrm{EF}}$ & $\varepsilon_{\mathrm{P}}$ & $\mathrm{C}_{\mathrm{EF}}$ \\
\hline 0,00 & 638,4 & 0,0 & 654,8 & 671,1 & 0,0 & 654,8 & 654,8 & 0,0 & 654,8 \\
0,33 & 579,3 & 9,3 & 594,1 & 580,0 & 13,6 & 565,9 & 579,7 & 11,4 & 580,0 \\
0,66 & 542,1 & 15,1 & 556,0 & 520,0 & 22,5 & 507,3 & 531,1 & 18,8 & 531,7 \\
1,00 & 518,4 & 18,8 & 531,7 & 473,3 & 29,5 & 461,8 & 495,9 & 24,1 & 496,7 \\
1,33 & 454,6 & 28,8 & 466,2 & 458,0 & 31,8 & 446,8 & 456,3 & 30,3 & 456,5 \\
1,66 & 429,2 & 32,8 & 440,2 & 422,6 & 37,0 & 412,3 & 425,9 & 34,9 & 426,2 \\
2,00 & 418,9 & 34,4 & 429,6 & 386,8 & 42,4 & 377,4 & 402,9 & 38,4 & 403,5 \\
2,33 & 378,9 & 40,6 & 388,6 & 359,0 & 46,5 & 350,3 & 369,0 & 43,6 & 369,4 \\
2,66 & 364,5 & 42,9 & 373,8 & 345,6 & 48,5 & 337,2 & 355,1 & 45,7 & 355,5 \\
3,00 & 341,2 & 46,6 & 349,9 & 337,0 & 49,8 & 328,8 & 339,1 & 48,2 & 339,4 \\
3,50 & 327,2 & 48,7 & 335,6 & 293,6 & 56,3 & 286,4 & 310,4 & 52,5 & 311,0 \\
4,00 & 297,9 & 53,3 & 305,5 & 281,4 & 58,1 & 274,5 & 289,7 & 55,7 & 290,0 \\
4,50 & 272,0 & 57,4 & 279,0 & 268,5 & 60,0 & 262,0 & 270,3 & 58,7 & 270,5 \\
5,00 & 267,1 & 58,2 & 273,9 & 262,7 & 60,9 & 256,3 & 264,9 & 59,5 & 265,1 \\
5,50 & 242,7 & 62,0 & 248,9 & 238,9 & 64,4 & 233,1 & 240,8 & 63,2 & 241,0 \\
6,00 & 222,2 & 65,2 & 227,9 & 231,8 & 65,5 & 226,2 & 227,0 & 65,3 & 227,0 \\
7,00 & 198,8 & 68,9 & 203,9 & 200,2 & 70,2 & 195,3 & 199,5 & 69,5 & 199,6 \\
8,00 & 169,5 & 73,4 & 173,8 & 160,2 & 76,1 & 156,3 & 164,9 & 74,8 & 165,1 \\
9,00 & 143,4 & 77,5 & 147,1 & 150,4 & 77,6 & 146,7 & 146,9 & 77,6 & 146,9 \\
10,00 & 130,7 & 79,5 & 134,0 & 141,4 & 78,9 & 138,0 & 136,1 & 79,2 & 136,0 \\
11,00 & 125,2 & 80,4 & 128,4 & 133,8 & 80,1 & 130,5 & 129,5 & 80,2 & 129,5 \\
11,66 & 122,4 & 80,8 & 125,5 & 126,1 & 81,2 & 123,0 & 124,3 & 81,0 & 124,3 \\
\hline
\end{tabular}

Unidades:

$\mathrm{C}_{\mathrm{EFi}}, \mathrm{C}^{\prime}{ }_{\mathrm{Efi}}$ e $\mathrm{C}_{\mathrm{EF}}=\mathrm{mgDQO} / \mathrm{L}$;

$\varepsilon_{\mathrm{Pi}}$ e $\varepsilon_{\mathrm{P}}=\%$. 
TABELA IV.20 - Perfis de concentração de alcalinidade a bicarbonato (AB) e concentração de ácidos voláteis totais (AVT) ao longo do ciclo do efluente para condição de operação com batelada de 12 h e alimentação de 1000 mgDQO/L.

\begin{tabular}{ccccccc}
\hline Tempo & \multicolumn{2}{c}{ Ensaio 1 } & \multicolumn{2}{c}{ Ensaio 2 } & \multicolumn{2}{c}{ Média } \\
\cline { 2 - 7 }$(\mathrm{h})$ & AB & AVT & AB & AVT & AB & AVT \\
\hline 0,00 & 293 & 50 & 289 & 49 & 291,16 & 49,46 \\
0,67 & 301 & 89 & 301 & 83 & 301,07 & 85,98 \\
1,33 & 315 & 98 & 319 & 92 & 317,03 & 95,22 \\
2,00 & 337 & 89 & 329 & 94 & 333,17 & 91,51 \\
3,00 & 362 & 83 & 356 & 84 & 358,71 & 83,55 \\
4,00 & 381 & 71 & 367 & 71 & 374,26 & 70,90 \\
5,00 & 402 & 59 & 391 & 61 & 396,44 & 60,26 \\
6,50 & 417 & 40 & 411 & 47 & 413,90 & 43,61 \\
8,00 & 440 & 24 & 429 & 26 & 434,22 & 25,02 \\
9,50 & 437 & 22 & 430 & 29 & 433,54 & 25,72 \\
11,00 & 444 & 21 & 441 & 26 & 442,45 & 23,74 \\
11,67 & 445 & 23 & 437 & 24 & 441,25 & 23,58 \\
\hline
\end{tabular}

Unidades:

$\mathrm{AB}=\mathrm{mgCaCO} / \mathrm{L}$;

$\mathrm{AVT}=\operatorname{mgHAc} / \mathrm{L}$. 
TABELA IV.21 - Perfil de composição do biogás ao longo do ciclo do efluente para condição de operação com batelada de 12 h e alimentação de 1000 mgDQO/L.

\begin{tabular}{ccccccc}
\hline Tempo & \multicolumn{2}{c}{ Ensaio 1} & \multicolumn{2}{c}{ Ensaio 2} & \multicolumn{2}{c}{ Média } \\
\cline { 2 - 7 }$(\mathrm{h})$ & $\mathrm{CH}_{4}$ & $\mathrm{CO}_{2}$ & $\mathrm{CH}_{4}$ & $\mathrm{CO}_{2}$ & $\mathrm{CH}_{4}$ & $\mathrm{CO}_{2}$ \\
\hline 0,00 & 0,00 & 0,00 & 0,00 & 0,00 & 0,00 & 0,00 \\
0,50 & 0,73 & 1,15 & 0,69 & 1,03 & 0,71 & 1,09 \\
1,00 & 1,03 & 2,06 & 1,03 & 1,95 & 1,03 & 2,00 \\
1,50 & 1,39 & 2,57 & 1,52 & 2,67 & 1,46 & 2,62 \\
2,00 & 1,49 & 2,86 & 1,90 & 3,04 & 1,69 & 2,95 \\
2,50 & 2,36 & 3,00 & 2,69 & 3,44 & 2,53 & 3,22 \\
3,00 & 2,97 & 3,18 & 3,30 & 3,72 & 3,13 & 3,45 \\
3,50 & 2,47 & 3,14 & 3,94 & 3,75 & 3,20 & 3,44 \\
4,00 & 4,19 & 3,27 & 4,77 & 3,98 & 4,48 & 3,63 \\
5,00 & 4,57 & 2,66 & 6,00 & 3,75 & 5,29 & 3,20 \\
6,00 & 6,13 & 3,46 & 6,98 & 3,89 & 6,56 & 3,67 \\
7,00 & 7,01 & 3,54 & 7,86 & 4,06 & 7,44 & 3,80 \\
8,00 & 7,71 & 3,66 & 8,52 & 3,99 & 8,12 & 3,83 \\
9,00 & 8,49 & 3,78 & 9,33 & 4,27 & 8,91 & 4,03 \\
10,00 & 8,97 & 3,89 & 9,54 & 4,26 & 9,26 & 4,07 \\
11,00 & 9,26 & 3,87 & 10,00 & 4,31 & 9,63 & 4,09 \\
11,67 & 9,66 & 4,04 & 10,01 & 4,29 & 9,83 & 4,16 \\
\hline
\end{tabular}

Unidade:

$\mathrm{CH}_{4}$ e $\mathrm{CO}_{2}=\mathrm{mMol} / \mathrm{L}$. 
TABELA IV.22 - Perfil de fração molar do biogás ao longo do ciclo do efluente para condição de operação com batelada de 12 h e alimentação de 1000 mgDQO/L.

\begin{tabular}{ccccccc}
\hline Tempo & \multicolumn{2}{c}{ Ensaio 1} & \multicolumn{2}{c}{ Ensaio 2} & \multicolumn{2}{c}{ Média } \\
\cline { 2 - 7 }$(\mathrm{h})$ & $\mathrm{CH}_{4}$ & $\mathrm{CO}_{2}$ & $\mathrm{CH}_{4}$ & $\mathrm{CO}_{2}$ & $\mathrm{CH}_{4}$ & $\mathrm{CO}_{2}$ \\
\hline 0,00 & 0,0 & 0,0 & 0,0 & 0,0 & 0,0 & 0,0 \\
0,50 & 38,9 & 61,1 & 40,1 & 59,9 & 39,5 & 60,5 \\
1,00 & 33,4 & 66,6 & 34,5 & 65,5 & 33,9 & 66,1 \\
1,50 & 35,2 & 64,8 & 36,3 & 63,7 & 35,8 & 64,2 \\
2,00 & 34,2 & 65,8 & 38,5 & 61,5 & 36,5 & 63,5 \\
2,50 & 44,0 & 56,0 & 43,9 & 56,1 & 44,0 & 56,0 \\
3,00 & 48,3 & 51,7 & 47,1 & 52,9 & 47,6 & 52,4 \\
3,50 & 44,0 & 56,0 & 51,2 & 48,8 & 48,2 & 51,8 \\
4,00 & 56,1 & 43,9 & 54,5 & 45,5 & 55,3 & 44,7 \\
5,00 & 63,3 & 36,7 & 61,5 & 38,5 & 62,3 & 37,7 \\
6,00 & 64,0 & 36,0 & 64,2 & 35,8 & 64,1 & 35,9 \\
7,00 & 66,4 & 33,6 & 66,0 & 34,0 & 66,2 & 33,8 \\
8,00 & 67,8 & 32,2 & 68,1 & 31,9 & 68,0 & 32,0 \\
9,00 & 69,2 & 30,8 & 68,6 & 31,4 & 68,9 & 31,1 \\
10,00 & 69,8 & 30,2 & 69,2 & 30,8 & 69,5 & 30,5 \\
11,00 & 70,5 & 29,5 & 69,9 & 30,1 & 70,2 & 29,8 \\
11,67 & 70,5 & 29,5 & 70,0 & 30,0 & 70,3 & 29,7 \\
\hline
\end{tabular}

Unidade:

$\mathrm{CH}_{4}$ e $\mathrm{CO}_{2}=\%$, admitindo que a composição do biogás seja formada apenas por $\mathrm{CH}_{4}$ e $\mathrm{CO}_{2}$. 